\section{METODOLOGI PENELITIAN PENDIDIKAN MATEMATIKA}

Emy Sohilait, S.Pd, M.Pd

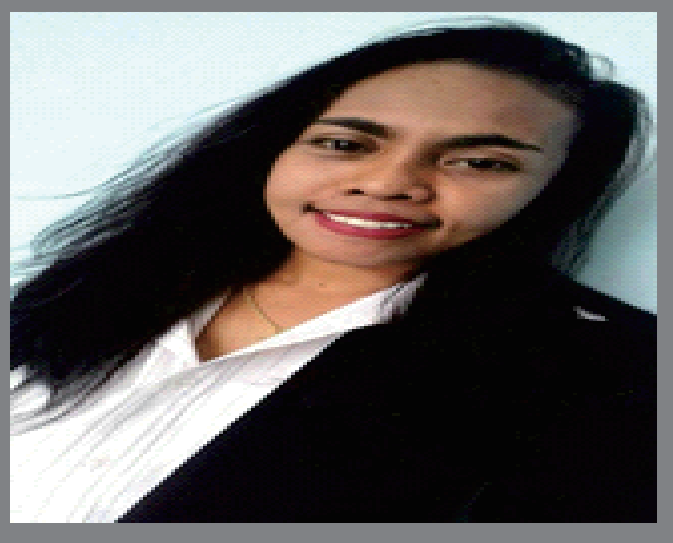

Emy Sohilait dilahirkan di Allang, 5 Juni 1990. Dari pasangan Selfina Huwae dan Reinholp Sohilait (Alm). Anak bungsu dari 5 perempuan bersaudara ini Iulusan SMA Kristen Amahai, kemudian melanjutkan pendidikan S1 dari tahun 2008-2013 di STKIP Gotong Royong Masohi Prodi Pendidikan Matematika, Sedangkah gelar Magister pendidikan matematika diperoleh pada saat

menjalani program Pascasarjana di Universitas Negeri Manado tahun 2015-2018. Tahun 2018 sampai saat ini bekerja sebagai dosen Sekolah Tinggi Keguruan dan IImu Pendidikan (STKIP) Gotong Royong Masohi pada program studi Pendidikan Matematika. Mata kuliah yang di asuh salah satunya adalah Metodologi Penelitian Pendidikan. Selain menjadi dosen juga mengikuti seminar pendidikan dan aktif menulis berbagai artikel ilmiah terkait dengan Pembelajaran Matematika Realistik. Tulisan yang pernah dibuat yaitu Development of Learning Devices on Subject the Set Through Realistic Mathematics Education, Desain Pembelajaran Berbasis Pendidikan Matematika Realistik dengan Mengunakan Masalah Kontekstual. Buku ajar Metodologi Penelitian Pendidikan Matematika merupakan buku pertama yang ditulis. Dengan harapan mahasiswa tidak ketergantungan dengan metode penelitian konvensional tetapi dapat mengikuti perkembangan trend penelitian pendidikan masa kini.
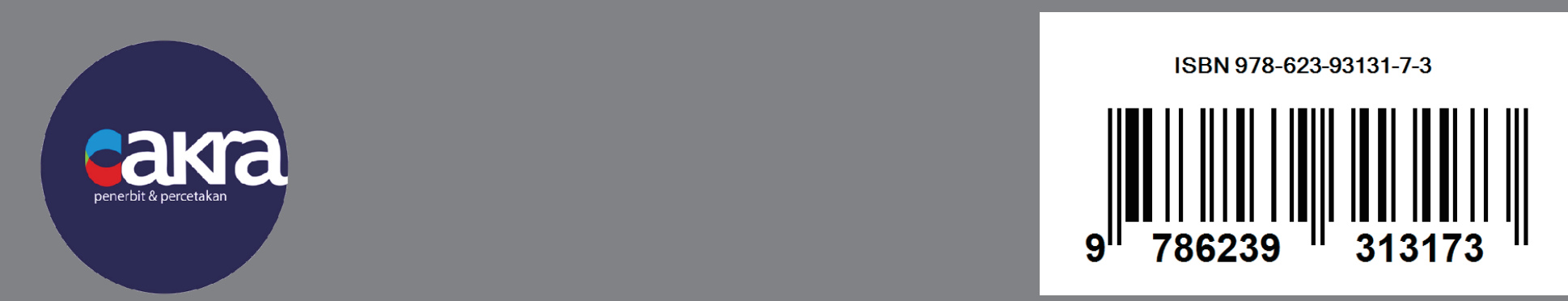

Emy Sohilait, S.Pd, M.Pd

METODOLOGI PENELITIAN PENIDIDIKAN MATEMATIKA

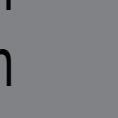


METODOLOGI PENELITIAN PENDIDIKAN MATEMATIKA 
Emy Sohilait,S.Pd.,M.Pd

\section{METODOLOGI PENELITIAN PENDIDIKAN MATEMATIKA}

\section{caka}

PENERBIT CAKRA 
(c) 2020

METODOLOGI PENELITIAN PENDIDIKAN MATEMATIKA Emy Sohilait,S.Pd.,M.Pd

Copyright @2020 All right reserved

Cetak pertama

September 2020

Diterbitkan Oleh: CV.Cakra

KANTOR BOJONG MALAKA INDAH D4 NO 90

Percetakan jalan jati mekar No.01 Telp./Faks. 022-85934522_081221122.073 Whatsapp : 082115826983 penerbit.cakra@gmail.com cakrabooks90@yahoo.com www.cakraoffset.co.id
Hak cipta dilindungi

oleh undang-undang

Dilarang memperbanyak

Sebagian atau seluruh isi buku ini

Dalam bentuk apapun

Tanpa izin dari penerbit.

Katalog dalam terbitan

METODOLOGI PENELITIAN

PENDIDIKAN MATEMATIKA

Emy Sohilait,S.Pd.,M.Pd

-Ed. I. -Cet, 1

-Bandung : Penerbit Cakra 2020

1 jil., xx + 249 hlm.: $15 \mathrm{~cm}$ x $23 \mathrm{~cm}$

ANGGOTA IKAPI

ISBN 978-623-93131-7-3 


\section{KATA PENGANTAR}

Berdasarkan pengalaman dalam mengajar metodologi penelitian pendidikan, membimbing dan menguji mahasiswa tingkat akhir; penulis melihat hampir sebagian besar penguasaan dibidang metodologi masih rendah. Hal ini mudah dipahami karena penguasaan metodologi penelitian pendidikan tidak cukup hanya dengan mendapatkan kuliah satu semester untuk mahasiswa. Memahami metodologi penelitian dan dapat mengaplikasikannya dalam meneliti masalah memerlukan pembelajaran yang lama dan latihan yang cukup banyak. Disamping itu, penguasaan metodologi penelitian pendidikan memerlukan banyak referensi yang relevan (prasyarat) dengan bidang ilmu lain seperti satistika, evaluasi pembelajaran matematika, dan media pembelajaran.

Titik berat pada buku ajar ini ialah membahas komponen-komponen penelitian juga mengkaji secara mendalam tentang jenis penelitian dan pengembangan, jenis penelitian desain riset pembelajaran masih dianggap baru dalam dunia penelitian pendidikan serta dilengkapi dengan aktivitas berpikir guna merangsang kemampuan berpikir mahasiswa, soal latihan dan tugas guna mengembangkan konsep mahasiswa lebih luas dan mendalam. Diharapkan mahasiswa dapat memahami jenis penelitian dan menemukan solusi untuk masalah yang mereka temukan di sekolah.

Ucapan terimakasih penulis sampaikan kepada semua pihak yang telah membantu sehinggu buku ajar ini dapat diselesaikan tepat pada waktunya.

Penulis juga menyadari masih banyak kelemahan dalam buku ini, oleh karena itu penulis terus membuka diri untuk menerima masukan dan kritik untuk perbaikan buku ini. Semoga ide-ide yang ada dalam buku ini dapat menambah wawasan pembaca, khususnya para mahasiswa yang sedang mengambil mata kuliah metodologi penelitian pendidikan dan sedang dalam proses penulisan proposal.

Masohi, 04 September 2020

Emy Sohilait, S.Pd., M. Pd 


\section{KATA SAMBUTAN \\ Kepala LLDIKTI Wilayah XII Ambon}

Puji dan Syukur patut dipersembahkan ke hadirat Tuhan Yang Maha Esa atas rahmat dan karuniaNya sehingga di Tahun Anggaran 2020 Penerbitan Buku Ajar dapat dilaksanakan.

Buku Ajar sebanyak 50 judul diperoleh melalui beberapa tahapan yaitu Coaching bagi para dosen, Seleksi, Evaluasi, dan Penerbitan. Keempat tahapan ini didanai oleh DIPA LLDIKTI Wilayah XII Tahun Anggaran 2020. Lima puluh judul Buku Ajar yang lolos seleksi kemudian dievaluasi dan diterbitkan per judul sebanyak seratus eksemplar.

Kegiatan Coaching, Seleksi, Evaluasi, dan Penerbitan Buku Ajar merupakan rangkaian kegiatan dari Program Peningkatan Kapasitas Tenaga Pendidik dan Kependidikan dimaksudkan untuk meningkatkan motivasi dan membudayakan menulis bagi dosen.

Buku Ajar yang diterbitkan telah disesuaikan dengan kebutuhan pembelajaran saat ini, sehingga dapat berkompetisi di era disrupsi teknologi dan juga di era Pandemik COVID-19.

Disadari bahwa minat dan budaya menulis bagi dosen di LLDIKTI Wilayah XII Ambon masih rendah jika dibandingkan dengan jumlah mata kuliah yang berada di setiap semester dan jumlah dosen yang hampir mendekati 2.000 orang yang terdiri dari Dosen PNS Dpk dan Dosen Tetap Yayasan. Namun demikian, bila dibandingkan dengan tahun sebelumnya maka terjadi peningkatan dalam tahapan Seleksi Buku Ajar. Tahun 2020 jumlah dosen yang mengikuti Seleksi Buku Ajar sebanyak 71 dosen dari 26 PTS dengan jumlah judul Buku Ajar sebanyak 82 judul. Tahun 2019 tahapan Seleksi Buku Ajar diikuti oleh 17 dosen dengan jumlah judul Buku Ajar sebanyak 19 judul. Pada tahun 2020 LLDIKTI Wilayah XII Ambon hanya dialokasikan anggaran oleh Kementerian Pendidikan Dan Kebudayaan untuk membiayai sebanyak 50 judul Buku Ajar.

Ucapan terima kasih patut dihaturkan bagi Tim Seleksi Buku Ajar dari Universitas Pattimura, masing-masing Prof. Dr. T.G. Ratumanan, M.Pd., Prof. Dr. F. Leiwakabessy, M.Pd., Prof. Dr. A. Watloly, M.Hum., dan Prof. Dr. Ali Awan, 
M.Kes. yang telah memberikan pendampingan, penilaian, dan evaluasi sesuai persyaratan penulisan Buku Ajar Perguruan Tinggi. Melalui penerbitan Buku Ajar ini diharapkan dapat meningkatkan dan mengembangkan "budaya menulis" bagi dosen, yang berdampak kepada peningkatan publikasi ilmiah dan peningkatan Akreditasi Program Studi dan Institusi.

Semoga bermanfaat.

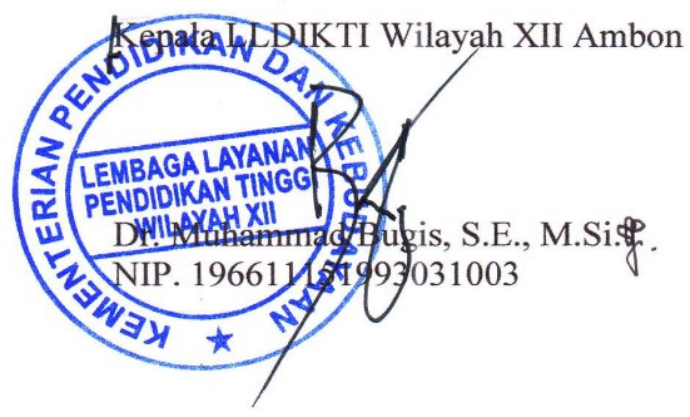




\section{DAFTAR ISI}

TINJAUAN MATAKULIAH .............................................................................ii

KATA PENGANTAR..............................................................................................iii

DAFTAR ISI _...........................................................................................

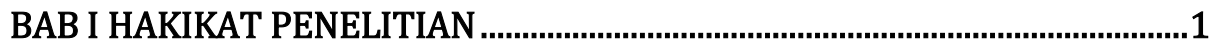

A. Hubungan Antara Ilmu Dan Pengetahuan .................................................1

B. Penelitian Pendidikan .............................................................................................. 4

C. Ruang Lingkup Penelitian Pendidikan.............................................................5

D. Keterbatasan Penelitian Pendidikan ...........................................................6

E. Fungsi Penelitian Pendidikan ......................................................................

F. Manfaat Penelitian Pendidikan .....................................................................

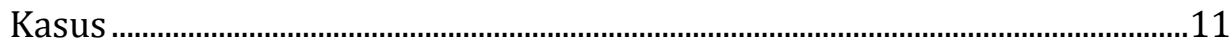

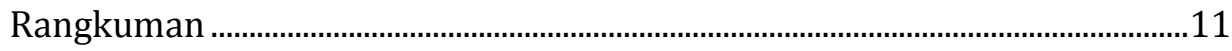

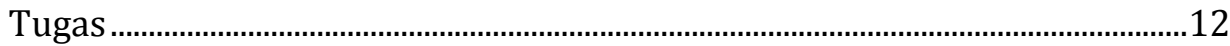

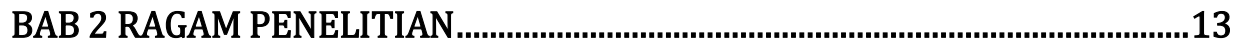

A. Jenis Penelitian Berdasarkan Pendekatan ...............................................13

1. Penelitian Kuantitatif.....................................................................................13

2. Penelitian Kualitatif..................................................................................15

B. Perbedaan Penelitian Kuantitatif Dan Kualitatif ......................................18

C. Jenis Penelitian Berdasarkan Sifat Permasalahan ...................................20

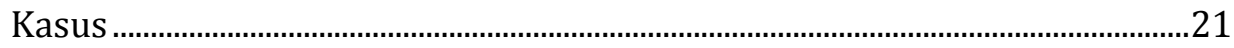

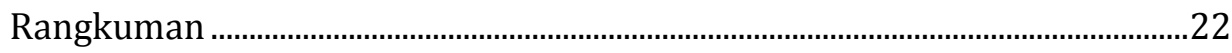

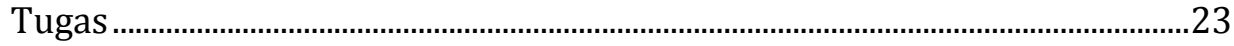


A. Sumber Masalah …………………………………………............................24

B. Kriteria Pemilihan Masalah..............................................................................28

C. Rumusan Masalah.............................................................................................

1. Rumusan masalah deskriptif ................................................................31

2. Rumusan masalah komparatif ................................................................32

3. Rumusan masalah asosiatif ....................................................................33

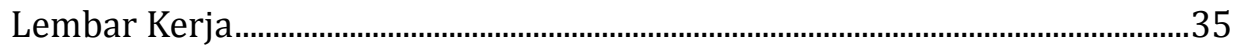

D. Rumusan Tujuan Penelitian.........................................................................36

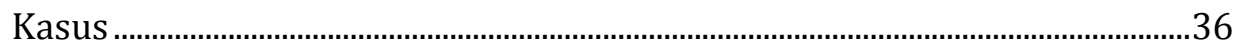

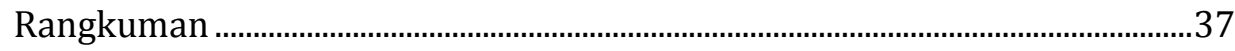

Tugas ……..................................................................................................................38

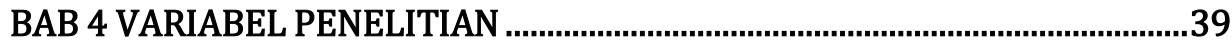

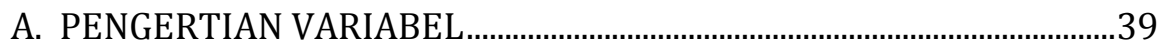

B. HUBUNGAN ANTAR VARIABEL .................................................................4

1. Hubungan simetris...................................................................................... 40

2. Hubungan timbal balik ........................................................................ 41

3. Hubungan tidak simetris.....................................................................4

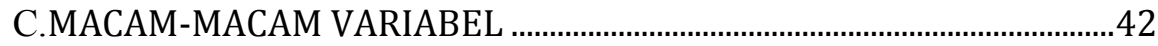

1. Variabel independen ................................................................................ 42

2. Variabel dependen ..................................................................................... 42

3. Variabel kontrol.................................................................................. 42

4. Variabel intervening …………………………………………………....4

D.PARADIGMA PENELITIAN .............................................................................. 44

Lembar Kerja........................................................................................................4

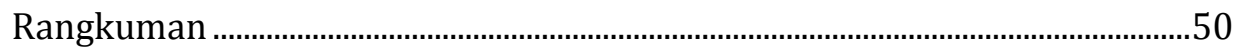

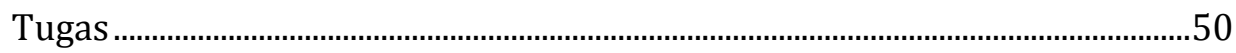




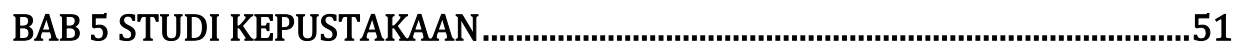

A. LANDASAN TEORI .................................................................................. 51

1. Kegunaan teori dalam penelitian....................................................53

2. Deskripsi teori ……………………………………………………….... 54

B. Kerankga Berpikir .................................................................................... 55

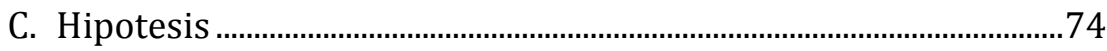

1. Hipotesis deskriptif ...........................................................................77

2. Hipotesis komparatif ..........................................................................79

3. Hipotesis asosiatif......................................................................... 80

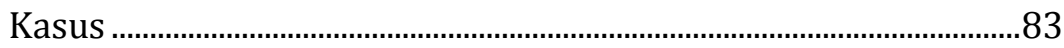

D. Paradigma Penelitian, Rumusan Masalah,

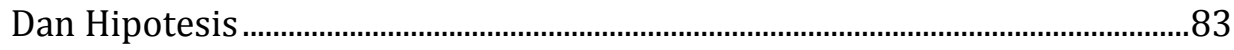

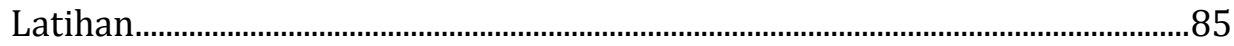

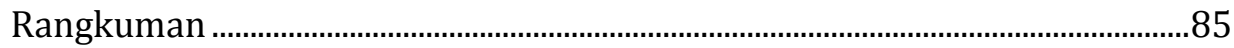

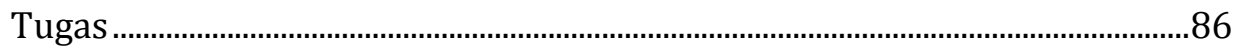

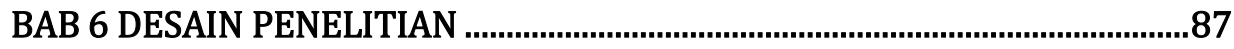

A. Dasar Dan Komponen Desain Penelitian...............................................87

B. Desain Eksperimen ....................................................................................... 88

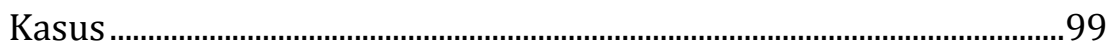

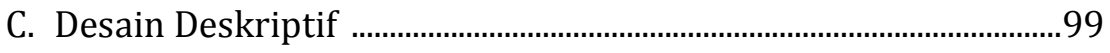

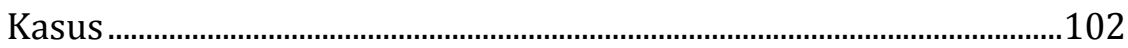

D. Design Research.........................................................................................106

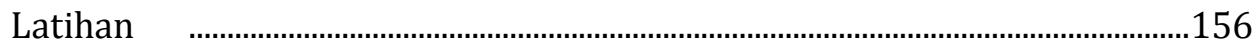

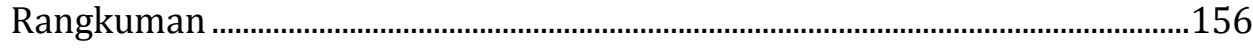

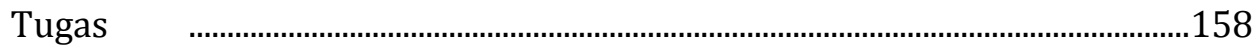


BAB 7 SUBYEK PENELITIAN. 159

A. POPULASI DAN SAMPEL …………………………………………........159

B. TEKNIK SAMPLING …………………………...............................164

C. UKURAN SAMPEL …………………………………….....................173

D. PENETAPAN UKURAN SAMPEL .......................................................174

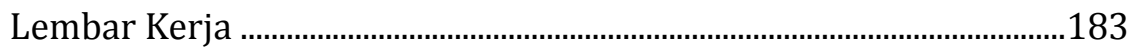

Rangkuman ................................................................................................ 183

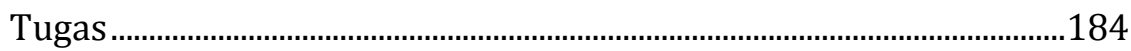

BAB 8 TEKNIK PENGUMPULAN DAN PENGUKURAN DATA .............................185

A. TEKNIK PENGUMPULAN DATA.............................................................185

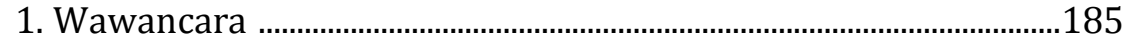

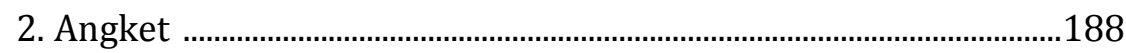

3. Observasi ....................................................................................................... 191

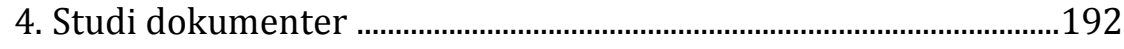

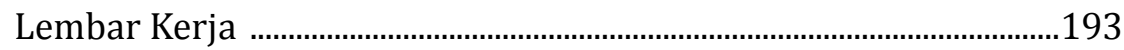

B. MACAM-MACAM SKALA PENGUKURAN ……………...........................193

1. Skala Likert................................................................................................194

2. Skala Thrustone

3. Skala Guttman …………………………………………………………...... 195

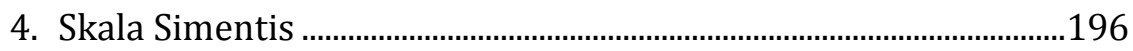

5. Skala Rating ...............................................................................................

C. TEKNIK PENGUKURAN …………………………………………….......197

D. VALIDITAS DAN RELIABILITAS INSTRUMEN ………………............199

Lembar Kerja .............................................................................................201

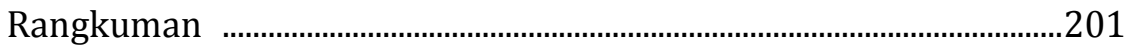

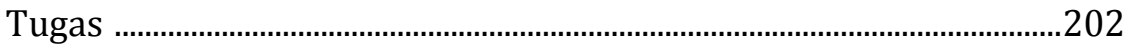




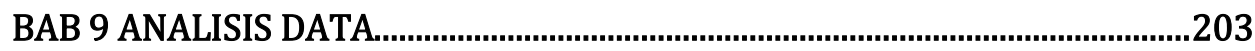

A. PENGANTAR STATISTIKA........................................................................203

B. STATISTIK DESKRIPTIF .......................................................................204

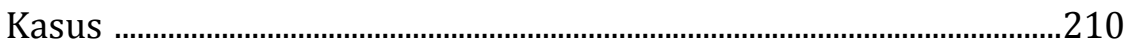

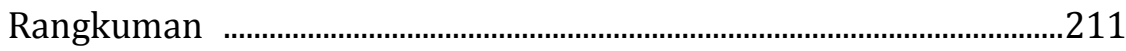

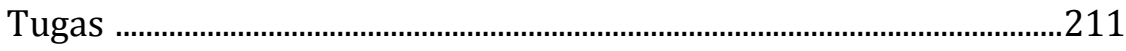

BAB 10 MENYUSUN PROPOSAL PENELITIAN ..................................................212

A. PROPOSAL PENELITIAN KUALITATI....................................................212

B. PROPOSAL PENELITIAN KUANTITATIF ..............................................220

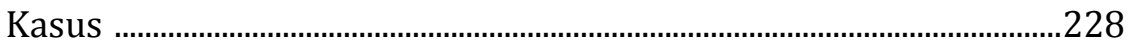

Rangkuman ............................................................................................... 231

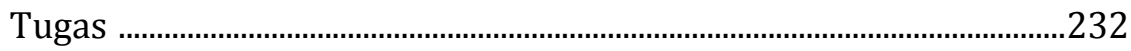

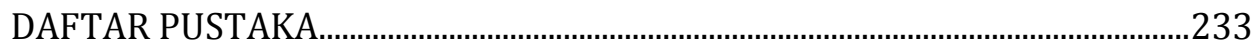

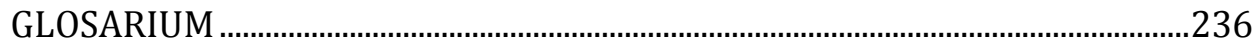




\section{BAB 1 \\ HAKIKAT PENELITIAN PENDIDIKAN}

0 alah satu cara untuk memperoleh ilmu atau pengetahuan adalah dengan penelitian. Ilmu dan penelitian adalah proses yang sama, sedangkan hasil dari proses tersebut adalah kebenaran. Penelitian dan ilmu pengetahuan telah lama menjadi bagian penting dan utama dalam meningkatkan kehidupan manusia. Khusus dibidang pendidikan, penelitian telah memberikan sumbangan terhadap pengetahuan dibidang pendidikan dengan selalu mempedomani etika. Selain itu, ulasan terhadap penemuan dan hasil-hasil penelitian telah memberikan implikasi praktis terhadap pembuatan keputusan. Pada bab ini akan dibicarakan tentang ilmu dan pengetahuan, karakteristik penelitian pendidikan, keterbatasan penelitian pendidikan, serta dungsi dan manfaat penelitian pendidikan. Kemampuan akhir yang diharapkan setelah mahasiswa mempelajari bab ini yaitu:

1. Menghubungkan keterkaitan antara ilmu dengan penelitian

2. Menjelaskan karakteristik dan ruang lingkup penelitian pendidikan

3. Menemukan keterbatasan penelitian pendidikan

4. Menyimpulkan fungsi dan manfaat penelitian pendidikan

\section{A. HUBUNGAN ANTARA ILMU DAN PENELITIAN}

Peranan ilmu dalam kehidupan manusia tidak dapat disangsikan lagi. Walaupun tidak semua orang berkecimpung dalam pengembangan ilmu, tetapi pemahaman tentang keberadaan ilmu mungkin diperlukan bagi penuntut dan pengguna ilmu, sehingga manusia tidak menaksir-naksir ilmu; juga tidak mencampuradukkan dan menjadikan ilmu berbenturan dengan pengetahuan lainnya. Bagi pengembang ilmu, mengenai keberadaan ilmu dapat menghindarkan mereka dari penyebarluasan pengetahuan yang tidak benar.

Ilmu (science) berasal dari bahasa Latin "scientia" yang berarti pengetahuan, adalah suatu metode pendekatan terhadap keseluruhan dunia empiris, yakni dunia kenyataan yang dapat dikenal manusia melalui pengalamannya. Ilmu merupakan pengetahuan yang didapat berdasarkan kajian yang berhubungan dengan fakta atau kebenaran yang tersusun secara sistematis. Ilmu pengetahuan tidak bertujuan untuk menemukan kebenaran mutlak, namun ia bersifat tentatif atau sementara yang dapat berubah bila ditemukan data baru. Tujuan ilmu pengetahuan yang sebenarnya adalah untuk memahami dunia ini. Untuk melihat keseluruhan dunia kenyataan, ilmu pengetahuan membentuk teori-teori yang dapat memberi pegangan untuk memahami dunia sekitar. Teori memberi orientasi atau arah kepada 
penelitian, sehingga membatasi fakta-fakta yang harus dipelajari dari dunia kenyataan luas. Atau dengan kata lain, teori dapat membantu menentukan fakta-fakta mana yang relevan bagi suatu penelitian.

Istilah penelitian berasal dari bahasa Inggris yaitu re-search, artinya mencari kembali. Definisi penelitian menurut Kamus Besar Bahasa Indonesia (KBBI) adalah kegiatan pengumpulan, pengolahan, analisis, dan penyajian data yang dilakukan secara sistematis dan objektif untuk memecahkan suatu persoalan atau menguji suatu hipotesis untuk mengembangkan prinsip-prinsip baru yang bertujuan untuk mendapatkan pengertian baru dan menaikkan tingkat ilmu serta teknologi. Dahulu, apabila mendengar kata "penelitian", orang sering membayangkan suatu kesibukan di laboratorium. Serorang ahli yang sedang asik mengamati reaksi zat-zat yang dicampur di tabung reaksi, atau dalam labu didih, tabung Erlenmeyer, atau alat-alat lain yang serba rumit.

Memang apa yang dibayangkan orang-orang seperti disebutkan di atas ada betulnya, tetapi tidak seluruhnya betul. Orang-orang dilaboratorium memang sedang melaksanakan penelitian, penyelidikan di bidang ilmu pengetahuan alam. Akan tetapi penelitian bukan hanya boleh dan dapat dilakukan di bidang seluruh bidang ilmu.

Namun demikian, masih banyak orang terpelajar yang beranggapan bahwa meneliti adalah tugas para ahli, profesor, doktor. Sangat disayangkan apabila anggapan semacam itu merembes ke mahasiswa. Pada waktu belum ada ekuivalen tesis atau skripsi, mahasiswa masih serius mempelajari metodologi penelitian karena akan merupakan bekal untuk mengadakan penelitian dalam rangka penulisan skripsi atau tesisnya. Setelah mereka diperbolehkan mengambil ekuivalen skripsi atau tesis, lalu beranggapan bahwa ilmu tentang penelitian tidak diperlukan lagi. Mereka lupa atau mungkin belum menyadari bahwa siapa pun boleh meneliti, karena hanya dengan penelitian maka ilmu dapat dikembangkan secara ilmiah. Misalnya:

1. Seorang ahli masak membuat kue dengan bahan sekian ons terigu, sekian butir telur, sekian ons gula pasir, sekian ons mentega, dan bahan-bahan lain. Setelah melalui proses pembuatan, kemudian diperoleh sebuah kue yang lezat. Ahli masak tersebut tidak puas dengan hasil pekerjaannya itu. Ia selalu berpikir mencari akal bagaimana agar diperoleh kue yang lebih enak lagi dengan bahanbahan yang jumlahnya sama, atau mungkin dengan bahan yang lebih sedikit sehingga biayanya lebih murah. Ahli masak ini sebenarnya juga sedang mengadakan penelitian. Tetapi tidak 
melalui prosedur yang jelas, dan tidak melaporkan hasilnya dalam bentuk tulisan.

2. Seorang guru yang mempunyai tugas mendidik dan mengajar. Ia membantu siswa. Ia selalu berusaha agar kadar bantuannya dapat meningkat sehingga diperoleh hasil yang lebih baik. Usahanya ada bermacam-macam. Mungkin ia mengganti metode yang ia gunakan untuk menerangkan. Mungkin membuat alat peraga dan sebagainya.

Dari kedua contoh di atas dapat ditarik suatu kesimpulan bahwa siapa saja yang ingin meningkatkan hasil untuk apa yang sedang ditekuni, membutuhkan kegiatan penelitian. Penelitian berarti penyelidikan yang terorganisasi untuk mengubah kesimpulan-kesimpulan yang telah diterima, ataupun mengubah dalil-dalil dengan adanya aplikasi baru dari dalil-dalil tersebut. Penyelidikan yang terorganisasi adalah suatu proses pengumpulan yang sistematis dan analisis yang logis terhadap informasi atau data untuk tujuan tertentu. Penelitian juga merupakan percobaan yang hati-hati dan kritis untuk menemukan sesuatu yang baru.

Terdapat suatu kesamaan derajat antara konsep ilmu dan penelitian. Kedua-duanya adalah sama-sama proses. Hasil dari proses tersebut adalah kebenaran. Dalam ilmu-ilmu empiris terdapat 3 teori kebenaran, yaitu teori kebenaran koherensi, korespondensi, dan pragmatisme. Berdasarkan teori kebenaran koherensi, suatu pernyataan dianggap benar jika pernyataan itu bersifat koheren (konsisten) dengan pernyataan sebelumnya yang dianggap benar. Misalnya bila kita menganggap bahwa pernyataan "semua hewan akan mati" adalah suatu pernyataan yang benar, maka pernyataan "bahwa ayam adalah hewan, dan ayam akan mati" adalah benar pula, sebab pernyataan kedua adalah konsisten dengan pernyataan yang pertama. Teori korespondensi menghasilkan kebenaran jika materi pengetahuan yang dikandung dalam pernyataan itu berkoresponden (berhubungan) dengan objek yang dituju oleh pernyataan tersebut. Teori ini digunakan dalam proses pembuktian secara empiris dalam bentuk pengumpulan fakta-fakta yang mendukung pernyataan tersebut. Misalnya jika seorang mahasiswa mengatakan "matahari terbit dari timur" maka pernyataan itu adalah benar sebab pernyataan tersebut bersifat faktual, atau sesuai dengan fakta yang ada bahwa matahari terbit dari timur dan tenggelam di sebelah barat. Dalam teori pragmatis, suatu pernyataan dianggap benar kalau pernyataan atau konsekuensi dari pernyataan itu mempunyai kegunaan praktis bagi kehidupan manusia. Jika seseorang menyatakan teori $\mathrm{X}$ dalam pendidikan, lalu dari teori 
itu dikembangkan teori Y dalam meningkatkan kemampuan belajar, maka teori $\mathrm{X}$ dianggap benar karena fungsional.

Kebenaran yang diperoleh melalui penelitian ditemukan melalui proses ilmiah. Pada masa lalu, ilmu pengetahuan tentang pendidikan terutama didasarkan pada otoritas yang dikembangkan dari pengalaman pribadi maupun observasi terhadap orang lain, sehingga bersifat subyektif dan khusus. Maka pada perkembangan selanjutnya digunakan penelitian sebagai sumber pengetahuan yang dianggap lebih terpecaya dan obyektif, karena pengetahuan yang diperoleh didasarkan fakta yang reliabel dan valid. Proses ilmiah (Hasnunidah, 2017) meliputi:

\section{1) Perumusan masalah}

Perumusan masalah merupakan pertanyaan mengenai objek empiris yang jelas batas-batasnya dan faktor-faktor yang terkait di dalamnya dapat diidentifikasi.

\section{2) Penyusunan kerangka pemikiran}

Penyusunan kerangka pemikiran merupakan argumentasi yang menjelaskan hubungan yang mungkin terdapat antar berbagai faktor yang saling mengait dan membentuk konsistensi permasalahan.

\section{3) Perumusan hipotesis}

Perumusan hipotesis merupakan jawaban sementara atau dugaan jawaban pertanyaan yang diajukan yang materinya merupakan kesimpulan dari kerangka pemikiran yang dikembangkan.

\section{4) Pengujian hipotesis}

Pengujian hipotesis merupakan pengumpulan data yang relevan dengan hipotesis yang diajukan untuk memperlihatkan apakah terdapat fakta-fakta yang mendukung hipotesis atau tidak.

\section{5) Penarikan kesimpulan}

Penarikan kesimpulan merupakan penilaian apakah hipotesis yang diajukan ditolak atau diterima. Hipotesis yang diterima lalu dianggap menjadi bagian dari pengetahuan ilmiah sebab telah memenuhi persyaratan keilmuan yakni mempunyai kerangka penjelasan yang konsisten dengan pengetahuan ilmiah sebelumnya dan telah teruji kebenarannya.

\section{B. PENELITIAN PENDIDIKAN}

Penelitian adalah penerapan pendekatan ilmiah pada pengkajian suatu masalah. Tujuannya yaitu untuk menemukan jawaban terhadap persoalan yang signifikan, melalui penerapan prosedur-prosedur ilmiah. Jika pendekatan 
ilmiah diterapkan untuk menyelidiki masalah-masalah pendidikan, maka hasilnya adalah penelitian pendidikan. Pendidikan dapat dilihat dari objek kajian interdisiplin (McMilla dan Schumacher, 1989) banyak meminjam konsep dan teori bidang ilmu lain seperti psikologi, sosiologi, antropologi, politik, dan ekonomi. Metode yang digunakan dalam penelitian pendidikan juga mengacu pada metodologi yang lazim digunakan di berbagai bidang ilmu tersebut, yakni pendekatan behavioral science. Berbagai konsep seperti intelegensi, peran, status, norma, konsep diri, keefektifan biaya juga dikaji dalan penelitian pendidikan dengan menggunakan pendekatan tersebut. Apakah yang dimaksud dengan penelitian pendidikan? Penelitian pendidikan adalah kegiatan ilmiah untuk memahami beragam masalah pendidikan dan fenomena yang ada di dunia pendidikan. Fenomena merujuk pada masalah yang muncul dalam sistem pendidikan formal, nonformal, maupun informal. Masalah ini dapat muncul dalam berbagai bentuk. Hampir setiap aspek dari ketiga sistem pendidikan tersebut mempunyai peluang untuk muncul menjadi masalah yang layak diteliti. Beberapa conoh yang mencerminkan hal tersebut adalah penelitian tentang tingkat putus sekolah, minat dan motivasi belajar, hasil belajar, prestasi belajar, kemampuan matematis, perangkat pembelajaran yang digunakan guru dan sebagainya. Tujuannya adalah menemukan prinsipprinsip umum, atau penafsiran tingkah laku yang dapat dipakai untuk menerangkan, meramalkan dan mengendalikan kejadian-kejadian dalam lingkungan pendidikan.

\section{RUANG LINGKUP PENELITIAN PENDIDIKAN}

Ruang lingkup penelitian luas sekali karena pendidikan sendiri merupakan bidang kajian yang terkait erat dengan beberapa disiplin ilmu lain seperti psikologi, sosiologi, antropologi, politik, dan ekonomi. Banyak sekali konsep atau teori pendidikan yang dikembangkan dengan mendapatkan inspirasi atau berlandaskan berbagai bidang ilmu tersebut. Contoh dalam hal ini adalah pengkajian konsep intelegensia, pengembangan sumber daya manusia (SDM), difusi, otoritas, efektivitas biaya, konsep diri, dan budaya dalam praktik dilapangan.

Penelitian pendidikan semula berorientasi pada pendekatan behavioristik. Hal ini tampak jelas dari pengaruh disiplin ilmu psikologi yang digunakan untuk uji pengukuran berbagai aspek belajar-mengajar. Meskipun demikian, akhir-akhir ini tampak ada kecenderungan bahwa penelitian pendidikan menoleh pada pendekatan lain yang digunakan dalam ilmu sosial. Pendekatan seperti observasi-partisipasif dalam antropologi serta analisis ekonomi 
pendidikan merupakan beberapa contoh yang menunjukan adanya kecenderungan tersebut.

Penggunaan berbagai konsep dan pendekatan dari berbagai disiplin ilmu memperkaya khasanah penelitian pendidikan. Hal tersebut membuka kemungkinan satu aspek pendidikan dikaji dari berbagai pendekatan yang berbeda sehingga peluang untuk mendapatkan gambaran yang lebih utuh semakin terbuka lebar. Salah satu contoh mengenai hal ini adalah kajian dalam pendidikan matematika. Kajian bidang tersebut dapat dilakukan dengan pendekatan survei kebutuhan atau kelayakan kurikulum yang akan digunakan, pendekatan observasi langsung terhadap interaksi antara guru dan siswa di kelas, pendekatan eksperimental mengenai efek berbagai jenis bahan ajar, metode pembelajaran terhadap hasil atau prestasi belajar, menghasilkan produk atau perangkat pembelajaran dengan metode penelitian pengembangan guna meningkatkan kualitas pembelajaran serta menguji coba desain pembelajaran untuk menghasilkan menghasilkan teori instruksi lokal.

\section{KETERBATASAN PENELITIAN PENDIDIKAN}

Meskipun ruang lingkup penelitian sangat luas, dalam beberapa hal penelitian pendidikan mempunyai keterbatasan yang perlu disadari oleh peneliti. Beberapa keterbatasan tersebut merupakan konsekuensi dari kompleksitas masalah dan metodologi yang bersumber dari subjek penelitian pendidikan itu sendiri, yakni manusia.

Kompleksitas masalah pendidikan merupakan pembatas karena fenomena yang muncul dalam penelitian pendidikan merupakan dampak interaksi antar pelaku yang ada dalam dunia pendidikan itu sendiri (dalam hal ini adalah orang tua, siswa, guru, dan masyarakat). Penelitian terhadap individu pelaku tersebut akan tidak bermakna apabila mereka tidak dilihat dalam perspektif konteks kehidupan nyata. Mereka merupakan para pelaku yang secara aktif merespons secara bebas (namun berbeda) terhadap stimul yang ada di sekitarnya. Dengan demikian, fenomena atau masalah yang muncul di permukaan dunia pendidikan sangat kompleks.

Penelitian pendidikan, dalam banyak hal, juga telah menunjukkan bahwa respons perilaku para pelaku terhadap stimulus di sekitarnya tidak selalu dapat diprediksi. Hal ini perlu disadari terutama oleh peneliti pendidikan pemula bahwa ketika meneliti objek kajianatau fenomena pendidikan yang tunggal pun ia harus mempertimbangkan pengaruh dan interaksi yang simultan dari berbagai variabel yang beragam, kompleks, dan kadang bersifat ambigu. Artinya, peneliti perlu menyadari bahwa ia tidak hanya berhubungan 
elemen manusia tapi dengan berbagai elemen situasional yang tak terhitung jumlahnya.

Keterbatasan kedua dalam penelitian pendidikan adalah metodologi yang digunakan. Fenomena yang dikaji dalam dunia pendidikan melibatkan pengukuran karakteristik manusia yang berhubungan dengan cara pemecahan masalah yang menggunakan ketrampilan berpikir sebagai pokok kajian. Metode yang digunakan untuk pengukuran tersebut tidak mudah karena konsep yang diukur (misalnya intelegensi, prestasi, gaya kepemimpinan, kelompok interaktif) masih dapat diperdebatkan. Sebagai dampaknya, validitas dan kredibilitas alat ukur atau metode tersebut merupakan isu yang masih menonjol. Dalam penelitian pendidikan, suatu alat ukur atau instrumen sering kali dikatakan valid dan reliabel hanya pada saat instrumen tersebut dibuat. Karena keterbatasan metodologi ini, beberapa penelitian pendidikan bahkan kadang harus ditunda karena alat ukur yang valid masih belum tersedia.

\section{E. FUNGSI PENELITIAN PENDIDIKAN}

Fungsi penelitian pendidikan dapat dilihat dari dua sudut pandang, yakni sudut perkembangan teori dan sudut praktik atau penyelenggaraan pendidikan. Dari sudut pandang teori, kegiatan penelitian itu sendiri sebenarnya tak lebih dari proses akumulasi temuan atau teori baru. Jika teori tersebut dipetakan dan ditempatkan dalam perspektif kronologis atau historis maka tampak bahwa beragam teori tersebut ada yang saling dukung atau saling bertentangan. Khasanah ilmu pendidikan memang semakin bertambah dan teori pendidikan itu sendiri berkembang lebih baik. Berkembang lebih baik berarti teori tersebut lebih mampu menjelaskan fenomena yang muncul dalam dunia pendidikan. Dengan demikian, dalam perspektif penelitian untuk penelitian, fungsi penelitian pendidikan adalah memperbaiki, menyempurnakan, memperkaya, atau kadang merombak teori yang sudah ada sehingga kita mendapatkan teori yang lebih baik.

Bagaimana fungsi tersebut dipandang dari sudut praktik atau penyelenggaraan pendidikan? Jika kita tahu bahwa dalam dimensi teori tujuan penelitian pendidikan adalah memperbaiki teori maka logis jika kita mengharapkan jawaban yang sama dari tujuan penelitian terhadap praktik pendidikan: memperbaiki praktik pendidikan. Memang itu jawabannya. Namun, perlu diperhatikan bahwa sebenarnya jawaban tersebut terkadang menimbulkan pertanyaan baru: Bagaimana? Apa dapat dipraktikkan? Berikut ini suatu ilustrasi bahwa memahami fungsi pendidikan dipandang darisudut praktik pendidikan tidak mudah. Misalnya, suatu temuan penelitian 
pendidikan menunjukkan bahwa siswa yang diberi pujian ternyata menunjukkan prestasi yang lebih baik dibanding yang tidak diberi pujian. Nah, apakah implikasi dari temuan ini bisa memperbaiki praktik pendidikan? Bagaimana? Apakah para pimpinan sekolah harus menganjurkan pada para guru agar lebih banyak memberikan pujian pada siswanya? Apakah teori tersebut dapat menjelaskan dengan tuntas sehingga para guru memahami mengapa para siswa yang mendapat banyak pujian lebih berprestasi dibanding siswa yang tidak mendapat banyak pujian?

Mc Millan dan Schumacher (1983) mengatakan bahwa memahami fungsi penelitian pendidikan dalam dimensi teori maupun praktik sebenarnya dapat dipermudah jika kita mengkaji fungsi dari jenis atau tipe penelitian itu sendiri. Mereka mengklasifikasikan tiga tipe penelitian yang mempunyai fungsi yang berbeda satu sama lain yakni penelitian dasar, terapan, dan evaluasi. Perbedaan di antara ketiga tipe tersebut dapat dilihat dari sudut topik, tujuan, tingkat generalisasi, dan kegunaan. Jika ditampilkan dalam bentuk matriks, kurang lebih tampak seperti pada tabel berikut.

Tabel 1.2. Perbedaan Karakteristik Beberapa Tipe Penelitian

\begin{tabular}{|c|l|l|l|}
\hline \multirow{2}{*}{ Aspek } & \multicolumn{3}{|c|}{ Penelitian } \\
\cline { 2 - 4 } & \multicolumn{1}{|c|}{ Dasar } & \multicolumn{1}{|c|}{ Terapan } & \multicolumn{1}{c|}{ Evaluasi } \\
\hline \multirow{2}{*}{ Topik } & $\begin{array}{l}\text { Ilmu alam, sosial, } \\
\text { behavioral }\end{array}$ & $\begin{array}{l}\text { Bidang terapan; } \\
\text { kedokteran; } \\
\text { mesin; } \\
\text { pendidikan }\end{array}$ & $\begin{array}{l}\text { Praktik/penerappan } \\
\text { pada daerah/lokasi } \\
\text { tertentu }\end{array}$ \\
\hline \multirow{2}{*}{ Tujuan } & $\begin{array}{l}\text { Menguji teori, } \\
\text { hukum sains, dan } \\
\text { prinsip-prinsip } \\
\text { dasar }\end{array}$ & $\begin{array}{l}\text { Menguji } \\
\text { kegunaan teori } \\
\text { ilmiah di masing- } \\
\text { masing bidang } \\
\text { terapan }\end{array}$ & $\begin{array}{l}\text { Mengkaji nilai } \\
\text { instrinsik suatu } \\
\text { teori yang telah } \\
\text { dipraktikkan }\end{array}$ \\
\cline { 2 - 4 } & $\begin{array}{l}\text { Menemukan } \\
\text { hubungan empiris } \\
\text { antara berbagai } \\
\text { fenomena dan } \\
\text { melakukan } \\
\text { generalisasi } \\
\text { analisis }\end{array}$ & $\begin{array}{l}\text { Menemukan } \\
\text { hubungan } \\
\text { empiris antara } \\
\text { berbagai } \\
\text { fenomena dan } \\
\text { melakukan } \\
\text { generalisasi } \\
\text { analisis di bidang }\end{array}$ & $\begin{array}{l}\text { Mengkaji nilai } \\
\text { praktis suatu teori } \\
\text { yang dipraktikan }\end{array}$ \\
\cline { 2 - 4 } & & \\
\cline { 2 - 4 } & &
\end{tabular}




\begin{tabular}{|c|c|c|c|}
\hline & & $\begin{array}{l}\text { terapan masing- } \\
\text { masing }\end{array}$ & \\
\hline \multirow[t]{2}{*}{$\begin{array}{l}\text { Tingkat } \\
\text { Generalisasi }\end{array}$} & \multirow[t]{2}{*}{$\begin{array}{l}\text { Abstrak, berkaitan } \\
\text { dengan sains }\end{array}$} & \multirow[t]{2}{*}{$\begin{array}{l}\text { Umum, berkaitan } \\
\text { dengan bidang } \\
\text { terapan }\end{array}$} & $\begin{array}{l}\text { Konkret, bersifat } \\
\text { spesifik dan erat } \\
\text { pada bidang } \\
\text { terapan yang diteliti }\end{array}$ \\
\hline & & & $\begin{array}{l}\text { Berlaku spesifik } \\
\text { pada praktik yang } \\
\text { dilakukan di lokasi } \\
\text { tertentu }\end{array}$ \\
\hline \multirow[t]{3}{*}{ Kegunaan } & $\begin{array}{l}\text { Menambah } \\
\text { perbendaharaan } \\
\text { hukum dan } \\
\text { prinsip-prinsip } \\
\text { dasar }\end{array}$ & $\begin{array}{l}\text { Menambah } \\
\text { pengetahuan } \\
\text { berbasis riset di } \\
\text { bidang terapan } \\
\text { masing-masing } \\
\end{array}$ & $\begin{array}{l}\text { Menambah } \\
\text { pengetahuan } \\
\text { berbasis riset } \\
\text { tentang nilai-nilai } \\
\text { yang terkandung }\end{array}$ \\
\hline & \multirow{2}{*}{$\begin{array}{l}\text { Mendorong untuk } \\
\text { melakukan } \\
\text { penelitian yang } \\
\text { lebih mendalam } \\
\text { dalam } \\
\text { menemukan } \\
\text { metodologi tepat }\end{array}$} & \multirow{2}{*}{$\begin{array}{l}\text { Mendorong } \\
\text { melakukan } \\
\text { penelitian yang } \\
\text { lebih mendalam } \\
\text { dan menemukan } \\
\text { metodologi tepat } \\
\text { di bidang terapan } \\
\text { (misal } \\
\text { Pendidikan) }\end{array}$} & $\begin{array}{l}\text { Dalam bidang } \\
\text { terapan tertentu } \\
\text { (misal Pendidikan) } \\
\text { di lokasi tertentu }\end{array}$ \\
\hline & & & $\begin{array}{l}\text { Mendorong ke } \\
\text { penelitian yang } \\
\text { lebih mendalam dan } \\
\text { menemukan } \\
\text { metodologi yang } \\
\text { tepat }\end{array}$ \\
\hline
\end{tabular}

(Sukmadinata, 2012)

Berdasarkan tabel di atas dapat dilihat bahwa fungsi penelitian pendidikan lebih tergambar pada aspek tujuan dan kegunaan. Meskipun demikian, perlu kita sadari bahwa suatu penelitian tidak selalu masuk ke dalam tiga kategori tersebut secara hitam putih. Artinya, kadang tidak murni penelitian dasar, terapan, atau evaluatif.

\section{F. MANFAAT PENELITIAN PENDIDIKAN}

Dua pendekatan dapat digunakan untuk mengetahui manfaat penelitian pendidikan: pendekatan teoretis (di atas kertas) dan pendekatan pengkajian terhadap publikasi kontribusi penelitian pendidikan itu sendiri terhadap dunia pendidikan. Melalui pendekatan teoretis, kita dapat melihat manfaat penelitian yang merupakan konsekuensi logis dari rangkaian kegiatan penelitian 
pendidikan. Untuk itu tentu perlu digunakan asumsi yang layak, misalnya, pengembangan sistem pendidikan memerlukan perencanaan yang masak dan teliti. Jika asumsi ini dipenuhi maka akan tampak bahwa penelitian pendidikan mempunyai manfaat yang sangat besar.

Perencanaan pendidikan berkepentingan dengan upaya memanfaatkan atau mengorganisasikan seluruh sumber daya pendidikan yang ada untuk meningkatkan kualitas pendidikan baik dari segi sistem maupun seluruh aspek penyelenggaraan pendidikan itu sendiri. Dalam hal ini, manfaat penelitian pendidikan adalah memberikan masukan atau gambaran yang sebenarnya tentang ketersediaan sumber daya pendidikan tersebut beserta hal lain yang terkait. Dengan menempatkan masyarakat sebagai konsumen pendidikan, informasi tentang hambatan ekologis, sosial, psikologis, maupun ekonomi masyarakat dapat diperoleh melalui kegiatan penelitian pendidikan. Jika informasi tersebut akurat maka perencanaan pendidikan itu akan lebih realistis.

(Muhammad, 1982) menyebutkan paling tidak ada empat manfaat hasil penelitian pendidikan sebagai berikut.

1. Sebagai peta yang menggambarkan keadaan pendidikan dan melukiskan kemampuan sumber daya, kemungkinan pengembangan serta hambatan yang dihadapi atau mungkin ditemukan dalam penyelenggaraan pendidikan.

2. Sebagai sarana diagnosis dalam mencari sebab kegagalan serta masalah yang dihadapi dalam pelaksanaan pendidikan sehingga dapat dicari upaya penanggulangannya.

3. Sebagai sarana untuk menyusun kebijakan dalam menyusun strategi pengembangan pendidikan.

4. Sebagai masukan yang memberikan gambaran tentang kemampuan dalam pembiayaan, peralatan, perbekalan, serta tenaga kerja baik yang secara kuantitas maupun kualitas sangat berperan bagi keberhasilan dalam bidang pendidikan.

Dengan demikian manfaat dari penelitian secara umum yaitu memberikan peta tentang keadaan pendidikan, menemukan solusi sebab masalah yang dihadapi serta dapat memberikan gambaran terkait tenaga pendidik secara kuantitas maupun kualitas bagi keberhasilan dalam bidang pendidikan. 


\section{KASUS}

Riset dalam pendidikan

Mahasiswa mengkaji berbagai pandangan tentang pendidikan, aspek yang terkait, permasalahan dan pendekatan dalam penelitian atau metode kerja yang diterapkan untuk pengembangan ilmu pendidikan. Berikutnya coba jawab pertanyaan-pertanyaan berikut ini.

1. Apa yang menjadi obyek material ilmu pendidikan?

2. Apa yang menjadi obyek formal ilmu pendidikan:
a.
b.
c.
d.
e.

3. Rumusan masalah pendidikan berdasarkan bidang-bidang khusus dari batang tubuh ilmu pendidikan.
a.
b.
c.
d.
e.

\section{RANGKUMAN}

Tujuan ilmu pengetahuan yang sebenarnya adalah untuk memahami dunia ini. Untuk melihat keseluruhan dunia kenyataan, ilmu pengetahuan membentuk teori-teori yang dapat memberi pegangan untuk memahami dunia sekitar. Teori memberi orientasi atau arah kepada penelitian, sehingga membatasi fakta-fakta yang harus dipelajari dari dunia kenyataan luas. Atau dengan kata lain, teori dapat membantu menentukan fakta-fakta mana yang relevan bagi suatu penelitian. Penelitian adalah penerapan pendekatan ilmiah pada pengkajian suatu masalah. Tujuannya yaitu untuk menemukan jawaban terhadap persoalan yang signifikan, melalui penerapan prosedur-prosedur ilmiah. Jika pendekatan ilmiah diterapkan untuk menyelidiki masalah-masalah pendidikan, maka hasilnya adalah penelitian pendidikan. Sebelum melakukan penelitian pendidikan, penting sekali untuk mengetahui bagaimana sikap kita sendiri terhadap nilai atau manfaat penelitian pendidikan. Selain memiliki manfaat, penelitian pendidikan juga memiliki fungsi dari dua sudut pandang, yakni sudut perkembangan teori dan sudut praktik atau penyelenggaraan pendidikan. Meskipun ruang lingkup penelitian sangat luas, dalam beberapa hal penelitian pendidikan mempunyai keterbatasan yang perlu disadari oleh 
peneliti. Beberapa keterbatasan tersebut merupakan konsekuensi dari kompleksitas masalah dan metodologi yang bersumber dari subjek penelitian pendidikan itu sendiri, yakni manusia.

TUGAS

Uraikan secara jelas analisis Anda mengenai: keterbatasan pendidikan dalam hal: pertimbangan etika dan peraturan dalam kaitannya dengan penelitian yang melibatkan manusia, lembaga kemasyarakatan, kompleksitas masalah, dan masalah metodologis. Buatlah dalam bentuk makalah dengan bagian pokok yang harus ada adalah Pendahuluan, Isi, dan Kesimpulan. 


\section{BAB 2 \\ RAGAM PENELITIAN}

emua penelitian mempunyai tujuan utama yang sama, yaitu untuk memperoleh pengetahuan yang berdasarkan bukti-bukti empiris. Namun demikian, karena bentuk dan coraknya bermacam-macam maka penelitian dapat diklasifikasikan berdasarkan tinjauan yang berbeda. Penelitian dapat dibedakan berdasarkan pendekatan yang digunakan dalam penelitiannya. Selain itu, penelitian juga dapat dilihat dari penggunaannya dan sifat permasalahannya. Masyarakat pada umumnya, juga para peneliti seringkali menilai dan menghargai masing-masing jenis penelitian tersebut secara berbeda. Mereka mempertentangkan dan menganggap bahwa salah satu jenis lebih baik daripada yang lain. Padahal masing-masing mempunyai kelebihan dan kekurangan yang tidak dimiliki oleh yang lain, sehingga hanya cocok dan diperlukan untuk tujuan dan situasi tertentu. Pada bab ini akan dibicarakan tentang jenis-jenis penelitian berdasarkan pendekatan, dan sifat permasalahannya. Kemampuan akhir yang diharapkan setelah mahasiswa mempelajari bab ini yaitu:

1. Menerangkan perbedaan di antara berbagai penelitian berdasarkan sifat permasalahannya

2. Memberikan contoh jenis penelitian berdasarkan sifat permasalahannya

3. Mengkategorikan ragam penelitian berdasarkan jenis pendekatan yang digunakan

\section{A. JENIS PENELITIAN BERDASARKAN PENDEKATAN}

Berdasarkan klasifikasi ini, maka penelitian dibagi menjadi dua, yaitu: kuantitatif dan kualitatif.

\section{Penelitian kuantitatif}

Ontologi penelitian kuantitatif berpandangan bahwa realitas itu tunggal yang bisa dipisahkan dan dapat diteliti sendiri. Logika yang digunakan adalah logika positivistik dan menghindari sifat-sifat subjektif. Pola pikir yang digunakan adalah pola pikir deduktif yang berusaha untuk memahami suatu fenomena dengan cara menggunakan konsep-konsep yang bersifat umum, yang abstrak untuk mencari hal-hal yang bersifat khusus dari fenomena yang diteliti. Contoh Teori: logam ketika dipanaskan akan memuai. Hipotesis: apakah emas, tembaga, timah, perak, platinum (merupakan jenis logam) ketika dipanaskan akan memuai. Observasi: menguji apakah emas, tembaga, timah, perak, platinum ketika dipanaskan akan memuai atau tidak. Konfirmasi: 
ternyata teori yang ada terbukti setelah diadakan penelitian dengan pendekatan deduktif ini. Berikut ini merupakan gambar pola pikir deduktif.

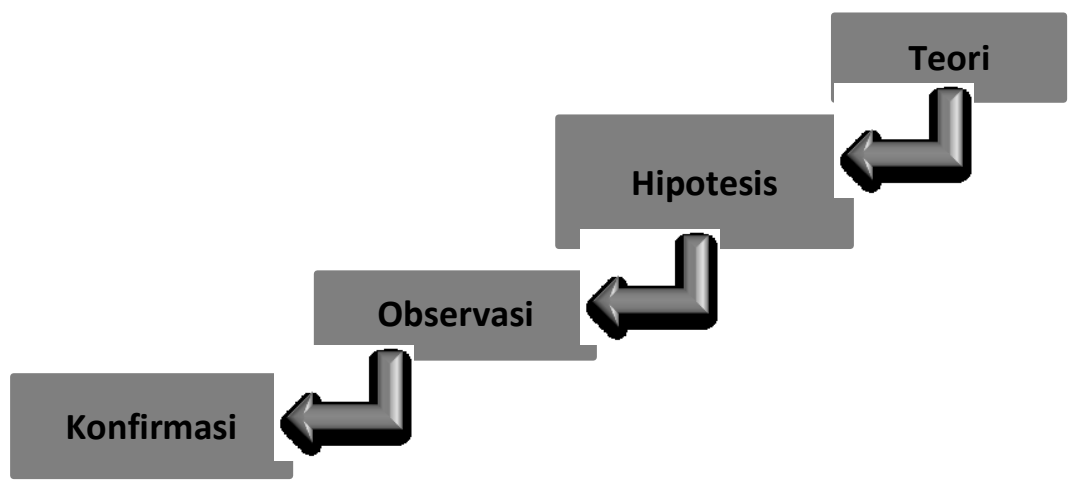

Gambar 2.1. Alur Berpikir Deduktif (Sujarweni, 2014)

Penelitian kuantitatif adalah suatu proses menemukan pengetahuan yang menggunakan data berupa angka sebagai alat menganalisis keterangan mengenai apa yang ingin kita ketahui. Analisis data dilakukan menggunakan teknik statistik untuk mereduksi dan mengelompokan data, menentukan hubungan serta mengidentifikasikan perbedaan antar kelompok data. Kontrol, instrumen, dan analisis statistik digunakan untuk menghasilkan temuantemuan penelitian secara akurat. Dengan demikian kesimpulan hasil uji hipotesis yang diperoleh melalui penelitian kuantitatif dapat diberlakukan secara umum.

Terdapat sejumlah situasi yang menunjukkan kapan sebaiknya penelitian kuantitatif dipilih (Sugiyono, 2017) sebagai pendekatan antara lain:

a) Bila masalah yang merupakan titik tolak penelitian sudah jelas Masalah adalah penyimpangan yang terjadi antara harapan dengan kenyataan, aturan dengan pelaksanaan, antara teori dengan praktek, antara rencana dengan impelementasi atau tantangan dengan kemampuan. Masalah ini harus ditunjukkan dengan data, baik hasil pangamatan sendiri maupun pencermatan dokumen. Misalnya penelitian kuantitatif untuk menguji efektivitas pembelajaran dalam meningkatkan prestasi belajar siswa, maka data prestasi belajar siswa sebagai masalah harus ditunjukkan.

b) Bila peneliti ingin mendapatkan informasi yang luas dari suatu populasi

Penelitian kuantitatif cocok digunakan untuk mendapatkan infomasi yang luas tetapi tidak mendalam. Bila populasi terlalu luas, maka penelitian dapat menggunakan sampel yang diambil dari populasi 
tersebut. Misalnya penelitian tentang disiplin kerja guru di Kabupaten Bandung. Peneliti dapat mengambil sampel yang representatif, tidak berarti harus semua guru di kabupaten Bandung menjadi sumber data penelitian.

c) Bila ingin diketahui sejauh mana pengaruh perlakuan/treatment terhadap subyek tertentu

Untuk kepentingan ini metode eksperimen paling cocok digunakan. Misalnya penelitian untuk mengetahui pengaruh penggunaan media pembelajaran audio-visual terhadap prestasi belajar siswa.

d) Bila peneliti bermaksud menguji hipotesis penelitian

Hipotesis penelitian dapat berbentuk dugaan mengenai hubungan antar variabel (hipotesis asosiatif) ataupun perbedaan skor variabel antar kelompok (hipotesis komparatif). Misalnya peneliti ingin mengetahui hubungan antara motivasi kerja dengan kinerja guru. Hipotesis asosiatif yang diuji dalam penelitian ini adalah: "Terdapat hubungan antara motivasi kerja dengan kinerja guru".

e) Bila peneliti ingin mendapatkan data yang akurat, berdasarkan fenomena yang empiris dan dapat diukur

Misalnya ingin mengetahui IQ guru pada sekolah tertentu, maka dilakukan pengukuran melalui tes IQ terhadap guru-guru pada sekolah yang bersangkutan.

f) Bila peneliti ingin menguji terhadap adanya suatu keraguan tentang kebenaran pengetahuan, teori, dan produk atau kegiatan tertentu Misalnya peneliti ingin mengetahui variabel yang lebih efektif apakah pembelajaran menggunakan metode diskusi atau penugasan. Dalam hal ini, peneliti harus mengukur hasil belajar siswa yang menggunakan metode diskusi dan hasil belajar siswa yang menggunakan metode penugasan. Pada tahap selanjutnya hasil pengukuran tersebut dibandingkan.

\section{Penelitian kualitatif}

Penelitian kualitatif sifatnya deskriptif analitik. Data yang diperoleh seperti hasil pengamatan, hasil wawancara, hasil pemotretan, analisis dokumen, catatan lapangan, disusun peneliti di lokasi penelitian, tidak dituangkan dalam bentuk angka-angka. Hasil analisis data berupa pemaparan mengenai situasi yang diteliti yang disajikan dalam bentuk uraian naratif. Hakikat pemaparan data pada umumnya menjawab pertanyaan-pertanyaan mengapa dan bagaimana suatu fenomena terjadi. Untuk itu peneliti dituntut memahami dan menguasai bidang ilmu yang ditelitinya sehingga dapat memberikan justifikasi 
mengenai konsep dan makna yang terkandung dalam data. Misalnya ketika peneliti ingin mengetahui peran kepala sekolah dalam pembinaan guru, berdasarkan data/informasi yang ada peneliti harus mampu menguraikan tujuan kepala sekolah dalam pembinaan guru, langkah-langkah yang dilakukan kepala sekolah dalam pembinaan guru, serta bagaimana respon guru terhadap pembinaan yang dilakukan oleh kepala sekolah.

Penelitian kualitatif sifatnya induktif. Argumen induktif yang baik merupakan argumen yang benar dengan premis yang bisa memberikan alasan yang jelas dan benar tentang kebenaran dari kesimpulan. Contoh Observasi: emas ketika dipanaskan memuai, tembaga ketika dipanaskan memuai, timah ketika dipanaskan memuai. Pola dan Hipotesis: ketiganya merupakan logam dan ketiganya ketika akan dipanaskan memuai. Teori baru: logam ketika dipanaskan akan memuai. Berikut ini merupakan gambar pola berpikir induktif.

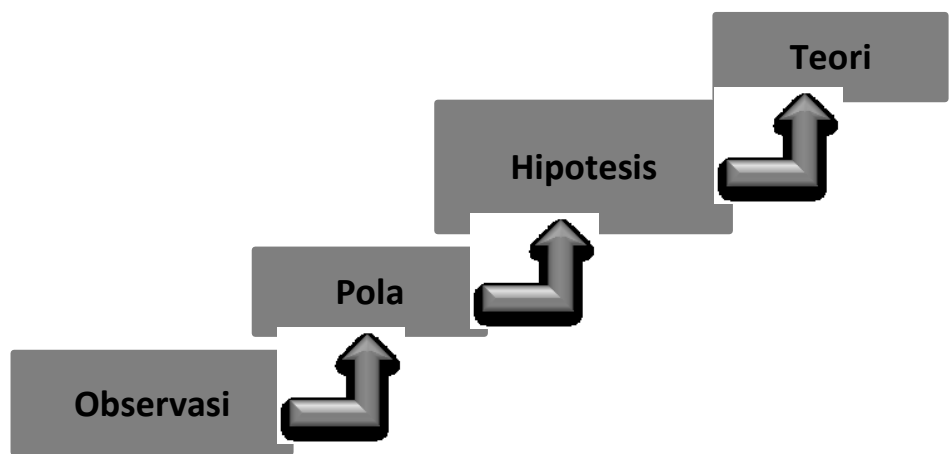

Gambar 2.2. Alur Berpikir Induktif (Sujarweni, 2014)

Penelitian kualitatif tidak dimulai dari deduksi teori, tetapi dimulai dari lapangan yakni fakta empiris. Peneliti terjun ke lapangan, mempelajari suatu proses atau penemuan yang tenjadi secara alami, mencatat, menganalisis, menafsirkan dan melaporkan serta menarik kesimpulan-kesimpulan dari proses tersebut. Kesimpulan atau generalisasi kepada lebih luas tidak dilakukan, sebab proses yang sama dalam konteks lingkungan tertentu, tidak mungkin sama dalam konteks lingkungan yang lain baik waktu maupun tempat. Temuan penelitian dalam bentuk konsep, prinsip, hukum, teori dibangun dan dikembangkan dari lapangan bukan dari teori yang telah ada. Prosesnya induktif yaitu dari data yang terpisah namun saling berkaitan. Misalnya ketika meneliti peran kepala sekolah dalam membina guru, peneliti harus berusaha menemukan prinsip dan konsep-konsep atas dasar fakta. Peneliti tidak berupaya menerapkan teori/konsep yang terkait dengan 
pembinaan, akan tetapi berusaha menemukan konsep berdasarkan fakta dari lapangan.

Terdapat sejumlah situasi yang menunjukkan kapan sebaiknya penelitian kualitatif (Sugiyono, 2017) dipilih sebagai pendekatan antara lain:

a) Bila masalah penelitian belum jelas. Kondisi semacam ini cocok diteliti dengan pendekatan kualitatif, karena peneliti kualitatif akan langsung masuk pada situasi, melakukan eksplorasi, sehingga masalah ditemukan dengan jelas.

b) Bila peneliti ingin memahami makna dibalik data yang tampak. Gejala sosial sering tidak dapat dipahami berdasarkan apa yang diucapkan dan dilakukan orang. Misalnya persepsi guru tentang kepemimpinan kepala sekolah akan berbeda dengan persepsi kepala sekolah. Data untuk mencari makna kepemimpinan kepala sekolah tersebut hanya cocok diteliti dengan metode kualitatif misalnya melalui wawancara mendalam, observasi, dan juga pencermatan dokumen.

c) Bila peneliti ingin memahami interaksi sosial. Interaksi sosial yang kompleks hanya dapat diurai kalau peneliti melakukan penelitian kualitatif dengan cara berperan serta, wawancara mendalam terhadap interaksi sosial tersebut. Misalnya pemahaman terhadap kepemimpinan kepala sekolah hanya dapat dilakukan melalui kajian mendalam bukan hanya pengukuran sepintas. Dengan demikian dapat ditemukan pola hubungan yang jelas sehingga dapat ditemukan hipotesis yang berupa hubungan antar gejala. Bila hipotesis terbukti, maka akan menjadi tesis atau menjadi teori.

d) Bila peneliti ingin memastikan kebenaran data. Data sosial sering sulit dipastikan kebenarannya. Melalui berbagai teknik pengumpulan data kualitatif, kepastian data akan lebih terjamin. Melalui pendekatan kualitatif data yang diperoleh diuji kredibilitasnya, penelitian berakhir setelah data itu jenuh sehingga kepastian data dapat diperoleh. Misalnya untuk mencari gaya kepemimpinan seperti apa yang sebaiknya diterapkan kepala sekolah dalam membina guru, sebelum ditemukan gaya yang tepat maka penelitian belum dinyatakan selesai.

e) Memahami perasaan orang. Perasaan orang sulit dimengerti kalau tidak diteliti dengan pendekatan penelitian kualitatif, dengan teknik pengumpulan data wawancara mendalam, dan observasi berperan 
serta untuk ikut serta merasakan apa yang dirasakan orang tersebut.

f) Bila ingin meneliti tentang sejarah atau perkembangan. Sejarah atau perkembangan kehidupan seseorang atau kelompok orang dapat dilacak melalui pendekatan kualitatif. Misalnya sejarah perkembangan sekolah sehingga sekolah tersebut menjadi sekolah favorit dalam padangan masyarakat dan orang tua siswa.

g) Untuk mengembangkan teori. Metode kualitatif paling cocok digunakan untuk mengembangkan teori yang dibangun melalui data yang diperoleh melalui lapangan. Teori yang demikian dibangun melalui grounded reseacrh. Dengan metode kualitatif peneliti pada tahap awalnya melakukan penjelajahan, selanjutnya melakukan pengumpulan data yang mendalam sehingga dapat ditemukan hipotesis yang berupa hubungan antar gejala. Hipotesis tersebut selanjutnya diverifikasi dengan pengumpulan data yang lebih mendalam. Bila hipotesis tersebut terbukti, maka akan menjadi tesis atau teori.

\section{B. PERBEDAAN PENELITIAN KUANTITATIF DAN KUALITATIF}

Antara penelitian kuantitatif dan kualitatif terdapat perbedaan yang sifatnya mendasar, meskipun beberapa hal juga memiliki persamaan. Tabel berikut disajikan perbedaan dari kedua pendekatan tersebut.

Tabel 2.1. Perbedaan penelitian Kuantitatif dan Kualitatif

\begin{tabular}{|c|c|c|}
\hline No & Penelitian Kuantitatif & Penelitian Kualitatif \\
\hline 1. & $\begin{array}{l}\text { A. Desain } \\
\text { a) Spesifik, jelas, rinci } \\
\text { b) Ditentukan secara mantap } \\
\text { sejak awal } \\
\text { c) Menjadi pegangan } \\
\text { langkah demi langkah }\end{array}$ & $\begin{array}{l}\text { A. Desain } \\
\text { a) umum } \\
\text { b) Fleksibel } \\
\text { c) Berkembang, dan muncul } \\
\text { dalam proses penelitian }\end{array}$ \\
\hline 2. & $\begin{array}{l}\text { B. Tujuan } \\
\text { a) Menunjukan hubungan } \\
\text { antar variabel } \\
\text { b) Menguji teori } \\
\text { c) Mencari generalisasi yang } \\
\text { mempunyai nilai prediktif }\end{array}$ & $\begin{array}{l}\text { B. Tujuan } \\
\text { a) Menemukan pola yang } \\
\text { bersifat interaktif } \\
\text { b) Menemukan teori } \\
\text { c) Menggambarkan realitas } \\
\text { yang kompleks } \\
\text { d) Memperoleh pemahaman }\end{array}$ \\
\hline
\end{tabular}




\begin{tabular}{|c|c|c|}
\hline & & makna \\
\hline 3. & $\begin{array}{l}\text { C. Teknik Pengumpulan Data } \\
\text { a) Kuisioner } \\
\text { b) Observasi dan wawancara } \\
\text { terstruktur }\end{array}$ & $\begin{array}{l}\text { C. Teknik Pengumpulan Data } \\
\text { a) Participant observation } \\
\text { b) In deptd interview } \\
\text { c) Dokumentasi } \\
\text { d) Triangulasi }\end{array}$ \\
\hline 4. & $\begin{array}{l}\text { D. Instrumen Penelitian } \\
\text { a) Tes, angket, wawancara } \\
\text { terstruktur } \\
\text { b) Instrumen yang telah } \\
\text { terstandar }\end{array}$ & $\begin{array}{l}\text { D. Instrumen Penelitian } \\
\text { a) Peneliti sebagai instrumen } \\
\text { (human instrument) } \\
\text { b) Buku catatan, tape recorder, } \\
\text { camera, handycam, dll }\end{array}$ \\
\hline 5. & $\begin{array}{l}\text { E. Data } \\
\text { a) Kuantitatif } \\
\text { b) Hasil pengukuran } \\
\text { variabel yang } \\
\text { dioperasionalkan dengan } \\
\text { menggunakan instrumen }\end{array}$ & $\begin{array}{l}\text { E. Data } \\
\text { a) Deskripsi kualitatif } \\
\text { b) Dokumen pribadi, catatan } \\
\text { lapangan dan tindakan } \\
\text { responden, dokumen dll }\end{array}$ \\
\hline 6. & $\begin{array}{l}\text { F. Sampel } \\
\text { a) Besar } \\
\text { b) Representatif } \\
\text { c) Sedapat mungkin random } \\
\text { d) Ditentukan sejak awal }\end{array}$ & $\begin{array}{l}\text { F. Sampel } \\
\text { a) Kecil } \\
\text { b) Tidak representatif } \\
\text { c) Purposive, snowball } \\
\text { d) Berkembang selama proses } \\
\text { penelitian }\end{array}$ \\
\hline 7. & $\begin{array}{l}\text { G. Analisis } \\
\text { a) Setelah selesai } \\
\text { b) Pengumpulan data } \\
\text { c) Deduktif } \\
\text { d) Menggunakan statistik } \\
\text { untuk menguji hipotesis }\end{array}$ & $\begin{array}{l}\text { G. Analisis } \\
\text { a) Terus menerus sejak awal } \\
\text { sampai akhir penelitian } \\
\text { b) Induktif } \\
\text { c) Mencari pola, model, tema, } \\
\text { teori }\end{array}$ \\
\hline 8. & $\begin{array}{l}\text { H. Hubungan dengan } \\
\text { Responden } \\
\text { a) Dibuat berjarak, bahkan } \\
\text { sering tanpa kontak } \\
\text { supaya obyektif } \\
\text { b) Kedudukan peneliti lebih } \\
\text { tinggi dari responden } \\
\text { c) Jangka pendek sampai }\end{array}$ & $\begin{array}{l}\text { H. Hubungan dengan Responden } \\
\text { a) Empati, akrab supaya } \\
\text { memperoleh pemahaman } \\
\text { yang mendalam } \\
\text { b) Kedudukan sama bahkan } \\
\text { sebagai guru, konsultan } \\
\text { c) Jangka lama, sampai datanya } \\
\text { jenuh, dapat ditemukan }\end{array}$ \\
\hline
\end{tabular}




\begin{tabular}{|c|c|c|}
\hline & $\begin{array}{l}\text { hipotesis dapat } \\
\text { dibuktikan }\end{array}$ & hipotesis atau teori \\
\hline 9. & $\begin{array}{l}\text { I. Usulan Desain } \\
\text { a) Luas dan rinci } \\
\text { b) Literatur yang } \\
\text { berhubungan dengan } \\
\text { masalah, dan variabel } \\
\text { yang diteliti } \\
\text { c) Prosedur yang spesifik } \\
\text { dan rinci langkah- } \\
\text { langkahnya } \\
\text { d) Masalah dirumuskan } \\
\text { dengan spesifik dan jelas } \\
\text { e) Hipotesis dirumuskan } \\
\text { dengan jelas } \\
\text { f) Ditulis secara rinci dan } \\
\text { jelas sebelum terjun ke } \\
\text { lapangan }\end{array}$ & $\begin{array}{l}\text { I. Usulan Desain } \\
\text { a) Singkat, umum bersifat } \\
\text { sementara } \\
\text { b) Literatur yang digunakan } \\
\text { bersifat sementara, tidak } \\
\text { menjadi pegangan utama } \\
\text { c) Prosedur bersifat umum, } \\
\text { seperti akan merencanakan } \\
\text { tour atau piknik } \\
\text { d) Masalah bersifat sementara } \\
\text { dan akan ditemukan setelah } \\
\text { studi pendahuluan } \\
\text { e) Tidak dirumuskan hipotesis, } \\
\text { karena justru akan } \\
\text { menemukan hipotesis } \\
\text { f) Fokus penelitian ditetapkan } \\
\text { setelah diperoleh data awal } \\
\text { dari lapangan }\end{array}$ \\
\hline 10. & $\begin{array}{l}\text { J. Kapan penelitian dianggap } \\
\text { selesai? } \\
\text { Setelah semua kegiatan yang } \\
\text { direncanakan dapat } \\
\text { diselesaikan }\end{array}$ & $\begin{array}{l}\text { J. Kapan penelitian dianggap } \\
\text { selesai? } \\
\text { Setelah tidak ada data yang } \\
\text { dianggap baru/jenuh }\end{array}$ \\
\hline 11. & $\begin{array}{l}\text { K. Kepercayaan terhadap hasil } \\
\text { penelitian } \\
\text { Pengujian validitas dan } \\
\text { reliabilitas instrumen }\end{array}$ & $\begin{array}{l}\text { K. Kepercayaan terhadap hasil } \\
\text { penelitian } \\
\text { Pengujian kredibilitas, } \\
\text { depenabilitas, proses dan hasil } \\
\text { penelitian }\end{array}$ \\
\hline
\end{tabular}

(Sugiyono, 2017)

\section{JENIS PENELITIAN BERDASARKAN SIFAT PERMASALAHAN}

Jenis penelitian dilihat dari segi permasalahannya dibedakan menjadi: penelitian eksperimen, deskriptif, pengembangan (Research and Development) dan desain riset (Design Research). Penelitian deskriptif berusaha memberikan dengan sistematis dan cermat fakta-fakta aktual dan 
sifat populasi. Penelitian eksperimen memanipulasi atau merekayasa, mengatur, mengontrol atau mengendalikan situasi alamiah menjadi situasi artifisial/ buatan. Dalam penelitian ini dilakukan percobaan terhadap kelompok-kelompok eksperimen. Kepada tiap kelompok eksperimen dikenakan perlakuan-perlakuan tertentu dengan kondisi-kondisi yang dapat dikontrol. Penelitian deskriptif menghasilkan keterangan yang menggambarkan ciri-ciri gejala saja, tidak berusaha menjelaskan sebab-akibat.

Metode Penelitian dan Pengembangan atau Research and Development (R\&D) adalah metode penelitian yang digunakan untuk menghasilkan produk tertentu, dan menguji keefektifan produk tersebut. Dalam penelitian ini perlu memadukan beberapa jenis metode penelitian, antara lain jenis peneltian survei dengan eksperimen atau action research dan evaluasi. Produk tidak selalu berbentuk benda atau perangkat keras (hardware), seperti buku, modul, alat bantu pembelajaran di kelas atau di laboratorium, tetapi bisa juga perangkat lunak (software), seperti program komputer untuk pengolahan data, pembelajaran di kelas, perpustakaan atau laboratorium, ataupun modelmodel pendidikan, pembelajaran, pelatihan, bimbingan, evaluasi, manajemen.

Perancangan pembelajaran atau dikenal dengan istilah desain pembelajaran adalah seperangkat kegiatan merancang kegiatan pembelajaran beserta hal-hal yang diperlukan dalam pembelajaran tersebut untuk mencapai tujuan pembelajaran yang dicanangkan. Kegiatan ini meliputi: kegiatan perumusan tujuan pembelajaran (ending point), pengkajian keadaan siswa sasaran (starting point), perumusan hipotesis lintasan belajar (hypothetical learning trajectory) untuk mencapai tujuan pembelajaran dengan memperhatikan keadaan siswa sasaran, dan penentuan durasi waktu pelaksanaan kegiatan pembelajaran, serta perumusan mekanisme evaluasi untuk mengkaji keberhasilan rancangan pembelajaran dalam mencapai tujuan pembelajaran. Dalam merancang pembelajaran desain pembelajaran yang baik idealnya dirumuskan dan disusun berdasarkan dan atau memperhatikan teori-teori atau kajian-kajian pembelajaran yang relevan dan sudah diakui keabsahannya.

\section{KASUS}

Guru SD Inpres Allang sangat prihatin dengan apa yang dihadapi di sekolah tempat dia mengajar. Beberapa keprihatihan yang berkaitan dengan kondisi siswa antara lain: (a) rendahnya penguasaan simbol pada mata pelajaran matematika (b) rendahnya kemampuan matematis, dan (3) rendahnya kemampuan berpikir kritis dalam menyelesaikan soal. Jika kita kaitkan dengan ragam penelitian pendidikan yang telah dipelajari, hal berikut coba dilakukan. 
1. Jika ingin melakukan penelitian kuantitatif, pilih salah satu keprihatinan yang dihadapi guru SD tersebut, kemudian jelaskan langkah-langkah apa yang akan dilakukan!

2. Jika ingin melakukan penelitian kualitatif, pilih salah satu keprihatinan yang dihadapi guru SD tersebut, kemudian jelaskan langkah-langkah apa yang akan dilakukan!

3. Jika ingin meneliti tentang profesionalisme guru SD tersebut, desain penelitian apa yang akan dipilih. Jelaskan dan berikan alasan.

\section{RANGKUMAN}

Jenis penelitian berdasarkan pendekatan yang digunakan terbagi atas jenis penelitian kuantitatif dan kualitatif. Jenis penelitian kualitatif menggunakan pola pikir induktif yang berusaha memahami suatu fenomena dengan cara menggunakan konsep-konsep bersifat umum, yang abstrak untuk mencari halhal yang bersifat khusus dari fenomena yang diteliti. Sedangkan pada jenis penelitian kualitatif sifatnya induktif yang dimulai dari lapangan yakni fakta empiris. Peneliti terjun ke lapangan, mempelajari suatu proses atau penemuan yang tenjadi secara alami, mencatat, menganalisis, menafsirkan dan melaporkan serta menarik kesimpulan-kesimpulan dari proses tersebut.

Jenis dilihat dari segi permasalahannya dibedakan menjadi: penelitian eksperimen, deskriptif, pengembangan (Research and Development) dan desain riset (Design Research). Penelitian deskriptif berusaha memberikan dengan sistematis dan cermat fakta-fakta aktual dan sifat populasi. Penelitian eksperimen memanipulasi atau merekayasa, mengatur, mengontrol atau mengendalikan situasi alamiah menjadi situasi artifisial/ buatan. Penelitian dan Pengembangan atau Research and Development (R\&D) adalah metode penelitian yang digunakan untuk menghasilkan produk tertentu, dan menguji keefektifan produk tersebut. Dalam penelitian ini perlu memadukan beberapa jenis metode penelitian, antara lain jenis peneltian survei dengan eksperimen atau action research dan evaluasi. Produk tidak selalu berbentuk benda atau perangkat keras (hardware), tetapi bisa juga perangkat lunak (software). Penelitian desain (design research) merupakan praktik pembelajaran (teaching experiment) dengan memperhatikan desain pembelajaran yang telah dibuat berdasarkan teori atau kajian pembelajaran yang relevan dan sudah diakui keabsahannya.

Dengan demikan jenis penelitian berdasarkan pendekatan memiliki persamaan dan perbedaan. Atau jenis penelitian dari segi masalah mempunyai prosedur penelitian masing-masing. 


\section{TUGAS}

Cari masing-masing jurnal penelitian pembelajaran matematika terbitan 4 tahun terakhir dengan menggunakan jenis-jenis penelitian seperti: penelitian deskriptif, eksperimen, pengembangan (Research and Development), desain riset (Design Research). Kemudian cermati informasi apa saja yang dikomunikasikan oleh peneliti untuk setiap bagian artikel. 


\section{BAB 3 \\ MASALAH PENELITIAN}

$\mathrm{S}$ etiap penelitian baik penelitian kuantitatif maupun kualitatif selalu berangkat dari masalah. Masalah merupakan suatu pernyataan yang memerlukan pembahasan, pemecahan, informasi yang menyiratkan adanya kemungkinan pengumpulan dan analisis data secara empiris. Pada umumnya peneliti dalam bidang pendidikan memfokuskan kajiannya pada usaha untuk mendeskripsikan fenomena kependidikan, menjelaskan kejadian yang terobservasi, dan mengembangkan suatu pemecahan masalah kependidikan. Disamping itu, peneliti juga bisa mengajukan berbagai pertanyaan baik yang bersifat praktis maupun teoritis di bidang pendidikan. Akan tetapi, tidak semua pertanyaan dapat digolongkan ke dalam masalah penelitian. Pada bab ini akan dibicarakan bagaimana mengidentifikasi, memilih masalah, dan merumuskan masalah baik itu dengan menggunakan penelitian kuantitatif atau kualitatif. Kemampuan akhir yang diharapkan setelah mahasiswa mempelajari bab ini yaitu:

1. Memilih sumber-sumber relevan yang dapat dijadikan acuan untuk mengidentifikasi masalah penelitian

2. Mengkategorikan karakteristik masalah pendidikan

3. Memilih dan merumuskan masalah

4. Merumuskan tujuan penelitian

\section{A. SUMBER MASALAH}

Setiap penelitian baik menggunakan jenis penelitian kuantitatif maupun kualitatif selalu berangkat dari masalah. Namun terdapat perbedaan yang mendasar antara "masalah" dalam penelitian kuantitatif dan "masalah" dalam penelitian kualitatif. Pada penelitian kuantitatif, masalah yang dipecahkan melalui penelitian harus jelas, spesifik, dan dianggap tidak berubah, tetapi dalam penelitian kualitatif, masalah yang dibawa oleh peneliti masih remangremang, bahkan gelap, kompleks, dan dinamis. Oleh karena itu, masalah dalam penelitian kualitatif masih bersifat sementara, tentatif, dan akan berkembang atau diganti setelah peneliti berada dilapangan. Berikut ini akan dijelaskan berbagai sumber masalah pada penelitian kuantitatif dan kualitatif.

Pada dasarnya penelitian dilakukan dengan tujuan untuk mendapatkan data yang antara lain dapat digunakan untuk memecahkan masalah. Memilih masalah penelitian adalah suatu langkah awal suatu kegiatan penelitian. Bagi orang yang belum berpengalaman meneliti, menentukan atau memilih masalah bukanlah pekerjaan yang mudah, bahkan dikatakan sulit. Dari mana masalah 
diperoleh? Yang jelas, masalah mesti merupakan bagian dari kebutuhan sesorang untuk dipecahkan. Masalah adalah kesenjangan antara harapan akan sesuatu yang seharusnya ada (das Sollen) dengan kenyataan yang ada (das sein), antara kebutuhan dengan yang tersedia, antara yang seharusnya (what should be) dengan yang ada (what it is). Masalah-masalah dapat diketahui atau dicari apabila terdapat penyimpangan antara pengalaman dengan kenyataan, antara apa yang direncanakan dengan kenyataan, adanya pengaduan, dan kompetisi (Stonner, 1982).

Masalah yang dapat diselidiki sebenarnya tak terbatas jumlahnya, namun seringkali calon peneliti mengalami kesulitan untuk menemukan masalah yang cocok baginya. Masalah penelitian dapat dipandang sebagai variabel yang menjadi tema pokok penelitian, sehingga ia pada mulanya dapat diidentifikasi melalui topik yang umum. Identifikasi masalah adalah mengklasifikasikan informasi yang mengakibatkan munculnya kesenjangan dalam pengetahuan kita, bila ada hasil-hasil yang bertentangan, bila ada suatu kenyataan dan kita bermaksud menjelaskan melalui penelitian. Sumber-sumber yang dapat dijadikan acuan untuk mengidentifikasi masalah penelitian diantaranya:

\section{1) Penyimpangan antara pengalaman dengan kenyataan}

Di dunia ini yang tetap hanya perubahan, namun sering perubahan itu tidak diharapkan oleh orang-orang tertentu, karena akan dapat menimbulkan masalah. Orang yang biasanya menjadi pimpinan pada bidang pemerintah harus berubah ke bidang pendidikan. Hal ini pada awalnya tentu akan muncul masalah. Orang atau kelompok yang biasanya mengelola pendidikan dengan sistem sentralisasi lalu berubah menjadi desentralisasi, atau dengan Manajemen Berbasis Sekolah (MBS) maka akan muncul masalah. Orang biasanya menulis menggunakan mesin ketik manual harus diganti dengan komputer, maka akan muncul masalah. Apakah masalah sehingga perlu ada perubahan. Apakah masalahnya dengan sistem sentralisasi, sehingga perlu berubah menjadi sistem desentralisasi dalam penyelenggaraan pemerintahan, apakah masalahnya sehingga kebijakan pendidikan selalu berubah, ganti menteri ganti kebijakan? Apakah masalahnya setelah terjadi perubahan?

\section{2) Observasi terhadap praktik pendidikan}

Observasi terhadap praktik pendidikan merupakan sumber yang kaya akan masalah penelitian. Masalah penelitian dapat diangkat dari hasil observasi terhadap hubungan tertentu yang belum atau tidak mempunyai dasar penjelasan yang memadai, dan cara-cara 
rutin dalam melakukan suatu tindakan yang didasarkan atas otoritas atau tradisi. Misalnya, seorang ahli dari staf BP3K melihat dalam peninjauan daerah terdapat banyak anak-anak dari usia sekolah tidak bersekolah walaupun SD Inpres sudah ada di tempat itu.

\section{3) Deduksi dari teori}

Teori merupakan konsep yang masih berisi tentang prinsip-prinsip umum yang penerapannya belum diketahui selama belum diuji secara empiris. Penelitian terhadap masalah yang diangkat dari teori pendidikan sangat berguna untuk mendapatkan penjelasan empiris praktis tentang teori tersebut.

\section{4) Kepustakaan tentang hasil penelitian}

Jurnal-jurnal penelitian merupakan laporan hasil-hasil penelitian yang dapat dijadikan sumber masalah. Laporan penelitian yang baik biasanya mencantumkan rekomendasi untuk penelitian lebih lanjut, yang berkaitan dengan penelitian tersebut.

Misalnya hasil penelitian dari (Farman \& Yusryanto, 2018) tentang PENGEMBANGAN DESAIN PEMBELAJARAN BERBASIS PROBLEM POSING DALAM UPAYA MENINGKATKAN KEMAMPUAN PENALARAN KONSEP LINGKARAN PADA SISWA SMP KELAS VIII.

Menyimpulkan bahwa hasil pengembangan desain pembelajaran materi lingkaran dengan model Isman yang menggunakan pendekatan problem posing berseting kooperatif memenuhi kriteria yang ditetapkan yaitu valid, praktis, dan efektif. Berdasarkan analisis data, pembahasan, dan kesimpulan maka saran yang diberikan adalah Pembelajaran ini dapat dikembangkan untuk materi yang lain, disesuaikan dengan indikator pencapaian dalam mendukung pengembangan kemampuan penalaran siswa atau kemampuan-kemampuan yang lain, seperti kemampuan komunikasi dan sebagainya.

\section{5) Masalah sosial}

Masalah sosial yang sedang terjadi dapat memberikan masukan yang berarti bagi peneliti lain untuk dijadikan masalah penelitian. Misalnya masalah perkelahian antar pelajar, banyaknya pengangguran dikalangan lulusan perguruan tinggi, menurunnya NEM (nilai ebtanas murni), dan lain sebagainya. 


\section{6) Situasi praktis}

Situasi praktis terutama dalam kaitannya dalam pembuatan keputusan tertentu, seringkali mendesak diadakannya penelitian evaluatif. Misalnya, seorang administrator pendidikan di kabupaten Maluku Tengah mengatakan bahwa kemunduran mutu pendidikan di Maluku Tengah disebabkan mundurnya dedikasi guru-guru di SD sampai SMA. Seorang peneliti tergugah untuk menguji kebenaran pernyataan itu.

\section{7) Pengalaman pribadi}

Pengalaman pribadi dapat memunculkan masalah yang memerlukan jawaban empiris untuk mendapatkan pemahaman yang mendalam. Orang yang terlibat secara langsung dalam situasi tertentu akan lebih peka dalam memahami makna yang berkaitan dengan situasi tersebut. Umpamanya, seorang dosen setelah mengajar selama beberapa tahun memperhatikan bahwa mahasiswa dari sekolah-sekolah kejuruan yang telah bekerja sedikitnya dua tahun semua berhasil mengikuti kuliahnya dengan baik.

Contohnya penelitian yang dilakukan oleh (Purnomo et al., 2018) tentang PENGEMBANGAN MEDIA PEMBELAJARAN BERBASIS ANDROID PADA MATA KULIAH STATISTIKA PENDIDIKAN.

Berdasarkan tahapan pengembangan media pembelajaran dapat disimpulkan bahwa dihasilkan media pembelajaran berbasis android pada mata kuliah Statistika Pendidikan yang valid. Hasil validasi ahli dengan rata-rata 4.22 dengan kategori sangat baik. Respon mahasiswa terhadap media pembelajaran sangat baik dengan nilai rata-rata sebesar 3.40.

\section{8) Adanya kompetisi}

Adanya saingan atau kompetisi sering dapat menimbulkan masalah besar, tidak dapat dimanfaatkan untuk kerja sama. Misalnya perusahan Pos dan Giro merasa mempunyai masalah setelah ada biro jasa lain yang menerima titipan surat, titipan barang, ada hand phone yang dapat digunakan untuk SMS, Whatsapp, internet, email. Perusahaan Kereta Api memandang angkutan umum jalan raya dengan Bus sebagai pesaing, sehingga menimbulkan masalah. Tetapi mungkin PT. Telkom kurang mempunyai masalah karena tidak ada perusahaan lain yang memberikan jasa yang sama lewat telepon 
kabel, tetapi menjadi masalah setelah ada saingan telepon genggam (hand phone). Berikan contoh dalam bidang pendidikan.

9) Pertemuan ilmiah

Masalah dapat diperoleh melalui pertemuan-pertemuan ilmiah, seperti seminar, diskusi, lokakarya, konferensi, dan sebagainya. Peserta-peserta seminar, diskusi dan pertemuan ilmiah membawa makalah-makalah yang memecahkan permasalahan menurut bidangnya masing-masing. Mungkin saja masalah itu perlu diteliti pula dari segi ilmu yang lain.

Sumber-sumber di atas dapat saling mempengaruhi dalam melahirkan suatu masalah penelitian, dapat juga berdiri sendiri. Jadi, sumber-sumber masalah tersebut dapat saling berinteraksi dalam melahirkan masalah penelitian, dapat juga melalui salah satu sumber saja. Setelah masalah diidentifikasi, selanjutnya perlu dipilih dan ditentukan masalah yang akan diangkat dalam suatu penelitian. Untuk memilih dan menentukan masalah yang layak untuk diteliti, perlu mempertimbangkan kriteria problematika yang baik.

Pada penelitian kualitatif, akan terjadi tiga kemungkinan terhadap masalah yang dibawa oleh peneliti dalam penelitian yaitu sebagai berikut:

1) Masalah yang dibawa oleh peneliti tetap, sehingga sejak awal sampai akhir penelitian sama

Dapat dikatakan judul proposal dengan judul penelitian sama.

2) Masalah yang dibawa oleh peneliti setelah memasuki penelitian berkembang yaitu memperluas atau memperdalam masalah yang telah disiapkan

Dapat disimpulkan tidak banyak perubahan, sehingga judul penelitian cukup disempurnakan.

3) Masalah yang dibawa peneliti setelah memasuki lapangan berubah total, sehingga harus mengganti masalah penelitian

Dengan demikian judul proposal dengan judul penelitian tidak sama dan judulnya diganti. Dalam institusi tertentu, judul yang diganti ini sering mengalami kesulitan kualitatif, harus mau mampu menyesuaikan dengan karakteristik masalah kualitatif ini.

\section{B. KRITERIA PEMILIHAN MASALAH}

Masalah dapat dipilih berdasarkan pertimbangan pribadi dan praktis. Namun, ada pula kriteria yang bersifat ilmiah yang perlu diperhatikan agar masalah penelitian itu memberikan sumbangan kepada perkembangan 
pengetahuan. Permasalahan yang akan diteliti menurut Kerlinger (Sukardi, 2003), hendaknya dapat memenuhi tiga kriteria penting yaitu:

1. Permasalahan atau problematika sebaiknya merefleksikan dua variabel atau lebih

2. Sebaiknya dinyatakan dalam bentuk pertanyaan yang jelas dan tidak meragukan

3. Sebaiknya dapat diuji secara empiris

Tiga kriteria ini penting sebagai petimbangan peneliti dalam mengidentifikasi permasalahan yang ditemui, baik dalam teori maupun di lapangan. Para peneliti sebaiknya dapat memilih dari problematika yang ditemu menjadi dua klasifikasi, yaitu problematika yang bersifat belum dapat diukur karena baru atas dasar pertimbangan common sense, dan permasalahan yang betul-betul permasalahan yang layak diteliti dengan ciriciri: dapat diukur dengan instrumen penelitian, sering ditemui di lapangan, dan bermanfaat bagi ilmu pengetahuan.

Dalam memilih masalah pada penelitian kuantitatif atau penelitian kualitatif yang diperoleh dari sumber-sumber di atas, peneliti hendaknya mempertimbangkan beberapa faktor berikut, yaitu:

\section{Baru, untuk menghindari adanya duplikasi}

Seorang peneliti sebaiknya menghindari mengangkat masalah yang sudah ada informasi yang jelas dari penelitian lain. Untuk itu peneliti harus mencari informasi tentang penelitian yang sudah pernah dilakukan oleh peneliti lain dari berbagai sumber, sehingga yakin bahwa masalah yang diangkat untuk diteliti bukan sekedar pengulangan masalah yang sudah pernah diteliti. Replikasi dari penelitian orang lain dapat diterima untuk dilakukan hanya bila masalah penelitian tersebut belum menyajikan informasi yang teruji dengan validitas internal (validitas yang diperoleh dengan mengkorelasikan pendapat para pakar dan diambil kesimpulan oleh peneliti) dan validitas eksternal (validitas yang diperoleh dengan mengkorelasikan alat pengukur baru dengan alat ukur yang valid) secara meyakinkan karena keterbatasan sampel ataupun keterbatasan teoritis.

\section{Nilai manfaatnya bagi bidang kajian pendidikan}

Suatu penelitian harus dapat memberikan sumbangan yang berarti terhadap pengembangan pengetahuan di bidang kependidikan; diperlukan untuk menguji teori; dapat menghasikan kesimpulan 
yang dapat digeneralisasikan pada populasi atau praktik lain; dapat memperluas pemahaman terhadap kenyataan pendidikan tertentu; dapat mengembangkan metodologi; dapat mengevaluasi praktik tertentu untuk suasana tertentu.

\section{Menarik dan menantang secara intelektual}

Permasalahan yang diangkat harus didasarkan pada minat serta rasa ingin tahu yang mendalam, sehingga peneliti melakukan penelitiannya dengan senang hati dan sungguh-sungguh.

\section{Latihan serta kualifikasi personal}

Pemilihan masalah yang tidak sesuai dengan bidang yang dikuasai dapat menimbulkan permasalahan dalam proses penelitiannya dan sulit diharapkan untuk menghasilkan karya penelitian yang berarti.

\section{Tersedianya data dan metode}

Data yang dipertimbangkan harus memenuhi syarat-syarat ketelitian, obyektif, dan dapat diuji. Disamping itu, peneliti harus memgenal dengan baik beberapa prosedur penelitian yang dapat digunakan serta instrumen atau alat pengumpul data bagi penelitiannya.

\section{Alat khusus dan kondisi kerja}

Agar proses penelitian dapat berjalan dengan baik, peneliti harus mempertimbangkan ketersediaan peralatan dan kondisi yang diperlukan. Misalnya bila tidak ada komputer untuk mengolah data statistik yang memerlukan teknis analisis yang kompleks, peneliti hendaknya meninjau kembali masalah yang memerlukan analisis yang rumit.

7. Tersedianya sponsor dan kerjasama administratif

Penelitian kependidikan seringkali harus melibatkan beberapa pihak yang berkepentingan, misalnya sekolah, depdikbud, konsultan atau pembimbing. Izin resmi dari pejabat yang berwenang diperlukan untuk dilaksanakannya penelitian. Oleh karena itu, peneliti harus menghindari mengangkat masalah yang kemungkinan besar sulit untuk mendapatkan dukungan dari pihakpihak yang terkait, misalnya mengoreksi kebijaksanaan pemerintah.

\section{Biaya dan hasil}

Sumber biaya yang diperlukan untuk kebutuhan penelitian harus diperhatikan. Bila biaya terbatas, masalah yang diangkat sebaiknya tidak terlalu luas sehingga dapat mencukupi untuk penyelesaiannya. Selain itu, hasil yang akan diperoleh dari penelitian tersebut juga 
harus dipertimbangkan apakah sepadan dengan biaya yang dikeluarkan.

9. Bahaya

Bahaya yang mungkin timbul bisa dari perorangan, kelompok, maupun profesi, baik bahaya fisik maupun sosial. Oleh karena itu, bila masalah yang akan diajukan kemungkinan akan membahayakan, hendaknya peneliti meninjau kembali.

\section{Waktu}

Beberapa penelitian naturalistik, historis, eksperimen, dan longitudinal seringkali memerlukan waktu yang cukup panjang untuk menyelesaikannya. Oleh karena itu, dalam memilih permasalahan peneliti harus mempertimbangkan waktu yang tersedia.

\section{RUMUSAN MASALAH}

Rumusan masalah berbeda dengan masalah. Jika masalah merupakan kesenjangan antara yang diharapkan dengan apa yang terjadi, maka rumusan masalah merupakan suatu pertanyaan yang akan dicarikan jawabannya melalui pengumpulan data. Namun demikian terdapat kaitan erat antara masalah dan rumusan masalah, karena setiap rumusan masalah penelitian harus didasarkan pada masalah.

Seperti yang telah disebutkan di atas, dalam pemilihan masalah peneliti harus mempertimbangkan beberapa kriteria agar penelitiannya memberikan sumbangan yang berarti dan dapat dikelola dengan baik. Selanjutnya, masalah yang sudah pilih atau ditentukan tersebut perlu dirumuskan secara jelas dan konkret. Rumusan masalah merupakan bentuk pertanyaan yang dapat memandu peneliti untuk mengumpulkan data di lapangan. Berdasarkan level of explanation suatu gejala, maka secara umum terdapat tiga bentuk rumusan masalah (Sugiyono, 2017), yaitu rumusan masalah deskriptif, komparatif, dan asosiatif.

\section{Rumusan masalah deskriptif}

Rumusan masalah deskriptif adalah suatu rumusan masalah yang berkaitan dengan pertanyaan terhadap keberadaan variabel mandiri, baik hanya pada satu variabel atau lebih (variabel yang berdiri sendiri). Jadi dalam penelitian ini peneliti tidak membuat perbandingan variabel itu pada sampel yang lain, dan mencari hubungan variabel itu dengan variabel yang lain. Penelitian semacam ini untuk selanjutnya dinamakan penelitian deskriptif. 


\section{Contoh rumusan masalah deskriptif:}

1) Seberapa baik kinerja Departemen Pendidikan Nasional?

2) Bagaimanakah sikap masyarakat terhadap perguruan tinggi negeri Berbadan Hukum?

3) Seberapa tinggi efektivitas kebijakan Manajemen Berbasis sekolah di Indonesia?

4) Seberapa tinggi tingkat kepuasan masyarakat terhadap pelayanan pemerintah daerah di bidang pendidikan?

5) Seberapa tinggi tingkat produktivitas dan keuntungan finansial Unit Produksi pada sekolah-sekolah Kejuruan?

6) Seberapa tinggi minat baca dan lama belajar rata-rata per hari siswa-siswa sekolah di Indonesia?

Dari beberapa contoh di atas terlihat bahwa setiap pertanyaan penelitian berkaitan dengan satu variabel atau lebih secara mandiri (bandingkan dengan masalah komparatif dan asosiatif). Peneliti yang bermaksud mengetahui kinerja Departemen pendidikan Nasional, sikap masyarakat terhadap perguruan tinggi berbadan hukum, efektivitas kebijakan MBS, tingkat produktivitas dan keuntungan finansial Unit Produksi pada sekolah-sekolah Kejuruan: minat baca dan lama belajar rata-rata per hari siswa-siswa sekolah di Indonesia adalah contoh penelitian deskriptif.

\section{Rumusan masalah komparatif}

Rumusan komparatif adalah rumusan masalah penelitian yang membandingkan keberadaan satu variabel atau lebih pada dua atau lebih sampel yang berbeda, atau pada waktu yang berbeda. Contoh rumusan masalah komparatif:

1) Adakah perbedaan prestasi belajar antara siswa dari sekolah negeri dan swasta? (variabel penelitian adalah prestasi belajar pada dua sampel yaitu sekolah negeri dan swasta).

2) Adakah perbedaan disiplin kerja guru antara sekolah di Kota dan di Desa? (satu variabel dua sampel).

3) Adakah perbedaan, motivasi belajar dan hasil belajar antara siswa yang berasal dari keluarga Guru, Pegawai Swasta, dan Pedagang? (dua variabel tiga sampel). 
4) Adakah perbedaan kompetensi profesional guru dan kepala sekolah antara SD, SMP, SLTA? (satu variabel untuk dua kelompok pada tiga sampel).

5) Adakah perbedaan daya tahan berdiri pelayan toko yang berasal dari Sekolah Menengah Kejuruan dan Sekolah Menengah Atas.

6) Adakah perbedaan produktivitas karya ilmiah antara Perguruan Tinggi Negeri dan Swasta (satu variabel dua sampel).

\section{Rumusan masalah asosiatif}

Rumusan masalah asosiatif adalah rumusan masalah penelitian yang bersifat menanyakan hubungan antara dua variabel atau lebih. Terdapat tiga bentuk hubungan yaitu: hubungan simetris, hubungan kausal, dan interaktif/resiprocal/timbal balik.

\section{a) Hubungan simetris}

Hubungan simetris adalah suatu hubungan antara dua variabel atau lebih yang kebetulan munculnya bersama. Jadi bukan kausal maupun interaktif, contoh rumusan masalahnya adalah sebagai berikut:

1) Adakah hubungan antara jumlah es yang terjual dengan jumlah kejahatan terhadap siswa sekolah? (variabel pertama adalah penjualan es dan kedua adalah kejahatan). Hal ini berarti yang menyebabkan jumlah kejahatan bukan karena es yang terjual. Mungkin logikanya adalah sebagai berikut. Pada saat es banyak terjual itu pada musim liburan sekolah, pada saat siswa-siswa banyak yang piknik ke tempat wisata. Karena banyak siswa yang piknik disitu banyak kejahatan.

2) Adakah jumlah hubungan antara rumah yang dekat rel kereta Api dengan jumlah anak?

3) Adakah hubungan antara warna rambut dengan kemampuan memimpin sekolah?

4) Adakah hubungan antara jumlah payung yang terjual dengan jumlah siswa sekolah?

5) Adakah hubungan antara banyaknya radio di pedesaan dengan jumlah penduduk yang sekolah?

Contoh judul penelitiannya: 
1) Hubungan antara jumlah es yang terjual dengan jumlah kejahatan terhadap siswa sekolah.

2) Hubungan antara rumah yang dekat rel kereta api dengan jumlah anak.

3) Hubungan antara warna rambut dengan kemampuan memimpin sekolah.

4) Hubungan antara jumlah payung yang terjual dengan jumlah siswa sekolah.

5) Hubungan antara banyaknya radio di pedesaan dengan jumlah penduduk yang sekolah.

\section{b) Hubungan kausal}

Hubungan kausal adalah hubungan yang bersifat sebab akibat. Jadi disini ada variabel independen (variabel yang mempengaruhi) dan dependen (dipengaruhi), contoh:

1) Adakah pengaruh pendidikan orang tua terhadap prestasi belajar anak? (pendidikan orang tua variabel independen dan prestasi belajar variabel dependen).

2) Seberapa besar pengaruh kepemimpinan kepala SMK terhadap kecepatan lulusan memperoleh pekerjaan? (kepemimpinan variabel independen dan kecepatan memperoleh pekerjaan variabel dependen).

3) Seberapa besar pengaruh tata ruang kelas terhadap efisiensi pembelajaran di SMA?

4) Seberapa besar pengaruh kurikulum, media pendidikan dan kualitas guru terhadap kualitas SDM yang dihasilkan dari suatu sekolah? (kurikulum, media, dan kualitas guru sebagai variabel independen dan kualitas SDM sebagai variabel dependen).

Contoh judul penelitiannya:

1) Pengaruh pendidikan orang tua terhadap prestasi belajar anak di SD Kabupaten Alengkapura.

2) Pengaruh kepemimpinan kepala sekolah terhadap kecepatan lulusan memperoleh pekerjaan pada SMK di provinsi Indrakila.

3) Pengaruh kurikulum, media pendidikan dan kualitas guru terhadap kualitas SDM yang dihasilkan dari suatu sekolah. 


\section{c) Hubungan interaktif/resiprocal/timbal balik}

Hubungan interaktif adalah hubungan yang saling mempengaruhi. Disini tidak diketahui mana variabel independen dan dependen. Contoh:

1) Hubungan antara motivasi dan prestasi belajar anak SD di kecamatan A. Disini dapat dinyatakan motivasi mempengaruhi prestasi tetapi juga prestasi dapat mempengaruhi motivasi.

2) Hubungan antara kecerdasan dengan kekayaan. Kecerdasan dapat menyebabkan kaya, demikian juga orang yang kaya dapat meningkatkan kecerdasan karena gizi terpenuhi.

Dalam penelitian kualitatif seperti yang dikemukakam, rumusan masalah yang merupakan fokus penelitian masih bersifat sementara dan akan berkembang setelah peneliti masuk lapangan atau situasi sosial tertentu. Namun demikian setiap peneliti baik peneliti kuantitatif maupuan kualitatif harus membuat rumusan masalah. Pertanyaan penelitian kualitatif dirumuskan dengan maksud untuk lebih memahami gejala yang masing remangremang, tidak teramati, dinamis dan kompleks, sehingga setelah diteliti menjadi lebih jelas apa yang ada dalam situasi sosial tersebut. Peneliti menggunakan pendekatan kualitatif, pada tahap awal penelitiannya, kemungkinan belum memiliki gambaran yang jelas tentang aspek-aspek masalah sambil mengumpulkan data. Proses ini disebut "emergent designt" (Lincoln dan Guba, 1985).

Merumuskan Masalah

\section{LEMBAR KERJA}

Petunjuk:

Mahasiswa mengkaji karakteristik masalah, kriteria pemilihan masalah penelitian dan cara-cara merumuskan masalah. Selanjutnya selesaikan soalsoal berikut.

1. Rumuskan pertanyaan penelitian (contoh) yang berkaitan dengan masalah berikut:
a. Kurikulum Pendidikan:
b. Proses Belajar Mengajar:
c. Perangkat Pembelajaran:
d. Media Pembelajaran:
e. Sumber Belajar: 
f. Siswa:

g. Guru:

h. Gaya Belajar:

i. Minat Belajar:

j. Prestasi Belajar:

\section{RUMUSAN TUJUAN PENELITIAN}

Tujuan suatu penelitian hendaknya diformulasikan secara spesifik dan jelas. Apabila tujuan itu belum spesifik dan jelas, maka sesungguhnya penelitian itu belum dapat dijalankan. Jika dipaksa menjalankannya hasilnya pasti tidak akan memuaskan. Dengan menentukan tujuan penelitian secara spesifik dan jelas peneliti juga dapat menjaring data apa saja yang benar-benar diperlukan.

Dalam banyak penelitian, malah penelitian seringkali dinyatakan dalam bentuk pernyataan tujuan yang menyiratkan pertanyaan. Pernyataan masalah ini biasanya dirumuskan dengan menggunakan kata-kata "Tujuan penelitian ini adalah ..." atau "Penelitian ini bertujuan untuk..." Misalnya, "Tujuan penelitian ini adalah untuk menyelidiki sikap dan berpikir keagamaan siswa dalam hubungannya dengan empat variabel siswa (jenis kelamin, umur, afiliasi keagamaan dan kemampuan akademik) yang tercermin dalam belajarnya di sekolah menengah pertama". Tujuan tersebut menggambarkan pertanyaan: Adakah hubungan antara jenis kelamin, umur, afiliasi keagamaan dan kemampuan akademik (sebagai variabel independen) dengan sikap dan berpikir keagamaan (sebagai variabel dependen) siswa sekolah menengah? Disamping itu, pernyataan tujuan tersebut memberi petunjuk tentang langkah khusus apa saja yang harus diputuskan untuk melakukan penyelidikan tentang permasalahan. Selanjutnya, juga menuntut peneliti untuk mengembangkan atau memilih instrumen yang sesuai guna mengukur sikap dan berpikir keagamaan serta kemampuan akademik. Peneliti juga dituntut untuk memilih sampel, mengumpulkan data, dan menggunakan teknik analisis statistik yang sesuai.

\section{KASUS}

1. Hasil wawancara (19 September 2019) peneliti dengan guru matematika Sekolah Menengah Theologia Kristen (SMTK) TNS Kelas X1. Mia diperoleh keterangan bahwa pada dasarnya siswa menganggap matematika itu sulit untuk dipelajari dibandingkan dengan mata pelajaran lain, kemampuan pemecahan masalahnya masih tergolong rendah yaitu sekitar 50\% dan model pembelajaran yang digunakan kurang bervariatif. 
Berdasarkan hasil observasi di atas, jawablah pertanyaan dibawah ini.

a. Rumuskan judul penelitian berdasarkan hasil wawancara di atas!

b. Tuliskan tujuan peneltian yang sesuai dengan rumusan judul penelitian tersebut!

c. Hal-hal apa saja yang dapat dikemukakan pada Latar Belakang Masalah? Jelaskan.

d. Bagaimana cara yang mudah dan sistematis dalam menganalisis masalah di latar belakang masalah, agar latar belakang masalah tidak melebar kemana-mana?

\section{RANGKUMAN}

Setiap penelitian baik jenis penelitian kuantitatif maupun kualitatif selalu berangkat dari masalah. Namun terdapat perbedaan yang mendasar antara "masalah" dalam penelitian kuantitatif dan "masalah" dalam penelitian kualitatif. Pada penelitian kuantitatif, masalah yang dipecahkan melalui penelitian harus jelas, spesifik, dan dianggap tidak berubah, tetapi dalam penelitian kualitatif, masalah yang dibawa oleh peneliti masih remang-remang, bahkan gelap, kompleks, dan dinamis. Oleh karena itu, masalah dalam penelitian kualitatif masih bersifat sementara, tentatif, dan akan berkembang atau diganti setelah peneliti berada dilapangan. Rumusan masalah berbeda dengan masalah. Jika masalah merupakan kesenjangan antara yang diharapkan dengan apa yang terjadi, maka rumusan masalah merupakan suatu pertanyaan yang akan dicarikan jawabannya melalui pengumpulan data. Namun demikian terdapat kaitan erat antara masalah dan rumusan masalah, karena setiap rumusan masalah penelitian harus didasarkan pada masalah. Rumusan masalah merupakan bentuk pertanyaan yang dapat memandu peneliti untuk mengumpulkan data di lapangan. Berdasarkan level of explanation suatu gejala, maka secara umum terdapat tiga bentuk rumusan masalah, yaitu rumusan masalah deskriptif, komparatif, dan asosiatif. Tujuan suatu penelitian hendaknya diformulasikan secara spesifik dan jelas. Apabila tujuan itu belum spesifik dan jelas, maka sesungguhnya penelitian itu belum dapat dijalankan. Jika dipaksa menjalankannya hasilnya pasti tidak akan memuaskan. Dengan menentukan tujuan penelitian secara spesifik dan jelas peneliti juga dapat menjaring data apa saja yang benar-benar diperlukan. 


\section{TUGAS}

1. Lakukan pengamatan dibawah ini!

a) Pergilah ke sekolah (SMP atau SMA) yang dekat dengan tempat tinggal Anda, kemudian melakukan wawancara, observasi dengan guru mata pelajaran Matematika dan siswa.

b) Pelajari masalah yang mereka alami pada proses atau hasil pembelajaran. Misalnya bagaimana cara siswa belajar, bagaimana minat, perhatian siswa terhadap pembelajaran, bagaimana guru mengajar dan menilai siswanya dan lain-lain.

c) Kumpulkan semua informasi terkait masalah yang ditemukan!

d) Buatlah latar belakang masalah penelitian dengan mengacu pada rencana judul dan uraian tabel di bawah.

e) Buatlah rumusan masalah dengan beberapa pertanyaan.

f) Buatlah tujuan penelitian dari rumusan masalah tersebut. 


\section{BAB 4 \\ VARIABEL PENELITIAN}

$\mathrm{D}$ alam rangka mendapatkan jawaban permasalahan yang menjadi konsen, peneliti harus memusatkan studinya pada variabel. Variabel mempunyai kaitan erat dengan teori. Teori adalah serangkaian konsep, definisi dan proposisi yang saling berkaitan dan bertujuan untuk memberikan gambaran yang sistematis tentang suatu fenomena. Gambaran yang sistematis itu dijabarkan dengan menghubungkan variabel yang satu dengan yang lainnya dengan tujuan untuk menjelaskan fenomena tersebut. Dalam praktik penelitian, sebelum diolah dengan teknik-teknik statistik variabel-variabel tersebut perlu didefinisikan secara operasional untuk memudahkan dalam mengidentifikasi dan melakukan pengukuran. Selanjutnya, definisi operasional itu akan menunjuk alat pengambil data mana yang cocok untuk digunakan. Pada bab ini akan dibicarakan tentang jenis-jenis variabel, dan cara mengidentifikasi variabel penelitian. Kemampuan akhir yang diharapkan setelah mahasiswa mempelajari bab ini yaitu:

1. Menemukan hubungan antar variabel

2. Menjabarkan macam-macam variabel

3. Menguraikan karakteristik masing-masing tipe variabel

4. Menganalisis faktor-faktor yang berpengaruh terhadap variabel

5. Menemukan variabel berdasarkan masalah yang ditemukan

\section{A. PENGERTIAN VARIABEL}

Jika ada pertanyaan tentang apa yang Anda teliti, maka jawabannya berkaitan dengan variabel penelitian. Kerlinger (1973) menyatakan bahwa variabel adalah konstruk atau sifat yang akan dipelajari. Contohnya tingkat aspirasi, penghasilan, pendidikan, status sosial, jenis kelamin, golongan gaji, produktivitas kerja, dan lain-lain. Dibagian lain Kerlinger menyatakan bahwa variabel dapat dikatakan sebagai suatu sifat yang diambil dari suatu nilai yang berbeda. Dengan demikian variabel itu merupakan suatu yang bervariasi. Kidder (1981) menyatakan bahwa variabel adalah suatu kualitas dimana peneliti mempelajari dan menarik kesimpulan darinya.

Dengan demikian variabel adalah obyek pengamatan, fenomena atau gejala yang diteliti. Variabel melekat pada unit yang diamati (juga disebut obyek pengamatan atau subyek). Unit adalah satuan yang memungkinkan observasi dapat dilakukan. Dalam penelitian pendidikan, unit yang banyak digunakan adalah manusia. Contoh variabel yang dapat diobservasi dari unit manusia 
adalah umur, tinggi badan, kemampuan membaca, jenis kelamin, indeks prestasi, IQ dan lain sebagainya.

Variabel-variabel itu mempunyai karakteristik yang bervariasi dari unitunit yang diamati. Variabel jenis kelamin, misalnya mempunyai dua variasi (pria dan wanita), sedang prestasi mempunyai variasi yang merentang dari sangat kurang sampai sangat baik/istimewa. Dalam penelitian kuantitatif, variasi karakteristik variabel itu dilambangkan dengan angka yang digunakan secara sistematis. Misalnya karakteristik pria dalam jenis kelamin diberi angka 1 dan wanita diberi angka 2. Dalam variabel prestasi belajar, variasi sangat kurang diberi angka 0 dan sangat baik atau istimewa diberi angka 100. Proses pemberian angka pada karakteristik variabel disebut pengukuran. Data adalah kumpulan hasil pengukuran terhadap variabel yang berisi informasi tentang karakterisik variabel.

Karena variabel sangat diperlukan dalam rangka mendapatkan jawaban dari permasalahan, maka peneliti perlu mengidentifikasi variabel apa saja yang akan dilibatkan dalam penelitiannya. Identifikasi variabel harus didasarkan pada permasalahan dan landasan teoritis. Berdasarkan permasalahan yang telah dirumuskan serta teori yang melandasinya, peneliti dapat menentukan variabel apa saja yang perlu diidentifikasi. Dengan demikian, jumlah variabel yang menjadi obyek pengamatan tergantung pada tingkat sofistifikasi masalah penelitian. Dalam masalah yang sederhana, misalnya penelitian yang bertujuan untuk mendeskripsikan prestasi belajar siswa, hanya ada satu variabel yakni prestasi belajar siswa. Dalam penelitian korelasional, minimal harus ada dua variabel. Semakin kompleks permasalahan yang menjadi fokus penelitian, semakin banyak variabel yang dilibatkan.

\section{B. HUBUNGAN ANTAR VARIABEL}

Tujuan inti dari penelitian ilmiah adalah mencari hubungan antar variabel. Sedangkan data-data yang diperoleh dari lapangan merupakan unsur-unsur yang mencantumkan Apakah variabel-variabel tersebut memiliki hubungan atau tidak. Dalam hubungan antar variabel ada beberapa jenis hubungan yang perlu diketahui yaitu:

\section{Hubungan simetris}

Variabel-variabel dikatakan mempunyai hubungan simetris jika variabel yang satu tidak dipengaruhi oleh variable lainnya. Terdapat empat kelompok hubungan simetris, yaitu: 
a) Kedua variabel merupakan indikator sebuah konsep yang sama.

Jumlah anak lahir yang hidup sama dengan tingkat kelahiran adalah dua indikator dari konsep fertilitas.

b) Kedua variabel merupakan akibat dari faktor yang sama.

Meningkatnya kebutuhan rekreasi dibarengi dengan bertambhnya jumlah kendaraan bermotor. Kedua variabel merupakan akibat dari peningkatan penghasilan.

c) Kedua variabel saling berkaitan secara fungsional. Contohnya dimana ada guru disana ada siswa.

d) Hubungan yang bersifat kebetulan semata.

Misalnya seorang bayi ditimbang lalu meninggal keesokan harinya.

\section{Hubungan timbal balik}

Hubungan timbal balik adalah hubungan di mana suatu variabel dapat menjadi sebab dan akibat dari variabel lainnya. Yang dimaksudkan adalah apabaila pada suatu waktu variabel $X$ mempengaruhi variabel $Y$, maka pada waktu lainnya variabel $Y$ mempengaruhi variabel $X$.

\section{Hubungan tidak simetris}

Satu variabel atau lebih mempengaruhi variabel yang lainnya. Ada enam tipe hubungan tidak simetris, yaitu:

a) Hubungan antara stimulus dan respon, misalnya pengaruh metode mengajar tertentu terhadap prestasi belajar siswa.

b) Hubungan antara disposisi dan respon, misalnya ada hubungan antara keinginan (disposisi) dengan frekuensi mencari pekerjaan (respon). Disposisi berada dalam diri seseorang.

c) Hubungan antara ciri individu dan disposisi atau tingkah laku. Ciri individu relatif tidak berubah dan tidak dipengaruhi oleh lingkungan.

d) Hubungan antara prekondisi yang perlu dengan akibat tertentu, contohnya agar warga Negara dapat menyatakan aspirasinya dengan jujur diperlukan jaminan pemerintah untuk melindungi kebebasan pers.

e) Hubungan yang permanent antara dua variable, jika yang satu berubah maka variable yang lain ikut berubah. Misalnya semakin tinggi jabatan seseorang, akan semakin besar tanggung jawab yang dipikulnya. 
f) Hubungan antara tujuan dan cara, contohnya hubungan jumlah belajar dengan nilai ujian yang diperoleh.

\section{MACAM-MACAM VARIABEL}

Menurut hubungan antara satu variabel dengan variabel yang lain maka macam-macam variabel dalam penelitian dapat dibedakan menjadi:

\section{Variabel Independen}

Variabel ini sering disebut sebagai variabel stimulus, prediktor, antecedent. Dalam bahasa Indonesia variabel bebas. Variabel bebas adalah merupakan variabel yang mempengaruhi atau yang menjadi sebabi perubahannya atau timbulnya variabel dependen (terikat). Contohnya dalam bidang pendidikan adalah prestasi belajar sebagai pokok persoalannya. Variabel terikat tersebut tergantung dari banyak faktor yang mempengaruhinya. Faktor-faktor yang mempengaruhi itu disebut varibel bebas.

\section{Variabel Dependen}

Variabel ini disebut sebagai variabel output, kriteria, konsekuen. Dalam bahasa Indonesia sering disebut sebagai variabel terikat. Variabel terikat merupakan variabel yang dipengaruhi atau yang menjadi akibat, karena adanya variabel bebas. Misalnya, jika variabel terikatnya adalah prestasi belajar, maka variabel bebasnya dapat berupa motivasi mengajar. Disamping metode mengajar, masih banyak variabel lain yang mempengaruhi prestasi belajar.

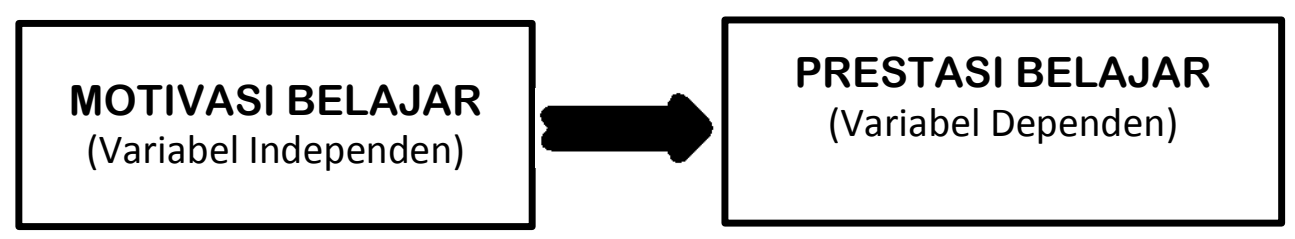

Gambar 4.1. Contoh hubungan variabel Independen - Dependen (Sugiyono, 2017)

\section{Variabel Kontrol}

Variabel yang mempengaruhi (memperkuat dan memperlemah) hubungan antara variabel independen - dependen. Variabel ini disebut juga sebagai variabel independen kedua. Misalnya, hubungan semangat belajar dan hasil belajar siswa akan meningkat jika guru mampu menciptakan iklim kelas yang meyenangkan, namun akan menurun jika guru tidak mampu menciptakan iklim belajar yang menyenangkan. Pada 
bagian ini guru mampu menciptakan iklim yang menyenangkan adalah variabel moderator yang memperkuat, sedangkan guru tidak mampu menciptakan iklim, yang menyenangkan adalah variabel moderator yang memperlemah.

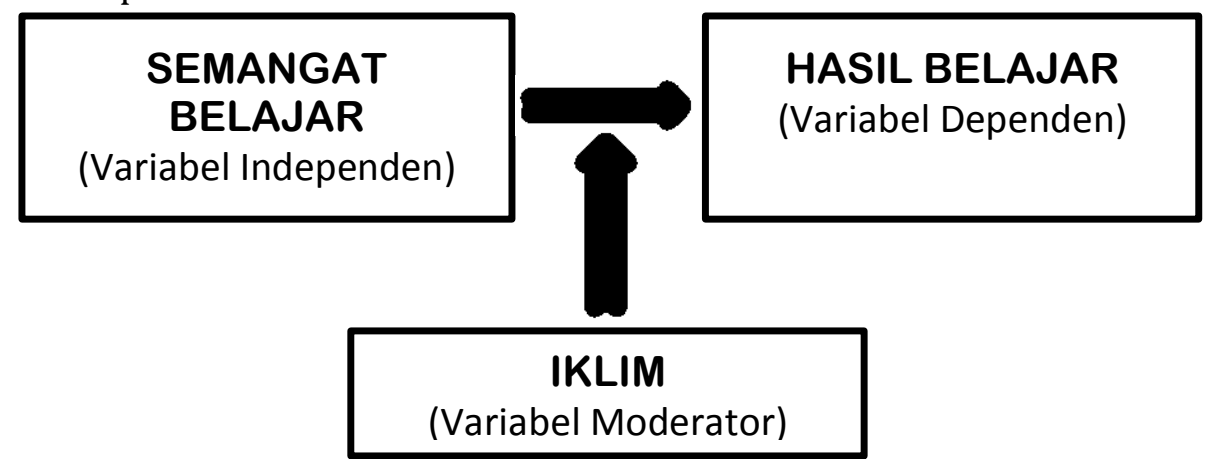

Gambar 4.2. Contoh hubungan variabel Independen - Moderator, Dependen (Sugiyono, 2017)

\section{Variabel Intervening}

Tuckman (1988) menyatakan "an intervening is that factor that theorectically affect the observed phenomenom but cannot be seen, measure, or manipulate". Variabel intervening adalah variabel yang secara teoritis mempengaruhi hubungan antara variabel independen dengan dependen menjadi hubungan yang tidak langsung dan tidak dapat diamati dan diukur. Variabel ini merupakan variabel penyela/antara yang terletak diantara variabel independen dan dependen, sehingga variabel independen tidak langsung mempengaruhi berubahnya atau timbulnya variabel dependen. Misalnya terdapat pengaruh jumlah biaya pendidikan yang dikeluarkan oleh orang tua terhadap gaya hidup mahasiswa dan akan berimbas pada IPK mahasiswa tersebut.

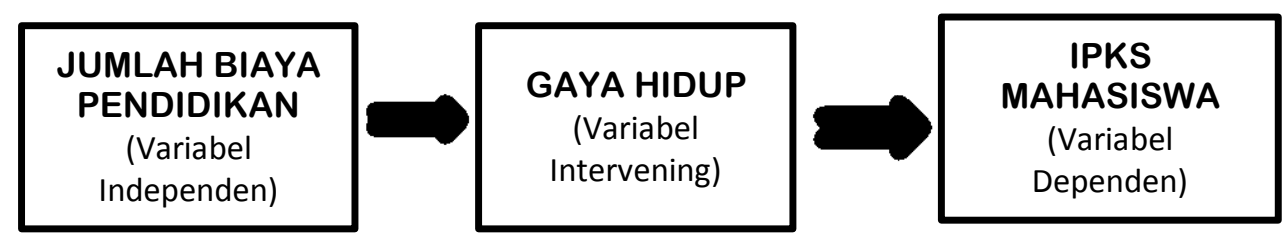

Gambar 4.3. Contoh hubungan variabel Independen - Moderator, Dependen (Sugiyono, 2017)

Kedudukan dari variabel independen, dependen, moderator, intervening atau variabel yang lain, harus dilihat konteksnya dengan dilandasi dengan konsep teoritis yang mendasari maupun hasil dari pengamatan yang empiris. 
Untuk itu sebelum peneliti memilih variabel apa yang akan diteliti perlu melakukan kajian teoritis, dan melakukan studi pendahuluan terlebih dahulu pada obyek yang akan diteliti. Jangan sampai terjadi membuat rancangan penelitian dilakukan di belakang meja, dan tanpa mengetahui terlebih dahulu permasalahan yang ada di obyek penelitian. Sering terjadi, rumusan masalah penelitian dibuat tanpa melalui studi pendahuluan ke obyek penelitian, sehingga setelah dirumuskan ternyata masalah itu tidak menjadi masalah pada obyek penelitian. Setelah masalah dapat difahami dengan jelas dan dikaji secara teoritis, maka peneliti dapat menentukan variabel-variabel penelitiannya.

Pada kenyataannya, gejala-gejala sosial itu meliputi berbagai macam variabel saling terkait secara simultan baik variabel independen, dependen, moderator, dan intervening, sehingga penelitian yang baik akan mengamati semua variabel tersebut. Tetapi karena adanya keterbatasan dalam berbagai hal, maka peneliti sering hanya memfokuskan pada beberapa variabel penelitian saja, yaitu pada variabel independen dan dependen. Dalam penelitian kualitatif hubungan antara semua variabel tersebut akan diamati, karena penelitian kualitatif berasumsi bahwa gejala itu tidak dapat diklasifikasikan, tetapi merupakan suatu kesatuan yang tidak dapat dipisahkan.

\section{PARADIGMA PENELITIAN}

Dalam penelitian kuantitatif/positivistik, yang dilandasai pada suatu asumsi bahwa suatu gelaja itu dapat diklasifikasikan, dan hubungan gejala bersifat kausal (sebab akibat), maka peneliti dapat melakukan penelitian dengan memfokuskan kepada beberapa variabel saja. Pola hubungan antara variabel yang akan diteliti tersebut selanjutnya disebut sebagai paradigma penelitian.

Jadi paradigma penelitian dalam hal ini diartikan sebagai pola pikir yang menunjukan hubungan antara variabel yang akan diteliti sekaligus mencerminkan jenis dan jumlah rumusan masalah yang perlu dijawab melalui penelitian, teori yang digunakan untuk merumuskan hipotesis, jenis dan jumlah hipotesis, dan teknik analisis statistik yang akan digunakan. Berdasarkan hal ini maka bentuk-bentuk paradigma atau model penelitian kuantitatif khususnya untuk penelitian survey seperti gambar berikut. 


\section{1) Paradigma sederhana}

Paradigma penelitian ini terdiri atas satu variabel independen dan dependen. Hal ini dapat digambarkan seperti gambar berikut.

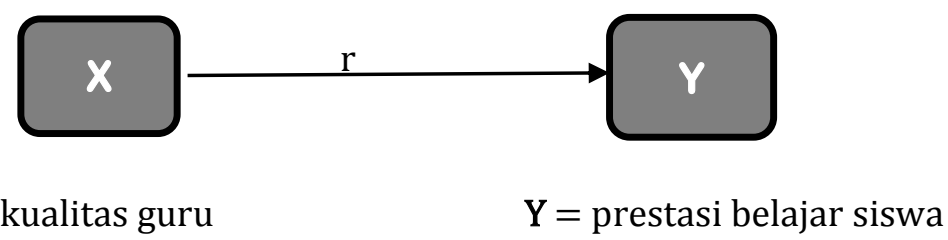

$$
\mathrm{X}=\text { kualitas guru } \quad \mathrm{Y}=\text { prestasi belajar siswa }
$$

Gambar 4.4. Paradigma sederhana (Sugiyono, 2017)

Berdasarkan paradigma tersebut, maka dapat ditentukan:

a. Jumlah rumusan masalah deskriptif ada dua, dan asosiatif ada satu yaitu:

a) Rumusan masalah deskriptif (dua)

i. Bagaimana $\mathbf{X}$ ? kualitas guru

ii. Bagaimana Y? prestasi belajar siswa

b) Rumusan masalah asosiatif (satu)

"bagaiman hubungan atau pengaruh kualitas alat dengan kualitas barangyang dihasilkan".

b. Teori yang digunakan ada dua, yaitu teori tantang media pendidikan dan prestasi belajar siswa.

c. Hipotesis yang dirumuskan ada dua macam hipotesis deskriptif dan hipotesis asosiatif (hipotesis deskriptif sering tidak dirumuskan).

a) Dua hipotesis deskriptif: (jarang dirumuskan dalam penelitian)

i. Kualitas media yang digunakan oleh lembaga pendidikan tersebut telah mencapai $70 \%$ baik.

ii. Prestasi belajar siswa lembaga pendidikan tersbut telah mencapai $90 \%$ dari yang diharapkan.

b) Hipotesis asosiatif:

Ada hubungan yang positif dan signifikan antara kualitas media pendidikan dengan prestasi belajar siswa. Hal ini berarti bila kualitas media pendidikan ditingkatkan, maka prestasi belajar siswa akan meningkat pada gradiasi yang tinggi (kata signifikan hanya digunakan apabila hasil uji hipotesis akan 
digeneralisasikan ke populasi dimana sampel tersebut diambi).

d. Teknik analisis data

Berdasarkan rumusan masalah dan hipotesis tersebut, maka dapat dengan mudah ditentukan teknik statistik yang digunakan untuk analisis data dan menguji hipotesis.

a) Untuk dua hipotesis deskriptif, bila datanya berbentuk interval dan ratio, maka pengujian hipotesis menggunakan $t$-test one sampel.

b) Untuk hipotesis asosiatif, bila data ke dua variabel berbentuk interval atau ratio, maka menggunakan teknik Statistika Korelasi Product Moment (lihat pedoman umum untuk memilih teknik statistik untuk pengujian hipotesis).

\section{2) Paradigma sederhana berurutan}

Paradigma ini terdapat lebih dari dua variabel tetapi hubungannya masih sederhana. Seperti yang ditunjukan pada gambar dibawah ini.

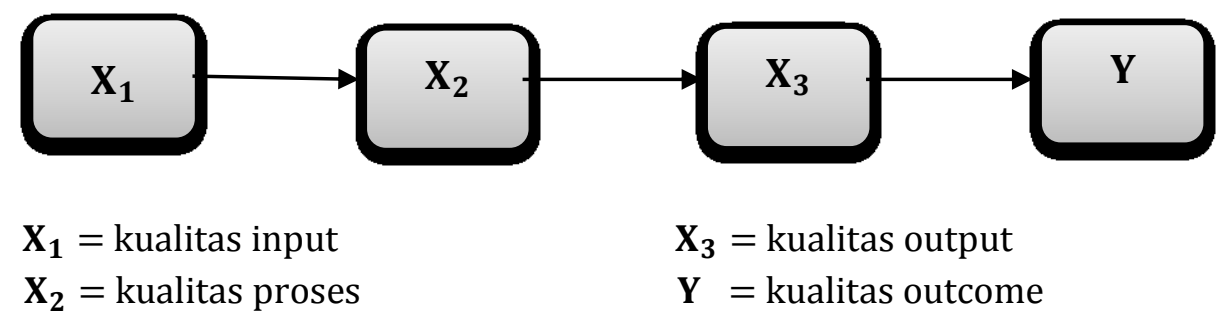

Gambar 4.5. Paradigma sederhana yang menunjukan hubungan antara satu variabel Independen dengan satu variabel Dependen secara berurutan (Sugiyono, 2017)

Untuk mencari hubungan antar variabel variabel ( $\mathbf{X}_{\mathbf{1}}$ dengan $\mathbf{X}_{2}$; $\mathbf{X}_{\mathbf{2}}$ dengan $\mathbf{X}_{\mathbf{3}}$; dan $\mathbf{X}_{\mathbf{3}}$ dengan $\mathbf{Y}$ ) digunakan teknik korelasi sederhana. Naik turun harga $\mathbf{Y}$ dapat dipredikdsi melalui persamaan regresi $\mathrm{Y}$ atas $\mathbf{X}_{\mathbf{3}}$, dengan persamaan $\mathbf{Y}=\mathbf{a}+\mathbf{b} \mathbf{X}_{\mathbf{3}}$. 
3) Paradigma ganda dengan dua variabel independen

Dalam paradigma ini terdapat dua variabel independen dan satu dependen. Dalam paradigma ini terdapat 3 rumusan masalah deskriptif, dan 4 rumusan masalah asosiatif (3 korelasi sederhana dan 1 korelasi ganda).

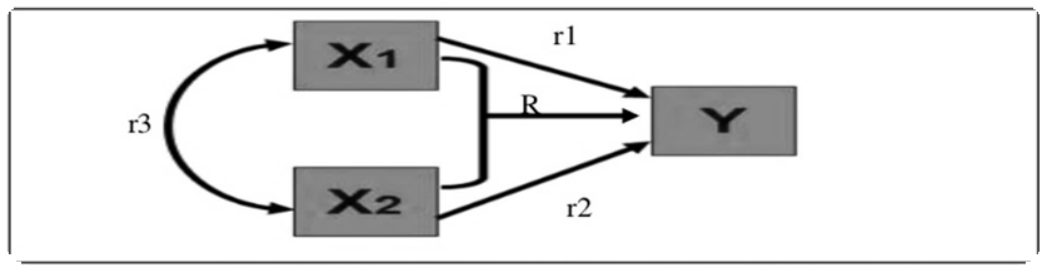

$$
\begin{aligned}
\mathbf{X}_{\mathbf{1}} & =\text { kompetensi guru } \\
\mathbf{X}_{\mathbf{2}} & =\text { lingkungan sekolah }
\end{aligned}
$$

Gambar 4.6. Paradigma ganda dengan dua variabel Independen $\mathrm{X}_{1}$ dan hubungan $X_{2}$, dan satu variabel Dependen $Y$ (Sugiyono, 2017)

Untuk mencari hubungan $\mathbf{X}_{\mathbf{1}}$ dengan $\mathbf{Y}$ dan $\mathbf{X}_{\mathbf{2}}$ dengan $\mathbf{Y}$, menggunakan teknik korelasi sederhana, untuk mencari hubungan $\mathbf{X}_{\mathbf{1}}$ dengan $\mathbf{X}_{\mathbf{2}}$ secara bersama-sama terhadap $\mathbf{Y}$ menggunakan korelasi ganda.

\section{4) Paradigma ganda dengan tiga variabel independen}

Pada paradigma ini terdapat tiga variabel independen $\left(\mathbf{X}_{\mathbf{1}}, \mathbf{X}_{\mathbf{2}}, \mathbf{X}_{\mathbf{3}}\right)$ dan satu dependen (Y). Rumusan masalah deskriptif ada 4 dan rumusan masalah asosiatif (hubungan) untuk yang sederhana ada 6 dan yang ganda minimal 1.

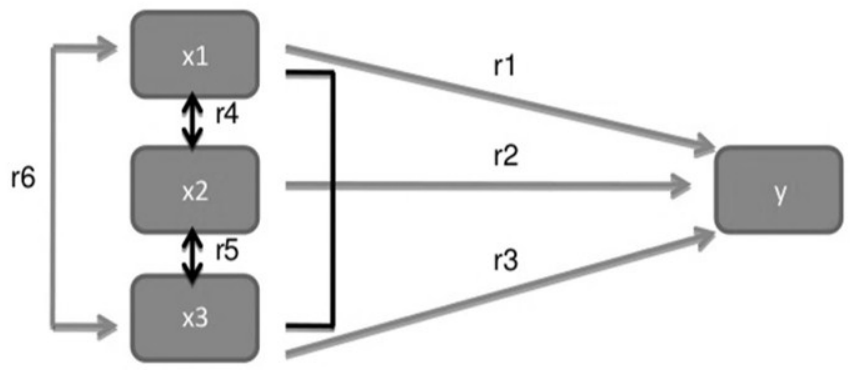

Gambar 4.7. Paradigma ganda dengan tiga variabel Independen

(Sugiyono, 2017) 
$\mathrm{r}_{2}=$ berhimpit dengan $\mathrm{R}$

$$
\begin{array}{rlrl}
\mathbf{X}_{1} & =\text { kualitas mesin } & & \mathbf{X}_{\mathbf{3}}=\text { etos belajar } \\
\mathbf{X}_{\mathbf{2}} & =\text { pengalaman kerja } & \mathbf{Y}=\text { produktivitas kerja }
\end{array}
$$

Gambar di atas adalah paradigma ganda dengan tiga variabel independen yaitu $\mathbf{X}_{1}, \mathbf{X}_{2}$, dan $\mathbf{X}_{3}$. Untuk mencari besarnya hubungan antara $\mathbf{X}_{\mathbf{1}}$ dengan $\mathbf{Y} ; \mathbf{X}_{\mathbf{2}}$ dengan $\mathbf{Y} ; \mathbf{X}_{\mathbf{3}}$ dengan $\mathbf{Y} ; \mathbf{X}_{\mathbf{1}}$ dengan $\mathbf{X}_{\mathbf{2}} ; \mathbf{X}_{\mathbf{2}}$ dengan $\mathbf{X}_{\mathbf{3}}$ dan $\mathbf{X}_{\mathbf{1}}$ dengan $\mathbf{X}_{\mathbf{3}}$ dapat menggunakan korelasi sederhana. Untuk mencari besarnya hubungan antara $\mathbf{X}_{\mathbf{1}}$ secara bersama-sama dengan $\mathbf{X}_{\mathbf{2}}$ dan $\mathbf{X}_{\mathbf{3}}$ terhadap $\mathbf{Y}$ digunakan korelasi ganda. Regresi sederhana, dan ganda serta korelasi parsial dapat digunakan untuk dianalisis dalam paradigma ini.

5) Paradima ganda dengan dua variabel dependen

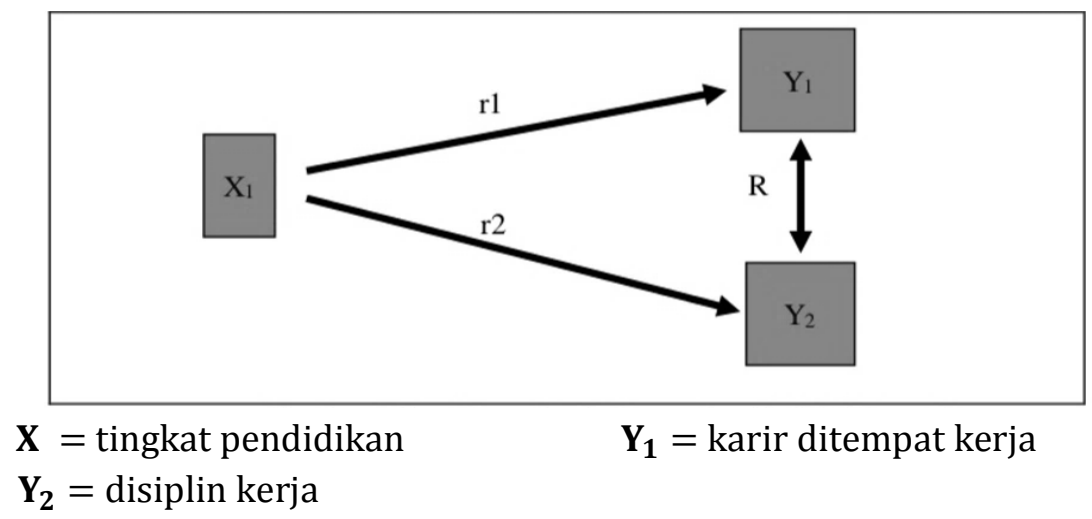

Gambar 4.8. Paradigma ganda dengan satu variabel Independen dan dua Dependen (Sugiyono, 2017)

Untuk mencari besarnya hubungan antara $X$ dan $Y_{1}$, dan $X$ dengan $Y_{2}$ digunakan teknik korelasi sederhana. Demikian juga untuk $Y_{1}$ dengan $Y_{2}$. Analisis regresi juga dapat digunakan disini.

\section{6) Paradigma Ganda dengan Dua Variabel Independen dan Dua Depeneden}

Paradigma ini terdapat dua variabel independen $\left(\mathrm{X}_{1}, \mathrm{X}_{2}\right)$ dan dua variabel dependen $\left(\mathrm{Y}_{1}\right.$ dan $\left.\mathrm{Y}_{2}\right)$. Terdapat 4 rumusan masalah deskripstif, dan enam rumusan masalah hubungan sederhana. Korelasi dan regresi ganda juga dapat digunakan unuk menganalisisi hubungan antar variabel secara simultan. 


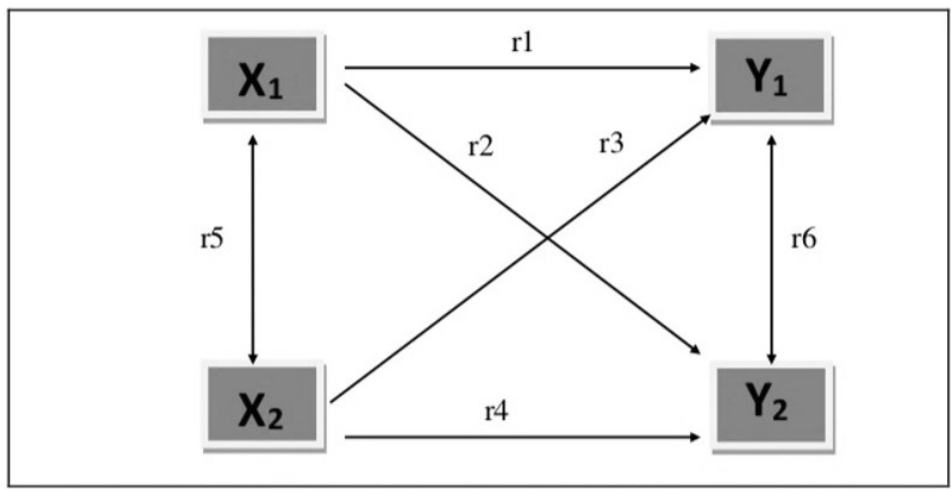

$$
\begin{aligned}
\mathbf{X}_{1}=\text { keindahan kampus } & \mathbf{Y}_{1}=\text { jumlah pendaftar } \\
\mathbf{X}_{2}=\text { pelayanan sekolah } & \mathbf{Y}_{2}=\text { kepuasan pelayanan }
\end{aligned}
$$

Gambar 4.9. Paradigma ganda dengan satu variabel Independen dan dua Dependen (Sugiyono, 2017)

Hubungan antar variabel $\mathbf{r}_{\mathbf{1}}, \mathbf{r}_{2}, \mathbf{r}_{3}, \mathbf{r}_{\mathbf{4}}, \mathbf{r}_{5}$, dan $\mathbf{r}_{\mathbf{6}}$ dapat dianalisis dengan korelasi sederhana. Hubungan antara $X_{1}$ bersama-sama dengan $\mathbf{X}_{\mathbf{2}}$ terhadap $\mathbf{Y}_{\mathbf{1}}$ dan $\mathbf{X}_{\mathbf{1}}$ dan $\mathbf{X}_{\mathbf{2}}$ bersama-sama terhadap $\mathbf{Y}_{\mathbf{2}}$ dapat dianalisis dengan korelasi ganda. Analisis regresi sederhana maupun ganda dapat juga digunakan untuk meprediksi jumlah tiket yang terjual dan kepuasan penumpang Kereta Api.

Variabel Penelitian

\section{LEMBAR KERJA}

Petunjuk:

Mahasiswa telah merumuskan pertanyaan penelitian pada Lembar Kerja Bab Masalah Penelitian. Selanjutnya selesaikan soal-soal berikut.

1. Buatlah klasifikasi variabel dari masalah tersebut untuk menentukan jenis data yang diperlukan.
a.
b.
c.
d.
e.
f.
g.
h. 


\section{RANGKUMAN}

Variabel sangat diperlukan dalam rangka mendapatkan jawaban dari permasalahan, maka peneliti perlu mengidentifikasi variabel apa saja yang akan dilibatkan dalam penelitiannya. Identifikasi variabel harus didasarkan pada permasalahan dan landasan teoritis. Berdasarkan permasalahan yang telah dirumuskan serta teori yang melandasinya, peneliti dapat menentukan variabel apa saja yang perlu diidentifikasi. Tujuan inti dari penelitian ilmiah adalah mencari hubungan antar variabel. Sedangkan data-data yang diperoleh dari lapangan merupakan unsur-unsur yang mencantumkan Apakah variabelvariabel tersebut memiliki hubungan atau tidak. Dalam hubungan antar variabel ada beberapa jenis hubungan yang perlu diketahui yaitu: hubungan simetris, hubungan timbal balik, hubungan tidak simetris. Menurut hubungan antara satu variabel dengan variabel yang lain maka macam-macam variabel dalam penelitian dapat dibedakan menjadi: variabel independen, variabel dependen, variabel kontrol dan variabel intervening.

\section{TUGAS}

1. Uraikan secara jelas analisis Anda mengenai definisi, fungsi, dan bagaimana menyusun definisi operasional penelitian. Buatlah dalam bentuk makalah dengan bagian pokok yang harus ada adalah Pendahuluan, Isi, dan Kesimpulan.

2. Berdasarkan rumusan masalah penelitian yang dibuat pada tugas bab Masalah Penelitian, langkah berikutnya menentukan variabelvariabel dan mencari hubungan antar variabel penelitian tersebut. 


\section{BAB 5 STUDI KEPUSTAKAAN}

Penelitian pendidikan tidak dapat dipisahkan dengan pengetahuan kependidikan, karena ia merupakan alat untuk mendapatkan informasi baru yang berguna untuk mengisi kekosongan atau menguji pengetahuan yang telah ada. Oleh karena itu, agar dapat diketahui bagaimana hubungan dan dimana posisi pengetahuan yang diperoleh dari penelitian dalam kaitannya dengan pengetahuan yang telah ada, perlu tinjauan terhadap bahan-bahan pustaka yang relevan dengan topik masalah yang diangkat. Tanpa studi pustaka, akan sulit membuat sebuah pokok dari ilmu pengetahuan yang diterima dari sebuah topik kependidikan. Studi kepustakaan dilakukan oleh setiap peneliti dengan tujuan yang utama yaitu mencari dasar pijakan atau fondasi untuk memperoleh dan membangun landasan teori, kerangka berpikir dan menentukan dugaan sementara atau disebut hipotesis penelitian. Hipotesis adalah pernyataan tentatif yang merupakan dugaan atau terkaan tentang apa yang kita amati dalam usaha untuk memahaminya. Hipotesis dapat diturunkan dari teori, akan tetapi ada kalanya sukar untuk membedakan secara tegas antara teori dan hipotesis. Biasanya suatu teori jarang secara langsung diuji kebenarannya, yang diuji adalah hipotesis. Hipotesis diturunkan dari teori itu. Dalam suatu penelitian, hipotesis sangat penting untuk memperjelas masalah yang sedang diteliti. Tanpa hipotesis, seorang peneliti seringkali membuangbuang waktu dan tenaga untuk tujuan yang tidak jelas. Hipotesis harus ditentukan sebelum melakukan langkah-langkah penelitian. Pada bab ini akan dibicarakan tentang landasan teori, kerangka berpikir, dan pengajuan hipotesis. Kemampuan akhir yang diharapkan setelah mahasiswa mempelajari bab ini yaitu:

1. Menganalisis landasan teori

2. Memadukan sumber-sumber literatur yang relevan

3. Menyusun landasan teori untuk keperluan penelitian

4. Menganalisis kekeliruan dalam pengujian hipotesis

5. Mengajukan hipotesis penelitian

\section{A. LANDASAN TEORI}

Setelah masalah penelitian dirumuskan, maka langkah kedua dalam proses penelitian adalah adalah mencari teori-teori, konsep-konsep dan generalisasigeneralisasi hasil penelitian yang dapat dijadikan sebagai landasan teoritis. Landasan-landasan teori ini perlu ditegakan agar penelitian itu mempunyai dasar yang kokoh, dan bukan sekedar perbuatan coba-coba (trial and error). 
Adanya landasan teoritis ini merupakan ciri bahwa penelitian itu merupakan cara ilmiah untuk mendapatkan data.

Setiap penelitian selalu menggunakan teori. Seperti yang dinyatakan oleh Neumen (2003) "Researchers use theory differently in various types of research, but some type of theory is present in most social reseacrh". Para peneliti menggunakan teori berbeda sesuai tipe penelitian, tetapi beberapa teori disajikan atau digunakan pada hampir semua penelitian ilmu sosial. Kerilinger (1978) mengemukakan bahwa "Theory is a set of interrelated construct (concepts), definitions, and proposition that present a systematic view of phenomena by specifying relations among variables, with purpose of explaining and predicting the phenomena". Teori adalah seperangkat konstruk (konsep), definisi, dan proporsi yang berfungsi untuk melihat fenomena secara sistematik, melalui spesifikasi hubungan antar variabel, sehingga dapat berguna untuk menjelaskan dan meramalkan fenomena.

Coorper and Schindler (2003) mengemukakan bahwa $A$ theory is a set of systematically interrelated concepts, defninition, and proposition that are advanced to explain and predict phenomena (fact). Teori adalah seperangkat konse, definisi dan proporsi yang tersusun secara sistematis sehingga dapat digunakan untuk menjelaskan dan meramalkan fenomena.

Selanjutnya Sitirahayu Haditono (1999), menyatakan bahwa menyatakan bahwa suatu teori akan memperoleh arti penting, bila dia lebih banyak dapat melukiskan, menerangkan, dan meramalkan gejala yang ada.

Mark 1963, dalam (Sitirahayu Haditono, 1999), membedakan adanya tiga macam teori. Ketiga teori yang dimaksud ini berhubungan dengan empiris. Dengan demikian dapat dibedakan antara lain:

1) Teori yang deduktif: memberi keterangan yang dimulai dari suatu perkiraan atau pikiran spekulatif tertentu ke arah data akan diterangkan.

2) Teori yang induktif: menerangkan dari data ke arah teori. Dalam bentuk ekstrem titik pandang yang positivistik ini dijumpai pada kaum behaviorist.

3) Teori fungsional: disini nampak suatu interaksi pengaruh antara data dan perkiraaan teeoritis, yaitu data mempengaruhi pembentukan teori, dan pembentukan teori kembali mempengaruhi data. 
Berdasarkan tiga pandangan ini dapat disimpulkan bahwa teori dapat dipandang sebagai berikut:

1) Teori menunjuk pada sekelompok hukum yang tersusun secara logis. Hukum-hukum ini biasanya sifat hubungan yang deduktif. Suatu hukum menunjukan suatu hubungan antara variabel-variabel empiris yang bersifat ajeg dapat diramal sebelumnya.

2) Suatu teori juga dapat merupakan suatu rangkuman tertulis mengenai suatu kelompok hukum yang diproleh secara empiris dalam suatu bidang tertentu. Disini orang mulai dari data yang diperoleh dan dari data yang diperoleh itu datang suatu konsep yang teoritis (induktif).

3) Suatu teori juga dapat menunjuk pada suatu cara menerangkan yang menggeneralisasi. Disini biasanya terdapat hubungan yang fungsional antara data dan pendapat yang teoritis.

Berdasarkan data tersebut di atas secara umum dapat ditarik kesimpulan bahwa, suatu teori adalah suatu konseptualisasi yang umum. Konseptualisasi atau sistem pengertian ini diperoleh melalui, jalan yang sistematis. Suatu teori harus dapat diuji kebenarannya, bila tidak, dia bukan suatu teori.

\section{Kegunaan Teori dalam Penelitian}

Cooper and Schindler (2003), menyatakan bahwa kegunaan teori dalam penelitian ini adalah:

1) Theory norrows the range of fact we need to study (teori mempersempit/membatasi ruang atau kawasan dari fakta yang akan kita pelajari).

2) Theory suggest which research approachesare likely to yield the greatesmearning (teori menyarankan pendekatan penelitian yang mungkin untuk menghasilkan makna terbesar).

3) Theory suggest a system for the research to impose on data in order to classify them in the most meaningful way (teori menyarankan sistem penelitian untuk memaksakan pada data dalam rangka mengklasifikasikan mereka dalam cara yang paling bermakna).

4) Theory summarizes what is known about object of study and states the uniformmities that lie beyond immediate observation (teori merangkum apa yang diketahui tentang objek studi dan menyatakan keseragaman yang berada di luar pengamatan langsung). 
5) Theory can be used to predict further fact that should be found (teori dapat digunakan untuk memprediksi fakta lanjut yang harus ditemukan).

Semua penelitian bersifat ilmiah, oleh karena itu semua peneliti harus berbekal teori. Dalam penelitian kuantitatif, teori yang digunakan harus sudah jelas, karena teori disini alan berfungsi untuk memperjelas masalah yang diteliti, sebagai dasar untuk merumuskan hipotesis dan sebagai referensi untuk menyusun instrumen penelitian. Oleh karena itu landasan teori dalam proposal penelitian kuantitatif harus sudah jelas teori apa yang akan dipakai.

Dalam kaitannya dengan kegiatan penelitian, maka fungsi teori yang pertama digunakan untuk memperjelas dan mempertajam ruang lingkup atau konstruk variabel yang akan diteliti. Fungsi teori yang kedua (prediksi dan pemandu untuk menemukan fakta) adalah untuk merumuskan hipotesis dan menyusun instrumen penelitian, karena pada dasarnya hipotesis itu merupakan pertanyaan yang bersifat prediktif. Selanjutnya fungsi teori yang ketiga (kontrol) digunakan mencandra dan membahas hasil penelitian sehingga selanjutnya digunakan untuk memberikan saran dalam upaya pemecahan masalah. Dalam landasan teori perlu dikemukakan deskripsi teori dan kerangka berpikir sehingga selanjutnya dapat merumuskan hipotesis dan instrumen penelitian.

\section{Deskripsi Teori}

Deskripsi teori dalam suatu penelitian merupakan usulan sistematis tentang teori dan hasil-hasil penelitian yang relevan dengan variabel yang diteliti. Berapa jumlah kelompok teori yang perlu dikemukakan/dideskripsikan akan tergantung pada jumlah variabel yang diteliti. Semakin banyak variabel yang diteliti, maka semakin banyak teori yang perlu dikemukakan.

Deskripsi teori paling tidak berisi tentang penjelasan terhadap variabelvariabel yang diteliti melalui pendefinisian dan uraian yang lengkap dan mendalam dari berbagai referensi, sehingga ruang lingkup kedudukan dan prediksi terhadap hubungan antar variabel yang akan diteliti menjadi lebih jelas dan terarah.

Hasil penelitian yang relevan bukan berarti sama dengan yang akan diteliti, tetapi masih dalam lingkup yang sama. Secara teknis hasil penelitian yang relevan degan apa yang akan diteliti dapat dilihat dari permasalahan yang diteliti, waktu penelitian, sampel penelitian, metode peneltian, analisis dan kesimpulan. Misalnya peneliti yang terdahulu, melakukan penelitian tentang tingkat penjualan jenis kendaraan bermotor di Masohi. Jadi hanya berbeda 
lokasi saja. Peneliti yang kedua ini dapat menggunakan referensi hasil penelitian yang pertama.

Langkah-langkah untuk dapat melakukan pendeskripsian teori adalah:

1) Tetapkan nama variabel yang diteliti, dan jumlah variabelnya.

2) Cari sumber-sumber bacaan (buku, kamus, ensiklopedia, jurnal ilmiah, laporan penelitian, Skripsi, Tesis, Disertasi) yang sebanyakbanyaknya dan relevan dengan setiap variabel yang diteliti.

3) Lihat daftar isi setiap buku dan pilih topik yang relevan dengan setiap variabel yang akan diteliti. (untuk referensi yang berbentuk laporan penelitian, lihat judul penelitian, permasalahan, teori yang digunakan, tempat penelitian, sampel sumber data, teknik pengumpulan data, analisis, kesimpulan dan saran yang diberikan).

4) Cari definisi setiap variabel yang akan diteliti pada setiap sumber bacaan, bandingkan antara satu sumber dengan sumber yang lain, dan pilih definisi yang sesuai dengan penelitian yang akan dilakukan.

5) Baca seluruh isi topik buku yang sesuai dengan variabel yang akan diteliti, lakukan analisa, renungkan dan buatlah rumusan dengan bahasa sendiri tentang isi setiap sumber data yang dibaca.

6) Deskripsikan teori-teori yang telah dibaca dari berbagai sumber dalam bentuk tulisan dengan bahasa sendiri. Sumber-sumber bacaan yang dikutip atau yang digunakan sebagai landasan untuk mendeskripsikan teori harus dicantumkan.

\section{B. KERANGKA BERPIKIR}

Uma Sekaran dalam bukunya Bussiness Research (1992) mengemukakan bahwa, kerangka berpikir merupakan model konseptual tentang bagaimana teori berhubungan dengan berbagai faktor yang telah diidentifikasikan sebagai masalah yang penting.

Menurut (Sukardi, 2003) ada banyak cara yang bisa kita gunakan untuk sebagai bahan studi kepustakaan. Bagi sebagian orang bisa menggunakan sumber data primer ( rimary sources) yang berasal dari hasil-hasil penelitian seperti berikut:

\section{Jurnal penelitian}

Sumber utama dan mempunyai nilai sangat penting dibanding sumbersumber informasi lainnya adalah jurnal penelitian. Banyak ragam tentang jurnal penelitian sebanyak bidang pengetahuan yang ada dan digeluti oleh para peneliti. Dari bermacam-macam jurnal penelitian ini termasuk diantaranya: Jurnal Karya Pendidikan Matematika diterbitkan oleh 
Universitas Muhammadiyah Semarang, Journal On Mathematics Education diterbitkan oleh Universitas Sriwijaya, Jurnal Kamboti: Jurnal Ilmu Sosial dan Humaniora diterbitkan oleh Lembaga Layanan Pendidikan Tinggi (LLDikti) Wilayah XII, Jurnal Dinamika Pendidikan diterbitkan oleh Universitas Negeri Semarang, dan masih banyak lagi. Dalam jurnal ini, beberapa hasil penelitian terpilih diterbitkan dan dapat digunakan sebagai perkembangan dan acuan ilmu pengetahuan yang baru. Jurnal penelitian biasanya lebih berorientasi pada nilai akademik yang sangat bermanfaat bagi perkembangan ilmu pengetahuan.

\section{Laporan hasil penelitian}

Tidak semua hasil penelitian mempunyai kesempatan dipublikasikan dalam jurnal. Mereka terserak dalam rak perpustakaan atau di masingmasing dosen pembimbing. Para peneliti dapat mengakses dengan meminta izin dosen yang bersangkutan. Hasil penelitian yang ada dan substansi lainnya dalam hasil penelitian dapat diambil sebagai acuan kepustakaan. Perbedaannya adalah laporan tersebut belum. Acuan yang berasal dari jurnal maupun laporan hasil penelitian, kedua-duanya dapat digunakan untuk menyusun struktur studi literatur dan kerangka teoritis.

\section{Abstrak}

Tidak lain adalah ringkasan tentang laporan hasil penelitian. Sudah menjadi kesepakatan internasional bahwa abstrak perlu ada dalam setiap laporan hasil penelitian, baik yang sudah dipublikasikan maupun yang belum dipublikasikan. Bahkan untuk keperluan referensi suatu perguruan tinggi mengharuskan pembuatan abstrak dalam dua bahasa, yaitu bahasa Indonesia dan bahasa Inggris. Abstrak penelitian umumnya disusun secara narasi dengan menonjolkan tiga aspek penelitian yaitu tujuan penelitian, metodologi penelitian, dan hasil dari penelitian. Abstrak dibuat dengan narasi terbatas antara 150 sampai 300 kata tergantung kebijakan setiap universitas yang berkepentingan. Abstrak penelitian dicantumkan dalam awal laporan mempunyai tujuan agar para pembaca dan khususnya para peneliti dapat mengambil manfaat dari hasil penelitian yang dilaporkan dalam waktu yang relatif singkat.

Pada perpustakaan yang besar, abstrak diadministrasikan secara intensif agar dapat digunakan para peneliti maupun pembaca yang tertarik mencari informasi hasil penelitian. Karena bentuk abstrak yang ringkas, peneliti akan dapat secara cepat mengambil keputusan apakah informasi yang relevan, mereka dapat membaca pada laporan penelitian yang sebenarnya. 


\section{Narasumber}

Dalam mencari informasi, narasumber merupakan sumber informasi yang hidup. Karena mereka umumnya adalah manusia yang mempunyai kriteria tertentu dan mempunyai pengaruh yang positif dalam bidang ilmu tertentu. Yang termasuk narasumber diantaranya adalah sebagai berikut:

1) Para profesional, yaitu orang-orang yang mempunyai profesi atau terlibat secara langsung dengan kegiatan yang menjadi interest peneliti. Mereka ini mungkin para pekerja, pegawai, guru maupun pelaku yang mempunyai posisi baris depan dalam bidang tertentu.

2) Para ahli, yaitu orang-orang yang memilki keahlian dalam bidang tertentu, seperti dosen PT, para peneliti, manajer perusahaan, supervisor, dan lain-lain. Mereka mempunyai wewenang dalam memberikan data atau informasi yang berkaitan dengan permasalahan yang hendak diteliti oleh para peneliti.

Selain itu juga bisa didukung dari sumber data sekunder (secondary sources) seperti:

\section{Buku}

Sumber pustaka ilmian yang lain adalah buku yang secara resmi telah dipublikasi atau telah menjadi pegangan dalam mempelajari suatu bidang ilmu. Buku ini sangat penting karena sebagian bidang ilmu yang erat kaitannya dengan penelitian dan sebagian besar ada dalam bentuk buku yang ditulis oleh seorang pengarang ahli. Dalam kaitannya dengan buku sebagai sumber pustaka, para peneliti hendaknya mengacu pada wawasan yang lebih luas dalam hal penggunaan bahasa yang mencakup bahasa internasional termasuk bahasa Indonesia, Inggris, Prancis, Jerman, Jepang, dan China.

\section{Surat kabar dan majalah}

Media cetak merupakan sumber pustaka yang cukup baik dan mudah diperoleh dimasyarakat. Mengingat bahwa informasi dari surat kabar dan majalah merupakan informasi yang sifaknya populer, para peneliti dianjurkan untuk lebih dahulu mengevaluasi isi yang hendak diambil. Cara yang paling sederhana dan tetap efektif untuk diterapkan dalam mengevaluasi sumber informasi adalah dengan menanyakan seperti berikut ini: 
1) Apakah (what) isi dari surat kabar atau majalah relevan dengan permasalahan yang hendak dipecahkan dalam penelitian?

2) Siapakah (who) penulis atau narasumber yang telah menuliskan pokok bahasan mempunyai kriteria, sebagai profesional, akademis, atau sumber utama dalam suatu bidang tertentu?

3) Bagaimanakah (how) penulis mengutarakan pokok bahasan dalam surat kabar tersebut mengacu? Mereka mengacu dengan objektivitas keilmuan dan subjektivitas yang diutamakan.

4) Kapan (when) karya tulis tersebut dicetak atau diterbitkan? Untuk masalah Sosial Politik, Pendidikan, dan Ekonomi, waktu lima tahun mempunyai kemungkinan untuk berubah agar tetap relevan dengan permasalahan yang ada. Untuk bidang Matematika, Ilmu Pengetahuan Alam, dan Teknologi kecuali Teknologi Informasi, masa lima tahun mungkin masih mempunyai relevansi dengan masalah yang ada.

5) Mengapa (why) penulis menguraikan pendapatnya dalam surat kabar atau majalah? Adakah mereka mempumyai kepentingan ekonomis, politis, atau lebih ilmiah murni dalam acuan profesional dan akademik.

\section{Penelusuran dengan komputer (online database)}

Kemajuan teknologi membawa dampak yang sangat signifikan di bidang informasi. Dunia seolah sudah menjad semakin kecil, batas antarnegara dapat dilampaui dengan tidak melakukan intervensi. Dengan kemajuan teknologi informasi, kegiatan manusia semakin mengglobal, transaksi perdagangan dapat dilakukan dengan jaringan komunikasi, informasi mengalir dengan cepat. Apa yang terjadi dibelahan dunia yang satu dapat diketahui oleh belahan dunia yang lain melalui teknologi informasi.

Salah satu sumber informasi yang seolah tidak terbatas dapat diperoleh para peneliti melalui internet. Untuk menyesuaikan agar dapat mengambil manfaat yang maksimal, para peneliti hendaknya dapat mencari informasi yang terkait dengan permasalahan melalui internet. Para peneliti dapat membuka sendiri program internet yang dihubungkan dengan komputer milik sendiri di rumah. Mereka dapat menghubungi dan membuka jaringan internet tersebut melalui Telkom atau WiFi. 


\section{a. Isi studi kepustakaan}

Isi studi kepustakaan dapat berbentuk kajian teoritis yang pembahasannya difokuskan pada informasi sekitar permasalahan penelitian yang hendak dipecahkan melalui penelitian. Misalnya, jika sesorang peneliti hendak mengungkapkan tentang pengaruh prestasi belajar dilihat dari faktor-faktor: hubungan anak dengan orang tua, pekerjaan orang tua, dan status orang tua, maka peneliti dapat melakukan studi kepustakaan yang berhubungan dengan: teori sosiologi dan psikologi pendidikan anak serta hubungan sosial sekitar kegiatan anak dalam keluarga, peranan orang tua, dan jenis pekerjaan.

Materi dapat diambil dengan sekuensi yang sederhana menuju yang kompleks atau yang langsung berkaitan dengan masalah yang sedang menggejala saat sekarang. Kata-kata kunci seperti variabel, rangkaian teoritis dari setiap variabel, hasil penelitian yang dapat mendukung setiap variabel dan rangkaiannya. Pendapat pakar atau narasumber yang berkompetensi dibidangnya dan ulasan peneliti dalam usaha membangun kerangka teoritis dan mencapai hipotesis penelitian atau pertanyaan penelitian (research action).

\section{b. Jumlah referensi}

Tentang berapa jumlah acuan dalam kajian pustaka kadang ditanyakan oleh para peneliti muda atau para mahasiswa yang baru pertama kali mempunyai tugaa menyusun studi literatur dari sumber-sumber pustaka yang ada dan menghubungkan dengan permasalahan penelitian. Tidak ada batasan pasti tentang berapa jumlah buku yang harus digunakan sebagai acuan, tetapi ada petunjuk yang memberi arah bahwa semakin banyak buku dan sumber-sumber informasi mendukung kegiatan eksplorasi kajian pustaka, semakin baik dan menguntungkan bagi si peneliti.

Jika ternyata jumlah referensi yang ada sangat terbatas, peneliti dianjurkan untuk mencari sumber yang berhubungan erat misalnya tentang sejarah atau asal-usul tentang permasalahan yang hendak dipecahkan. Disamping itu peneliti juga diwajibkan melakukan eksplorasi lapangan, dengan menggunakan metode observasi dan wawancara kepada narasumber.

Satu kelengkapan yang perlu ada dalam eksplorasi pustaka adalah kemampuan menulis dan merangkai ide yang hendak dituangkan dalam kajian pustaka dengan inti permasalahan dan sumber-sumber yang betulbetul relevan. Pekerjaan menulis kajian pustaka itu dirasakan sulit bagi peneliti atau mahasiswa yang jarang menulis karya ilmiah. Akibatnya ada 
beberapa dari mereka yang terjebak dalam menyontek karya orang lain atau plagiator yang dilarang bagi para peneliti muda atau para mahasiswa karena dapat merugikan diri yang bersangkutan. Untuk mencegah hal seperti ini, perlu bagi para peneliti muda untuk latihan membuat karya ilmiah atau secara intensif bertanya pada pembimbing yang telah disediakan oleh lembaga pendidikan yang ada.

\section{c. Sitasi atau penyitiran}

Sitasi (citation) di dalam penulisan ilmiah sangat penting. Dalam penulisan ilmiah penulis memerlukan bahan pustaka (literatur review) untuk mendukung hasil tulisannya. Kegunaan bahan pustaka pendukung antara lain untuk menunjukkan adanya kebijakan di bidang kajiannya, menerangkan suatu teori, pengertian atau definisi, untuk memperlihatkan adanya temuan dari ilmuwan lain, untuk memperkuat temuannya, untuk memanfaatkan metode, sebagai pembanding dimana bahan pustaka yang direview memperlihatkan adanya perbedaan atau persamaan pendapat dengan ilmuwan lain, dan juga untuk memperkuat kesahihan penelitian yang dilakukan. Sitasi menunjukkan asal-usul atau sumber suatu kutipan, mengutip pernyataan, atau menyalin/mengulang pernyataan seseorang dan mencantumkannya di dalam suatu karya tulis yang dibuat, namun tetap mengindikasikan bahwa kutipan tersebut itu adalah pernyataan orang lain.

Suatu dokumen akan disitir oleh penulis apabila dokumen tersebut relevan dengan kegiatan penulisan karya ilmiah yang dilakukannya. Penyitiran dokemen ini dilakukan dengan maksud untuk membantu pengarang dalam mendapatkan informasi tambahan guna pemecahan masalah yang diteliti. Dokumen yang disitir sebaiknya berasal dari topik penelitian yang sama atau yang berhubungan dengan subjek penelitian. Pada dasarnya, semua kalimat, ide atau hasil karya yang bukan karya sendiri harus disebutkan sumbernya.

Salah satu pemilihan dokumen yang akan disitir adalah kesesuaian topik dengan penelitian, namun ada juga yang menyitir dari dokumen yang berbeda dengan topik penelitian misalnya untuk melihat analisa statistik maupun analisa data lainnya yang mungkin bisa digunakan pada penelitian yang sedang dilakukan karena dokumen tersebut memberikan informasi yang cukup dalam dan spesifik mengenai topik yang akan diteliti. Peneliti atau penulis akan menyitir suatu dokumen apabila dokumen tersebut memberikan informasi atau pengetahuan baru yang bisa bermanfaat bagi penelitiannya. 
Waktu dan tahun penerbitan dokumen yang akan direview juga menjadi bahan pertimbangan dalam menyitir suatu dokumen. Tahun penerbitan suatu dokumen merupakan hal yang penting karena dokumen yang terbitannya lebih terbaru atau mutakhir memuat informasi dan pengetahuan baru yang sedang berkembang pada saat itu. Dokumen yang sifatnya telah lama atau klasik juga masih disitir oleh banyak orang karena dokumen tersebut memberikan informasi yang masih relevan dengan keadaan saat ini, selain itu juga dokumen tersebut berisikan informasi awal dari perkembangan ilmu pengetahuan yang ada pada saat ini. Meskipun dokumen tersebut telah lama/usang namun apabila dokumen tersebut memuat informasi yang relevan dengan topik penelitian si peneliti atau penulis, maka dokumen tersebut akan disitir. Penyitiran dari dokumen lama bisa diambil dan dibandingkan serta dimodifikasi dengan ilmu pengetahuan yang berkembang pada saat ini. Kemudahan dalam mendapatkan dokumen yang akan direview juga menjadi faktor penting dalam menentukan sebuah dokumen menjadi sitiran. Hal ini bisa dilihat dari kemudahan untuk mendapatkan dokumen secara kontinue maupun kemudahan mengakses bila dilakukan melalui internet. Sebagai contoh, makalah atau jurnal ilmiah bisa dijadikan sebagai sumber sitiran karena makalah atau jurnal ilmiah tersebut frekuensi terbitnya teratur sehingga bisa dijadikan sebagai acuan dalam menyitir.

Ada beberapa referensi dalam mengacu sumber informasi, antara lain adalah cara mengacu yang ditentukan oleh IEEE (Institute of Electrical and Electronics Engineers) Citation Style dan Chicago Citation Style. Pada cara pengacuan menurut IEEE, setiap referensi diberi nomor berdasarkan urutan kemunculannya pada dokumen. Ketika mengacu suatu referensi dalam tulisan, digunakan nomor referensi yang diapit oleh kurung siku.

Contoh:

a. Pengacuan dalam teks

Pembelajaran bagi siswa di Sekolah Dasar (SD) pada usia 7 - 11 tahun menurut Piaget [1] berada pada fase operasional konkret. Berdasarkan fase ini, pembelajaran matematika juga hendaknya diawali dengan sesuatu yang konkret dan nyata, dekat dengan kehidupan, pengetahuan dan pengalaman siswa. Freudenthal [2] menyatakan bahwa matematika adalah aktivitas manusia dan harus dikaitkan dengan realitas. Freudenthal memandang matematika bukan sebagai suatu produk jadi yang kita berikan kepada siswa, melainkan suatu proses yang dikonstruksi oleh 
siswa. Dalam pembelajaran matematika model yang sesuai dengan filosofi di atas adalah pendekatan Pembelajaran Matematika Realistik (PMR). Gravemeijer [3] pendekatan PMR mempunyai lima karateristik yaitu: penggunaan konteks, menggunakan model untuk mengkonstruksi konsep, pembuatan pondasi ke tahap matematika formal, terdapat interaksi, terdapat keterkaitan antara unit-unit matematika. Dalam PMR, matematika tidak dipandang sebagai produk jadi yang langsung disampaikan dalam bentuk rumusrumus, melainkan melalui proses penemuan konsep dan pemahaman materi.

b. Pengacuan dalam daftar pustaka

Akker, J. van den, Gravemeijer, K., McKenney, S., \& Nieveen, N. (2006). INTRODUCING EDUCATIONAL DESIGN RESEARCH. London: Routledge Taylor and Francis Group.

Arikunto, S. (2010). Prosedur Penelitian: Suatu Pendekatan Praktek. Jakarta: Rineka Cipta.

Bennett, N., Borg, W. R., \& Gall, M. D. (1984). Educational Research: An Introduction. In British Journal of Educational Studies (Seventh Ed, Vol. 32, Issue 3). Boston: Longman. https://doi.org/10.2307/3121583

Branch, R. M. (2009). Instructional design: The ADDIE approach. Springer Science \& Business Media.

DiSessa, A. A., \& Cobb, P. (2014). Ontological Innovation and the Role of Theory in Design Experiments. THE JOURNAL OF THE LEARNING SCIENC, 13(2), 77-104.

Farman, F., \& Yusryanto, Y. (2018). PENGEMBANGAN DESAIN PEMBELAJARAN BERBASIS PROBLEM POSING DALAM UPAYA MENINGKATKAN KEMAMPUAN PENALARAN KONSEP LINGKARAN PADA SISWA SMP KELAS VIII. Jurnal Karya Pendidikan Matematika, 5(2), 20. https://doi.org/10.26714/jkpm.5.2.2018.20-27

Fauzan, A. (2002). APPLYING REALISTIC MATHEMATICS EDUCATION (RME) IN TEACHING GEOMETRY IN INDONESIAN PRIMARY SCHOOLS. Enschede: University of Twente.

Hasnunidah, N. (2017). Metodologi Penelitian Pendidikan. Media Akademi.

Knipples, \& Josephina, M.-C. P. (2002). Coping with the abstract and complex nature of genetics in biology education. Utrecht, The Netherlands: University of Utrecht.

Lutvaidah, U. (2016). Pengaruh Metode dan Pendekatan Pembelajaran 
terhadap Penguasaan Konsep Matematika. Formatif: Jurnal Ilmiah Pendidikan MIPA. https://doi.org/10.30998/formatif.v5i3.653

Mangelep, N. O. (2011). KONTEKS MEMBAGI ROTI DALAM MEMPELAJARI LUAS SEGITIGA. IMPoME 2011 Sriwijaya UNiversity.

Margono, S. (2004). Metodologi Penelitian Pendidikan. Jakarta : Rineka Cipta.

Muhammad, A. (1982). Penelitian Pendidikan Prosedur dan Strategi. Bandung Angkasa.

Mulyatiningsih, E. (2011). Riset Terapan Bidang Pendidikan dan Teknik (Nuryanto Apri (ed.); 1st ed.). Yogyakarta: UNY Press. http://staffnew.uny.ac.id/upload/132296045/lainlain/buku-risetterapan-apri.pdf

Plomp, T., \& Nieveen, N. (2013). SLO: The Seminar on an Introduction to Educational Design Research. In an Introduction to Educational Design Research. The Netherlands: SLO.

Purnomo, E. A., Dalyono, B., \& Handayani, S. (2018). PENGEMBANGAN MEDIA PEMBELAJARAN BERBASIS ANDROID PADA MATA KULIAH STATISTIKA PENDIDIKAN. Jurnal Karya Pendidikan Matematika, 5(2), 117-120. https://doi.org/https://doi.org/10.26714/jkpm.5.2.2018.117120

Putra, Y. Y., \& Vebrian, R. (2019). DESAIN PEMBELAJARAN PMRI MATERI OPERASI HITUNG BILANGANMENGGUNAKAN KONTEKS KERETAK GETAS. MATHEMA JOURNAL, 1(1), 1-14.

Putrawangsa, S. (2018). DESAIN PEMBELAJARAN Design Research sebagai Pendekatan Desain Pembelajaran (1st ed.). CV. Reka Karya Amerta (Rekarta).

PUTRAWANGSA, S., LUKITO, A., MAMIN, S., \& WIJERS, M. (2014). EDUCATIONAL DESIGN RESEARCH: DEVELOPING STUDENTS' UNDERSTANDING OF THE MULTIPLICATION STRATEGY IN AREA MEASUREMEN. Prosiding Konferensi Nasional Matematika (KNM) XVII, 633-648.

Simon, M. A. (1995). RECONSTRUCTING MATHEMATICS PEDAGOGY FROM A CONSTRUCTIVIST PERSPECTIVE. Journal for Re.;Earcl! In Mathematits Educ: tion, 26(2), 114-145.

Sohilait, E. (2018). Pengembangan Perangkat Pembelajaran Matematika pada Materi Himpunan Melalui pendekatan Pendidikan Matematika Realistik.

Sohilait, E. (2019). Desain Pembelajaran Berbasis Pendekatan Pendidikan 
Matematika Realistik Dengan Menggunakan Masalah Kontekstual. Prosiding Seminar Nasional Pendidikan Matematika.

Sugiyono. (2009). Metode Penelitian Pendidikan Pendekatan Kuantitatif. Bandung : Alfabeta.

Sugiyono, P. D. (2017). Metode Penelitian Bisnis: Pendekatan Kuantitatif, Kualitatif, Kombinasi, dan R\&D. (25th ed.). Alfabeta Bandung.

Sujarweni, V. W. (2014). Metode Penelitian: Lengkap, Praktis, dan Mudah Dipahami. Pustaka Baru Press.

Sukardi. (2003). Metodologi Penelitian Pendidikan (1st ed.). Jakarta: Bumi Aksara.

Sukmadinata, N. S. (2012). Metode Penelitian Pendidikan. PT. Remaja Rosdakarya.

Van den Akker, J. (2006). Educational Design Research. In Educational Design Research. Netherlands: Roudledge. https://doi.org/10.4324/9780203088364

Wahyuni, Y. (2017). IDENTIFIKASI GAYA BELAJAR (VISUAL, AUDITORIAL, KINESTETIK) MAHASISWA PENDIDIKAN MATEMATIKA UNIVERSITAS BUNG HATTA. Jurnal Penelitian Dan Pembelajaran Matematika. https://doi.org/10.30870/jppm.v10i2.2037

Warsito, W., Nuraini, Y., \& Sukirwan, S. (2019). Desain Pembelajaran Pecahan melalui Pendekatan Realistik di Kelas V. Mosharafa: Jurnal Pendidikan Matematika. https://doi.org/10.31980/mosharafa.v8i1.381 Wijaya, A. (2008). Design Research in Mathematics Education:Indonesian Traditional Games as Means to Support Second Graders' Learning of Linear Measurement. Utrecht: Utrecht University.

Referensi [1] adalah sebuah buku, referensi [2] dan [3] adalah artikel pada jurnal. 
Berbeda dengan model acuan IEEE, pada model acuan Chicago, referensi-referensi diurutkan berdasarkan abjad pada Daftar Pustaka.

Pengacuan dalam teks

(Ningsih, 2014)

\section{Daftar pustaka}

Trianingsih, R. (2016). Pengantar Praktik

Mendidik Anak Usia Sekolah Dasar. Al Ibtida:

Jurnal Pendidikan Guru MI, 3(2), 197.

https://doi.org/10.24235/al.ibtida.snj.v3i2.8

$\underline{80}$

(Zaini \& Marsigit, Zaini, A., \& Marsigit, M. (2014). PERBANDINGAN 2014)

KEEFEKTIFAN PEMBELAJARAN

MATEMATIKA DENGAN PENDEKATAN

MATEMATIKA REALISTIK DAN

KONVENSIONAL DITINJAU DARI

KEMAMPUAN PENALARAN DAN

KOMUNIKASI MATEMATIK SISWA. Jurnal

Riset Pendidikan Matematika, 1(2), 152.

https://doi.org/10.21831/jrpm.v1i2.2672

Selain dua metode di atas, metode sitasi yang digunakan dapat juga berasal dari bahan pustaka elektronik seperti:

APA Style $\quad$ : Psikologi, Pendidikan, dan ilmu-ilmu Sosial

MLA Style : Literatur, Seni, dan Humanities

AMA Style : Keperawatan, Kesehatan, dan Ilmu Biologi

Dalam melakukan penyitiran seorang peneliti atau penulis ilmiah wajib mencantumkan nama pengarang yang pernyataannya dikutip atau disitir di dalam artikel/makalah/laporan hasil penelitian. Kewajiban tersebut untuk memperlihatkan bahwa sesungguhnya peneliti tersebut telah menelaah terlebih dahulu, penelitian setopik yang pernah dilakukan oleh orang lain, dan secara jujur mencantumkan bahan pustaka yang dikutipnya. Cara mencantumkan nama pengarang buku, artikel, atau pun sumber informasi lain yang tercetak sudah ada aturannya tersendiri, yang tentunya sudah biasa dilakukan oleh peneliti. Menulis daftar pustaka (bibliografi) bertujuan untuk menguraikan dengan jelas semua sumber rujukan dan bacaan yang telah dicantumkan di dalam tulisan, baik berupa buku, jurnal dan majalah, tesis dan disertasi, dan lain sebagainya. Daftar pustaka ini dapat membantu pembaca untuk mengetahui sumber-sumber yang digunakan dalam penulisan ilmiah. Ada beberapa hal yang perlu diperhatikan dalam 
penyusunan daftar pustaka, yaitu daftar pustaka tidak diberi nomor, urutan nama penulis mengikut urutan huruf, gelar penulis tidak dimasukkan, bibliografi diletakkan pada bagian terakhir tulisan, nama pengarang ditulis penuh dalam susunan asal.

Urutan unsur-unsur yang ditulis dalam bibliografi ialah: Nama penulis, Tahun penerbitan, Judul - digaris atau dicetak miring, Tempat penerbitan, dan Nama penerbit. Berikut ini diberikan beberapa contoh penulisan daftar pustaka (bibliografi) beradasarkan standar APA, MLA dan AMA.

Berikut ini contoh rumusan sitasi untuk APA Style (American Psychological Association):

[1]. Journal or Magazine Article (use for journals that start each issue with page one)

Wilcox, R. V. (1991). Shifting roles and synthetic women in Star trek:

The next generation. Studies in Popular Culture, 13(2), 53-65.

[2]. Journal or Magazine Article (use for journals where the page numbering continues

from issue to issue)

Dubeck, L. (1990). Science fiction aids science teaching. Physics

Teacher, 28, 316-

318.

[3]. Newspaper Article

Di Rado, A. (1995, March 15). Trekking through college: Classes explore modern society using the world of Star trek. Los Angeles Times, p. A3.

[4]. Article from an Internet Database (for more details, see the American Psychological Association's official site)

Mershon, D. H. (1998, November-December). Star trek on the brain: Alien minds, human minds. American Scientist, 86, 585. Retrieved July 29, 1999, from Expanded Academic ASAP database.

[5]. Book

Okuda, M., \& Okuda, D. (1993). Star trek chronology: The history of the future.

New York: Pocket Books.

[6]. Book Article or Chapter

James, N. E. (1988). Two sides of paradise: The Eden myth according to Kirk and Spock.

In D. Palumbo (Ed.), Spectrum of the fantastic (pp. 219-223). Westport, CT: Greenwood. 


\section{[7]. Encyclopedia Article}

Sturgeon, T. (1995). Science fiction. In The encyclopedia Americana (Vol. 24, pp. 390-392). Danbury, CT: Grolier.

[8]. ERIC Document

Fuss-Reineck, M. (1993). Sibling communication in Star trek: The next generation: Conflicts between brothers. Miami, FL: Annual Meeting of the Speech Communication Association. (ERIC Document Reproduction Service No. ED 364932)

[9]. Web site (for more details, see the American Psychological Association's official site)

Lynch, T. (1996). DS9 trials and tribble-ations review. Retrieved October 8, 1997, from Psi Phi: Bradley's Science Fiction Club Web site:

http://www.bradley.edu/campusorg/psiphi/DS9/ep/503r.html

Berikut ini contoh rumusan sitasi untuk MLA (Modern Language Association) Style:

[1]. Book

Okuda, Michael, and Denise Okuda. Star Trek Chronology: The

History of the Future. New York: Pocket, 1993.

[2]. Journal Article

Wilcox, Rhonda V. "Shifting Roles and Synthetic Women in Star Trek: The Next Generation." Studies in Popular Culture 13.2 (1991): 53-65.

[3]. Newspaper or Magazine Article

Di Rado, Alicia. "Trekking through College: Classes Explore Modern Society Using the World of Star Trek." Los Angeles Times 15 Mar. 1995: A3.

[4]. Book Article or Chapter

James, Nancy E. "Two Sides of Paradise: The Eden Myth According to Kirk and Spock." Spectrum of the Fantastic. Ed. Donald Palumbo. Westport: Greenwood, 1988. 219-223.

[5]. Encyclopedia Article (well known reference books)

Sturgeon, Theodore. "Science Fiction." The Encyclopedia Americana. International ed. 1995.

[6]. Encyclopedia Article (less familiar reference books)

Horn, Maurice. "Flash Gordon." The World Encyclopedia of Comics.

Ed. Maurice Horn. 2 vols. New York: Chelsea, 1976. 
[7]. Gale Reference Book (and other books featuring reprinted articles) Shayon, Robert Lewis. "The Interplanetary Spock." Saturday Review 17 June 1967: 46. Rpt. in Contemporary Literary Criticism. Ed. Sharon R. Gunton. Vol. 17. Detroit: Gale Research, 1981. 403.

[8]. ERIC Document

Fuss-Reineck, Marilyn. Sibling Communication in Star Trek: The Next Generation: Conflicts between Brothers. Miami: Speech

Communication Assn., 1993. ERIC Document Reproduction Service ED364932.

\section{[9]. Website}

Lynch, Tim. "DSN Trials and Tribble-ations Review." Psi Phi: Bradley's Science Fiction Club. 1996. Bradle University. 8 Oct. 1997 <http://www.bradley.edu/campusorg/psiphi/DS9/ep/503r.html>.

[10]. Newspaper or Magazine Article on the Internet

Andreadis, Athena. "The Enterprise Finds Twin Earths Everywhere It Goes, But Future Colonizers of Distant Planets Won't Be So Lucky." Astronomy Jan. 1999: 64-. Academic Universe. Lexis-Nexis. B. Davis Schwartz Memorial Lib., Brookville, NY. 7 Feb. 1999 $<$ http://web.lexis-nexis.com/universe $>$.

[11]. Literature Resource Center

Shayon, Robert Lewis. "The Interplanetary Spock." Saturday Review 17 June 1967: 46. Rpt. in Contemporary Literary Criticism.

Ed. Sharon R. Gunton. Vol. 17. Detroit: Gale Research, 1981. 403.

Literature Resource Center. Gale Group. B. Davis Schwartz Memorial Lib., Brookville, NY. 16 Oct. 2001

$<$ http://infotrac.galegroup.com/menu $>$.

Berikut ini contoh rumusan sitasi untuk AMA (American Medical Association) Style:

[1]. Book

Okuda M, Okuda D. Star Trek Chronology: The History of the Future. New York: Pocket Books; 1993.

[2]. Journal or Magazine Article (with volume numbers)

Wilcox RV. Shifting roles and synthetic women in Star trek: the next generation.

Stud Pop Culture. 1991;13:53-65. 
[3]. Newspaper, Magazine or Journal Article (without volume numbers)

Di Rado A. Trekking through college: classes explore modern society using the world of Star trek. Los Angeles Times. March 15, 1995:A3.

\section{[4]. Encyclopedia Article}

Sturgeon T. Science fiction. In: Lorimer LT, editorial director; Cummings $\mathrm{C}$, ed- in-chief; Leish $\mathrm{KW}$, managing ed. The Encyclopedia Americana. Vol 24. International ed. Danbury, Conn: Grolier Incorporated; 1995:390-392.

\section{[5]. Book Article or Chapter}

James NE. Two sides of paradise: the Eden myth according to Kirk and Spock. In: Palumbo D, ed. Spectrum of the Fantastic. Westport, Conn: Greenwood; 1988:219-223.

\section{[6]. ERIC Document}

Fuss-Reineck M. Sibling Communication in Star Trek: The Next Generation: Conflicts Between Brothers. Miami, Fla: Annual Meeting of the Speech Communication Association; 1993. ERIC Document Reproduction Service ED364932.

\section{[7]. Website}

Lynch T. DSN trials and tribble-ations review. Psi Phi: Bradley's Science Fiction Club Web site. 1996. Available at: http://www.bradley.edu/campusorg/psiphi/ DS9/ep/503r.htm. Accessed October 8, 1997.

\section{[8]. Journal Article on the Internet}

McCoy LH. Respiratory changes in Vulcans during pon farr. J Extr Med [serial online]. 1999;47:237-247. Available at: http://infotrac.galegroup.com/itweb/ nysl li liu. Accessed April 7,1999.

Berikut ini juga disajikan beberapa contoh penulisan sitiran dalam daftar pustaka:

\section{Sitiran Buku}

Nama pengarang. Judul buku. $2^{\text {nd }}$ ed. 2 vols. Informasi mengenai penerbitan. Marcuse, Sibyl. A Survey of Musical Instruments. New York: Harper, 1975.

- - -. Judul buku. Informasi mengenai penerbitan.

- - -, ed. Judul buku. Informasi mengenai penerbitan 
- - -, trans. Judul buku. Informasi mengenai penerbitan.

Jika nama pengarang lebih dari satu, maka dapat ditulis sesuai dengan format berikut ini:

Contoh:

Jakobson, Roman, dan Linda R. Waugh. Judul buku. Informasi mengenai penerbitan.

Namun jika pengarangnya lebih dari 3 orang, maka dalam daftar pustaka dapat ditulis dengan format berikut ini.

Contoh:

Gilman, Sender, et al. Judul buku. Informasi mengenai penerbitan

\section{Publikasi Pemerintah}

Contoh:

United Nations. Consequences of Rapid Population Growth in

DevelopingCountries. New York: Taylor, 1991.

\section{Publikasi Prosiding atau Konfrensi}

Contoh:

Freed, Barbara F., ed. Foreign Language Acquisition Research and the Classroom. Proceeding of Consortium for Language Teaching and Learning Conference, Oct. 1989, U of Pensylvania. Lexington: Heath, 1991.

\section{Disertasi}

Nama pengarang. Judul buku. Disertasi. Informasi mengenai universitas

\section{Artikel dari jurnal, surat kabar, majalah}

Nama pengarang. "Judul artikel". Informasi penerbitan

Contoh:

Barthelme, Frederick. "Architecture." Kansas Quarterly 13. 3-4 (1981): 77 80. Feder, Barnaby J. "For Job Seekers, a Toll-Free Gift of Expert Advice." New York Times 30 December 1993.

Contoh:

Frank, Michael. "The Wild, Wild West." Archetectural Digest June 1993: 180- 190.

\section{Sumber online}

Contoh: George D. Gopen dan Judith A. Swan. The Science of Scientic Writing". http://www.research.att.com/ andreas/sci.html

\section{Sitiran dari CD-ROM}

Materi dari jurnal yang diakses melalui CD-ROM Contoh: 
Angier, Natalie. "Chemist Learn Why Vegetables Are Good for You." New York Times 13 April1993. New York Times Ondisc. CD-ROM. UMI-Proquest. October 1993.

"Time Warner, Inc.: Sales Summary, 1988 - 1992." Disclosure/Wordscope. CD- ROM. October 1993.

\section{d. Mengorganisasi substansi kajian pustaka}

Kerangka berpikir yang baik akan menjelaskan secara teoritis pertautan antar variabel yang akan diteliti. Jadi secara teoritis perlu dijelaskan hubungan antar variabel independen dan dependen. Bila dalam penelitian ada variabel moderator dan intervening, maka perlu dijelaskan mengapa variabel itu juga ikut dilibatkan dalam penelitian. Oleh karena itu pada setiap penyusunan paradigma penelitian harus didasarkan pada kerangka berpikir.

Kerangka berpikir dalam suatu penelitian perlu dikemukakan apabila dalam penelitian itu berkaitan dua variabel atau lebih. Apabila penelitian hanya membahas sebuah variabel atau lebih seara mandiri, maka yang dilakukan peneliti disamping mengemukakan deskripsi teoritis untuk masing-masing variabel, juga argumentasi terhadap variasi bersaran variabel yang diteliti (Sapto Haryoko, 1999).

Penelitian yang berkaitan dengan dua variabel atau lebih biasanya dirumuskan hipotesis yang berbentuk komparasi atau hubungan. Langkah-langkah dalam menyusun kerangka pemikiran yang selanjutnya membuahkan hipotesis ditunjukkan pada gambar 5.1.

Seorang peneliti harus menguasai teori-teori ilmiah sebagai dasar bagi argumentasi dalam menyusun kerangka pemikiran yang membuahkan hipotesis. Kerangka pemikiran ini merupakan penjelasan sementara terhadap gejala-gejala yang menjadi obyek permasalahan. (Suriasumantri, 1986). Kriteria utama agar suatu kerangka pemikiran meyakinkan adalah alur-alur pikiran yang logus dalam membangun suatu kerangka berpikir yang membuahkan kesimpulan berupa hipotesis. Jadi kerangka berpikir merupakan sintesa tentang hubungan antar variabel yang disusun dari berbagai teori yangt telah dideskripsikan. Berdasarkan teoriteori yang telah dideskripsikan tersebut selanjutnya dianalisis secara kritis dan sistematis sehingga menghasilkan tentang sintesa tentang hubungan antar variabel yang diteliti. Sintesa tentang 
hubungan variabel tersebut, selanjutnya digunakan untuk merumuskan hipotesis.

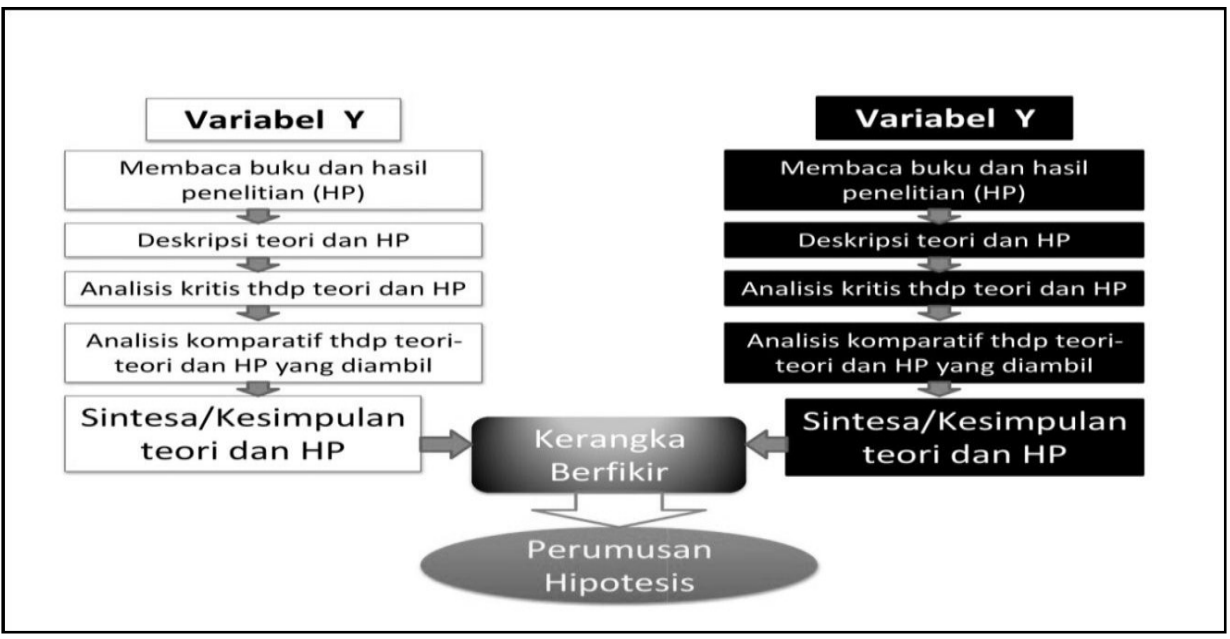

Gambar 5.1. Proses penyusunan Kerangka Berpikir untuk merumuskan Hipotesis

Berdasarkan gambar di atas dapat diberikan penjelasan sebagai berikut:

1) Menetapkan variabel yang diteliti

Berapa jumlah variabel yang diteliti dan apakah nama setiap variabel merupakan titik tolak untuk menentukan teori yang akan digunakan.

2) Membaca Buku dan Hasil Penelitian (HP)

Setelah variabel ditentukan, maka langkah berikutnya adalah membaca buku-buku dan hasil penelitian yang relevan. Buku-buku yang dibaca dapat bebentuk buku teks, ensiklopedia dan kamus. Hasil penelitian yang dapat dibaca adalah laporan penelitian, jurnal ilmiah, Skripsi, Tesis dan Disertasi.

\section{3) Deskripsi Teori dan Hasil Penelitian (HP)}

Dari buku hasil penelitian yang dibaca akan dikemukakan teori-teori yang berkaitan dengan variabel yang diteliti. Seperti telah dikemukakan, deskripsi teori berisi tentang, definisi terhadap masingmasing variabel yang diteliti, uraian rinci tentang ruang lingkup setiap variabel, dan kedudukan antara variabel satu dengan yang lain dalam konteks penelitian itu. 


\section{4) Analisis Kritis terhadap Teori dan Hasil Penelitian}

Pada tahap ini peneliti akan melakukan analisis secara kritis terhadap teori-teori dan hasil penelitian yang telah dikemukakan. Dalam analisis ini peneliti akan mengkaji apakah teori-teori dan hasil penelitian yang telah ditetapkan itu betul-betul sesuai dengan obyek penelitian atau tidak, karena sering terjadi teori-teori yang berasal dari luar tidak sesuai untuk penelitian di dalam negeri.

5) Anasilis Komparatif terhadap Teori dan Hasil Penelitian

Analisis komparatif dilakukan dengan cara membandingkan antara teori satu dengan teori yang lain. Melalui analisis komparatif ini peneliti dapat memadukan antara teori satu dengan teori yang lain, atau mereduksi bila dipandang terlalu luas.

6) Sintesa Kesimpulan

Melalui analisis kritis dan komparatif terhadap teori-teori dan hasil penelitian yang relevan dengan semua variabel yang diteliti, selanjutnya peneliti dapat melakukan sintesa atau kesimpulan sementara. Perpaduan sintesa antara variabel satu dengan variabel yang lain akan menghasilkan kerangka berpikir yang selanjutnya dapat digunakan untuk merumuskan hipotesis.

7) Kerangka Berpikir

Setelah sintesa atau kesimpulan sementara dapat dirumuskan maka selanjutnya disusun kerangka berpikir. Kerangka berpikir yang dihasilkan dapat berupa kerangka berpikir asosiatif/hubungan maupun komparatif/perbandingan. Kerangka berpikir asosiatif dapat menggunakan kalimat: jika begini maka akan begitu: Jika guru kompeten, maka hasil belajar akan tinggi. Jika kepemimpinan kepala sekolah baik, maka iklim kerja sekolah akan baik. Jika kebijakan pendidikan dilaksanakan secara baik dan konsisten, maka kualitas SDM di indonesia akan meningkat pada graduasi yang tinggi.

8) Hipotesis

Berdasarkan kerangka berpikir tersebut selanjutnya disusun hipotesis. Bila kerangka berpikir berbunyi "jika guru kompeten, maka hasil belajar akan tinggi", maka hipotesisinya berbunyi "ada hubungan yang positif dan signifikan antara kompetensi guru dengan hasil belajar". Bila kerangka berpikir berbunyi "Karena lembaga Pendidikan A menggunakan teknologi pembelajaran yang lebih tinggi, maka kualitas hasil belajar akan lebih tinggi bila dibandingkan dengan lembaga Pendidikan B yang teknologi pembelajarannya rendah", maka hipotesis 
berbunyi "Terdapat perbedaan kualitas hasil belajar yang signifikan antara lembaga Pendidikan A dan B", atau hasil belajar lembaga Pendidikan A lebih tinggi dibandingkan dengan lembaga Pendidikan B".

\section{HIPOTESIS}

Perumusan hipotesis penelitian merupakan langkah ketiga dalam penelitian, setelah peneliti mengemukakan landasan teori dan kerangka berpikir. Tetapi perlu diketahui bahwa tidak setiap penelitian harus merumuskan hipotesis. Penelitian yang bersifat eksploratif dan deskriftif sering tidak perlu merumuskan hipotesis.

Hipotesis merupakan jawaban sementara dalam rumusan masalah penelitian, dimana rumusan penelitian telah dinyatakan dalam pernyataan. Dikatakan sementara karena jawaban yang diberikan baru didasarkan pada teori yang relevan, belum didasarkan pada fakta-fakta empiris yang diperoleh melalui pengumpulan data. Jadi hipotesis juga dapat dinyatakan sebagai jawaban teoritis terhadap rumusan masalah penelitian, belum jawaban yang empirik dengan data.

Penelitian yang merumuskan hipotesis adalah penelitian yang menggunakan pendekatan kuantitatif. Pada penelitian kuantitatif tidak dirumuskan hipotesis, tetapi diharapkan dapat ditemukan hipotesis. Selanjutnya hipotesis akan diuji oleh peneliti dengan menggunakan pendekatan kuantitatif.

Dalam ini perlu dibedakan pengertian hipotesis penelitian dan hipotesis statistik. Pengertian hipotesis penelitian seperti telah dikemukakan di atas. Selanjutnya hipotesis statistik itu ada, bila penelitian bekerja dengan sampel. Jika penelitian tidak menggunakan sampel, maka tidak ada hipotesis statistik.

Dalam suatu penelitian, dapat terjadi ada hipotesis penelitian, tetapi tidak ada hipotesis statistik. Penelitian yang dilakukan pada seluruh populasi mungkin akan terdapat hipotesis penelitian tetapi tidak akan ada hipotesis statistik. Ingat bahwa hipotesis itu berupa jawaban sementara terhadap rumusan masalah dan hipotesis yang akan diuji ini dinamakan hipotesis kerja. Sebagai lawannya adalah hipotesis nol (nihil). Hipotesis kerja disusun berdasarkan atas teori yang dipandang handal, sedangkan hipotesis nol dirumuskan karena teori yang digunakan masih diragukan kehandalannya. Untuk lebih mudah membedakan antara hipotesis penelitian dan hipotesis statistik, maka dapat dipahami melalui gambar 5.2. dan 5.3 


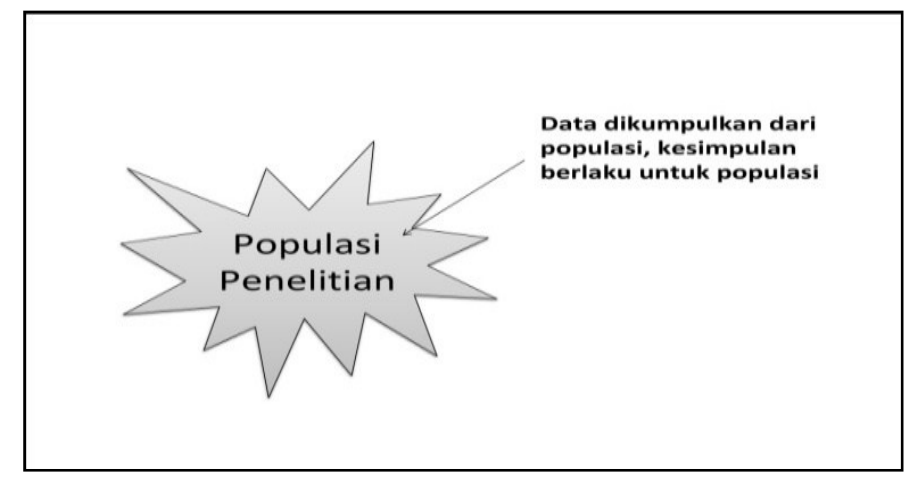

Gambar 5.2. Penelitian Populasi,tidak ada Hipotesis Statistik (Sugiyono, 2017)

Contoh hipotesis penelitiannya:

1. Kemampuan bahasa asing siswa-siswa SMP itu rendah (hipotesis deskriptif untuk populasi, hipotesis ini sering tidak dirumuskan dalam penelitian sosial).

2. Tidak terdapat perbedaan hasil belajar antara Sekolah Negeri dan Swasta. (hipotesis komparatif, untuk populasi).

3. Ada hubungan positif antara penghasilan orang tua dengan ketersediaan fasilitas belajar anak. (hipotesis asosiatif, untuk populasi).

Pada gambar 5.2 di atas yang diteliti adalah populasi, sehingga hipotesis statistiknya tidak ada. Yang ada hanya hipotesis penelitian. Dalam pembuktiannya tidak ada istilah "signifikansi" (taraf kesalahan atau taraf kepercayaan).

Selanjutnya perhatikan pula gambar 5.3 terdapat hipotesis penelitian dan hipotesis statistik. Hipotesis statistik diperlukan untuk menguji apakah hipotesis penelitian yang hanya diuji dengan data sampel itu dapat diberlakukan untuk populasi atau tidak. Dalam pembuktian ini akan muncul istilah signifikansi, atau taraf kesalahan atau kepercayaan dari pengujian. Signifikansi artinya hipotesis penelitian yang telah terbukti pada sampel itu (baik deskriptif, komparatif, maupun asosiatif) dapat diberlakukan ke populasi.

Contoh hipotesis penelitian yang mengandung hipotesis statistik: 
1. Ada perbedaan yang signifikan antara prestasi belajar dalam sampel dengan populasi. Prestasi belajar anak paling tinggi dengan nilai 6.5 (hipotesis deskriptif, sering tidak dirumuskan dalam penelitian).

2. Terdapat perbedaan yang signifikan antara semangat belajar anak dari keluarga petani dan nelayan (hipotesis komparatif, petani dan nelayan adalah sampel).

3. Ada hubungan yang positif dan signifikan antara kerajinan belajar dengan prestasi belajar anak pada sekolah A. (hipotesis asosiatif/hubungan; data dari sekolah A diambil dengan sampel). Ada hubungan positif artinya, bila anak rajin belajar, maka prestasi belajar akan tinggi.

Terdapat dua macam hipotesis penelitian yaitu hipotesis kerja dan hipotesis nol. Hipotesis kerja dinyatakan dalam kalimat positif dan hipotesis nol dinyatakan dalam kalimat negatif.

Contoh hipotesis kerja $\left(\mathrm{H}_{\mathrm{a}}\right)$ :

1) Jika orang banyak makan, maka berat badannya akan naik.

2) Ada perbedaan antara penduduk kota dan penduduk desa dalam cara berpakaian.

3) Ada pengaruh makanan terhadap berat badan.

Contoh hipotesis nol $\left(\mathrm{H}_{\mathrm{o}}\right)$ :

1) Tidak ada perbedaan antara mahasiswa tingkat I dan mahasiswa tingkat II dalam disiplin kuliah.

2) Tidak ada pengaruh jarak dari rumah ke sekolah terhadap kerajinan mengikuti kuliah.

Dalam statistik juga terdapat dua macam hipotesis kerja dan hipotesis alternatif (hipotesis alternatif tidak sama dengan hipotesis kerja). Dalam kegiatan penelitian, yang diuji terlebih dulu adalah hipotesis penelitian terutama pada hipotesis kerjanya. Bila penelitian akan membuktikan apakah hasil pengujian hipotesis itu signifikansi atau tidak, maka diperlukan hipotesis statistik. Teknik statistik yang digunakan untuk menguji hipotesis ini adalah statistik inferensial. Statistik yang bekerja dengan data populasi adalah statistik deskriptif. 


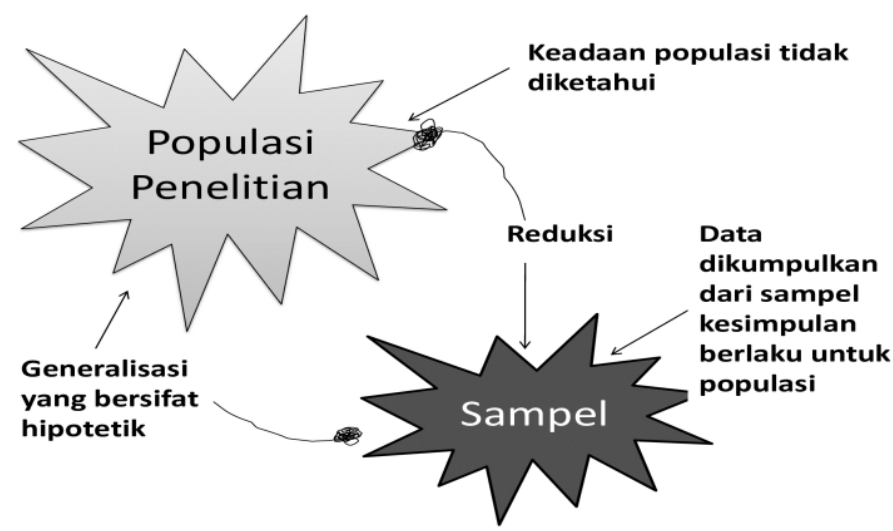

Gambar 5.3. Penelitian bekerja dengan Data Sampel, ada Hipotesis Statistik (Sugiyono, 2017)

Dalam hipotesis statistik, yang diuji adalah hipotesis nol, hipotesis yang menyatakan tidak ada perbedaan antara data sampel dan data populasi. Yang diuji hipotesis nol karena peneliti tidak berharap ada perbedaan antara sampel dan populasi atau statistik dan parameter. Parameter adalah ukuran-ukuran yang berkaitan dengan populasi, dan statistik disini diartikan sebagai ukuranukuran yang berkaitan dengan sampel.

a) Bentuk-bentuk hipotesis

Bentuk-bentuk hipotesis penelitian sangat terkait dengan rumusan masalah penelitian. Bila dilihat dari tingkat eksplanasinya, maka bentuk rumusan masalah penelitian ada tiga yaitu: rumusan masalah deskriptif (variabel mandiri), komparatif (perbandingan), dan asosiatif (hubungan). Oleh karena itu, maka bentuk hipotesis penelitian juga ada tiga yaitu hipotesis deskriptif, komparatif, dan asosiatif.

\section{Hipotesis deskriptif}

Hipotesis deskriptif merupakan jawaban sementara terhadap masalah deskriptif, yaitu yang berkaitan dengan variabel mandiri.

Contoh:

1) Rumusan masalah deskriptif

a) Berapa lama daya tahan berdiri karyawan toko lulusan SMK?

b) Seberapa semangat belajar mahasiswa Perguruan Tinggi negeri?

2) Hipotesis deskriptif

Daya tahan berdiri karyawan toko lulusan SMK sama dengan 6 jam/hari $\left(\mathrm{H}_{0}\right)$. Ini merupakan hipotesis nol, karena daya tahan berdiri karyawan lulusan SMK yang ada pada sampel diharapkan tidak berbeda secara signifikan dengan daya tahan yang ada pada populasi. (angka 6 jam/hari merupakan angka hasil 
pengamatan sementara). Hipotesis alternatifnya adalah: Daya tahan karyawan toko lulusan SMK $\neq 6$ jam. "Tidak sama dengan" ini bisa berarti lebih besar atau lebih kecil dari 6 jam.

3) Hipotesis statistik (hanya ada bila berdasarkan data sampel)

$$
\begin{aligned}
& \mathrm{H}_{1}: \quad \mu=6 \mathrm{jam} / \mathrm{hari} \\
& \mathrm{H}_{i}: \quad \mu \neq 6 \mathrm{jam} / \mathrm{hari} \\
& \mu: \quad \begin{array}{l}
\text { Adalah nilai rata-rata populasi yang dihipotesiskan } \\
\text { atau ditaksir melalu sampel }
\end{array}
\end{aligned}
$$

Untuk rumusan masalah b) hipotesis nol bisa berbentuk demikian.

a. Semangat belajar mahasiswa perguruan tinggi negeri $=75 \%$ dari kriteria ideal yang ditetapkan.

b. Semangat belajar mahasiswa perguruan tinggi negeri paling sedikit $60 \%$ dari kriteria ideal yang ditetapkan (paling sedikit itu berarti lebih besar atau sama dengan $\geq$ ).

c. Semangat belajar mahasiswa perguruan tinggi negeri paling banyak $60 \%$ dari kriteria idela yang ditetapkan (paling banyak itu berarti lebih kecil atau sama dengan $\leq$ ).

Dalam kenyataan hipotesis yang diajukan salah satu saja, dan hipotesis mana yang dipilih tergantung pada teori dan pengamatan pendahuluan yang dilakukan pada obyek. Hipotesis alternatifnya masing-masing adalah:

a. Semangat belajar mahasiswa perguruan tinggi negeri $\neq 75 \%$

b. Semangat belajar mahasiswa perguruan tinggi negeri $<75 \%$

c. Semangat belajar mahasiswa perguruan tinggi negeri $>75 \%$

Hipotesis statistik adalah (hanya ada bila berdasarkan data sampel)
A $\mathrm{H}_{0}: \rho=75 \%$
$\mathrm{H}_{0}: \rho \neq 75 \%$
b $\quad \mathrm{H}_{0}: \rho \geq 75 \%$
$\mathrm{H}_{0}: \rho<75 \%$
c $\quad \mathrm{H}_{0}: \rho \leq 75 \%$
$\mathrm{H}_{0}: \rho>75 \%$
$\rho=$ hipotesis berbentuk persentase 
Teknik statistik yang digunakan untuk menguji ketiga hipotesis tersebut tidak sama. Cara-cara pengujian hipotesis akan diberikan pada bab tersendiri yaitu analisis data.

\section{Hipotesis komparatif}

Hipotesis komparatif merupakan jawaban sementara terhadap rumusan masalah komparatif. Pada rumusan ini, variabelnya sama tetapi populasi atau sampelnya yang berbeda, atau keadaan itu terjadi pada waktu yang berbeda.

\section{Contoh:}

1) Rumusan masalah komparatif

Bagaimana prestasi belajar mahasiswa Perguruan Tinggi X bila dibandingkan dengan Perguruan Tinggi Y?

2) Hipotesis komparatif

Berdasarkan rumusan masalah komparatif tersebut dapat dikemukakan tiga model hipotesis nol dan alternatif sebagai berikut: Hipotesis nol

a. $\quad \mathrm{H}_{0} \quad$ : Tidak terdapat perbedaan prestasi belajar mahasiswa Perguruan Tinggi X dengan Perguruan Tinggi Y; atau terdapat persamaan prestasi belajar antara mahasiswa Perguruan Tinggi X dan Y.

b. $\quad \mathrm{H}_{0} \quad$ : Prestasi belajar mahasiswa Perguruan Tinggi $X$ lebih besar atau sama dengan $(\geq)$ Perguruan Tinggi $Y$ (lebih besar atau sama dengan $=$ paling sedikit).

c. $\quad \mathrm{H}_{0} \quad$ : Prestasi belajar mahasiswa Perguruan Tinggi $X$ lebih kecil atau sama dengan $(\leq)$ Perguruan Tinggi Y (lebih kecil atau sama dengan $=$ paling besar).

Hipotesis alternatif

a. $\quad \mathrm{H}_{\mathrm{a}} \quad$ : Prestasi belajar mahasiswa Perguruan Tinggi X lebih besar (atau lebih kecil) dari Perguruan Tinggi Y.

b. $\quad \mathrm{H}_{\mathrm{a}} \quad$ : Prestasi belajar mahasiswa Perguruan Tinggi X lebih kecil dari pada $(<)$ Perguruan Tinggi Y.

c. $\quad \mathrm{H}_{\mathrm{a}}$ : Prestasi belajar mahasiswa Perguruan Tinggi $X$ lebih besar dari pada $(\geq)$ Perguruan Tinggi Y. 
3) Hipotesis statistik

$$
\begin{aligned}
& \text { a } \mathrm{H}_{0}: \mu_{1}=\mu_{2} \\
& \mathrm{H}_{0}: \mu_{1} \neq \mu_{2} \\
& \text { b } \quad \mathrm{H}_{0}: \mu_{1} \geq \mu_{2} \\
& \mathrm{H}_{0}: \mu_{1}<\mu_{2} \\
& \text { c } \mathrm{H}_{0}: \mu_{1} \leq \mu_{2} \\
& \mathrm{H}_{0}: \mu_{1}>\mu_{2} \\
& \mu_{1}=\text { rata-rata (populasi) Perguruan Tinggi } \mathrm{X} \\
& \mu_{2}=\text { rata-rata (populasi) Perguruan Tinggi } Y
\end{aligned}
$$

\section{Hipotesis asosiatif}

Hipotesis asosiatif adalah jawaban sementara terhadap rumusan masalah asosiatif, yaitu yang menanyakan hubungan antara dua variabel atau lebih.

Contoh:

1) Rumusan masalah asosiatif

Adakah hubungan yang positif dan signifikan antara kepemimpinan kepala sekolah dengan iklim kerja sekolah.

2) Hipotesis penelitian

Tedapat hubungan yang positif dan signifikan antara kepemimpinan kepala sekolah dengan iklim kerja sekolah,

3) Hipotesis statistik

$$
\begin{aligned}
& \mathrm{H}_{0}: \rho=0, \quad--------0 \quad \text { Berarti tidak ada hubungan } \\
& \mathrm{H}_{0} \quad: \quad \rho \neq 0, \quad--------\quad \neq 0 \quad \text { Berarti lebih besar atau kurang } \\
& (-) \text { dari nol berarti ada } \\
& \text { hubungan } \\
& \rho=\text { nilai korelasi dalam } \\
& \text { formulasi yang dihipotesiskan }
\end{aligned}
$$

\section{b) Menerima dan menolak hipotesis}

Hasil uji hipotesis pada analisis statistika, biasanya selalu jatuh pada dua kemungkinan yaitu menerima atau menolak. 


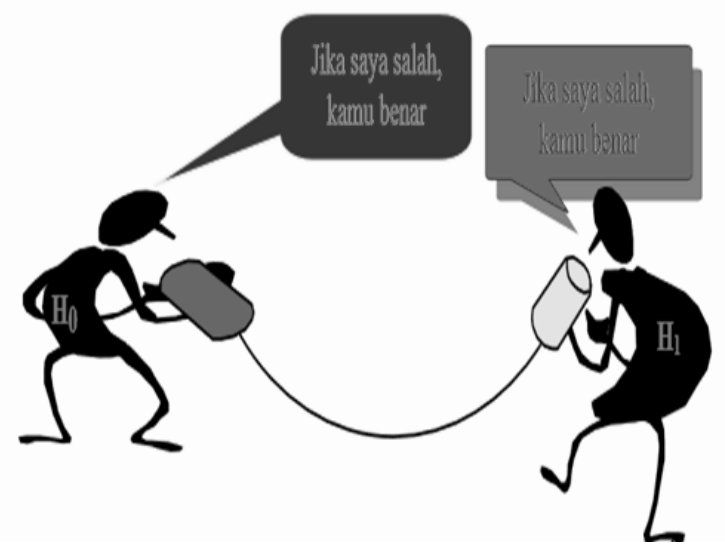

Gambar 5.4. Pengambilan Keputusan dalam Membuat Hipotesis

Suatu uji hipotesis dikatakan menolak, jika dari uji statistika yang dilakukan, peneliti memperoleh hasil akhir bahwa hipotesis nol $\left(\mathrm{H}_{\mathrm{o}}\right)$ yang diajukan oleh si peneliti ditolak pada derajat signifikan tertentu. Hasil uji statistika ini dengan kata lain dapat diartikan bahwa adanya perbedaan hasil variabel yang terjadi bukan disebabkan oleh suatu kebetulan, tetapi memang didukung dengan data yang ada di lapangan. Interpretasi uji hipotesis pula diartikan dengan melihat sisi lain yang diajukan oleh peneliti, yaitu hipotesis kerja. Hasil testing statistika menunjukan bahwa hipotesis penelitian yang telah ada didukung atau diterima sebagai hal yang benar.

Hipotesis nol $\left(\mathrm{H}_{\mathrm{o}}\right)$ diterima, jika $\mathrm{H}_{\mathrm{o}}$ yang diturunkan dari hasil kesimpulan kajian teori tidak ditolak atau diterima. Jika ternyata uji statistik menerima $\mathrm{H}_{\mathrm{o}}$, hal ini berarti bahwa perbedaan yang dihasilkan dari proses hasil kajian pustaka, hanyalah disebabkan oleh suatu kebetulan saja atau oleh suatu kebetulan saja atau oleh adanya kesalahan yang tidak disengaja waktu mengambil data dilapangan.

Atau dari hasil uji hipotesis diperoleh kesimpulan bahwa, hipotesis penelitian yang telah diajukan oleh si peneliti sebagai hipotesis kerja, ditolak atau tidak didukung oleh informasi yang ada.

c) Kekeliruan yang terjadi dalam pengujian hipotesis

Benar dan tidaknya hipotesis tidak ada hubungannya dengan terbukti dan tidaknya hipotesis tersebut. Mungkin seorang peneliti merumuskan hipotesis yang isinya benar, tetapi setelah data terkumpul dan dianalisis ternyata hipotesis tersebut ditolak, atau tidak terbukti. Sebaliknya mungkin seorang peneliti merumuskan sebuah hipotesis yang salah, tetapi setelah dicocokan 
dengan datanya, hipotesis yang salah tersebut terbukti. Keadaan ini akan berbahaya, apabila mengenai hipotesis tentang sesuatu yang berbahaya.

\section{Contoh:}

Belajar tidak mempengaruhi prestasi. Dari data yang terkumpul, memang ternyata anak-anak yang tidak belajar dapat lulus. Maka ditarik kesimpulan bahwa hipotesis tersebut terbukti.

Tentu saja kesimpulan ini salah menurut norma umum. Pembuktian hipotesis mungkin benar. Akibatnya bisa berbahaya apabila disimpulkan oleh siswa atau mahasiswa bahwa tidak ada gunanya mereka belajar. Yang salah adalah perumusan hipotesisnya. Dalam hal lain dapat terjadi perumusan hipotesis benar tetapi ada kesalahan dalam pengambilan keputusan. Apabila terjadi hal yang demikian kita tidak boleh menyalahkan hiptesis.

Kesalahan penarikan kesimpulan tersebut barangkali disebabkan karena kesalahan sampel, kesalahan perhitungan ada pada variabel dan prestasi yang pada saat pengujian hipotesis ikut berperan.

Misalnya:

Faktor untung-untungan, faktor soal tes yang sudah bocor, faktor menyontek, dan sebagainya.

Untuk memperjelas keterangan, berikut ini disampaikan matriks macam kekeliruan ketika membuat kesimpulan tentang hipotesis pada umumnya.

Matriks 5.1. Macam Kekeliruan membuat Kesimpulan tentang Hipotesis

\begin{tabular}{|c|l|l|}
\hline \multirow{2}{*}{$\begin{array}{c}\text { Kesimpulan dan } \\
\text { Keputuan }\end{array}$} & \multicolumn{2}{|c|}{ Keadaan Sebenarnya } \\
\cline { 2 - 3 } & \multicolumn{1}{|c|}{ Hipotesis benar } & \multicolumn{1}{|c|}{ Hipotesis salah } \\
\hline Terima Hipotesis & $\begin{array}{l}\text { Tidak membuat } \\
\text { kekeliruan }(1-\alpha)\end{array}$ & Kekeliruan macam II $(\beta)$ \\
\hline Tolak Hipotesis & Kekeliruan macam I $(\alpha)$ & $\begin{array}{l}\text { Tidak membuat } \\
\text { kekeliruan }(1-\beta)\end{array}$ \\
\hline
\end{tabular}

(Arikunto, 2010)

Probabilitas melakukan kekeliruan macam I dinyatakan dengan $\alpha$ (alpha), sedangkan melakukan kekeliruan macam II dinyatakan dengan $\beta$ (beta). Misalnya $\alpha=1 \%$ berarti bahwa jika kita menerapkan kesimpulan penelitian kita, akan ada penyimpangan sebanyak $1 \%$. Besar kecilnya resiko kesalahan kesimpulan ini tergantung dari keberanian peneliti, atau kesediaan peneliti mengalami kasalahan tipe I.

Kesalahan tipe I ini disebut taraf signifikansi pengetesan, artinya kesediaan yang bewujud besarnya probabilitas jika hasil penelitian terhadap sampel akan 
diterapkan pada populasi. Besarnya taraf signifikansi ini pada umumnya sudah diterapkan terlebih dahulu misalnya $0.15 ; 0.5 ; 0.1$, dan sebagainya.

Pada umumnya penelitian-penelitian dibidang ilmu pendidikan digunakan taraf signifikansi 0.05 atau 0.01 , sedangkan untuk peneliti obat-obatan yang resikonya menyangkut jiwa manusia, diambil 0.005 atau 0.001 , bahkan mungkin 0.0001 .

Apabila peneliti menolak hipotesis atas dasar taraf signifikansi 5\% berarti sama dengan menolak hipotesis atas dasar taraf kepercayaan 95\%, artinya apabila kesimpulan tersebut diterapkan pada populasi yang terdiri dari 100 orang, akan cocok untuk 95 orang dan bagi 5 orang lainnya terjadi penyimpangan.

\section{d) Karakteristik hipotesis yang baik}

1. Merupakan dugaan terhadap keadaan variabel mandir, perbandingan keadaan variabel pada berbagai sampel, dan merupakan dugaan tentang hubungan antara dua variabel atau lebih. (pada umumnya hipotesis deskriptif tidak dirumuskan).

2. Dinyatakan dalam kalimat yang jelas, sehingga tidak menimbulkan berbagai penafsiran.

3. Dapat diuji dengan data yang dikumpulkan dengan metodemetode ilmiah.

\section{KASUS}

Petunjuk: berikut ini merupakan pertanyaan penelitian tentang: apakah siswasiswa yang belajarnya teratur memiliki hasil belajar yang lebih baik daripada siswa yang cara belajarnya kurang teratur.

Tugas:

1. Rumuskan hipotesisnya

2. Gambarkan model hipotesis yang digunakan

3. Gambarkan paradigma teori yang dipergunakan

\section{PARADIGMA PENELITIAN, RUMUSAN MASALAH, DAN HIPOTESIS}

Pada bab dua telah disampaikan ragam penelitian. Dengan ragam penelitian itu, peneliti dapat menggunakan sebagai panduan untuk rumusan masalah, dan hipotesis penelitiannya, yang selanjutnya dapat digunakan untuk panduan dalam pengumpulan data dan analisis.

Pada setiap paradigma penelitian minimal terdapat satu rumusan masalah penelitian contohnya masalah deskriptif. Berikut ini contoh judul penelitian, jenis penelitian, rumusan masalah dan hipotesis penelitian. 


\section{Judul penelitian}

Hubungan antar gaya kepemimpinan Kepala Sekolah dengan prestasi belajar siswa. (gaya kepemimpinan adalah variabel independen $(\mathrm{X})$ dan prestasi kerja adalah variabel dependen $(\mathrm{Y})$ ).

2. Paradigma penelitian

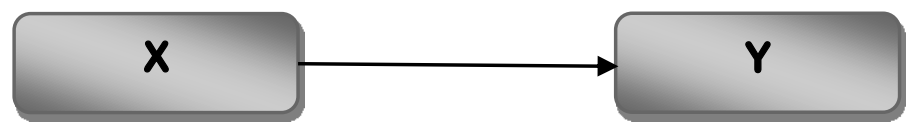

\section{Rumusan masalah}

a. Seberapa baik gaya kepemimpinan Kepala Sekolah yang ditampilkan? (bagaimana X?).

b. Seberapa baik prestasi belajar siswa? (bagaimana Y?).

c. Adakah hubungan yang positif dan signifikan antara gaya kepemimpinan Kepala Sekolah dengan prestasi belajar siswa? (adakah hubungan antar X dan Y). Butir ini merupakan rumusan masalah asosiatif.

d. Bila sampel penelitiannya golongan guru III dan IV maka rumusan masalah komparatifnya adalah :

1) Adakah perbedaan persepsi antara guru Golongan III, dan IV tentang kepemimpinan Kepala Sekolah?.

2) Adakah perbedaan persepsi antara guru Goolongan III, dan IV tentang prestasi belajar siswa.

\section{Rumusan hipotesis penelitian}

1) Gaya kepemimpinan yang ditampilkan Kepala Sekolah (X) ditampilkan kurang baik, dan nilainya paling tinggi $60 \%$ dari kriteria yang diharapkan.

2) Prestasi belajar siswa (Y) kurang memuaskan, dan nilainya paling tinggi 65.

3) Terdapat hubungan yang positif dan signifikan antara gaya kepemimpinan Kepala Sekolah dengan prestasi belajar siswa, artinya makin baik kepemimpinan Kepala Sekolah, maka akan semakin baik prestasi belajar siswa.

4) Terdapat perbedaan persepsi tentang gaya kepemimpinan antara golongan III, dan IV.

5) Terdapat perbedaan persepsi tentang prestasi kerja antara guru Golongan III dan IV.

Untuk bisa diuji dengan statistik, maka data yang akan didapatkan harus diangkakan. Untuk bisa diangkakan, maka diperlukan instrumen yang memiliki 
skala pengukuran. Untuk judul di atas ada dua instrumen, yaitu instrumen gaya kepemimpinan Kepala Sekolah dan prestasi belajar siswa.

Untuk judul penelitian yang berisi dua variabel independen atau lebih, rumusan masalah penelitiannya akan lebih banyak, demikian juga rumusan hipotesisnya (lihat bagian paradigma penelitian) dan dibagian analisis data.

\section{LATIHAN}

1. Mengapa teori diperlukan dalam penelitian pendidikan?.

2. Jelaskan keterkaitan antara teori penelitian dengan variabel penelitian!

3. Bagaimana kerangka teoritis pada sebuah penelitian? dan mengapa penelitian perlu mengandalkan referensi? Jelaskan dengan lengkap disertai contoh.

4. Mengapa peneliti perlu melakukan hasil kajian yang relevan?

5. Jelaskan kegunaan hipotesi penelitian!.

6. Bagaimana membedakan antara hipotesis penelitian dengan hipotesis statistik?

7. Dalam suatu proses penelitian, bagaimanakah hubungan antara kedua macam hipotesis tersebut?

\section{RANGKUMAN}

Setelah masalah penelitian dirumuskan, maka langkah kedua dalam proses penelitian adalah adalah mencari teori-teori, konsep-konsep dan generalisasigeneralisasi hasil penelitian yang dapat dijadikan sebagai landasan teoritis. Landasan-landasan teori ini perlu ditegakan agar penelitian itu mempunyai dasar yang kokoh, dan bukan sekedar perbuatan coba-coba (trial and error). Adanya landasan teoritis ini merupakan ciri bahwa penelitian itu merupakan cara ilmiah untuk mendapatkan data. Seorang peneliti harus menguasai teoriteori ilmiah sebagai dasar bagi argumentasi dalam menyusun kerangka pemikiran yang membuahkan hipotesis. Ada banyak cara yang dapat digunakan sebagai bahan studi kepustakaan yaitu sumber data primer dan sekunder. Tidak ada batasan pasti tentang berapa jumlah buku yang harus digunakan sebagai acuan, semakin banyak buku dan sumber informasi yang mendukung maka semakin baik dan menguntungkan bagi peneliti. Sitasi (citation) di dalam penulisan ilmiah sangat penting. Sitasi menunjukkan asalusul atau sumber suatu kutipan, mengutip pernyataan, atau menyalin/mengulang pernyataan seseorang dan mencantumkannya di dalam suatu karya tulis yang dibuat, namun tetap mengindikasikan bahwa kutipan tersebut itu adalah pernyataan orang lain.

Dalam suatu penelitian, dapat terjadi ada hipotesis penelitian, tetapi tidak ada hipotesis statistik. Hipotesis merupakan jawaban sementara terhadap 
rumusan masalah dan hipotesis yang akan diuji ini dinamakan hipotesis kerja. Sebagai lawannya adalah hipotesis nol (nihil). Hipotesis kerja disusun berdasarkan atas teori yang dipandang handal, sedangkan hipotesis nol dirumuskan karena teori yang digunakan masih diragukan kehandalannya. Benar dan tidaknya hipotesis tidak ada hubungannya dengan terbukti dan tidaknya hipotesis tersebut. Mungkin seorang peneliti merumuskan hipotesis yang isinya benar, tetapi setelah data terkumpul dan dianalisis ternyata hipotesis tersebut ditolak, atau tidak terbukti. Sebaliknya mungkin seorang peneliti merumuskan sebuah hipotesis yang salah, tetapi setelah dicocokan dengan datanya, hipotesis yang salah tersebut terbukti. Keadaan ini akan berbahaya, apabila mengenai hipotesis tentang sesuatu yang berbahaya.

\section{TUGAS}

1. Uraikan secara jelas analisis Anda mengenai teori-teori pendidikan. Buatlah dalam bentuk makalah dengan bagian pokok yang harus ada adalah Pendahuluan, Isi, dan Kesimpulan.

2. Uraikan secara jelas analisis Anda mengenai jenis-jenis hipotesis, pengujian hipotesis, kekeliruan dalam pengujian hipotesis. Buatlah dalam bentuk makalah dengan bagian pokok yang harus ada adalah Pendahuluan, Isi, dan Kesimpulan.

3. Berdasarkan masalah yang telah dirumuskan menjadi judul penelitian pada tugas sebelumnya, Anda akan membuat Studi Pustaka yang relevan dari judul penelitian tersebut. 


\section{BAB 6 \\ DESAIN PENELITIAN}

etelah masalah penelitian ditentukan serta rasional yang mendasari penelitian telah ditemukan, langkah selanjutnya yang harus dilakukan oeh seorang peneliti adalah mendapatkan informasi atau data untuk menjawab masalah tersebut. Langkah ini harus didesain sedemikian rupa sehingga data yang diperoleh cukup akurat dan relevan dengan permasalahan penelitian. Desain sangat penting sebagai acuan untuk menentukan bagaimana data harus dianalisis dan bagaimana hasilnya harus diinterpretasikan. Desain mengacu pada rencana dan struktur penyelidikan yang digunakan untuk memperoleh bukti-bukti empiris dalam menjawab masalah penelitian. Beragam desain penelitian yang dihasilkan dari sudut pandang yang berbeda. Namun demikian, pemilihan desain yang tepat bersifat mutlak karena dapat meningkatkan reliabilitas dan validitas serta kredibilitas dan autensitas penelitian. Pada bab ini akan dibicarakan sub bab tentang tentang jenis-jenis desain yang menggambarkan langkah-langkah pemilihan subyek penelitian pendidikan. Kemampuan akhir yang diharapkan setelah mahasiswa mempelajari bab ini yaitu:

1. Menganalisis jenis-jenis desain penelitian pendidikan

2. Merumuskan rancangan penelitian sesuai dengan permasalahan penelitian yang diangkat

3. Membuat skema desain penelitian sesuai dengan permasalahan penelitian

4. Memberikan contoh desain penelitian dibidang pendidikan

\section{A. DASAR DAN KOMPONEN DESAIN PENELITIAN}

Desain penelitian adalah rencana tentang cara mengumpulkan dan menganalisis data agar dapat dilaksanakan sesuai dengan tujuan penelitian. Desain penelitian memberi pegangan yang lebih jelas kepada peneliti dalam melakukan penelitiannya dan menentukan batas-batas yang jelas sesuai dengan tujuan penelitian.

Desain penelitan meliputi pemilihan subyek dari mana informasi atau data akan diperoleh, teknik yang digunakan untuk mengumpulkan data, dan prosedur yang ditempuh untuk pengumpulan data. Subyek yang bias sebagai sumber kesalahan dapat terjadi karena teknik pemilihan yang kurang tepat, sehingga subyek tidak dapat mencerminkan populasi darimana ia dipilih. Selanjutnya, instrumen yang tidak reliabel dan valid juga dapat menjadi sumber kesalahan, karena tidak dapat menghasilkan data yang terpercaya. 
Instrumen yang tidak valid tidak dapat mengukur karakteristik subyek, sehingga hasil yang diperoleh akan bias, tidak mencerminkan karakteristik (kenyataan) yang sebenarnya. Sedang instrumen yang tidak reliabel tidak dapat menghasilkan ukuran yang sama bila dilakukan pengulangan, sehingga hasil tersebut cenderung tidak konsisten.

Kondisi pengumpulan data dapat menjadi sumber kesalahan bila dalam pelaksanaannya terjadi variasi. Variasi kondisi ini dapat menjadi sumber kesalahan karena dapat memengaruhi perilaku subyek. Selain itu, tidak adanya kontrol variabel juga dapat menjadi sumber kesalahan. Dengan hanya memfokuskan pada variabel tertentu berarti peneliti telah mengabaikan variabel lain yang mungkin juga mempengaruhi dalam menjelaskan hasil penelitian.

\section{B. DESAIN EKSPERIMEN}

Eksperimen merupakan desain penelitian ilmiah yang paling teliti dan tepat untuk menyelidiki pengaruh suatu variabel terhadap variabel yang lain. Dalam penelitian eksperimental, peneliti melakukan manipulasi terhadap perlakuan yang diberikan kepada subyek. Peneliti melakukan kontrol terhadap apa yang akan dialami oleh subyek dengan cara memberi atau tidak memberi kondisi atau perlakuan tertentu secara sistematis. Dengan adanya kontrol tersebut, peneliti dapat membandingkan kelompok subyek yang mendapat perlakuan dan kelompok subyek yang tidak mendapat perlakuan. Perbandingan tersebut untuk menyelidiki hubungan sebab-akibat antara perlakuan yang dimanipulasi dan hasil yang diukur. Bila dari hasil analisis ternyata terdapat perbedaan hasil yang signifikan antara kedua kelompok, maka dapat disimpulkan bahwa perlakuan yang dimanipulasi tersebut mempunyai pengaruh terhadap hasil yang diperoleh subyek.

\section{Ruang lingkup penelitian}

Penelitian eksperimen atau penelitian percobaan dibedakan menjadi dua yaitu eksperimen murni dan eksperimen kuasi. Penelitian eksperimen murni mengambil subjek penelitian berupa benda atau hewan percobaan. Penelitian dilaksanakan di laboratorium dan kondisi lingkungan laboratorium yang dapat mempengaruhi hasil penelitian dikendalikan oleh peneliti. Dengan demikian, hasil akhir penelitian adalah murni karena ada pengaruh dari percobaan/eksperimen.

Penelitian kuasi eksperimen (PKE) atau eksperimen semu mengambil subjek penelitian pada manusia. Kondisi lingkungan yang dapat mempengaruhi hasil penelitian tidak dapat dikendalikan oleh peneliti sehingga hasil penelitian tidaklah murni dari eksperimen/percobaan yang dilakukan. 
Metode penelitian eksperimen murni banyak digunakan pada penelitian dasar (basic research) sedangkan metode penelitian kuasi eksperimen banyak digunakan pada penelitian terapan (applied research). Penelitian eksperimen murni berfungsi untuk menemukan dasar teori tentang pengaruh percobaan terhadap karakteristik benda atau hewan percobaan yang sedang diteliti. Penelitian eksperimen kuasi berfungsi untuk mengetahui pengaruh percobaan/perlakuan terhadap karakteristik subjek yang diinginkan oleh peneliti. Dengan demikian, penelitian eksperimen murni maupun kuasi memiliki maksud yang sama yaitu menguji pengaruh percobaan terhadap karakteristik subjek setelah percobaan.

\section{Desain penelitian eksperimen semu}

Penempatan subyek kedalam kelompok yang dibandingkan pada desain ini tidak dilakukan secara acak. Individu subyek sudah berada dalam kelompok yang akan dibandingkan sebelum adanya penelitian. Desain ini sangat lazim dan berguna dalam pendidikan, karena tidak mungkin untuk menempatkan subyek secara acak. Peneliti menggunakannya secara utuh kelompok subjek yang telah ditentukan. Mereka diorganisasikan dalam kelompoknya untuk tujuan lain, misalnya siswa yang berada dalam kelas atau sekolah biasa. Peneliti memanipulasi perlakuan pada kelompok eksperimen dan memberikan perlakuan biasa terhadap kelompok kontrol.

Desain 6.1. Desain Statis dengan dua Kelompok

\begin{tabular}{|c|c|c|}
\hline Kelompok & Variabel bebas & Posstest \\
\hline E & $\mathrm{X}$ & $\mathrm{Y} 2$ \\
\hline $\mathrm{K}$ & - & $\mathrm{Y} 2$ \\
\hline
\end{tabular}

(Hasnunidah, 2017)

Desain ini diawali dengan pemilihan dua kelompok subyek yang sudah terbentuk tanpa ikut campur peneliti, misalnya dua sekolah, dua kelas paralel. Langkah selanjutnya, peneliti memberikan perlakuan eksperimental kepada salah satu kelompok dan kemudian memberikan posstest. Sedangkan pada kelompok lain hanya memberikan postes saja. Hasil posstest dari kedua kelompok kemudian dibandingkan untuk diuji perbedaannya.

Kelemahan desain ini adalah tidak menggunakan randomisasi dalam menempatkan subyek ke dalam kelompok sampel dan kelompok kontrol. Asumsi bahwa kedua kelompok sampel tersebut sama sebelum perlakuan tidak dapat kita gunakan. Kedua kelompok sampel mungkin berbeda dalam 
beberapa variabel relevan tertentu, dan perbedaan inilah yang dapat mempengaruhi variabel terikat.

Desain 6.2. Desain Pretest-Postest kelompok Non-ekuvalen

\begin{tabular}{|c|c|c|c|}
\hline Kelompok & Pretest & Variabel bebas & Postest \\
\hline E & Y1 & X & Y2 \\
\hline K & Y1 & - & Y2 \\
\hline
\end{tabular}

(Hasnunidah, 2017)

Desain di atas memberikan gambaran langkah-langkah dalam penelitian eksperimental semu, yaitu: Pertama, peneliti memilih dua kelompok subyek yang sedapat mungkin tidak mempunyai perbedaan kondisi yang berarti. Kedua, peneliti memberikan pretest kepada kedua kelompok subyek untuk mengontrol perbedaan kondisi awal keduanya. Langkah ketiga, peneliti memberikan perlakuan eksperimen (X) kepada salah satu kelompok dan membiarkan kelompok lain (kontrol) tanpa perlakuan. Keempat, setelah perlakuaan eksperimental diberikan, kedua kelompok subyek diberi postest dengan menggunakan tes yang sama sebagaimana yang digunakan pada pretest. Selanjutnya kelima, peneliti membandingkan perubahan/perbedaan antara skor pretest dan postest antara kelompok ekperimen dan kelompok kontrol.

\section{Judul penelitian kuasi eksperimen}

Dalam penyusunan judul penelitian, ada beberapa kata kunci yang dapat digunakan yaitu ada masalah dan ada perlakuan untuk mengatasi masalah. Orang awam lebih mudah mengingat dengan istilah penyakit dan obat. Penyakit identik dengan masalah yang akan diatasi sedangkan obat identik dengan perlakuan yang digunakan untuk mengatasi masalah. Indikator keberhasilan eksperimen diukur dari pengaruh, efektivitas, perbedaan. 

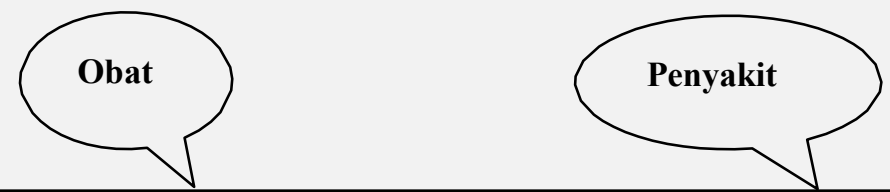

Pengaruh pendekatan PMRI terhadap hasil belajar matematika

siswa kelas VII SMP N I Masohi.

Atau

Efektivitas penggunaan pendekatan PMRI untuk meningkatkan hasil belajar matematika siswa kelas VII SMP N I Masohi.

Atau

Perbedaan hasil belajar matematika siswa kelas VII SMP N I

Masohi setelah menggunakan pendekatan PMRI.

Contoh 6.1. Rangkaian kalimat pada judul penelitian Eksperimen Kuasi Pada contoh judul penelitian pertama tentang "Pengaruh pendekatan PMRI terhadap hasil belajar matematika siswa kelas VII SMP N I Masohi" mengindikasikan bahwa masalah yang akan diatasi oleh guru adalah hasil belajar matematika siswa yang cenderung rendah. Guru memilih pendekatan PMRI untuk mengatasinya. Dengan kata lain guru menemukan penyakit kurangnya rasa percaya diri pada siswa dan mencoba mengobatinya dengan penerapan pendekatan PMRI.

\section{Variabel peneltian}

Penelitian eksperimen memiliki tiga variabel yaitu variabel bebas (independen), variabel terikat (dependen) dan variabel kontrol. Variabel independen merupakan variabel yang kedudukannya memberi pengaruh terhadap variabel dependen, dapat dimanipulasi, diubah, atau diganti. Variabel dependen adalah variabel yang dipengaruhi oleh variabel independen. Variabel kontrol adalah variabel yang tidak diberi perlakuan/eksperimen namun selalu diikutsertakan dalam proses penelitian.

Dalam penelitian eksperimen, variabel independen adalah perlakuan (treatment) sedangkan variabel dependen adalah karakteristik yang diukur setelah perlakuan. Oleh karena variabel harus dapat diukur dan memiliki variasi, maka yang berlaku sebagai variabel bebas penelitian kuasi eksperimen adalah karakteristik yang diukur dari kelompok subjek sebelum mendapat perlakuan. Variabel terikat berupa karakteristik subjek yang diukur setelah 
mendapat perlakuan. Variabel kontrol adalah karakeristik kelompok subjek yang tidak diberi perlakuan tetapi turut diukur atau diambil datanya sebelum maupun sesudah eksperimen.

Karakteristik subjek yang diukur antara lain dapat berupa perilaku, kemampuan atau kompetensi tertentu. Kelompok subjek dalam penelitian kuasi eksperimen dapat berwujud kelas atau rombongan belajar, kelompok belajar, kelompok organisasi dan sebagainya.

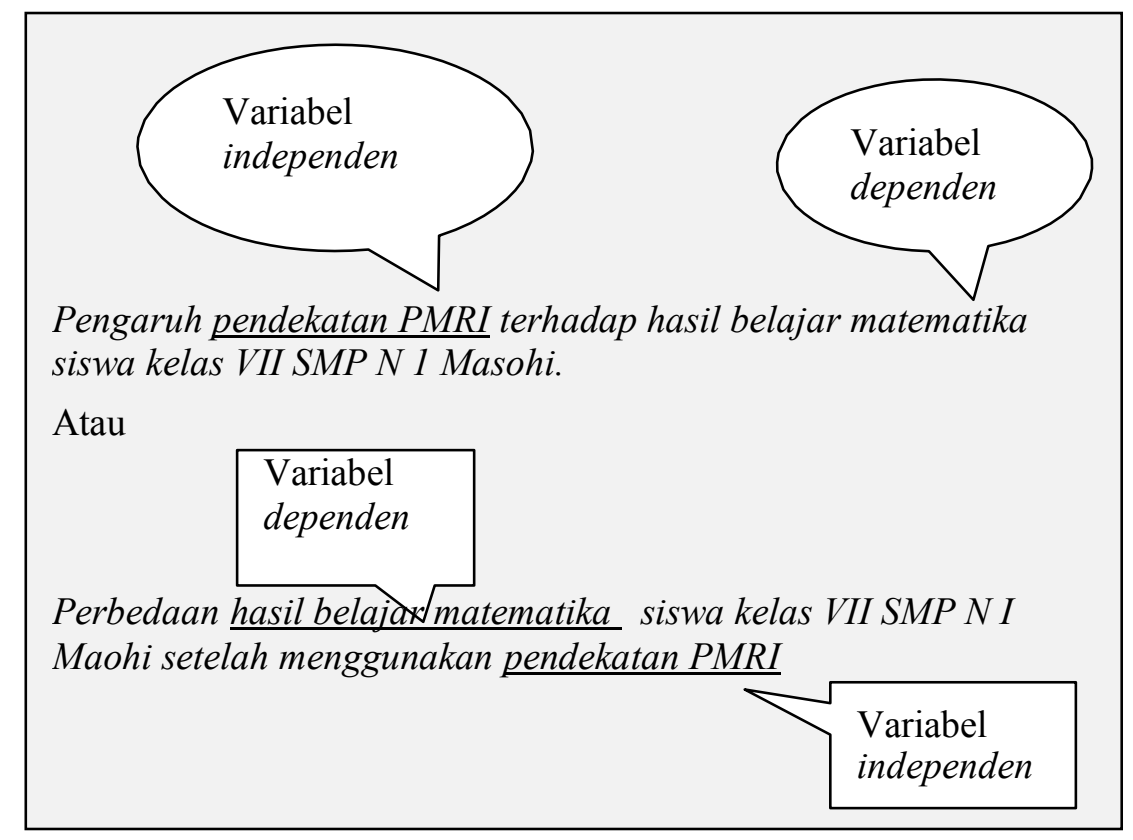

Contoh 6.2. Letak variabel Independen dan Dependen pada judul penelitian

Pada contoh judul penelitian di atas, pendekatan PMRI sebagai variabel independen diharapkan mempengaruhi hasil belajar matematika siswa. Variabel independen dapat diubah-ubah sehingga untuk meningkatkan hasil belajar matematika siswa bisa dilakukan dengan pendekatan lain sebagai variabel bebasnya misalnya diskusi, pemberian reward. Pendekatan PMRI tidak memiliki variasi yang dapat diukur sehingga variasi yang diukur adalah rasa percaya diri siswa sebelum mendapat pendekatan PMRI sebagai variabel independen dan hasil belajar matematika siswa sesudah mendapat pendekatan PMRI sebagai variabel dependen.

Penelitian eksperimen menguji hubungan sebab akibat antar variabel independen (bebas) yang terdapat pada objek percobaan dan dependen (terikat) yang terdapat pada karakteristik subjek yang telah diberi 
ujicoba/perlakuan. Untuk mengetahui efektivitas eksperimen maka digunakan variabel kontrol (variabel yang tidak diberi perlakuan). Penelitian kuasi eksperimen dinyatakan efektif apabila kelompok yang diberi perlakuan memperoleh hasil yang lebih baik dari kelompok yang tidak diberi perlakuan (kontrol). Contoh judul penelitian tentang "Pengaruh pendekatan PMRI terhadap hasil belajar matematika siswa VII SMP 1 Masohi", yang berlaku sebagai variabel kontrol adalah karakteristik yang diukur dari kelompok yang tidak memperoleh perlakuan pendekatan PMRI.

\section{Indikator keberhasilan}

Indikator keberhasilan penelitian eksperimen semu (kuasi ekpserimen) dikatakan efektif, jika hasil belajar kelompok perlakuan lebih baik daripada hasil belajar kelompok kontrol.

Namun demikian, hasil penelitian dapat berpeluang menemukan beberapa kasus antara lain:

a) Apabila perlakuan diterapkan pada kelompok siswa yang pandai, model pembelajaran dapat dinyatakan sangat efektif, namun kesimpulannya bias karena apapun model pembelajaran yang diterapkan pada kelompok siswa pandai cenderung mendapat respon positif dan menghasilkan prestasi yang memuaskan.

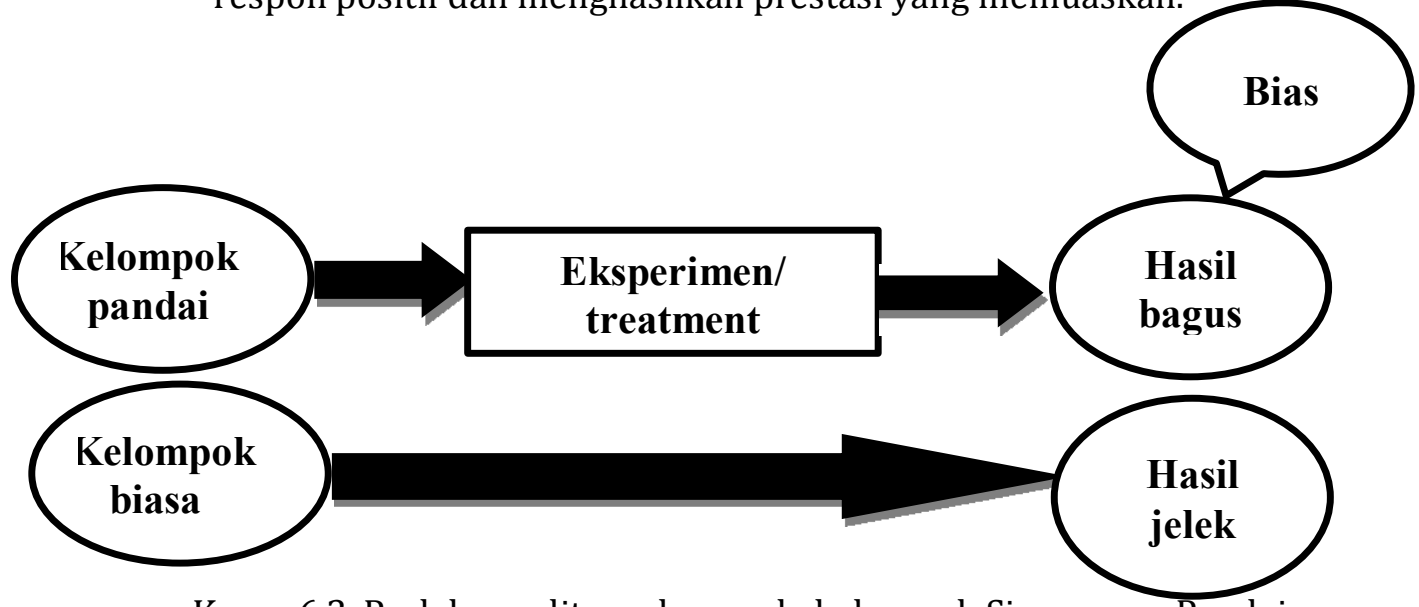

Kasus 6.3. Perlakuan diterapkan pada kelompok Siswa yang Pandai (Mulyatiningsih, 2011)

b) Hasil dapat menunjukkan tidak ada beda dan model pembelajaran dinyatakan tidak efektif apabila kelompok siswa yang dipilih untuk perlakuan adalah kelas yang siswanya kurang pandai sedangkan kelompok kontrol dipilih kelas yang siswanya lebih pandai. Kesimpulan yang diperoleh pun dapat bias karena peningkatan kemampuan kelas perlakuan tidak terlihat secara nyata. 


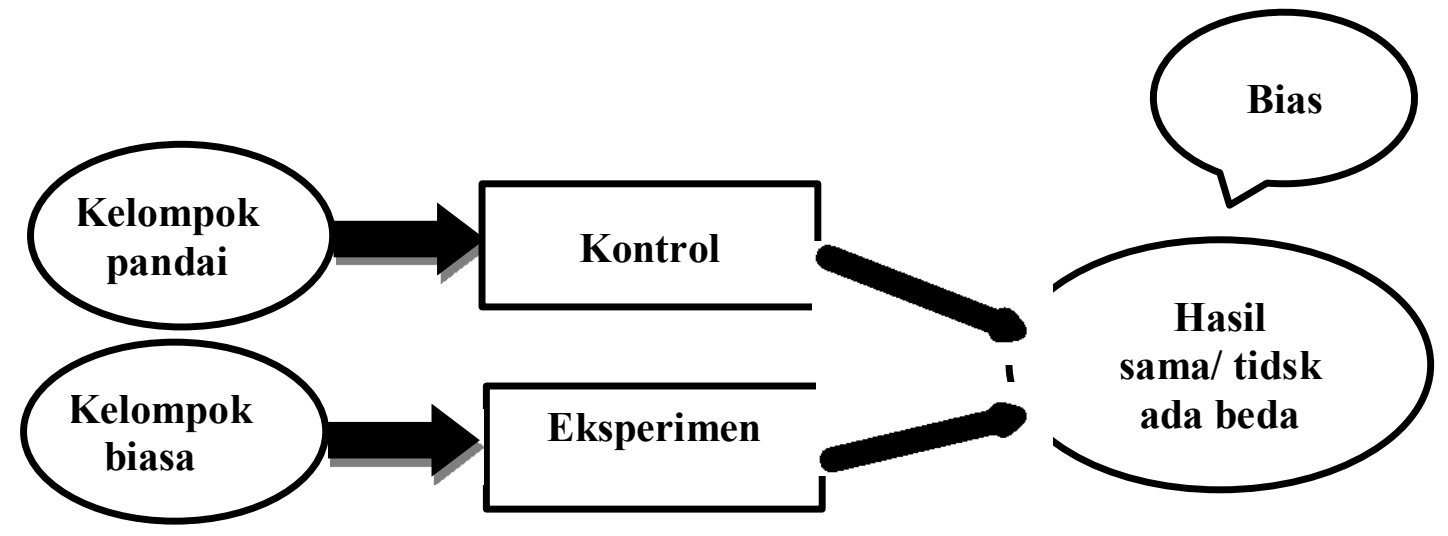

Kasus 6.2. Perlakuan diterapkan pada kelompok Siswa yang Kurang Pandai (Mulyatiningsih, 2011)

Untuk mengatasi kasus ini, peneliti dapat mengontrol perbedaan hasil melalui gain score atau peningkatan nilai sebelum dan sesudah perlakuan. Meskipun demikian, gain score juga memiliki kelemahan karena untuk siswa yang sudah mencapai skor maksimum (mendekati 100) tidak mungkin dapat meningkatkan skornya lebih tinggi lagi karena nilai 100 sudah merupakan nilai maksimum. Gain score hanya dapat digunakan untuk subjek penelitian yang memiliki kemampuan sedang atau rendah.

Dengan kasus-kasus seperti contoh di atas, maka dua kelompok yang akan dibandingkan (kelompok perlakuan dan kelompok kontrol) harus homogen atau memiliki kemampuan awal yang setara. Pengecekan asumsi ini dapat dilakukan dengan uji homogenitas varians. Asumsi yang diuji yaitu varian kelompok A sama dengan varians ke- lompok B. Apabila ada tiga kelompok yang dibandingkan maka $\mathrm{A}-\mathrm{B}=\mathrm{B}-\mathrm{C}=\mathrm{A}-\mathrm{C}$.

\section{Pengendalian ekperimen}

Dalam penelitian kuasi eksperimen, manusia tidak layak untuk dikarantina sehingga pengendalian eksperimen hanya dilakukan pada beberapa kondisi yang tampak. Untuk mengantisipasi kekurangan ini, peneliti dapat melakukan:

a) Penyetaraan kemampuan awal antara kelompok eksperimen dan kelompok kontrol. Penelitian kuasi eksperimen minimal menggunakan dua kelompok sampel, satu kelompok berlaku sebagai kelompok perlakuan dan satu kelompok lainnya berlaku sebagai kelompok kontrol. Sebelum dilakukan eksperimen, dua kelompok ini perlu disetarakan kemampuannya dengan cara memberi tugas-tugas secara acak (random assignment). Hasil pengukuran kemampuan awal ini kemudian diberi umpan balik. Kelompok yang memiliki hasil lebih rendah diberi remedial secara 
klasikal. Setelah kemampuan antar kelompok yang akan dibandingkan disetarakan kemampuannya, peneliti kemudian memulai kegiatan penelitian dengan melakukan pretest. Hasil pretest ini dapat menjadi data hasil pengukuran variabel bebas (independent) yang akan diuji pengaruhnya terhadap variabel terikatnya yaitu posttest.

b) Pengendalian validitas dan reliabilitas alat pengumpul data (instrument). Kredibilitas hasil penelitian terletak pada bagaimana cara peneliti memperoleh data penelitian. Dalam penelitian kuasi eksperimen, pengambilan data penelitian sering menggunakan alat/instrumen berupa tes, kuesioner, dan observasi. Sebelum alat pengambilan data penelitian ini digunakan perlu dilakukan pengendalian-pengendalian antara lain melalui pengendalian validitas dan reliabilitas alat pengumpul data penelitian. Pengendalian reliabilitas dan validitas tes, kuesioner, dan lembar observasi dapat dilakukan dengan berbagai cara, Metode yang sering digunakan untuk mengendalikan validitas tes, kuesioner, dan lembar observasi adalah validitas isi dan konstruk.

c) Proses eksperimen yang melibatkan lebih dari satu kelompok perlakuan harus dikendalikan. Pengendalian dilakukan dengan cara memberi perlakuan yang sama kepada semua kelompok perlakuan. Hal-hal yang dapat disamakan dalam proses belajar mengajar antara lain: metode, media, perangkat pembelajaran, durasi waktu, dan hal-hal yang bersifat teknis lainnya. Eksperimen akan lebih dipercaya hasilnya apabila orang yang memberi perlakuan juga sama atau setara kemampuannya. Sedangkan bagi kelompok kontrol, berjalan apa adanya dan tidak boleh ada intervensi dari pihak manapun. Kelompok perlakuan diberi suplemen yang mau diuji efeknya sedangkan kelompok kontrol hanya diberi suplemen yang tidak memiliki efek apapun.

\section{Sampel penelitian}

Setiap jenis penelitian membutuhkan teknik pengambilan sampel yang tepat sesuai dengan populasi sasaran yang akan diteliti. Populasi penelitian yang heterogen dan memiliki cakupan wilayah luas memerlukan sampel yang representatif sehingga perlu diambil secara acak. Populasi yang homogen tidak memerlukan teknik sampling khusus karena siapapun yang dijadikan sampel sudah mewakili. Manusia bukan populasi yang homogen sehingga perlu teknik pengambilan sampel yang tepat. Dalam penelitian kuasi 
eksperimen, terdapat dua teknik pengambilan sampel yang sering digunakan yaitu:

\section{a) Purposive sampling}

Purposive sampling digunakan apabila populasi sasaran memiliki karakteristik spesifik sehingga hanya orang-orang yang memenuhi syarat spesifik tersebut yang dapat menjadi sampel penelitian. Dalam penelitian kuasi eksperimen, purposive sampling sering dipilih apabila peneliti hanya memiliki satu kelompok populasi, sehingga tidak ada pertimbangan untuk memilih sampel yang lain. Bila teknik sampling ditetapkan secara purposive, maka kesimpulan hasil penelitian hanya berlaku bagi kelompok yang diteliti dan tidak dapat digeneralisasikan pada kelompok lain.

Contoh judul penelitian:

"Pengaruh pendekatan PMRI terhadap hasil belajar matematika siswa kelas VII SMPN 1 Masohi".

Pada judul di atas, sampel penelitian sudah spesifik yaitu siswa kelas VII SMPN 1 Masohi. Apabila kelas VII SMPN 1 Masohi hanya terdapat beberapa kelas dan semua menjadi subjek penelitian, maka sampel dapat diambil secara purposive.

\section{b) Cluster sampling}

Cluster sampling digunakan apabila populasi sasaran eksperimen cukup luas dan peneliti berkeinginan untuk mengambil sebagian populasi (sampel) yang mewakili saja. Sampel penelitian terdiri dari satuan kluster (kelompok). Dalam eksperimen pembelajaran, kluster dapat berupa rombongan belajar atau kelompok belajar.

Contoh judul penelitian:

Efektivitas penggunaan modul elektronik terhadap kemandirian belajar mata pelajaran Biologi.

Pada penelitian ini, populasi sasaran adalah rombongan belajar (kelas) yang mendapat mata pelajaran Biologi. Apabila populasi sasaran terdiri dari satu sekolah, peneliti dapat mengambil beberapa kelas yang setara atau pengajarnya sama. Apabila populasi sasaran satu wilayah kabupaten, maka peneliti dapat mengambil beberapa sekolah, kemudian tiaptiap sekolah diambil beberapa kelas secara acak. 


\section{Data hasil penelitian}

Pemilihan teknik pengumpulan data tergantung pada jenis data yang diinginkan untuk mengukur variabel penelitian. Dalam penelitian eksperimen, variabel yang diukur adalah variabel dependen atau variabel yang dipengaruhi oleh adanya eksperimen/perlakuan. Beberapa contoh variabel yang sering digunakan dan alat pengumpulan data pengukuran variabel dapat disimak pada tabel 6.1.

Tabel 6.1. Contoh variabel dan alat ukur Variabel

\begin{tabular}{|l|l|l|}
\hline No & \multicolumn{1}{|c|}{ Variabel yang Diukur } & \multicolumn{1}{c|}{ Alat Ukur } \\
\hline 1 & Prestasi belajar & Tes, dokumentasi \\
\hline 2 & Hasil belajar & Tes hasil belajar \\
\hline 3 & Kemampuan & Tes kemampuan \\
\hline 4 & Sikap, motivasi, perilaku & Observasi, kuesioner \\
\hline 5 & Keterampilan motorik & Tes unjuk kerja, observasi \\
\hline 6 & Pendapat, pemikiran, opini & Kuesioner atau wawancara \\
\hline 7 & Pendalaman kasus & wawancara dan observasi \\
\hline
\end{tabular}

(Mulyatiningsih, 2011)

\section{Teknik analisis data}

Analisis data penelitian eksperimen selalu dilakukan dengan uji beda. Apabila kelompok yang dibedakan hanya terdiri dari dua kelompok, maka teknik analisis data yang digunakan adalah t-tes. Apabila kelompok yang akan dibedakan lebih dari dua kelompok, maka analisis data yang digunakan analysis of varians (anova). Berikut ini dapat diilustrasikan beberapa teknik analisis data yang disesuaikan dengan desain eksperimennya.

\section{a) Classical experiment design}

\begin{tabular}{|l|l|l|l|}
\hline$R$ & $\mathrm{O}_{1}$ & $\mathrm{X}$ & $\mathrm{O}_{2}$ \\
\hline & $\mathrm{O}_{3}$ & & $\mathrm{O}_{4}$ \\
\hline
\end{tabular}

Desain eksperimen klasik memiliki empat kelompok data (0) yaitu data pre tes kelompok perlakuan $\left(\mathrm{O}_{1}\right)$ dan kelompok kontrol $\left(\mathrm{O}_{3}\right)$ serta data posttest kelompok perlakuan $\left(\mathrm{O}_{2}\right)$ dan kelompok kontrol $\left(\mathrm{O}_{4}\right)$. Analisis data yang digunakan untuk desain eksperimen ini menggunakan $t$-tes. Dalam analisis data $t$-tes sendiri terdapat tiga pilihan yaitu: 
1. One sample t-test digunakan untuk menguji dua set data dari kelompok sampel yang sama, misalnya data pretest dan posttest kelompok perlakuan saja atau kelompok kontrol saja.

Contoh hipotesis penelitian yang diuji misalnya: "ada perbedaan antara nilai pretest dan posttest kelompok perlakuan pada mata pelajaran ...".

2. Independen sample t-test digunakan untuk menguji dua set data dari kelompok sampel yang berbeda, misalnya data kelompok perlakuan dan kelompok kontrol.

Contoh hipotesis penelitian yang diuji misalnya : "ada perbedaan nilai posttest antara kelompok perlakuan (kelas A) dan kelompok kontrol (kelas B) pada mata pelajaran ... setelah menggunakan metode ...." atau "ada perbedaan gain score (skor posttest-skor pretest) antara kelompok perlakuan dengan kelompok kontrol".

3. Pairwise comparison digunakan untuk analisis dua set data yang berpasangan atau berkorelasi, misalnya data motivasi dan prestasi siswa sebelum dan setelah perlakuan.

Contoh hipotesis misalnya: "Ada perbedaan motivasi dan prestasi belajar sebelum dan sesudah perlakuan"

\section{b) One-group pretest-posttest}

\begin{tabular}{|l|l|l|}
\hline $\mathrm{O}_{1}$ & $\mathrm{X}$ & $\mathrm{O}_{2}$ \\
\hline
\end{tabular}

Desain eksperimen One-group pretest-posttest ini hanya memiliki 2 set data hasil pengukuran yaitu pretest $\left(\mathrm{O}_{1}\right)$ dan pengukuran posttest $\left(\mathrm{O}_{2}\right)$. Teknik analisis data yang dipilih tentu saja one sampel $t$-test.

Hipotesis yang diuji hanya satu yaitu "Ada perbedaan antara nilai rerata pretest dan nilai rerata posttest" 


\section{0) Contoh penelitian eksperimen kuasi}

Penelitian dari dengan (Lutvaidah, 2016) judul Pengaruh Metode dan Pendekatan Pembelajaran terhadap Penguasaan Konsep Matematika.

Tujuan penelitian ini adalah untuk mengetahui pengaruh metode pembelajaran dan pendekatan pembelajaran terhadap penguasaan konsep matematika siswa. Metode yang digunakan dalam penelitian ini adalah metode eksperimen. Hasil penelitian diperoleh: (1) Terdapat pengaruh yang sangat signifikan pengaruh metode pembelajaran terhadap penguasaan konsep Matematika siswa. (2) Terdapat pengaruh pendekatan pembelajaran yang signifikan terhadap penguasaan matematika siswa. (3) Tidak terdapat pengaruh yang signifikan interaksi metode pembelajaran dan pendekatan pembelajaran terhadap penguasaan konsep Matematika siswa. Hasil penelitian menunjukkan bahwa penguasaan konsep matematika dengan menggunakan metode pembelajaran Complette Sentence dan pendekatan pembelajaran konsep lebih tinggi dibandingkan dengan pendekatan pembelajaran proses.

\section{KASUS}

Petunjuk:

Mahasiswa mengkaji ulang tentang desain penelitian eksperimen kuasi kemudian menyelesaikan soal berikut ini.

Sebuah eksperimen mengenai: Penggaruh Pendekatan Pembelajaran

Matematika Realistik Indonesia terhadap Kemampuan Representasi Matematis Siswa Kelas X

SMA Kristen 1 Amahai

Tugas:

1. Pola desain ekpserimen yang kuasi yang digunakan

2. Rumusan masalah

3. Rumusan hipotesis

4. Definisi variabel

a. Variabel bebas:

b. Variabel terikat:

5. Alat ukur yang digunakan

6. Tes signifikan yang digunakan:

\section{DESAIN DESKRIPTIF}

Desain deskriptif dirancang untuk mendapatkan informasi tentang suatu gejala pada saat penelitian dilakukan. Dalam desain ini, peneliti tidak melakukan manipulasi perlakuan atau penempatan subyek, akan tetapi 
diarahkan untuk menetapkan sifat suatu situasi pada waktu penyelidikan itu dilakukan. Tujuannya adalah untuk melukiskan variabel atau kondisi "apa yang ada" dalam suatu situasi. Dalam buku ini ada 3 macam desain yang akan diuraikan, yaitu: survei, studi kasus, studi korelasi.

\section{1) Survei}

Survei merupakan prosedur dimana peneliti memberikan angket atau kuesioner pada sampel dari satu populasi untuk mendeskripsikan sikap, opini, perilaku, atau karakteritik responden. Umumnya data survai dikumpulkan dari sampel atas populasi untuk mewakili seluruh populasi. Dari hasil survei ini, peneliti membuat claim tentang kecenderungan yang ada dalam populasi. Pada umumnya yang merupakan unit analisa dalam survai adalah individu. Unit analisa ini perlu sekali diperhatikan, misalnya jika peneliti tertarik meneliti pola perkawinan dan perceraian pada tiga masyarakat, maka unit analisanya adalah individu dan bukan masyarakat. Setelah seluruh jawaban individu dianalisa, barulah dilakukan perbandingan di antara ketiga masyarakat yang diteliti.

Survei dapat digunakan untuk maksud:

a. Penjajagan (eksploratif), artinya survei bersifat terbuka, masih mencari-cari dan menggali.

b. Deskriptif, dimaksudkan untuk pengukuran yang cermat terhadap fenomena sosial tertentu, misalnya perceraian, pengangguran. Peneliti mengembangkan konsep dan menghimpun fakta, tetapi tidak melakukan pengujian hipotesis.

c. Penjelasan (explanatory), peneliti menjelaskan hubungan kausal antara variabel-veriabel melalui pengujian hipotesis.

d. Evaluasi, yang menjadi pokok pertanyaan adalah sampai seberapa jauh tujuan yang digariskan pada awal progam tercapai atau mempunyai tanda-tanda akan tercapai.

e. Prediksi atau meramalkan kejadian tertentu di masa yang akan datang.

f. Penelitian operasional, pusat perhatiannya adalah variabelvariabel yang berkaitan dengan aspek operasional suatu progam.

g. Pengembangan indikator-indikator sosial secara berkala, misalnya: indikator kesejahteraan rakyat, survei angkatan kerja nasional, dan sebagainya. 
Survei dapat dibedakan menjadi dua metode, yaitu: Longitudinal Survey dan Cross Sectional Survei. Dalam metode Longitudinal, sampel subyek yang sama dipelajari dalam jangka waktu tertentu. Peneliti yang menyelidiki perkembangan konsep-kuantitatif siswa sekolah dasar, misalnya, akan mulai dengan mengukur kecakapan-kuantitatif sekelompok siswa kelas satu, kemudian dilanjutkan dengan pengukuran kecakapan mereka setiap tahun pada setiap tingkatan kelas berikutnya. Dengan demikian, peneliti dapat menilai perkembangan kecakapan kelompok ini selama jangka waktu tertentu. Karena yang dihadapi adalah individu-individu yang sama, maka faktor seperti kemampuan sebelumnya akan tetap konstan sehingga perbedaan yang diamati di antara dua tingkatan kelas dapat ditafsirkan sebagai perubahan kuantitatifkuantitatif yang ada hubungannya dengan pertumbuhan subyek.

Metode Cross Sectional menyelidiki subyek dari berbagai tingkatan usia pada saau yang sama. Peneliti menyelidiki perkembangan kecakapan kuantitatif siswa sekolah dasar dengan sampel yang berbeda dari setiap tingkatan kelas. Dengan membandingkan ukuran yang berasal dari sampelsampel tersebut, peneliti dapat menarik kesimpulan tentang pertumbuhan anak-anak dalam hubungan dengan kecakapan tersebut. Dengan demikian, jika kita ingin menyelidiki karakteristik anak pada berbagai tahap perkembangannya lebih baik menggunakan metode Cross Sectional, karena kemungkinan mendapatkan sampel besar dengan teknik ini lebih banyak. Sementara, jika kita ingin mempelajari perubahan itu sendiri maka metode Longitudinal lebih baik, karena dapat mengikuti subyek yang sama sepanjang perkembangan mereka. Loncatan-loncatan dan masa stabil pertumbuhan yang tidak dapat diamati dalam metode Cross Sectional, akan tampak dalam metode Longitudinal.

Proses penelitian survei adalah mentransformasikan 5 komponen informasi ilmiah dengan menggunakan 6 kontrol metodologis. Komponen-komponen informasi ilmiah tersebut adalah: 1) teori, 2) hipotesis, 3) observasi, 4) generalisasi empiris, dan 5) penerimaan atau penolakan hipotesis. Kontrol metodologis adalah: 1) deduksi logika, 2) interpretasi, penyusunan instrumen, penyusunan skala dan penentuan sampel, 3) pengukuran penyederhanaan data dan perkiraaan parameter, 4) pengujian hipotesis, 5) inferensi logika, dan 6) formulasi konsep, proposisi, dan penataan proposisi.

Penelitian survei dimulai dengan munculnya minat peneliti terhadap suatu fenomena sosial tertentu. Minat ini kemudian disusun menjadi masalah penelitian yang lebih jelas dan sistematis dengan menggunakan informasi ilmiah yang sudah tersedia dalam literatur, yaitu teori. Karena teori adalah 
informasi ilmiah yang abstrak sifatnya belum tentu teori yang ada dapat langsung digunakan dalam penelitian yang dilakukan oleh seorang peneliti. Melalui deduksi teori yang abstrak tadi diterjemahkan menjadi hipotesis.

Hipotesis memberikan informasi tentang variabel-variabel penelitian serta hubungannya. Untuk mengumpulkan informasi yang cocok dengan variabel tadi, maka peneliti harus melakukan melakukan interpretasi tentang konsep yang ada dalam penelitian, konstruknya dan variabel yang dirumuskan dari konsep tersebut. Peneliti harus menentukan apakah variabel yang digunakannya itu tepat buat konsep yang ditelitinya, dan apakah instrumen penelitiannya mengukur secara lengkap konstruk dari konsep tersebut.

Populasi yang digunakan untuk survai biasanya berukuran besar, sehingga peneliti perlu menentukan sampel penelitian dengan teknik-teknik penentuan sampel yang tersedia. Dari langkah-langkah metodologis tadi peneliti memperoleh sejumlah informasi yang relevan untuk penelitiannya. Informasi itu disebut data. Data yang dikumpulkan tadi kemudiam diolah dengan metode pengolahan data yang diteliti. Dalam proses ini statistik sering digunakan karena fungsi statistik yang pokok adalah untuk menyederhanakan data. Atas data yang sudah disederhanakan itu, peneliti kemudian membuat generalisasi, empiris, atau kesimpulan-kesimpulan umum yang didasarkan atas fakta-fakta empiris tentang sampel penelitiannya.

\section{2) Studi kasus}

Peneliti berusaha menyelidiki seorang individu atau unit sosial tertentu secara mendalam. Dengan kata lain, studi kasus dapat dilakukan terhadap seorang individu, sekelompok individu (keluarga, kelompok ibu hamil, ibu menyusui, manula, balita); segolongan manusia (guru, bidan, perawat, suku Batak); lingkungan hidup manusia (desa, kota, pesisir) ; atau lembaga sosial (perkawinan-perceraian, pendidikan, agama). Unit yang menjadi kasus tersebut secara mendalam dianalisis, baik dari segi yg berhubungan dengan keadaan kasus itu sendiri, faktor-faktor yang mempengaruhi, kejadiankejadian khusus yang muncul sehubungan dengan kasus, maupun tindakan dan reaksi kasus terhadap suatu perlakuan tertentu. Melalui studi ini, peneliti dapat memperoleh wawasan yang mendalam mengenai aspek-aspek dasar perilaku manusia. Penyelidikan intensif mungkin akan mengakibatkan ditemukannya hubungan-hubungan yang tidak terduga sebelumnya.

Kebanyakan studi kasus timbul dari suatu usaha untuk memecahkan masalah. Misalnya, studi kasus Freud yang terkenal pada mulanya adalah usaha membantu para subyeknya memecahkan persoalan pribadi mereka. Pada waktu itu ia mecoba menyelidiki secara mendalam dinamika kepribadian 
pasiennya, ia mengatakan bahwa hubungan yang dilihatnya antara kepribadian pasiennya dengan lingkungan mereka ada kemungkinan terdapat juga pada orang lain yang mempunyai masalah yang serupa. Freud menerbitkan hasil wawancaranya dengan para pasien itu serta interpretasinya tentang apa yang mereka pikirkan, impian dan tindakan mereka, dengan asumsi bahwa dari studi kasus ini akan dibuat generalisasi yang jauh jangkauannya.

Studi kasus dapat menghasilkan generalisasi yang sah (valid) dengan sangat terbatas. Oleh karena itu, kegunaan utamanya adalah bukan sebagai alat untuk menguji hipotesis, melainkan untuk menghasilkan hipotesis yang kemudian dapat diuji melalui penelitian yang lebih kokoh. Misalnya, wawasan yang diperoleh dari Piaget dalam studi kasusnya yang terkenal tentang kematanganintelektual telah menghasilkan hipotesis-hipotesis yang bagus yang telah diteliti melalui metode-metode lain sejak saat itu.

\section{3) Studi korelasi}

Fokus desain ini adalah pengukuran terhadap besarnya hubungan antara variabel-variabel. Disebut desain korelasional karena dalam pelaksanaannya menggunakan teknik analisis statistik korelasi. Peneliti memastikan sejauh mana perbedaan di salah satu variabel ada hubungannya dengan perbedaan dalam variabel yang lain. Misalnya, untuk menguji hipotesis tentang hubungan antara matematika dengan ilmu kimia, peneliti mengumpulkan nilai mata pelajaran matematika dan nilai mata pelajaran kimia bagi sampel siswa kelas tiga SMA dan kemudian menghitung koefisien korelasi antara kedua perangkat skor tersebut. Koefisien korelasi tersebut menggambarkan tingkat hubungan antar-variabel yang diselidiki. Koefisien korelasi yang mendekati angka 1 ditafsirkan sebagai korelasi yang sangat kuat. Sedangkan koefisien korelasi yang mendekati angka nol ditafsirkan sebagai korelasi yang tidak kuat (lemah), dan angka korelasi sama dengan nol $(=0)$ ditafsirkan sebagai tidak ada Korelasi. Selain itu, ada dikenal juga korelasi positif dan negatif. Korelasi positif terjadi bila penyebaran skor pada satu variabel diikuti secara konsisten oleh penyebaran skor pada variabel lain dengan arah yang sama, yaitu skor yang tinggi pada satu variabel diikuti pula oleh skor skor tinggi pada variabel lain. Sedangkan korelasi negatif terjadi bila arah penyebaran skor kedua variabel berlawanan arah.

Teknik korelasi dapat digunakan dalam penelitian yang bertujuan untuk mengusulkan hipotesis ataupun dalam penelitian yang bertujuan untuk menguji hipotesis. Misalnya, Dalam studi yang bertujuan menghasilkan hipotesis, peneliti mengukur sejumlah variabel kemudian menghitung 
koefisien korelasi antara variabel-variabel itu untuk melihat variabel-variabel mana yang tampaknya saling berkaitan. Tujuannya adalah untuk eksplorasi, bukan untuk menguji teori. Dalam studi yang bertujuan untuk menguji hipotesis, secara apriori peneliti berharap dapat mengamati adanya korelasi antara dua variabel. Pilihan variabel yang akan diteliti didasarkan pada teori yang sudah dikembangkan sebelumnya, dan peneliti tersebut juga dapat membuat hipotesis tentang arah hubungan hubungan-hubungan itu. Misalnya, dari teori fenomenologi ada hubungan antara persepsi diri siswa kelas satu dengan prestasi membaca mereka.

Langkah-langkah yang ditempuh untuk studi korelasi secara dirinci dijelaskan sebagai berikut:

\section{a) Penentuan Masalah}

Masalah yang dipilih harus mempunyai nilai yang berarti dalam pola prilaku fenomena yang kompleks dan memerlukan pemahaman. Variabel yang dimasukkan didasarkan pada pertimbangan, baik secara teoritis maupun nalar, bahwa variabel tersebut mempunyai hubungan tertentu.

b) Penentuan Subyek

Subyek yang dilibatkan harus relatif homogen dalam faktorfaktor di luar variabel yang diteliti yang mungkin dapat mempengaruhi variabel terikat. Pada umumnya, studi korelasi memerlukan sampel yang besar. Dapat diasumsikan bahwa kalau hubungan itu memang ada, hubungan itu tampak jelas dalam sampel berukuran 50 sampai 100. Jika kita ingi membuat dugaan mengenai hubungan yang ada dalam suatu populasi, maka sampel yang dipilih itu harus benar-benar mewakili populasi tersebut. Perlu diingat bahwa keragaman skor yang akan dikorelasikan memmpengaruhi besarnya koefisien korelasi. Rentangan skor yang sempit pada salah satu variabel atauun kedua-duanya akan menghasilkan koefisien korelasi yang lebih kecil daripada yang akan diperoleh seandainya rentangan skor kedua variabel itu besar.

\section{c) Pengumpulan Data}

Berbagai jenis instrumen dapat digunakan untuk mengukur dan mengumpulkan data masing-masing variabel, seperti angket, tes, pedoman interview, dan pedoman informasi. Datadata yang dikumpulkan dengan instrumen-instrumen itu harus dalam bentuk angka. 
Studi korelasi dapat dibedakan berdasarkan arah hubungannya menjadi 2, yaitu: prediktif (satu arah, dapat ditentukan variabel mana yang datang lebih dulu), dan relasional (dua arah, tidak dapat ditentukan variabel mana yang datang lebih dulu). Studi korelasi prediktif memfokuskan pada pengukuran terhadap satu variabel atau lebih yang dapat dipakai untuk memprediksi atau meramal kejadian di masa yang akan datang atau variabel lain. Studi ini melibatkan penghitungan korelasi antara variabel yang menjadi sasaran prediksi atau yang diramalkan kejadiannya (disebut kriteria), dan variabel yang dipakai untuk memprediksi (prediktor). Kedua variabel diukur dalam waktu yang berurutan, yakni variabel prediktor diukur sebelum variabel kriteria terjadi, dan tidak dapat sebaliknya. Sedangkan studi relasional hanya menyelidiki apakah kedua variabel mempunyai hubungan, tanpa mempunyai anggapan bahwa variabel yang satu muncul lebih awal dari yang lain. Oleh karena itu, kedua variabel diukur dalam waktu yang bersamaan. Selain studi korelasi prediktif dan relasional, ada studi korelasional berbentuk multivariat. Teknik korelasi multivariat mengukur dan menyelidiki tingkat hubungan antar kombinasi tiga variabel atau lebih.

\section{Contoh Penelitian Deskriptif}

Penelitian (Wahyuni, 2017) dengan judul IDENTIFIKASI GAYA BELAJAR (VISUAL, AUDITORIAL, KINESTIK) MAHASISWA PENDIDIKAN MATEMATIKA UNIVERSITAS BUNG HATTA.

Penelitian ini bertujuan untuk mengidentifikasi gaya belajar VAK mahasiswa Program Studi Pendidikan Matematika Universitas Bung Hatta. Penelitian ini termasuk dalam penelitian deskriptif. Popuasi yang diambil dalam penelitian ini adalah seluruh mahasiswa Program Studi Pendidikan Matematika angkatan 2012-2015. Teknik pangambilan sampel menggunakan teknik Purposive sampling. Instrumen yang digunakan dalam penelitian ini berupa angket/kuesioner. Hasil analisis menunjukkan bahwa mahasiswa program studi pendidikan matematika memiliki gaya belajar yang bervariasi yaitu Visual, Auditorial, dan Kinestetik. Identifikasi gaya belajar mahasiswa program studi pendidikan matematika angkatan 2012 didominasi oleh gaya belajar Auditorial 50\%, mahasiswa angkatan 2013 didominasi oleh gaya belajar Auditorial 45\%, mahasiswa angkatan 2014 didominasi oleh gaya belajar Auditorial 50\% dan mahasiswa angkatan 2015 didominasi oleh gaya belajar Visual 50\%.

\section{KASUS}

Petunjuk:

Mahasiswa mempelajari karakteristik dari jenis-jenis penelitian yang termasuk kedalam penelitian deskriptif, langkah-langkah serta desain penelitian. Selanjutnya perhatikan masalah penelitian berikut ini: 
Seorang peneliti ingin mengetahui seberapa jauh hubungan antara skor tes SPMB dengan Indeks Prestasi Kumulatif yang diperoleh oleh mahasiswa prodi Pendidikan Matematika STKIP Gotong Royong Masohi.

Pertanyaannya:

1. Jenis penelitian apakah yang diperlukan?

2. Jenis data/informasi apakah yang diperlukan?

3. Jenis instrumen apakah yang tepat digunakan?

4. Apakah sumber data lapangan yang diperlukan dan dokumendokumen penting yang diperlukan?

5. Sebutkan langkah pengolahan data dan analisis data yang tepat digunakan?

6. Rumuskan kesimpulan yang mungkin dapat ditarik dari hasil penelitian tersebut?

7. Gambarkan desain penelitiannya yang menggambarkan hubungan antar variabel?

\section{DESAIN PENELITIAN DAN PENGEMBANGAN (RESEARCH and DEVELOPMENT)}

Penelitian Pengembangan (Research and Development) adalah proses yang digunakan untuk mengembangkan dan memvalidasi produk pendidikan. Langkah-langkah proses penelitian dan pengembangan menunjukan suatu siklus, yang diawali dengan adanya kebutuhan, permasalahan yang membutuhkan pemecahan dengan menggunakan suatu produk tertentu.

Secara konseptual, desain penelitian dan pengembangan memiliki ciri berikut seperti yangdiuraikan (Bennett et al., 1984) yaitu:

1) Studying research findings, mempelajari temuan penelitian yang berkaitan dengan produk yang akan dikembangkan.

2) Developing the product, mengembangkan produk berdasarkan temuan penelitian tersebut.

3) Field testing, melakukan uji lapangan dalam setting atau situasi sebenarnya dimana produk akan digunakan.

4) Revising it, merevisi produk untuk memperbaiki kelemahankelemahan yang ditemui dalam pengujian.

Dengan demikian penelitian pengembangan merupakan suatu pengkajian sistematik terhadap pendesainan, pengembangan dan evaluasi program, proses dan produk pembelajaran yang harus memenuhi kriteria validitas, kepraktisan dan efektivitas. Produk penelitian dan pengembangan dalam bidang pendidikan dapat berupa: model, media, peralatan, buku, modul, alat evaluasi dan perangkat pembelajaran; kurikulum, kebijakan sekolah dll. 
Mengajar merupakan tugas utama seorang pendidik (guru, dosen, tutor, instruktur, widyaiswara). Pendidik yang kreatif akan selalu menciptakan ideide dalam merancang sistem pembelajaran baru yang mampu membuat siswa dapat mencapai tujuan belajarnya dengan penuh rasa puas. Untuk memperoleh sistem pembelajaran baru tersebut diperlukan metode penelitian dan pengembangan sistem pembelajaran. Metode pengembangan sistem pembelajaran tidak jauh berbeda dengan metode pengembangan produk lainnya. Prosedur pengembangan lebih singkat karena produk yang dihasilkan tidak terlalu beresiko dan dampak sistem terbatas pada siswa yang menjadi sasaran.

Tahap penelitian dan pengembangan sistem pembelajaran dapat dianalisis dari serangkaian tugas pendidik dalam menjalankan tugas pokoknya yaitu mulai dari merancang, melaksanakan sampai dengan mengevaluasi pembelajaran. Sistem pembelajaran yang dikembangkan bermakna luas, karena sistem terdiri dari komponen input, proses dan output. Komponen input pembelajaran terdiri dari karakteristik siswa, karakteristik guru, dan sarana prasarana dan perangkat pendukung pembelajaran. Komponen proses menitikberatkan pada strategi, model, dan metode pembelajaran. Komponen output berupa hasil dan dampak pembelajaran. Model penelitian dan pengembangan sistem pembelajaran dapat memilih salah satu dari komponen sistem namun dalam penerapannya harus mempertimbangkan komponen sistem yang lain.

Dalam kajian ini dipaparkan dua model penelitian dan pengembangan sistem pembelajaran yaitu model 4D dan model ADDIE. Model 4D merupakan singkatan dari Define, Design, Development and Dissemination yang dikembangkan oleh Thiagarajan (1974). Model ADDIE merupakan singkatan dari Analysis, Design, Development or Production, Implementation or Delivery and Evaluations yang dikembangkan oleh (Dick dan Carey, 1996).

Meskipun nama dan istilah yang digunakan berbeda namun model 4D dan ADDIE memiliki inti kegiatan yang sama. Beberapa kesamaan kegiatan dalam dua model tersebut misalnya: define memiliki kesetaraan kegiatan dengan analisis. Dua tahap kegiatan berikutnya yaitu design dan development dimiliki oleh kedua model tersebut. Perbedaan terletak setelah kegiatan development yaitu model 4D mengakhiri kegiatan melalui kegiatan dissemination sedangkan model ADDIE, setelah development masih dilanjutkan dengan kegiatan implementasi dan evaluasi. Model 4D tidak mencantumkan implementasi dan evaluasi karena menurut pertimbangan rasional mereka, 
proses development selalu menyertakan kegiatan pembuatan produk (implementasi), evaluasi dan revisi.

Dalam perkembangan lebih lanjut, penelitian dan pengembangan model 4D dan ADDIE juga sering digunakan dalam penelitian dan pengembangan bahan ajar seperti modul, LKS (LKPD) dan buku ajar. Tidak terbatas pada itu saja, penelitidapat menggunakan model ini untuk mengembangkan produk lain, karena pada prinsipnya inti dari prosedur pengembangan produk sudah terwakili di sini. Peneliti perlu memahami bahwa proses pengembangan memerlukan beberapa kali pengujian dan revisi sehingga meskipun prosedur pengembangan dipersingkat namun di dalamnya sudah mencakup proses pengujian dan revisi sehingga produk yang dikembangkan telah memenuhi kriteria produk yang baik, teruji secara empirisdan tidak ada kesalahankesalahan lagi.

\section{1) Model $4 \mathrm{D}$}

Model pengembangan perangkat pada jenis pengembangan Model 4-D terdiri dari 4 tahap yaitu, Define (pendefinisian), Design (perancangan), Develop (pengembangan) dan Dessiminate (penyebaran).

Kegiatan-kegiatan yang dilakukan pada setiap tahap pengembangan dapat dijelaskan sebagai berikut:

\section{a) Define (Pendefinisian)}

Kegiatan pada tahap ini dilakukan untuk menetapkan dan mendefinisikan syarat-syarat pengembangan. Dalam model lain, tahap ini sering dinamakan analisis kebutuhan. Tiap-tiap produk tentu membutuhkan analisis yang berbeda-beda. Secara umum, dalam pendefinisian ini dilakukan kegiatan analisis kebutuhan pengembangan, syarat-syarat pengembangan produk yang sesuai dengan kebutuhan pengguna serta model penelitian dan pengembangan (model $R \& D$ ) yang cocok digunakan untuk mengembangkan produk. Analisis bisa dilakukan melalui studi literature atau penelitian pendahuluan. Thiagrajan (1974) menganalisis 5 kegiatan yang dilakukan pada tahap define yaitu:

1) Front and analysis (analisis awal-akhir)

Pada tahap ini, guru melakukan diagnosis awal untuk meningkatkan efisiensi dan efektivitas pembelajaran.

2) Learner analysis (analisis siswa)

Pada tahap ini dipelajari karakteristik siswa, misalnya: kemampuan, motivasi belajar, latar belakang pengalaman, dll.

3) Task analysis (analisis tugas)

Guru menganalisis tugas-tugas pokok yang harus dikuasai siswaagar siswa dapat mencapai kompetensi minimal. 
4) Concept analysis (analisis konsep)

Menganalisis konsep yang akan diajarkan, menyusun langkahlangkah yang akan dilakukan secara rasional.

5) Specifying instructional objectives (spesifikasi tujuan pembelajaran)

Menulis tujuan pembelajaran, perubahan perilaku yang diharapkan setelah belajar dengan kata kerja operasional.

Dalam konteks pengembangan bahan ajar (modul, buku, LKS), tahap pendefinisian dilakukan dengan cara:

1) Analisis kurikulum

Pada tahap awal, peneliti perlu mengkaji kurikulum yang berlaku pada saat itu. Dalam kurikulum terdapat kompetensi yang ingin dicapai. Analisis kurikulum berguna untuk menetapkan pada kompetensi yang mana bahan ajar tersebut akan dikembangkan. Hal ini dilakukan kare-na ada kemungkinan tidak semua kompetensi yang ada dalam kurikulum dapat disediakan bahan ajarnya.

2) Analisis karakteristik siswa

Seperti layaknya seorang guru akan mengajar, guru harus mengenali karakteristik siswa yang akan menggunakan bahan ajar. Hal ini penting karena semua proses pembelajaran harus disesuaikan dengan karakteristik siswa. Hal-hal yang perlu dipertimbangkan untuk mengetahui karakteristik siswa antara lain: kemampuan akademik individu, karakteristik fisik, kemampuan kerja kelompok, motivasi belajar, latar belakang ekonomi dan sosial, pengalaman belajar sebelumnya, dsb. Dalam kaitannya dengan pengembangan bahan ajar, karakteristik siswa perlu diketahui untuk menyusun bahan ajar yang sesuai dengan kemampuan akademiknya, misalnya: apabila tingkat pendidikan siswa masih rendah, maka penulisan bahan ajar harus menggunakan bahasa dan kata-kata sederhanayang mudah dipahami. Apabila minat baca siswa masih rendah maka bahan ajar perlu ditambah dengan ilustasi gambar yang menarik supaya siswa termotivasi untuk membacanya.

3) Analisis materi

Analisis materi dilakukan dengan cara mengidentifikasi materi utama yang perlu diajarkan, mengumpulkan dan memilih materi yang relevan, dan menyusunnya kembali secara sistematis. 
4) Merumuskan tujuan

Sebelum menulis bahan ajar, tujuan pembelajaran dan kompetensiyang hendak diajarkkan perlu dirumuskan terlebih dahulu. Hal ini berguna untuk membatasi peneliti supaya tidak menyimpang dari tujuan semula pada saat mereka sedang menulis bahan ajar.

\section{b) Design (Perancangan)}

Thiagarajan membagi tahap design dalam empatkegiatan, yaitu: constructing criterion-referenced test, media selection, format selection, initial design. Kegiatan yang dilakukan pada tahap tersebut antara lain:

1) Menyusun tes kriteria, sebagai tindakan pertama untuk mengetahui kemampuan awal siswa, dan sebagai alat evaluasi setelah implementasi kegiatan.

2) Memilih media pembelajaran yang sesuai dengan materi dan karakteristik siswa.

3) Pemilihan bentuk penyajian pembelajaran disesuaikan dengan media pembelajaran yang digunakan. Bila guru akan menggunakan media audio visual, pada saat pembelajaran tentu saja siswa disuruh melihat dan mengapresiasi tayangan media audio visual tersebut.

4) Mensimulasikan penyajian materi dengan media dan langkahlangkah pembelajaran yang telah dirancang. Pada saat simulasi pembelajaran berlangsung, dilaksanakan juga penilaian dari teman sejawat.

Dalam tahap perancangan, peneliti sudah membuat produk awal (prototype) atau rancangan produk. Pada konteks pengembangan bahan ajar, tahap ini dilakukan untuk membuat modul atau buku ajar sesuai dengan kerangka isi hasil analisis kurikulum dan materi. Dalam konteks pengembangan model pembelajaran, tahap ini diisi dengan kegiatan menyiapkan kerangka konseptual model dan perangkat pembelajaran (materi, media, alat evaluasi) dan mensimulasikan penggunaan model dan perangkat pembelajaran tersebut dalam lingkup kecil.

Sebelum rancangan (design) produk dilanjutkan ke tahap berikutnya, maka rancangan produk (model, buku ajar, dll) tersebut perlu divalidasi. Validasi rancangan produk dilakukan oleh teman sejawat seperti dosen atau guru dari bidang studi/bidang keahlianyang sama. Berdasarkan hasil validasi teman sejawat tersebut, ada kemungkinan rancangan produk masih perlu diperbaiki sesuai dengan saran validator. 


\section{c) Develop (Pengembangan)}

Thiagarajan membagi tahap pengembangandalam dua kegiatan yaitu: expert appraisal dan developmental testing. Expert appraisal merupakan teknik untuk memvalidasi atau menilai kelayakan rancangan produk. Dalam kegiatan ini dilakukan evaluasi oleh ahli dalam bidangnya. Saran-saran yang diberikan digunakan untuk memperbaiki materi dan rancangan pembelajaran yang telah disusun. Developmental testing merupakan kegiatan uji coba rancangan produk pada sasaran subjek yang sesungguhnya. Pada saat uji coba ini dicari data respon, reaksi atau komentar dari sasaran pengguna model. Hasil uji coba digunakan memperbaiki produk. Setelah produk diperbaiki kemudian diujikan kembali sampai memperoleh hasil yang efektif.

Dalam konteks pengembanganbahan ajar (buku atau modul), tahap pengembangan dilakukan dengan cara menguji isi dan keterbacaan modul atau buku ajar tersebut kepada pakar yang terlibat pada saat validasi rancangan dan siswa yang akan menggunakan modul atau buku ajar tersebut. Hasil pengujian kemudian digunakan untuk revisi sehingga modul atau buku ajar tersebut benar-benar telah memenuhi kebutuhan pengguna. Untuk mengetahui efektivitas modul atau buku ajar tersebut dalam meningkatkan hasil belajar, kegiatan dilanjutkan dengan memberi soal-soal latihan yang materinya diambil dari modul atau buku ajar yang dikembangkan.

Dalam konteks pengembangan model pembelajaran, kegiatan pengembangan (develop) dilakukan dengan langkah-langkah sebagai berikut:

1) Validasi model oleh ahli/pakar. Hal-hal yang divalidasi meliputi panduan penggunaan model dan perangkat model pembelajaran. Tim ahli yang dilibatkan dalam proses validasi terdiri dari: pakar teknologi pembelajaran, pakar bidang studi pada mata pelajaran yang sama, pakar evaluasi hasil belajar.

2) Revisi model berdasarkan masukan dari para pakar pada saat validasi.

3) Ujicoba terbatas dalam pembelajaran di kelas, sesuai situasi nyata yang akan dihadapi.

4) Revisi model berdasarkan hasil uji coba.

5) Implementasi model pada wilayah yang lebih luas. Selama proses implementasi tersebut, diuji efektivitas model dan perangkat model yang dikembangkan. Pengujian efektivitas dapat dilakukan dengan eksperimen. Cara pengujian melalui eksperimen dilakukan dengan membandingkan hasil belajar pada kelompok pengguna model dan kelompok yang tidak menggunakan model. Apabila hasil belajar 
kelompok pengguna model lebih bagus dari kelompok yang tidak menggunakan model maka dapat dinyatakan model tersebut efektif.

\section{d) Disseminate (Penyebaran)}

Thiagarajan membagi tahap dissemination dalam tiga kegiatan yaitu: validation testing, packaging, diffusion and adoption. Pada tahap validation testing, produk yang sudah direvisi pada tahap pengembangan kemudian diimplementasikan pada sasaran yang sesungguhnya. Pada saat implementasi dilakukan pengukuran ketercapaian tujuan. Pengukuran ini dilakukan untuk mengetahui efektivitas produk yang dikembangkan. Setelah produk diimplementasikan, pengembang perlu melihat hasil pencapaian tujuan. Tujuan yang belum dapat tercapai perlu dijelaskan solusinya sehingga tidak terulang kesalahan yang sama setelah produk disebarluaskan. Kegiatan terakhir dari tahap pengembangan adalah melakukan packaging (pengemasan), diffusion and adoption. Tahap ini dilakukan supaya produk dapat dimanfaatkan oleh orang lain. Pengemasan model pembelajaran dapat dilakukan dengan mencetak buku panduan penerapan model pembelajaran. Setelah buku dicetak, buku tersebut disebarluaskan supaya dapat diserap (diffusi) atau dipahami orang lain dan digunakan (diadopsi) pada kelas mereka.

Pada konteks pengembangan bahan ajar, tahap dissemination dilakukan dengan cara sosialisasi bahan ajar melalui pendistribusian dalam jumlah terbatas kepada guru dan siswa. Pendistribusian ini dimaksudkan untuk memperoleh respons, umpan balik terhadap bahan ajar yang telah dikembangkan. Apabila respon sasaran pengguna bahan ajar sudah baik maka baru dilakukan pencetakan dalam jumlah banyak dan pemasaran supaya bahan ajar itu digunakan oleh sasaran yang lebih luas. Tahap pengembangan Model 4-D dapat dilihat pada gambar dibawah 6.1.

2) Model ADDIE

ADDIE merupakan singkatan dari Analysis, Design, Development or Production, Implementation or Delivery and Evaluations. Menurut langkahlangkah pengembangan produk, model penelitian dan pengembangan ini lebih rasional dan lebih lengkap daripada model 4D. Inti kegiatan pada setiap tahap pengembangan juga hampir sama. Oleh sebab itu, model ini dapat digunakan untuk berbagai macam bentuk pengembangan produk seperti model, strategi pembelajaran, metode pembelajaran, media dan bahan ajar. 


\section{DEFINE}
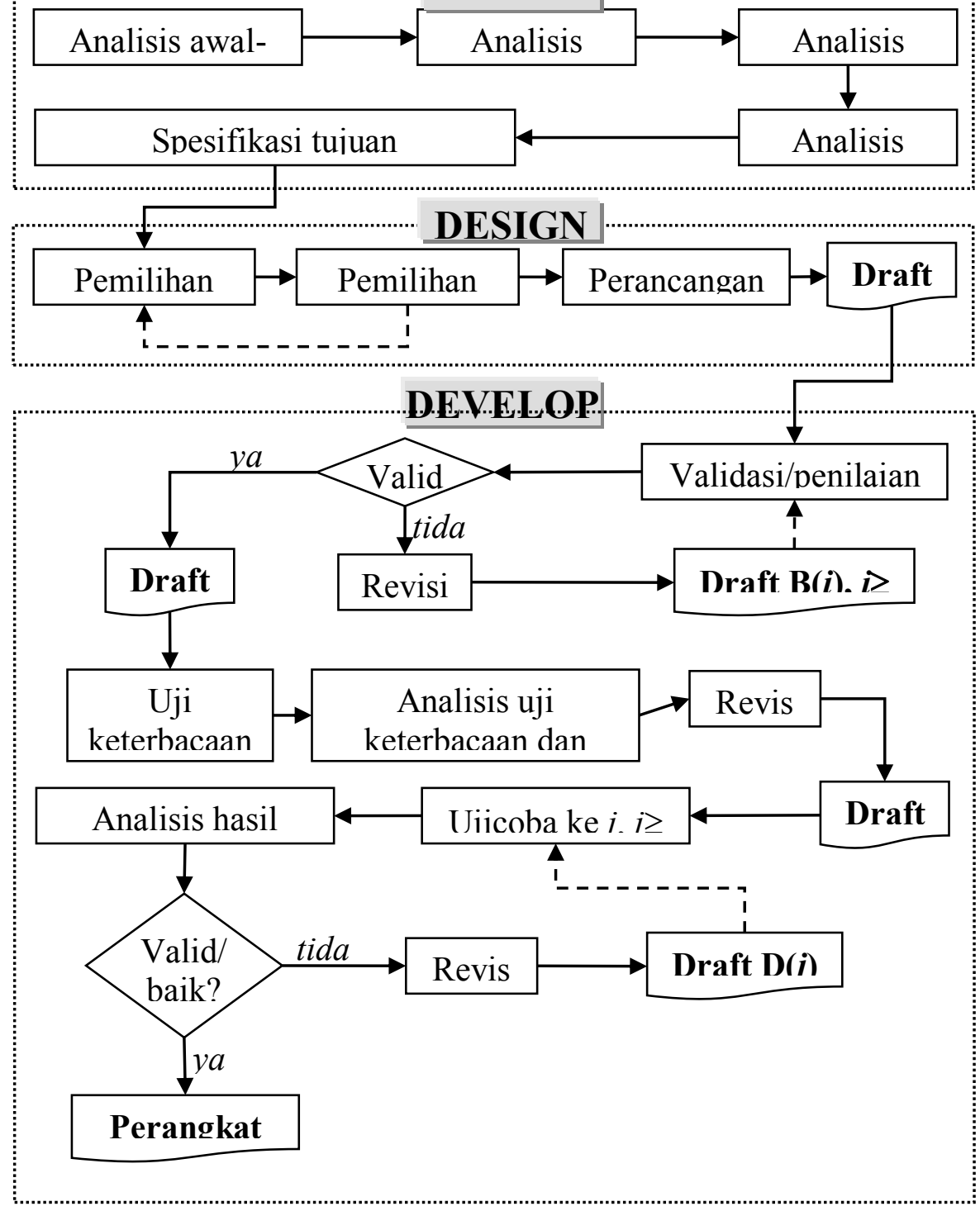

Keterangan

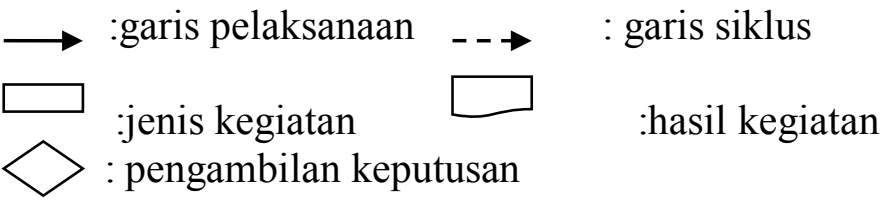


Model ADDIE dikembangkan oleh untuk merancang sistem pembelajaran. Berikut ini diberikan contoh kegiatan pada setiap tahap pengembangan model atau metode pembelajaran, yaitu:

\section{a) Analysis}

Pada tahap ini, kegiatan utama adalah menganalisis perlunya pengembangan model/metode pembelajaran baru dan menganalisis kelayakan dan syarat-syarat pengembangan model/metode pembelajaran baru. Pengembangan metode pembelajaran baru diawali oleh adanya masalah dalam model/metode pembelajaran yang sudah diterapkan. Masalah dapat terjadi karena model/metode pembelajaran yang ada sekarang sudah tidak relevan dengan kebutuhan sasaran, lingkungan belajar, teknologi, karakteristik siswa.

Setelah analisis masalah perlunya pengembangan model/metode pembelajaran baru, peneliti juga perlu menganalisis kelayakan dan syaratsyarat pengembangan model/metode pembelajaran baru tersebut. Proses analisis misalnya dilakukan dengan menjawab beberapa pertanyaan berikut ini: (1) apakah model/metode baru mampu mengatasi masalah pembelajaran yang dihadapi, (2) apakah model/metode baru mendapat dukungan fasilitas untuk diterapkan; (3) apakah dosen atau guru mampu menerapkan model/metode pembelajaran baru tersebut Dalam analisis ini, jangan sampai terjadi ada rancangan model/metode yang bagus tetapi tidak dapat diterapkan karena beberapa keterbatasan misalnya saja tidak ada alat atau guru tidak mampu untuk melaksanakannya. Analisis metode pembelajaran baru perlu dilakukan untuk mengetahui kelayakan apabila metode pembelajaran tersebut diterapkan.

\section{b) Design}

Dalam perancangan model/metode pembelajaran, tahap desain memiliki kemiripan dengan merancang kegiatan belajarmengajar. Kegiatan ini merupakan proses sistematik yang dimulai dari menetapkan tujuan belajar, merancang skenario atau kegiatan belajar mengajar, merancang perangkat pembelajaran, merancang materi pembelajaran dan alat evaluasi hasil belajar. Rancangan model/metode pembelajaran ini masih bersifat konseptual dan akan mendasari proses pengembangan berikutnya.

\section{c) Development or Production}

Development dalam model ADDIE berisi kegiatan realisasi rancangan produk. Dalam tahap desain, telah disusun kerangka konseptual penerapan model/metode pembelajaran baru. Dalam tahap pengembangan, kerangka yang masih konseptual tersebut direalisasikan menjadi produk yang siap diimplementasikan. Sebagai contoh, apabila pada tahap design telah dirancang 
penggunaan model/metode baru yang masih konseptual, maka pada tahap pengembangan disiapkan atau dibuat perangkat pembelajaran dengan model/metode baru tersebut seperti RPP, media dan materi pelajaran.

\section{d) Implementation or Delivery}

Pada tahap ini diimplementasikan rancangan dan metode yang telah dikembangkan pada situasi yang nyata yaitu di kelas. Selama implementasi, rancangan model/metode yang telah dikembangkan diterapkan pada kondisi yang sebenarnya. Materi disampaikan sesuai dengan model/metode baru yang dikembangkan. Setelah penerapan metode kemudian dilakukan evaluasi awal untuk memberi umpan balik pada penerapan model/metode berikutnya.

\section{e) Evaluations}

Evaluasi dilakukan dalam dua bentuk yaitu evaluasiformatif dan sumatif. Evaluation formatif dilaksanakan pada setiap akhir tatap muka (mingguan) sedangkan evaluasi sumatif dilakukan setelah kegiatan berakhir secara keseluruhan (semester). Evaluasi sumatif mengukur kompetensi akhir darimata pelajaran atau tujuan pembelajaran yang ingin dicapai. Hasil evaluasi digunakan untuk memberi umpan balik kepada pihak pengguna model/metode. Revisi dibuat sesuai dengan hasil evaluasi atau kebutuhan yang belum dapat dipenuhi oleh model/metode baru tersebut.

Berikut ini ilustrasi gambar Model ADDIE yang disadur penulis dari (Branch, 2009)

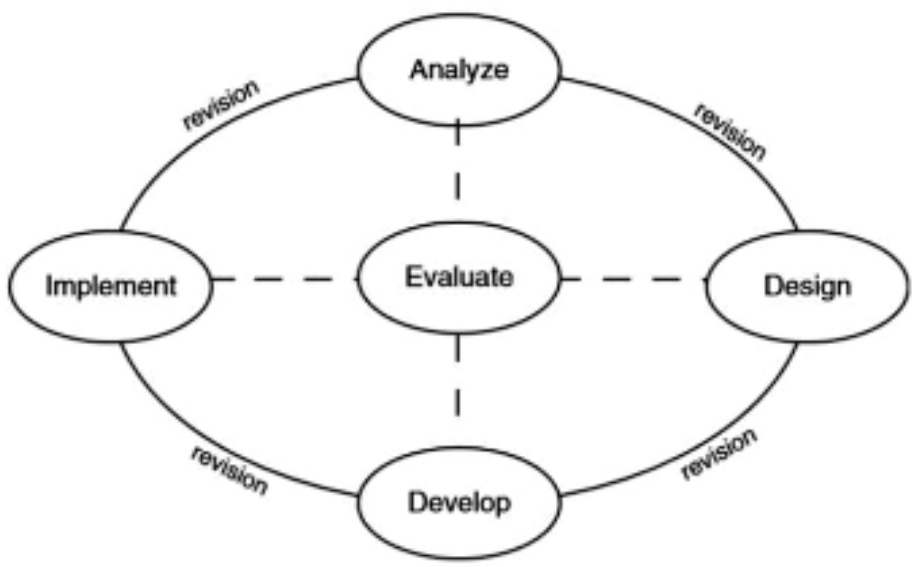

Gambar 6.2. Tahap pengembangan Model ADDIE 
Tabel 6.2. Rangkuman aktivitas Model ADDIE

\begin{tabular}{|c|c|}
\hline Tahap Pengembangan & Aktivitas \\
\hline Analysis & $\begin{array}{l}\text { Pra perencanaan: pemikiran tentang produk } \\
\text { (model, metode, media, bahan ajar) baru yang akan } \\
\text { dikembangkan. Mengidentifikasi produk yang } \\
\text { sesuai dengan sasaran siswa, tujuan belajar, } \\
\text { mengidentifikasi isi/materi pembelajaran, } \\
\text { mengidentifikasi lingkungan belajar dan strategi } \\
\text { penyampaian dalam pembelajaran. }\end{array}$ \\
\hline Design & $\begin{array}{l}\text { Merancang konsep produk baru di atas kertas. } \\
\text { Merancang perangkat pengembanganproduk baru. } \\
\text { Rancangan ditulis untuk masing-masing unit } \\
\text { pembelajaran. Petunjuk penerapan desain atau } \\
\text { pembuatan produk ditulis secara rinci. }\end{array}$ \\
\hline Develop & $\begin{array}{l}\text { Mengembangkan perangkat produk (materi/bahan } \\
\text { dan alat) yang diperlukan dalam pengembangan. } \\
\text { Berbasis pada hasil rancangan produk, pada tahap } \\
\text { ini mulai dibuat produknya (materi/bahan, alat) } \\
\text { yang sesuai dengan struktur model. Membuat } \\
\text { instrumen untuk mengukur kinerja produk. }\end{array}$ \\
\hline Implementation & $\begin{array}{l}\text { Memulai menggunakan produk baru dalam } \\
\text { pembelajaran atau lingkungan yang nyata. } \\
\text { Melihat kembali tujuan-tujuan pengembangan } \\
\text { produk, interaksi antar siswaserta menanyakan } \\
\text { umpan balik awal proses evaluasi. }\end{array}$ \\
\hline Evaluation & $\begin{array}{l}\text { Melihat kembali dampak pembelajaran dengan cara } \\
\text { yang kritis. Mengukur ketercapaian tujuan } \\
\text { pengembangan produk. Mengukur apa yang telah } \\
\text { mampu dicapai oleh sasaranMencari informasi apa } \\
\text { saja yang dapat membuat siswamencapai hasil } \\
\text { dengan baik. }\end{array}$ \\
\hline
\end{tabular}

(Mulyatiningsih, 2011)

Model R\&D yang telah dipaparkan pada bagian ini memberi gambaran bahwa model R\&D memiliki tujuan yang sama yaitu menghasilkan sebuah produk yang teruji secara empiris. Untuk menghasilkan produk tersebut, maka perlu ada tahapan kegiatan yang terdokumentasi dan terukur pada semua tahap pengembangan. 
Model R\&D membutuhkan waktu yang relatif panjang. Peneliti sering membagi kegiatan penelitian dalam beberapa tahap. Pada umumnya, kegiatan penelitian tahun pertama dirancang untuk mengidentifikasi masalah dan merancang produk. Pada tahun berikutnya, kegiatan penelitian dilakukan untuk mengimplementasikan rancangan produk pada pengguna. Proses penelitian yang panjang tersebut tentu saja membutuhkan berbagai jenis data, sumber data dan metode analisi data yang berbeda-beda. Peneliti dituntut mampu mengaplikasikan pengetahuan dasar tentang metode penelitian untuk dapat mengatasi masalah pada saat proses pengembangan berlangsung.

3) Sistematika laporan penelitian dan pengembangan (Research and Development)

\section{HALAMAN JUDUL}

\section{ABSTRAK}

PENGANTAR

\section{DAFTAR ISI}

\section{DAFTAR GAMBAR}

\section{DAFTAR TABEL}

\section{BAB I. PENDAHULUAN}
A. Latar Belakang Masalah
B. Rumusan Masalah
C. Tujuan Peneltian
D. Spesifikasi Produk yang Dikembangkan
E. Manfaat Pengembangan
F. Asumsi dan Keterbatasan Pengembangan
G. Defenisi Istilah

\section{BAB II. KAJIAN PUSTAKA}
A. Kajian Teori
Kajian teori tentang produk yang dikembangkan
$>$ Kajian teori tentang model pengembangan
B. Hasil penelitian yang relevan
C. Kerangka Pemikian
D. Hipotesis (produk yang akan dihasilkan)

\section{BAB III. METODE PENELITIAN}
A. Langkah-langkah penelitian
B. Metode penelitian tahap I

1. Populasi sampel sumber data 
2. Teknik pengumpulan data

3. Intsrumen penelitian

4. Analisis data

5. Perencanaan desain produk

6. Validasi desain

C. Metode penelitian tahap II

1. Metode rancangan eksperimen untuk menguji produk yang telah dirancang

2. Populasi dan sampel

3. Teknik pengumpulan data

4. Instrumen penelitian

5. Teknik analisis data

BAB IV. HASIL PENELITIAN DAN PEMBAHASAN
A. Desain awal produk (gambar dan penjelasan)
B. Hasil pengujian pertama
C. Revisi produk (gambar setelah direvisi dan penjelasannya)
D. Hasil pengujian tahap II
E. Revisi produk (gambar setelah direvisi dan penjelasannya)
F. Pengujian tahap III (jika diperlukan)
G. Penyempurnaan produk (gambar terakhir dan penjelasannya)

H. Pembahasan produk

\section{BAB V. SIMPULAN DAN SARAN PENGGUNAAN}
a. Simpulan
b. Saran penggunaan

DAFTAR PUSTAKA

LAMPIRAN INSTRUMEN

LAMPIRAN DATA

LAMPIRAN PRODUK YANG DIHASILKAN 


\section{4) Contoh penelitian dan pengembangan (R \& D)}

Penelitian (Sohilait, 2018) tentang Pengembangan Perangkat Pembelajaran Matematika pada Materi Himpunan Melalui pendekatan Pendidikan Matematika Realistik.

Penelitiannya adalah penelitian dan pengembangan perangkat pembelajaran pada materi Himpunan melalui pendekatan Pendidikan Matematika Realistik (PMR). Tujuan dari penelitian ini adalah untuk menghasilkan perangkat pembelajaran yang valid, praktis dan efektif. Perangkat pembelajaran yang dimaksudkan dalam penelitian ini adalah: rencana pelaksanaan pembelajaran (RPP), lembar kegiatan siswa (LKS), dan tes hasil belajar (THB). Proses pengembangan perangkat pembelajaran menggunakan model 4-D berdasarkan Thiagarajan yang terdiri dari 4 fase, yaitu (1) tahap pendefinisian, (2) tahap desain, (3) tahap pengembangan, (4) tahap penyebaran, dan tahap diseminasi. Perangkat pembelajaran yang dikembangkan melalui pendekatan PMR divalidasi oleh dua ahli yang dihasilkan, dalam bentuk: rencana pelaksanaan pembelajaran (RPP), lembar kegiatan siswa (LKS), dan tes hasil belajar (THB) yang dinyatakan valid dan layak untuk diuji. Tes dilakukan untuk kelas VII.2 di SMP Negeri 2 Amahai dengan total 27 siswa. Dari hasil analisis kelayakan perangkat pembelajaran ditemukan bahwa: (1) kemampuan guru dalam mengelola pembelajaran baik, (2) aktivitas siswa dalam pembelajaran efektif, (3) respons siswa terhadap perangkat pembelajaran adalah perangkat pembelajaran hasil tes positif, (4) memenuhi kriteria valid dan dapat diandalkan, dan (5) penguasaan pembelajaran siswa selesai. Oleh karena itu, perangkat pembelajaran matematika pada materi Himpunan melalui pendekatan Pendidikan Matematika Realistik (PMR) dinyatakan valid, praktis, dan efektif.

Lanjutkan dengan mencari jurnal penelitian diberbagai bidang pendidikan dengan menggunakan model ADDIE.

\section{E. DESAIN RISET (DESIGN RESEARCH)}

\section{a) Pengertian Design Research}

Design research merupakan pendekatan penelitian desain pembelajaran dirancang untuk merumuskan solusi atas kompleksitas masalah yang muncul dalam praktik pendidikan, dimana masalah tersebut belum memiliki solusi yang tepat atau belum ada pedoman yang jelas untuk menyelesaikan masalah tersebut. Kegiatan desain pembelajaran dipandang sebagai hal yang sama dengan kegiatan pengembangan pembelajaran, meskipun dalam tataran konseptual setiap model desain atau model pengembangan pembelajaran 
memiliki kekhusuan dan penekanan tersendiri yang membedakan antara yang satu dengan yang lain.

Secara lugas, design research dipandang sebagai kajian yang sistematis yang terdiri atas kegiatan perancangan, pengembangan, dan evaluasi intervensi pendidikan yang bertujuan untuk memperbaiki atau meningkatkan kualitas kegiatan atau program pendidikan.

Secara konseptual, praktik design research dapat diklasifikasi menjadi dua orientasi, yaitu (1) design research untuk pengembangan intervensi (development studies); dan (2) design reserach untuk mengetes atau menguji teori (validation studies).

b) Karateristik Design Research

Selain ciri khasnya untuk menyelesaikan masalah praktis dalam dunia pendidikan, (Van den Akker, 2006) menyimpulkan 5 karakteristik penelitian pengembangan pendidikan pada design research, yaitu:

1 Pengembangan intervensi (Interventionist), yaitu design research bertujuan untuk merancang dan mengmbangkan intervensi pendidikan (misalnya: program, materi dan strategi pembelajaran, produk dan sistem pendidikan) dalam suasana konteks yang natural (real world setting), bukan suasana artifisial atau laboratorik yang membatasi variabel-variabel tertentu.

2 Berorientasi pada teori (Theory oriented), yaitu selain berorientasi pada pengembangan intervensi untuk menyelesaikan masalah praktis dalam dunia pendidikan, design research juga berorientasi pada merumuskan prinsip-prinsip intervensi (teori intervensi) yang mendasari efektivitas dan efisiensi serta kepraktisan intervensi tersebut dalam menyelesaikan masalah. Teori intervensi inidapat menjadi rujukan orang lain dalam menyelesaikan masalah dengan karakteristik yang serupa di tempat lain (generalisasi).

3 Proses yang berulang (iterative), yaitu pengembangan intervensi tersebut dilakukan dalam serangkaian siklus kegiatan yang dilakukan secara berulang-ulang hingga mendapatkan kualitas intervensi yang sesuai dengan harapan (practical dan theoritical). Siklus kegiatan tersebut secara umum terdiri atas kegiatan: analisis; perancangan dan pengembangan; dan evaluasi dan perbaikan. Karakteristik pengulangan ini pun dapat terjadi dalam setiap kegiatan tersebut atau antar dua kegiatan. Proses perulangan ini (Putrawangsa, 2018) digambarkan dengan baik pada gambar dibawah ini. 


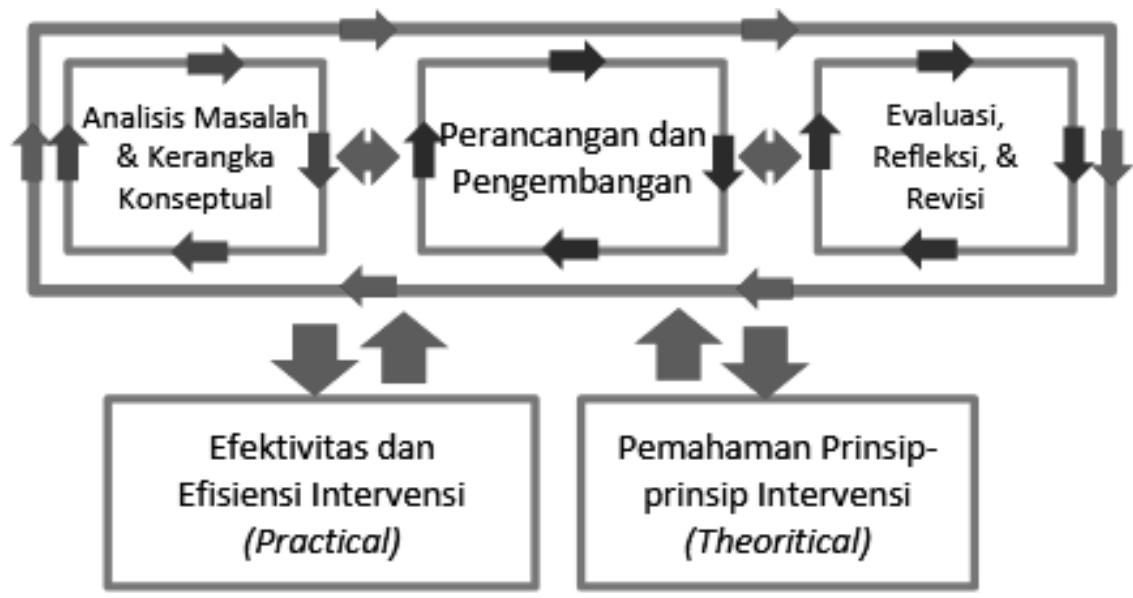

Gambar 6.3. Proses Perulangan (iterative) pada Design Research Gambar tersebut menunjukkan siklus yang bersifat pengulangan (iterative) pada pelaksanaan Design Research guna mendapatkan intervensi yang efektif dan efisien untuk menyelesaikan masalah pendidikan (practical orientations) dan mendapatkan rumusan prinsip-prinsip pada intervensi tersebut (theoritical orientation). Iterasi tidak hanya dilakukan pada siklus tiga tahapan inti Design Research, melainkan juga pada setiap tahapan, dan bahkan iterasi terjadi antar kegiatan.

4 Berorientasi pada proses (Process oriented), yaitu design research sangat menekakan pada proses memahami bagaimana intervensi bekerja dalam menyelesaikan masalah (prinsip-prinsip intervensi), dan bagaimana meningkatkan efektivitas dan efisiensi dari intervensi tersebut, bukan sekedar pada menemukan jawaban akhir apakah intervensi berhasil atau tidak berhasil dalam menyelesaikan masalah, meskipun ini juga bagian dari orientasi design research, menyelesaikan masalah pendidikan.

5 Berorientasi pada penggunaan (utility oriented), yaitu kemudahan pelaksanaan dan penggunaan intervensi dalam situasi nyata oleh pihak pengguna intervensi menjadi salah satu penekanan dalam pengembangan intervensi pada design research.

\section{c) Intervensi dan teori intervensi}

Design research tidak hanya bertujuan untuk mengembangkan intervensi untuk menyelesaikan masalah pendidikan, akan tetapi juga berorientasi pada menemukan prinsip-prinsip atau karakteristik yang bekerja pada intervensi tersebut.

Design research dalam pelaksanaanya selalu memiliki dua tujuan tersebut yang saling besinergi antara yang satu dengan yang lainnya, yang kemudian 
dikenal dengan istilah tujuan praktis dan tujuan teoritis. Tujuan praktis dari Design research adalah pengembangan intervensi, sedangkan tujuan teoritisnya adalah pengembangkan teori intervensi. Kedua tujuan ini saling berkaitan dan saling menginspirasi.

Istilah intervensi dalam hal ini merujuk pada segala hal yang dapat dirancang dan dikembangkan untuk maksud tertentu yang merupakan tujuan pengembangan intervensi tersebut. Sehingga intervensi pendidikan merujuk pada segala hal yang dapat dirancang dan dikembangkan dalam konteks pendidikan untuk mencapai tujuan pengembangan intervensi. Beberapa bentuk intervensi pendidikan antara lain: program pendidikan, sistem pendidikan, produk pendidikan, proses pembelajaran, strategi dan metode pembelajaran, kegiatan pembelajaran, kurikulum, materi pembelajaran, suasana pembelajaran, media pembelajaran, dan sebagainya yang semua itu dapat dijadikan sebagai domain/konteks kajian design research.

Untuk lebih memahami makna istilah 'intervensi' dalam design research, mari kita perhatikan permisalan berikut ini: Untuk menyelesaikan masalah miskonsepsi siswa mengenai pengukuran luas, maka perlu diadakan design research, yaitu pengembangan rangkaian kegiatan pembelajaran untuk menyelesaikan masalah miskonsepsi tersebut. Dalam hal ini, bentukintervensi dalam kegiatan design research tersebut adalah: (1) rangkaian kegiatan pembelajaran yang akan dikembangkan, termasuk didalamnya adalah (2) prinsip dan karaktersitik yang melandasi kegiatan pembelajaran tersebut serta (3) kondisi lingkungan dan norma yang menjamin keberhasilan pelaksanaan kegiatan pembelajaran tersebut.

Dengan demikian, dapat disimpulkan bahwa teori intervensi menjelaskan apa (karakteristik intervensi), bagaimana (prosedur intervensi), dan mengapa (argumentasi) suatu intervensi efketif dan efisien untuk menyelesaikan masalah yang menjadi tujuan dari pengembgangan intervensi tersebut. Untuk dapat merumuskan suatu 'teori intervensi' dari suatu intervensi kegiatan pengembangan, seorang pengembang diharuskan memiliki kemampuan untuk menganalisis, melihat dan memahami secara holistik dan integratif cara kerja setiap komponen pembangun suatu intervensi dan juga bagaimana komponen tersebut terhubung antara yang satu dengan yang lainnya dalam menyelesaikan masalah pengembangan. 


\section{d) Jenis-jenis Design Research}

Varian atau jenis-jenis design research muncul karena adalah perbedaan penekanan orientasi dari pelaksanaan design research. Jika sesorang melakukan design research dengan tujuan untuk merancang dan mengembangkan intervensi guna menyelesaikan masalah praktis pendidikan, maka design research jenis ini disebut dengan istilah development studies. Sedangkan design research yang bertujuan untuk mengembangkan atau memvalidasi teori pembelajaran, maka design research jenis ini disebut dengan istilah validation tudies. Varian terakhir adalah design research yang bertujuan untuk mengimplementasikan suatu produk guna mengetahuai kondisi dan strategi yang dibutuhkan agar program tersebut efektif, maka design research jenis ini disebut dengan istilah implementation studies.

Ketiga varian design research di atas selalu memiliki dua tujuan dalam pelaksanaanya yang saling besinergi antara yang satu dengan yang lainnya, yaitu tujuan praktis dan tujuan teoritis. Tujuan praktis dapat menginspirasi tujuan teoritis ataupun sebaliknya tujuan toritis berpotensi menginspirasi tujuan praktis. Karena keterkaitannya yang kuat ini, dua tujuan design research ini dikenal dengan istilah the two fold yield of Design Research, yaitu 'tujuan ganda' dari design research. Orientasi masing-masing varian design research dan tujuan praktis dan teoritisnya dipaparkan pada tabel dibawah ini.

Tabel 6. 3. Jenis Design Research dan Tujuan Ganda masing-masing

\begin{tabular}{|l|l|l|l|}
\hline \multirow{2}{*}{ Jenis } & \multicolumn{1}{|c|}{ Orientasi } & \multicolumn{2}{c|}{ Tujuan } \\
\cline { 3 - 4 } \begin{tabular}{l} 
Studies \\
\cline { 3 - 4 }
\end{tabular} & $\begin{array}{l}\text { Mengembangkan } \\
\text { Intervensi }\end{array}$ & $\begin{array}{l}\text { Teoritis } \\
\text { teori intervensi }\end{array}$ & $\begin{array}{l}\text { Mengembangkan } \\
\text { intervensi yang } \\
\text { berbasis riset } \\
\text { sebagai solusi atas } \\
\text { masalah yang } \\
\text { kompleks }\end{array}$ \\
\hline Validation Studies & $\begin{array}{l}\text { Mengembangkan } \\
\text { bahan/alat }\end{array}$ & $\begin{array}{l}\text { Mengembangkan } \\
\text { dan memvalidasi } \\
\text { teori tentang } \\
\text { pembelajaran, } \\
\text { suasana } \\
\text { pembelajaran, } \\
\text { atau untuk }\end{array}$ & $\begin{array}{l}\text { Mengembangkan } \\
\text { suasana } \\
\text { pembelajaran } \\
\text { dengan tujuan } \\
\text { tertentu }\end{array}$ \\
& & & \\
\hline
\end{tabular}




\begin{tabular}{|c|c|c|c|}
\hline & & $\begin{array}{l}\text { memvalidasi teori } \\
\text { intervensi }\end{array}$ & \\
\hline $\begin{array}{l}\text { Implementation } \\
\text { Studies }\end{array}$ & $\begin{array}{l}\text { Mengimplementas } \\
\text { i program atau } \\
\text { intervensi yang } \\
\text { sudah valid pada } \\
\text { konteks yang lebih } \\
\text { luas }\end{array}$ & $\begin{array}{l}\text { Memahami } \\
\text { strategi dan } \\
\text { kondisi yang } \\
\text { menjamin } \\
\text { keberhasilan atau } \\
\text { keterlaksanaan } \\
\text { dari program atau } \\
\text { intervensi } \\
\text { tersebut }\end{array}$ & $\begin{array}{l}\text { Mengimplementasik } \\
\text { an program atau } \\
\text { intervensi tertentu }\end{array}$ \\
\hline
\end{tabular}

(Plomp \& Nieveen, 2013)

Dengan pertimbangan kebermanfaatan dan kepraktisan, dalam buku ini pembahasan mengenai varian design research akan difokuskan pada development studies dan validation studies.

\section{a) Development Studies}

Design research jenis ini digunakan ketika pengembang memiliki orientasi untuk mengembangkan intervensi sebagai solusi atas masalah pendidikan yang kompleks atau masalah pendidikan yang belum memiliki pedoman penyelesaian atau pedoman penyelesaian yang ada terbukti tidak/kurang efektif.

Selain bertujuan untuk mengembangkan intervensi guna menyelesaikan masalah pendidikan, development studies juga bertujuan untuk merumuskan teori intervensi, yaitu rumusan heuristik yang menjelaskan bagaimana dan mengapa intervensi tersebut dinyatakan valid untuk menyelesaikan masalah yang sedang dikaji.

Pada umumnya, tahapan pengembangan dalam development studies adalah sebagai berikut:

1) Studi pendahuluan (analisis dan eksplorasi), yaitu sejumlah kegiatan yang terdiri atas analisis dan eksplorasi konteks dan kebutuhan (masalah), review literatur, dan pengembangan kerangka teoritis kegiatan desain.

2) Pengembangan Prototipe (desain dan konstruksi), yaitu kegiatan pengembangan intervensi yang masih berupa prototipe melalui kegiatan uji coba yang dilakukan secara berulang kali (iteratif). Selama proses itu, evaluasi formatif 
dilakukan sebagai dasar untuk memperbaiki kualitas intervensi (dan juga teori intervensi).

3) Tahapan penilaian (evaluasi dan refleksi), yaitu tahapan dimana evaluasi sumatif dilakukan untuk menguji intervensi dan teori intervensi, yaitu menguji apakah intervensi dan teori intervensi yang telah dikembangkan memenuhi kriteria yang diharapkan.

Langkah awal dalam development studies adalah identifikasi masalah, yaitu masalah pendidikan yang belum memiliki pedoman penyelesaian atau telah memiliki pedoman penyelesaian akan tetapi terbukti tidak atau kurang efektif, sehingga perlu diadakan kajian untuk menemukan solusi valid atas masalah tersebut.

Pengembangan intervensi dalam development studies dapat dilakukan pada tingkat sistem atau pada tingkat institusional (kelembagaan). Pada tingkat sistem, misalnya, seseorang berkeinginan untuk mengembangkan intervensi berupa pengembangan sistem pembelajaran online untuk siswa menengah atas, atau pengembangan sistem kegiatan laboratorium berbasis CAL (Computer Assist Laboratory) untuk siswa menengah pertama.

Sedangkan pada tingkat institusional, misalnya, seseorang berkeinginan untuk mengembangkan intervensi berupa identifikasi metode yang efektif untuk melakukan pembelajaran berbasis masalah pada siswa sekolah dasar. Dalam hal ini, pengembang tidak bermaksud untuk mengembangkan sistem, melainkan bertujuan untuk merumuskan metode yang efektif untuk tujuan tertentu pada tingkat kelembagaan sekolah dasar.

Pengembangan prototipe intervensi adalah salah satu karakteristik dari development studies, yaitu draf awal intervensi dirancang dengan mempertimbangkan contoh atau model intervensi lainnya yang relevan, meski pada konteks yang berbeda namun dipandang dapat memberikan inspirasi. Selain itu, kajian literatur dilakukan untuk mendapatkan basis teoritis dan argumentasi atas model intervensi yang dikembangkan. Jadi, dengan memperhatikan model intervensi lainnya dan kajian literatur yang relevan, draf intervensi awal dikembangkan (prototipe 1). Intervensi awal ini kemudian diuji coba pada target terbatas (pilot study), kemudian dievaluasi dampaknya. Hasil evaluasi dijadikan dasar untuk merevisi model intervensi awal, yang kemudian menghasilkan intervensi yang 
telah direvisi (prototipe 2). Prototipe 2 ini kemudian diujicoba kembali pada target yang lebih luas dari terget sebelumnya, kemudian dievaluasi dan direvisi sehingga menghasilkan intervensi yang telah direvisi untuk kedua kalinya, yaitu prototipe 3. Proses pengembangan prototipe ini terus berlanjut hingga prototipe tersebut dipandang "cukup efektif dan efisien" untuk menyelesaikan masalah yang menjadi bidang kajiannya.

Karena prototipe final tersebut dipandang telah menyelesaikan masalah yang menjadi atensi kegiatan pengembangan, maka dalam hal ini proses pengembangan tersebut tersebut telah mencapai tujuan pertama dari development studies, yaitu pengembangan intervensi berbasis riset untuk menyelesaikan masalah pendidikan yang kompleks.

Untuk mencapai tujuan kedua, yaitu perumusan teori intervensi atau prinsip rancangan (design principle), pengembang melakukan refleksi secara sistematis dan holistik terhadap proses pengembangan yang telah dilakukan untuk menemukan jawaban atas pertanyaan bagaimana dan mengapa prototipe final efektif dan efisien untuk menyelesaikan masalah yang sedang dikaji. Jawaban atas pertanyaan tersebut menghasilkan rumusan teori intervensi dari kegiatan pengembangan tersebut, yang merupakan bentuk output kedua dari development studies, yaitu perumusan teori intervensi.

Rumusan teori intervensi tersebut merupakan suatu pedoman begaimana mengimplementasikan intervensi dan mengapa intervensi tersebut dapat memberikan dampak positif terhadap pencapain tujuan. Akker (Putrawangsa, 2018) menggambarkan rumusan teori intervensi tersebut dalam suatu pernyataan heuristik berikut ini:

"If you want to design (intervention $X$ ) for the (purpose/function $Y$ ) in (context $Z$ ), then you are best advised to give (that intervention) the (characteristics $A, B$, and $C$ ) [substantive emphasis], and to do that via (procedures $K, L$, and $M$ ) [procedural emphasis], because of (arguments $P, Q$, and $R$ )".

Pernyataan di atas kurang lebih dapat diterjemahkan seperti berikut: "Jika kamu ingin merancang intervensi $\mathrm{X}$ untuk maksud/tujuan Y dalam konteks Z, maka kamu disarankan untuk memiliki intervensi dengan karakteristik A, B, dan C [penekanan substansi] dan melakukannya melalui prosedur $\mathrm{K}, \mathrm{L}$, dan $\mathrm{M}$ [penekanan prosedur], karena alasan P, Q, dan R". 
Dari pernyataan Akker (2006), dapat dibedakan dua jenis teori intervensi, yaitu:

1) Teori intervensi prosedur, yaitu karakteristik dari pendekatan yang digunakan dalam intervensi tersebut.

2) Teori intervensi substansi, yaitu karakteristik dari isi intervensi tersebut.

Rumusan teori intervensi ini akan semakin meyakinkan jika disertai dengan argumentasi teori lainnya yang relevan dan mendukung, dipaparkan dengan artikulasi yang baik sehingga dapat menjadi pedoman tindakan yang jelas, dan didasarkan dengan bukti atau data lapangan yang menunjukkan dampak dari intervensi tersebut.

\section{b) Validation Studies}

Berbeda dengan development studies (yaitu fokus pada mengembangkan intervensi yang inovatif untuk penyelesaian masalah), validation studies fokus pada pengembangan intervensi yang bertujuan untuk mengembangkan atau memvalidasi teori tentang proses pembelajaran dan bagaimana suasana pembelajaran tersebut dapat dirancang Gravemeijer \& Cobb (Plomp \& Nieveen, 2013).

Dalam istilah Cobb et al (Putrawangsa, 2018) validation studies dikenal dengan istilah design experiment (eksperimen rancangan), yaitu bertujuan untuk "to develop a class of theories about both the process of learning and the means that are designed to support thatlearning". Pernyataan di atas menegaskan bahwa validation studies bertujuan untuk mengembangkan teori baik tentang proses pembelajaran maupun perangkat yang dirancang untuk mendukung pembelajaran tersebut.

Berdasarkan pandangan Cobb et al. tentang design experiment ini, validations studies diharapkan menghasilkan pemahaman yang lebih luas lagi tentang ekologi pembelajaran, yaitu suatu sistem yangkompleksterdiri atas berbagai elemen atau faktor pada pembelajaran yang saling terhubung dan saling berinteraksi. Elemen pada ekologi pembelajaran tersebut beserta fungsinya atau pengaruhnya dikendalikan melalui proses rekayasa (desain) guna mendukung proses pembelajaran. Sebagai contoh, ketika merancang pembelajaran untuk membantu siswa memahami konsep dasar 
aljabar pada siswa berumur 10-11 tahun, maka elemen-elemen pada ekologi pembelajaran, seperti pengalaman belajar sebelumnya, level kognitif, tingkat perkembangan siswa, karakteristik tujuan akhir, dan sebagainya, menjadi hal yang perlu direkayasa sedemikian sehingga membantu tercapianya tujuan pembelajaran yang diharapkan.

Gravemeijer \& Cobb (2006) kemudian merumuskan orientasi validation studies berdasarkan pandangan Cobb et al. (2003) tentang design experiments, yaitu validation studies bertujuan untuk mengembangkan teori pembelajaran pada domain tertentu (domainspesific instruction theory), misalnya teori pembelajaran pada domain matematika, sains, bahasa, dan sebagainya.

Pengembangan domain-spesific instruction theory ini dapat dilakukan di salah satu atau keseluruhan dari level-level berikut ini:

1) Level kegiatan pembelajaran (micro theory), misalnya mengembangkan kegiatan pembelajaran untuk membantu siswa sekolah dasar memahami konsep variabel dalam aljabar.

2) Level lintasan pembelajaran (Local Instruction Theory), misalnya mengembangkan dugaan lintasan pembelajaran (Hypothetical Learning Trajectory) untuk memperkenalkan konsep aljabar pada level sekolah dasar.

3) Level pembelajaran pada domain tertentu (domain-spesific instruction theory), misalnya mengembangkan pembelajaran atau kurikulum pembelajaran matematika berbasis Pembelajaran Matematika Realistik (PMR).

Tidak jauh berbeda dengan tahapan development studies (hanya perbedaan istilah saja), tahapan validation studies terdiri atas 3 tahapan sebagai berikut:

\section{1) Persiapan Eksperirmen}

Meliputi kegiatan penentuan tujuan perancangan, perancangan draf pembelajaran (micro theory, local instruction theory, atau domain-spesific instruction theory), dengan memperhatikan karakteristik tujuan pembelajaran dan keadaan/perkembangan siswa, serta dengan memperhatikan litertur yang terkait. Selain itu, pada tahap ini juga dikembagkan kerangka kerja untuk menginterpretasi kualitas rancangan. 


\section{2) Eksperimen Rancangan}

Tahapan dimana draf rancangan pembelajaran (yang dirumuskan pada tahapan sebelumnya) diujicoba, dievaluasi (formatif), dan direvisi untuk mendapatkan rancangan pembelajaran yang valid. Bersamaan dengan proses ujicoba-evaluasi-revisi tersebut, pemahaman bagaimana rancangan tersebut bekerja juga dikembangkan.

\section{3) Analisis Retrospektif}

Tahapan dimana seluruh data kegiatan Validation Studies di atas dianalsis dan direfleksi guna merumuskan teori pembelajaran (teori intervensi) pada konteks pengembangan di atas.

(DiSessa \& Cobb, 2014) menegaskan bahwa "the practical contribution of designr research (validation studies-red) lies in developing empirically-grounded prototypical learning trajectories that may be adopted and adapted by others.", yaitu pengembangan prototipe lintasan belajar atau Hypothetical Learning Trajectory (HLT) berbasis empirically-grounded (istilah yang digunakan untuk merujuk pada proses konstruksi teori berdasarkan analsis data empiris) adalah bentuk kontribusi praktis dari kegiatan design research (dalam hal ini validation studies) dimana kontribusi tersebut dapat diadopsi (digunakan) atau diadaptasi (disesuaikan penggunaannya) oleh orang lain pada konteks yang serupa.

\section{e) Kombinasi Development Studies dan Validation Studies}

Memahami perbedaan antara development studies dan validation studies adalah sesuatu yang sangat penting dan fundamental secara konseptual karena kedua tipe design research tersebut mengarahkan pada penekanan yang berbeda, baik pada prosedur pelaksanaan dan juga pada karakteristikdari output yang dihasilkannya.

Salah satu contoh yang menarik untuk riset yang mengkombinasikan development studies dan validation studies adalah design research yang dilakukan oleh (Fauzan, 2002). Dalam penelitian ini, Fauzan bertujuan untuk mengembangkan kurikulum (struktur, kegiatan dan perangkat) yang inovatif dan efektif untuk pembelajaran geometri pada Sekolah Dasar di Indonesia dengan mengadopsi karakteristik Pendidikan Matematika Realistik (Realistic Mathematics Education). Dalam hal ini, penelitian ini digolongkan development 
studies. Tapi dalam hal yang bersamaan, penelitian oleh Fauzan ini juga bertujuan untuk menguji efektivitas dari pembelajaran matematika realistik (yang sebelumnya telah terbukti pada konteks sekolahsekolah dasar di Belanda dan Amerika Serikat) pada konteks sekolahsekolah dasar di Indonesia. Maka, dalam hal ini penelitian ini tergolong validation studies.

Contoh penelitian yang serupa juga dilakukan oleh (PUTRAWANGSA et al., 2014). Penelitian ini bertujuan untuk mengembangkan intervensi pembelajaran untuk membantu siswa memahami konsep satuan pengukuran luas pada siswa sekolah dasar (development studies), dan pada saat yang bersamaan penelitian ini juga menguji efektivitas Pembelajaran Matematika Realistik (PMR) dalam menciptakan suasana pembelajaran yang efektif, aktif, dan menyenangkan (validation studies).

\section{f) Rumusan masalah dalam Design Research}

Sebagaimana telah dipaparkan sebelumnya bahwa design research sebagai suatu pendekatan penelitian bertujuan tidak hanya untuk mengembangkan intervensi guna menyelesaikan masalah praktik kependidikan yang sifatnya kompleks, akan tetapi juga berusaha merumuskan karakteristik intervensi tersebut atau disebut dengan istilah teori intervensi, yaitu jawaban atas pertanyaa apa, bagaimana dan mengapa intervensi tersebut efektif dan efisien untuk mencapai tujuan yang diharapakan. Dengan demikian, pertanyaan penelitian dalam design research cenderung pada investigasi karakteristik dari suatu intervensi yang dapat dinyatakn dengan format prase berikut ini:

a) "Apa karakteristik dari intervensi $X$ dalam konteks $Z$ untuk tujuan Y?"

Contoh formulasi pertanyaan penelitian kegiatan desain pembelajaran yang menggunakan format prase di atas, antara lain: "Apa karakeristik kurikulum IRME yang valid, praktis, dan efektif untuk pembelajaran tentang luas dan keliling pada siswa kelas 4 sekolah dasar di Indonesia" (Fauzan, 2002). Dalam pertanyaan penelitian tersebut, bentuk intervensinya adalah pengembangan kurikulum IRME pada topik luas dan keliling. Sedangkan konteks pengembangannya adalah pada siswa kelas 4 sekolah dasar di Indonesia. Sedangkan tujuan 
pengembangannya adalah merumuskan karakteristik kurikulum IRME yang valid, praktis dan efektif.

b) Contoh lainnya, yaitu "Apa karakteristik dari kegiatan pelatihan yang efektif bagi guru-guru sekolah dasarguna meningkatkan keterampilan mereka dalam mengaplikasikan pembelajaran yang berpusat kepada siswa?" Dalam pertanyaan penelitian ini, bentuk intervensinya adalaha merancang dan mengembangkan bentuk kegiatan pelatihan yang efektif. Guru-guru sekolah dasar adalah konteks dimana intervensi itu akan dikembangkan. Tujuan dari pengembangan intervensi tersebut adalah untuk meningkatkan keterampilan dalam mengaplikasikan pembelajaran yang berpusat pada siswa.

Perlu dipahami bahwa tidak semua pertanyaan penelitian deisgn desearch dinyatakan dalam format prase di atas. Ada berbagai cara pengembang menyampaikan pertanyaan penelitiannya. Meskipun prase penyampaiannya berbeda, pertanyaan penelitian dalam Design Research selalu bertujuan untuk mencari atau menemukan karakteristik dari suatu intervensi, seperti pertanyaan penelitian desain pembelajaran oleh (Knipples \& Josephina, 2002) berikut ini: “Apa bentuk kegiatan pembelajaran yang memadai tentang konsep genetika pada pembelajaran biologi sekolah menengah atas untuk membantu mengatasi kesulitan utama siswa dalam pembelajaran genetika dan untuk meningkatkan pemahaman mereka tentang penomena pewarisan sufat yang bermakna dan koheren?". Dalam pertanyaan penelitian ini, yang menjadi bentuk intervensinya adalah pengembangan kegiatan pembelajaran tentang konsep genetika pada konteks pembelajaran biologi sekolah menengah atas. Terdapat dua tujuan dalam kegiatan pengembangan ini: 1) mengatasi kesulitan siswa dalam belajar genetika, dan 2) memberikan pemahaman yang bermakna dan koheren tentang penomena pewarisan sifat.

Contoh lainnya adalah pertanyaan penelitian tentang desain pembelajaran oleh (Wijaya, 2008), yaitu "Bagaimana permainan game siswa dijadikan sebagai sumber pembicaraan mengenai konsep pengukuran linear?". Dalam pertanyaan penelitian ini, bentuk intervensi tidak secara eksplisit disebutkan. Tapi, jika dilihat dari konteks kalimatnya dapat dipahami bahwa bentuk intervensi yang dimaksud adalah pengembangan kegiatan pembelajaran. Sedangkan tujuan dari pengembangan intervensi tersebut adalah menemukan karakteristik 
pembelajaran yang dapat membantu siswa memahami konsep pengukuran linear melalui investigasi permainan game. Sedangkan konteks dari kegiatan pengembangan tersebut adalah pada siswa yang mempelajari konsep pengukuran tersebut. Jadi, dalam pertanyaan penelitian ini, bentuk, konteks dan tujuan intervensi tidak secara lugas disampaikan, akan tetapi berdasarkan konstruksi kalimat, ketiga hal tersebut telah disampaikan dengan baik.

(Sohilait, 2019) melakukan penelitian dengan judul DESAIN PEMBELAJARAN BERBASIS PENDEKATAN MATEMATIKA REALISTIK DENGAN MENGGUNAKAN MASALAH KONTEKSTUAL, mengajukan pertanyaan desain penelitian dengan judul : "Bagaimana lintasan belajar siswa menggunakan pendekatan Pendidikan Matematika Realistik (PMR) dengan konteks masalah kontekstual dapat berkembang dari tahap informal ke tahap formal?". Dalam pertanyaan penelitian ini, bentuk intervensi tidak secara eksplisit disebutkan. Tetapi, jika dilihat dari konteks kalimatnya dapat dipahami bahwa bentuk intervensi yang dimaksud adalah pengembangan desain pembelajaran. Tujuan dari pengembangan intervensi tersebut adalah menghasilkan lintasan belajar siswa menggunakan pendekatan Pendidikan Matematika Realistik (PMR) dengan konteks membagi beras yang berkembang dari tahap informal ke tahap formal. sedangkan konteks dari kegiatan pengembangan tersebut adalah membagi beras. Jadi, dalam pertanyaan penelitian ini, bentuk, konteks dan tujuan intervensi tidak secara lugas disampaikan, akan tetapi berdasarkan konstruksi kalimat, ketiga hal tersebut telah disampaikan dengan baik.

Sedangkan, (PUTRAWANGSA et al., 2014) mengajukan pertanyaan penelitian desain pembelajaran berikut ini: "Bagiaman kita dapat membantu siswa dalam mengembangkan pemahaman mereka tentang strategi perkalian dalam pengukuran luas". Bentuk intevensi dan konteks intervensi tidak disampaikan secara eksplisit dalam pertanyaan penelitian ini. Meskipun demikian, dapat kita pahami berdasarkan konteks kalimat tersebut bahwa peneliti bermaksud mengembangkan kegiatan pembelajaran sebagai bentuk intervensinya, dengan tujuan pengembangan yaitu mengembangkan pemahaman siswa tentang strategi perkalian dalam pengukuran luas. Konteks dalam penelitian ini adalah siswa yang sedangmempelajari konsep tersebut.

\section{g) Masalah yang relevan dengan Design Research}

Memperhatikan definisi dari design research di atas, maka masalah pendidikan yang seperti apa yang relevan untuk dijakukan atau diselesaikan 
dengan pendekatan design research? Atau Kapan design research relevan untuk digunakan?

Untuk menjawab pertanyaan di atas, kita mulai dari menjawab pertanyaan: Kapan design research tidak relevan untuk digunakan? Kelly (2010) menyatakan bahwa:

"if the problem has a knownor standard solution, and there is general agreement on when to apply the solution, and the solution has been regularly successfully applied in various settings, Design Research is probably a poor use of resource"

Dalam pernyataannya di atas, Kelly ingin menegaskan bahwa design research tidak tepat untuk diterapkan jika ingin menemukan solusi untuk masalah yang memiliki solusi yang sudah jelas dan terstandar dimana orangorang sudah memahmi dengan baik kapan harus menggunakan solusi tersebut dan diketahui bahwa solusi tersebut selalu berhasil menyelesaikan masalah yang dimaksud. Dalam kata lain, design research tidak sesuai untuk digunakan jika diperuntukkan untuk menyelesaikan masalah yang relatif sederhana.

Jika demikian, kapan design research relevan untuk digunakan? Kelly dalam (Plomp \& Nieveen, 2013) kembali menegaskan bahwa:

"Design Researchis recommended when the problem facing learning or teaching is substantial and dounting how-to-do guidelines available for addressing the problems are unavailable"

Dalam pernyataannya di atas, Kelly menerangkan bahwa design research dapat direkomendasikan untuk menyelesaikan masalah-masalah yang sifatnya substansial dan belum ditemukan pedoman penyelesainnya. Jikapun ada pedoman penyelesaiannya, pedoman tersebut masih diperdebatkan. Kelly lebih lanjut menegaskan bahwa design research juga tepat digunakan untuk menyelesaikan masalah-masalah pendidikan yang telah memiliki solusi namun solusi tersebut terbukti kurang efektif atau terbukti tidak efektif berdasarkan kajian literatur atau berdasarkan suatu kajian terhadap solusi tersebut.

Dalam dunia pendidikan, Kelly (2010) menggambarkan situasi design research untuk diterapkan, yaitu:

a) Ketika konten/isi pengetahuan yang akan dipelajari bersifat relatif baru, belum jelas, atau masih dalam proses penemuan.

b) Ketika bagaimana cara mengajarkan konten tertentu belum jelas atau belum efektif.

c) Ketika bahan atau perangkat untuk mengajarkan konten tertentu belum jelas atau belum efektif. 
d) Ketika pengetahuan atau keterampilan guru masih belum memuaskan.

e) Ketika pemahaman peneliti kependidikan tentang konten, bahan, perangkat, atau strategi terhadap suautu pembelajaran masih minim.

f) Ketika faktor yang kompleks dari masyarakat, kebijakan, dan politik mempengaruhi perkembangan pendidikan.

Berikut beberapa contoh masalah pendidikan dimana design research dianggap sesuai untuk menyelesaikan masalah tersebut:

a) Mengingat aspek historis memberikan dampak yang signifikan terhadap pemahaman siswa sekolah dasar terhadap suatu konten pembelajaran, edukator dalam bidang Sains masih belum menemukan formula yang tepat bagiamana mengadopsi dan mengintegrasi aspek historis dari Sains dalam suatu pembelajaran Sains. Hal ini mengarahkan pada pertanyaan "Bagaimana mengintegrasikan kajian historis pada pembelajaran Sains guna meningkatkan pemahaman siswa tentang Sains?".

b) Pemahaman siswa sekolah dasar tentang pecahan tergolong sangat buruk meski berbagai strategi pembelajaran telah diterapkan. Hal ini mengarahkan pada pertanyaan "bagaimana membantu siswa sekolah dasar untuk memahami konsep pecahan dengan benar".

c) Pemahaman dan keterampilan mahasiswa calon guru tentang implementasi pembelajaran yang berpusat pada siswa masih minim. Salah satu penyebabnya adalah kegiatan microteaching yang diikuti mahasiswa tersebut belum berorientasipeningkatan pemahaman dan keterampilan mahasiswa dalam melaksanakan pembelajaran yang berpusat pada siswa. Masalah ini mengarahkan pada pertanyaan "Apa karakeristik dari kegiatan microteaching yang efektif untuk mahasiswa calon guru agar memiliki pemahaman dan keterampilan dalam melaksanakan pembelajaran yang berpusat pada siswa.

h) Mengakhiri Design Research

Salah satu karakteristik dari design research adalah sifatnya yang iteratif (berulang-ulang dalam suatu siklus pengembangan). Jika intervensi yang dikembangkan belum juga menghasilkan sesuatu yang diharapkan, maka dapat disimpulkan bahwa intervensi tersebut beserta teori intervensi yang melatarbelakanginya dianggap belum efektif untuk mencapai tujuan yang diharapkan. Dengan demikian, intervensi beserta teori intervensi tersebut 
perlu diperbaiki atau dirancang ulang kembali, kemudian diujicoba kembali pada siklus berikutnya (dikembangkan kembali). Jika pada ujicoba berikutnya intervensi tersebut belum efektif juga, maka perbaikan dan perancangan ulang perlu dilakukan kembali dan seterusnya. Siklus ini dapat diakhiri jika intervensi tersebut 'dianggap' efektif atau cukup efektif untuk mencapai tujuan yang diharapkan. Proses ini menunjukkan bahwa setiap siklus menjadikan hasil siklus sebelumnya sebagai pertimbangan dalam memperbaiki atau merancang ulang intervensi beserta dengan teorinya (teori intervensi).

Dengan alasan tertentu, misalnya keterbatasan waktu atau pendanaan, dapatkah seseorang mengakhiri kegiatan design research meski intervensi yang dikembangkannya belum dapat dianggap efektif untuk mencapai tujuan? Dalam situasi seperti ini, tentu intervensi yang dikembangkan belum dapat menyelesaikan masalah yang dihadapi dan akibatnya teori intervensi untuk menyelesaikan masalah tersebut belum juga dapat dirumuskan. Meskipun demikian, seseorang dapat mengakhiri kegiatan pengembangan tersebut jika menghadapi kendala yang mengakibatkan tidak mungkinnya kegiatan pengembangan tersebut dilanjutkan. Dalam situasi ini, pengembang diharapkan tatap menghimpun dan melaporkan hasil pengembangannya dengan harapan nantinya proses pengembangan tersebut dapat dilanjutkan oleh pengembang itu sendiri atau oleh pengembang lainnya.

\section{i) Tahapan Design Research dengan berparadigma Pendidikan Matematika Realistik (PMR)}

Dari sekian model design research yang ada, model design research oleh (Van den Akker, 2006) umumnya digunakan untuk kegiatan desain pembelajaran, yaitu kegiatan desain yang bertujuan untuk menguji dan mengembangkan dugaan lintasan belajar siswa (Hypothetical Learning Trajectory) sehingga menghasilkan teori instruksi lokal (Local Instruction Theory). 


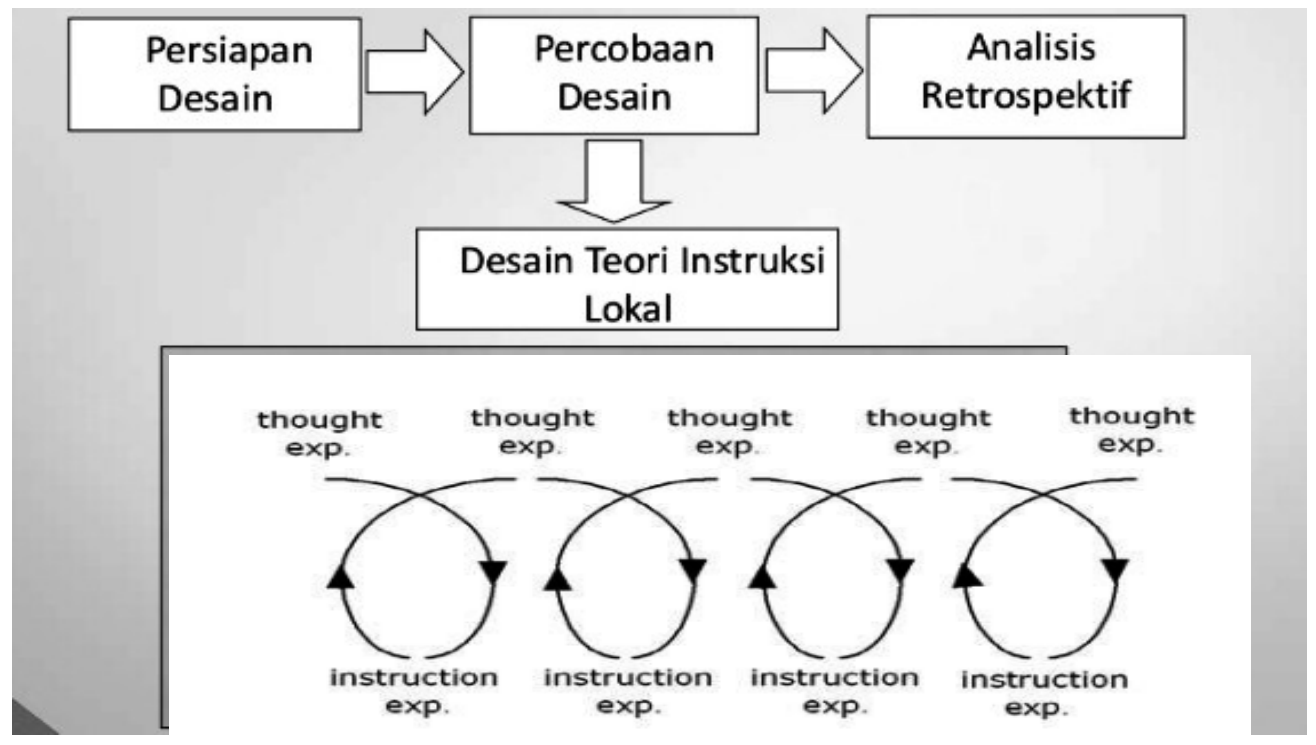

Gambar 6.4. Desain Pembelajaran

Ada tiga tahapan kegiatan desain pembelajaran yaitu sebagai berikut:

\section{1) Tahap Persiapan dan Perancangan}

Pada tahap ini perancang draf desain pembelajaran. Ide awal desain kegiatan pembelajaran tersebut didasarkan pada kajian literatur yang relevan. Berdasarkan kajian tersebut, perancang mulai mendesain serangkaian kegiatan pembelajaran. Dalam desain tersebut, perancang mensintesis berbagai teori belajar yang relevan, sehingga rangkaian kegiatan belajar pada desain tersebut dipandang sebagai sebuah dugaan lintasan belajar, yang kemudian disebut dengan istilah Hypothetical Learning Trajectory (HLT). (Simon, 1995) adalah peneliti pertama yang menggunakan istilah hypothetical learning trajectory (HLT) untuk merepresentasikan proses belajar yang dilalui oleh siswa mulai dari pengetahuan yang dimiliki oleh siswa sampai dengan siswa mencapai tujuan pembelajaran yang ditetapkan oleh guru. Dinamakan lintasan belajar sebagai HLT karena lintasan belajar siswa yang pasti tidak dapat diketahui secara pasti sebelum proses pembelajaran dilakukan.

HLT terdiri dari tiga kompenen utama yaitu:

\section{1) Tujuan pembelajaran (learning goals)}

Apa yang akan dicapai siswa dalam kegiatan pembelajaran ini.

2) Aktivitas pembelajaran (learning activities)

Aktifitas pembelajaran yang dirancang dengan saksama sehingga tujuan pembelajaran tercapai. 


\section{3) Dugaan proses belajar (hypothetical learning process)}

Peneliti menduga di awal tentang bagaimana kegiatan pembelajaran akan berlangsung dan utamanya adalah proses belajar siswa selama kegiatan tersebut. Dengan dugaan-dugaan ini, peneliti dapat mengantisipasi segala kemungkinan di kelas.

HLT selanjutnya akan ditingkatkan kualitasnya melalui serangkain kegiatan validasi, yaitu validasi isi dan konstruksi, dengan melakukan penilaian pakar dan ujicoba terbatas. Akhir dari tahapan ini adalah didapatkannya HLT yang sudah dianggap valid berdasarkan validasi isi dan konstruksi melalui penilaian pakar dan ujicoba terbatas yang telah dilakukan. Hasil yang didapatkan dari tahapan ini kemudian dilanjutkan ke tahap berikutnya, yaitu eksperimen pengajaran.

\section{2) Tahap Experimen Pengajaran}

Tahap selanjutnya dari kegiatan desain pembelajaran ini adalah eksperimen HLT pada suasana pembelajaran sesungguhnya (bukan ujicoba terbatas seperti pada tahap sebelumnya).

Pada tahap ini, HLT yang telah dirancang pada tahap sebelumnya dikembangkan kembali melalui serangkaian ujicoba pemebelajaran untuk menginvestigasi apakah apa yang dihipotesiskan pada HLT sesuai dengan apa yang terjadi pada eksperimen.

Peneliti membuat suatu eksperimen pikiran antisipasi (an anticipatory thought experiment) dengan membayangkan bagaimana aktivitas pembelajaran yang diusulkan dapat direalisasikan dalam interaksi di dalam kelas, dan apa yang siswa pelajari setelah berpartisipasi dalam aktivitas pembelajaran yang dirancang oleh peneliti. Selama pembuatan aktivitas pembelajaran di dalam kelas dan dalam peninjauan kembali, peneliti mencoba untuk menganalisis proses aktual partisipasi dan belajar siswa. Uji coba desain terdiri atas proses-proses siklik dari eksperimen pikiran (thought experiment) dan eksperimen pembelajaran (instruction experiment). Proses siklik dari eksperimen pikiran (thought experiment) dan eksperimen pembelajaran (instruction experiment) oleh (Akker et al., 2006) seperti pada gambar 6.5 berikut. 


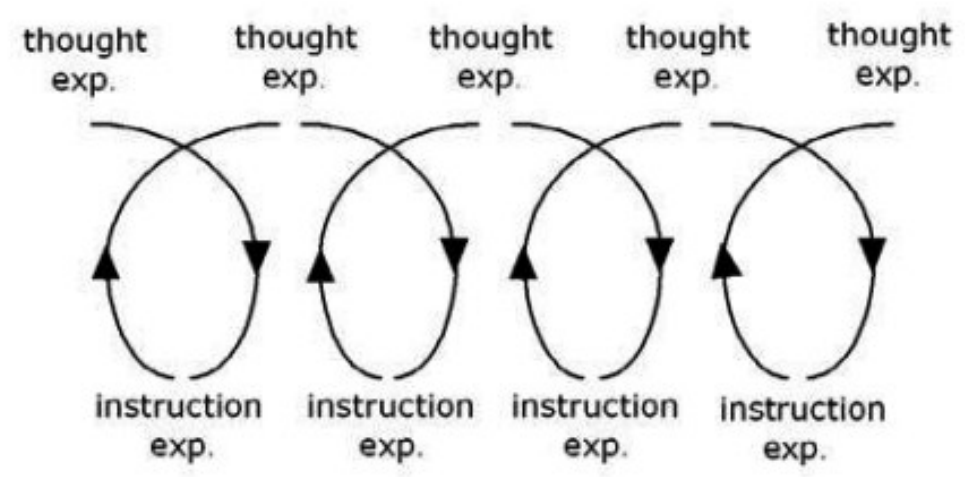

Gambar 6.5. Siklik proses dalam Design Reseacrh

Kita dapat membuat hubungan antara siklus-siklus kecil dari eksperimen pikiran (thought experiment) dan eksperimen pembelajaran (instruction experiment) dengan siklus pembelajaran matematika. Menurut ide Simon, seorang guru matematika harus mencoba mengantisipasi aktivitas mental apa yang terjadi pada diri siswa ketika siswa berpartisipasi dalam suatu aktivitas pembelajaran. Kemudian guru akan mencoba untuk menemukan tingkat proses berpikir siswa yang kemudian dihipotesiskan oleh guru selama proses pembuatan aktivitas pembelajaran berlangsung yang kemudian direvisi setelah pelaksanaan aktivitas pembelajaran.

Tujuan dari eksperimen ini adalah untuk meningkatkan akurasi dari hipotesis atau dugaan yang telah dikembangkan pada HLT, sehingga perancang (peneliti atau guru model) dapat memahami dengan lebih baik efektivitas dan kepraktisan dari HLT tersebut.

\section{3) Tahap Analisis Retrospektif}

Untuk mengetahui apakah desain pembelajaran pada HLT yang telah dirancang efektif dan praktis, maka perancang melakukan serangkaian kegiatan analisis, yang dikenal dengan istilah analisis retrospektif. Analisis retrospektif dilakukan dengan membandingkan antara HLT dengan dengan data yang didapatkan dari kegiatan eksperimen pengajaran pada tahap sebelumnya, yaitu data hasil penerapan HLT.

Dalam hal ini, analisis retrospektif dilakukan setalah eksperimen. Sehingga, kegiatan eksperimen bersama dengan analisis retrospektif membentuk sebuah siklus proses pengembangan dan perancangan.

Dalam analisis ini, rekaman video pembelajaran beserta transkirp diteliti satu demi satu secara kronologis dengan tujuan menguji hipotesis kegiatan dan lintasan belajar pada HLT dengan kegiatan pembelajaran sesungguhnya. 
Sumber data lainnya seperti catatan lapangan, hasil kerja siswa, hasil tes, dan sebagainya adalah sumber untuk melakukan triangulasi.

Melalui analisis retrospektif ini, teori pembelajaran (teori intervensi) yang dikembangkan pada HLT ditingkatkan kualitasnya melalui siklus eksperimenanalisis retrospektif. Dengan demikian, bentuk intervensi dalam model desain pembelajaran ini tertuang dalam HLT, sedangkan teori intervensinya adalah alasan teoritis yang mendasari HLT tersebut.

Contoh : Hypothetical Learning Trajectory(HLT) (Mangelep, 2011)

\section{KONTEKS MEMBAGIROTI \\ DALAM MEMPELAJARI \\ LUAS SEGITIGA}

\section{Pendahuluan}

Pembelajaran matematika saat ini sudah cukup lama terbenam dalam pembelajaran matematika yang bagi banyak orang terasa asing, formal, dan hanya bermain angka atau simbol yang sulit dan serba tak berarti, bahkan tidak sedikit yang merasa ketakutan untuk menghadapi pelajaran matematika. Begitu pula dalam pembelajaran Geometri seperti luas segitiga. Guru di sekolah cenderung langsung memberikan rumus dan bagaimanamenggunakan rumus tersebut untuk menyelesaikan soal yang ada, sehingga siswa tidak mengetahui makna dari simbol-simbol yang mereka gunakan. Hal inimembuat pembelajaran matematika menjadi tidak menyenangkan karena hanya diajarkan dengan cara mekanistik.

Sudah saatnya pembelajaran matematika khususnya pada pembelajaran luas segitiga di kemas dalam pembelajaran yang ashik dan menyenangkan. Salah satu pendekatan pembelajaran yang tepat dalam menanamkan konsep dengan cara yang menyenangkan adalah pendekatan Pendidikan Matematika Realistik Indonesia (PMRI).

Pada pelaksanaan desain riset di SD IGM Palembang ini, diharapakan pembelajaran materi luas segitiga dapat dengan menggunakan pendekatan PMRI dapat meningkatkan pemahaman konsep dan dapat membantu siswa dalam menyelesaikan soal-soal yang berkaitan dengan materi luas segitiga.

\section{Desain Riset}

\section{1) Preliminary Design}

Sebelum melaksanakan desain riset, observer terlebih dahulu membuat desain pembelajaran luas segitiga dengan mengacu pada kurikulum matematika SD yang ada. Hal ini dimaksud agar desain pembelajaran yang dihasilan sesuai dengan kurikulum dan arah 
pengembangan pembelajaran matematika yang sesuai dengan standar isi dan standar proses yang telah di tetapkan oleh Badan Standarisasi Nasional Pendidikan (BSNP) Indonesia. Selain itu, hal ini dapat menjadi acuan dalam pengembangan desain pembelajaran itu sendiri.

Berdasarkan kurikulum KTSP 2006 pembelajaran materi luas segitiga termasuk dalam pokok bahasan geometri dan pengukuran. Berikut ini tabel Standar Kompetensi dan Kompetensi Dasar pembelajaran materi luas segitiga untuk SD Kelas IV:

\begin{tabular}{|l|c|}
\hline \multicolumn{1}{|c|}{ Standar Kompetensi } & \multicolumn{1}{|c|}{ Kompetensi Dasar } \\
\hline $\begin{array}{l}\text { 4. Menggunakan konsep } \\
\text { keliling dan luas } \\
\text { bangun datar } \\
\text { sederhana dalam } \\
\text { pemecahan masalah }\end{array}$ & $\begin{array}{c}\text { Menentukan keliling dan } \\
\text { luas jajargenjang dan } \\
\text { segitiga } \\
\text { Menyelesaikan masalahyang } \\
\text { berkaitan dengan keliling dan } \\
\text { luas jajargenjang dan segitiga }\end{array}$ \\
& \\
& \\
\hline
\end{tabular}

Tabel 1. SK dan KD materi Luas Segitiga

Dari hasil analisis kurikulum ini maka dibuatlah draf desain pembelajaranluas segitiga yang kemudian didiskusikan dengan guru matapelajaran dan dikembangkan lebih lanjut dengan analisis berdasarkan konjektur pemikiran siswa. Sehingga aktivitas-aktivitas yang ada dalam desain pembelajaran ini, dapat benar-benar menuntun siswa dalam memahami konsep luas segitiga dengan baik.

Berikut ini beberapa aktivitas siswa pada pembelajaran luas segitiga dan analisis konjektur pemikiran siswa dalam melaksanakan kegitan pembelajaran tersebut:

Aktivitas 1: Memontong Roti \& Membandingkan Potongan Roti yang dibuat

Tujuan dari aktifitas ini adalah menuntun siswa untuk mengetahui konsep luas dengan cara membandingkan 2 bentuk bangun datar melalui roti yang mereka potong. Hal ini perlu dilakukan karena luas 
merupakan suatu atribut pada bidang datar yang dapat dibandingkan dan di urutkan dengan melihatbentuknya. Di harapkan dengan aktifitas ini siswa dapat mendapatkan pengetahuan awal mengenai konservasi luas dengan cara membandingkan 2 bangun datar yang ada. jika siswa sudah memahamo makn dari konservasi luas, maka mereka dapat dengan mudah untuk membandingkan dan engurutkan daerah-daerah bidang datar tersebut.

Deskripsi Aktivitas:

- Pada aktivitas ini, pertama-tama guru akan bercerita kepada siswa tentang masalah kontekstual dimana ada seorang ibu bernama Tuti yang membagikan roti kepada kedua anaknya. Ibu Tuti membagi 2 roti menjadi 2 bagian yang sama besar dengan bentuk yang berbeda. Roti pertama dipotong menjadi 2 bagian yang berbentuk segi empat, sedangkan roti kedua dipotong menjadi 2 bagian yang berbentuk segitiga. Ketika Ibu Tuti membagikan roti tersebut kepada kedua anaknya, kedua anak tersebut bertengkar karena merasa bahwa roti mereka tidak sama besar dan mereka menganggap bahwa itu suatu ketidakadilan. Bagaimana Ibu Tuti menjelaskna hal ini kepada kedua anaknya? Kemudian guru memanggil seorang siswa dan meminta siswa tersebut melakukan situasi yang ibu Tuti alami. Hal inipun diikuti oleh siswa-siswa yang lain. Kemudian guru mengajak siswa untuk membandingkan kedua roti yang telah mereka potong tadi dan bagaimana cara mereka membandingkannya.

Konjektur Pemikiran Siswa :

- Siswa bisa saja menjawab hanya dengan menebak bahwa bangun datar yang satu lebih besar dari yang satunya ataupun sama besar. Strategi ni merupakan kemampuan mental anak dengan hanya membanyangkan tiap-tiap objek yang mereka bandingkan.

- Siswa bisa saja menumpukan kedua roti tersebut, kemudian mereka melihat dan menghitung bagian yang berlebih atau bersisa.

- Siswa bisa saja menggunakan penggaris untuk menentukan roti mana yang paling besar ataupun sama besar, namun strategi ini 
membawa siswa ke situasi mencari keliling suatu objek dan akhirnya siswa akan menjumlahkan panjang setiap sisi.

- Siswa bisa saja mengambar kedua bangun tersebut kedalam kertas berpetak dan menggunakan unit-unit satuan yang ada pada kertas berpeta untuk menjadi tolak ukur (benchmark) dalam menentukan ukuran dar roti yang mereka potong tadi. Dengan cara ini siswa akan menghitung satu-persatu jumlah kotak yang terdapat pada gambar roti pada kertas berpektak yang mereka buat. Strategi ini menunjukkan bahwa diperlukan suatu tolak ukur (benchmark) untuk membandingkan 2 bangun datar yang ada. Tolak ukur yang dibayangkan siswa ni merupakan unit pengukuran yang membant mereka memahami konsep luas segitiga yang mereka pelajari.

Aktivitas 2: Menentukan Luas Segitiga dengan menggunakan Pendekatan Luas Persegi

Tujuan dari aktivitas ini adalah mengaplikasikan konsep perbandingan luas yang telah siswa lakukan pada aktivitas sebelumnya dan menemukan rumus luas segitiga.

Deskripsi Aktivitas:

- Pada aktivitas ini, siswa akan membandingkan bangun datar persegi dan segitiga yang mereka peroleh dari potongan roti yang mereka telh potong. Namun pada tahap ini siswa tidak lagi menggunakan unit satuan seperti pada aktivitas sebelumnya. Pada aktivitas ini, siswa dituntun untuk mengaplikasikan konsep luas persegi yang mereka telah ketahui sejak dari kelas III SD. Guru akan menuntun siswa untuk bagaimana mencari hubungan luas persegi dengan segitiga yang dihasilkan dari potongan persegi (roti) yang mereka lakukan sebelumnya Konjektur Pemikiran Siswa :

- Siswa bisa langsung menyimpulkan bahwa luas segitiga merupakan setengah dari luas persegi yang mereka buat. Hal ini dikarenakan mereka telah mengetahui konsep membandingkan 2 benda sebelumnya.

- Siswa bisa saja menebak hubungan luas segitiga dan luas persegi. Jika demikian guru harus menuntun siswa dengan pertanyaanpertanyaan lanjutan yang membuat siswa berikir tentang konsep yang sebenarnya. 
- Siswa bisa membandingkan luas segitiga dan persegi namun siswa belum bisa mengaitkan antar panjang dan lebar pada persegi dan alas dan tinggi pada segitiga. Jika hal ini terjadi guru dapat berperan sebagai fasilitator danmembantu menemukan jawaban persoalan tersebut dengan membangun diskusi kelas dengan siswa lain, sehingga siswa dapat menemukan solusi dari pemasalahan tersebut dari siswa yang lain.

Dari hasil preliminary design diatas maka didapat rancangan iceberg pembelajaran materi luas segitiga sebagai berikut:

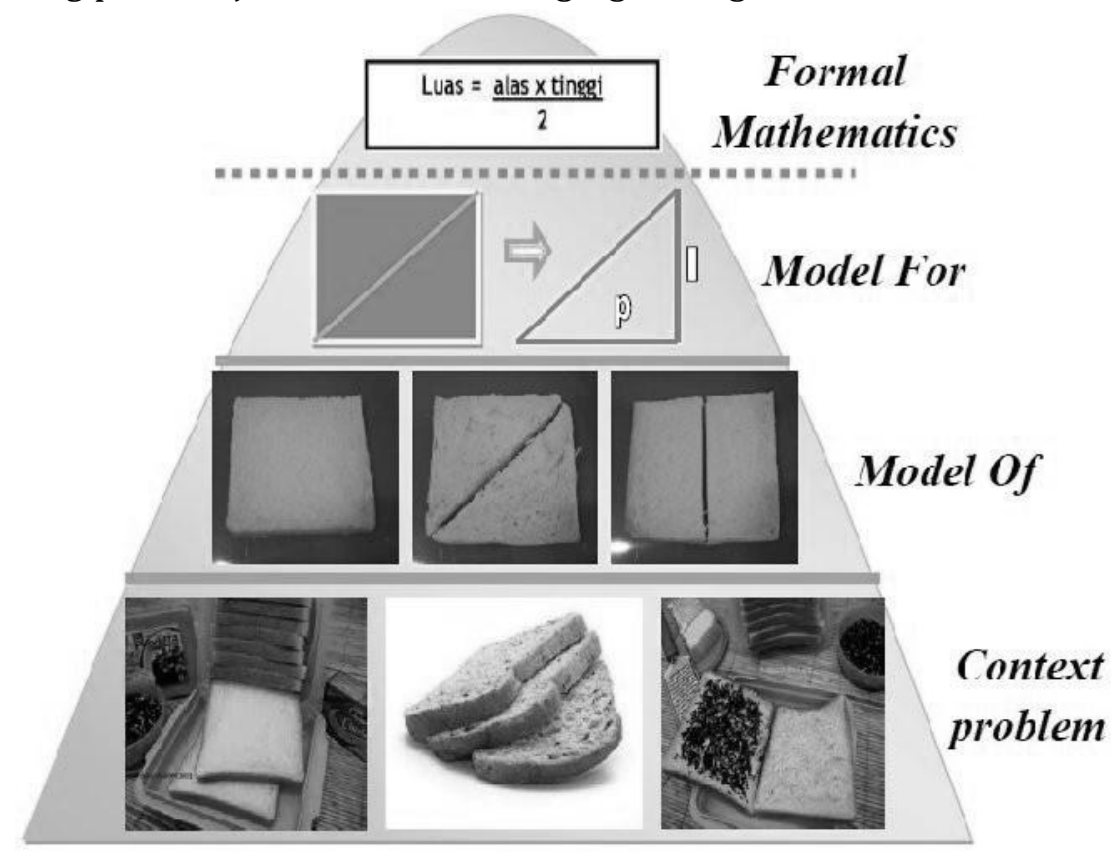

Gambar 1. Rancangan Iceberg pembelajaran Luas Segitiga

\section{2) Teaching Experiment}

Proses pembelajaran yang dilaksanakan dengan desain riset ini berlangsung dalam1 tatap muka selama 1 jam pelajaran (35 Menit waktu normal). Pembelajaran diawali dengan guru menyampaikan tujuan pembelajaran dan mengingatkan kembali pelajaran sebelumnya yang berkaitan dengan segitiga seperti jenis-jenis segitiga dan unsur-unsur segitiga. Hal ini dilakukan untuk mengetahui sejauh mana kemampuan awal yang dimiliki siswa untuk mengingikuti pembelajaran selanjutnya. Kemudian siswa dikelompokkan menjadi beberapa kelompok dimana setiap kelompok terdiri dari 3-4 orang per kelompok dan guru meminta 
siswa untuk memberi nama pada setiap kelompoknya masingmasing.

Sebelum masuk dalam tahap pemberian masalah kontekstual

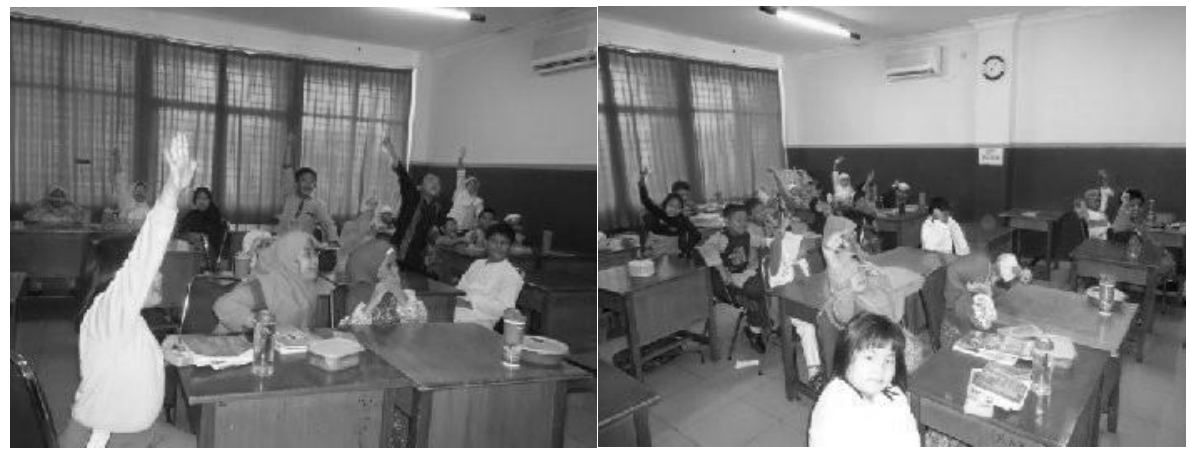

sesuai dengan langkah-langkah pembelajaran dengan menggunakan pendekatan PMRI, guru terlebih dahulu memotivasi siswa dengan melakukan tanya jawab dengan siswa mengenai konteks roti. Guru menanyakan kepada siswa siapakah yang pernah makan roti dan bagaimana rasanya, kemudian guru meminta siswa untuk menceritakan pengalamannya.

Gambar 2. Siswa antusias untuk Menceritakan Pengalamannya pada saat Makan Roti

\section{Tahap Pemberian Masalah Kontekstual}

Pada tahap ini guru memberikan masalah kontekstual kepada siswa berupa cerita dimana ada seorang ibu bernama Tuti yang membagikan roti kepada kedua anaknya. Ibu Tuti membagi 2 roti menjadi 2 bagian yang sama besar dengan bentuk yang berbeda. Roti pertama dipotong menjadi 2 bagian yang berbentuk segi empat, sedangkan roti kedua dipotong menjadi 2 bagian yang berbentuk segitiga. Ketika Ibu Tuti membagikan roti tersebut kepada kedua anaknya, kedua anak tersebut bertengkar karena merasa bahwa roti mereka tidak sama besar dan mereka menganggap bahwa itu suatu ketidakadilan. Bagaimana Ibu Tuti menjelaskan hal ini kepada kedua anaknya? Kemudian guru memanggil seorang siswa dan meminta siswa tersebut melakukan situasi yang ibu Tuti alami. Dan situasi inipun di coba pada setia kelompok.

Siswa diberi 2 roti dan guru memintanya untuk memotong salah satu roti menjadi 2 bagian berbentuk segiempat, dan roti 
selanjutnya dibagi menjadi 2 bagian juga yang berbentuk segitiga. Kemudian guru meberikan pertanyaan lanjutan kepada

siswa. "bagaimana menurut kalian, apakah kedua bagian roti yang berbentuk segitiga dan segiempat sama besar? jika tidak coba kemukakan alasanmu. Spontan ada siswa yang menjawab sama besar, namun tidak sedikit juga yang mengatakan bahwa keduanya tidak sama besar. Pada tahap ini guru memberikan kesempatan seluas-luasnya kepada siswa untuk mengemukakan pendapatnya.

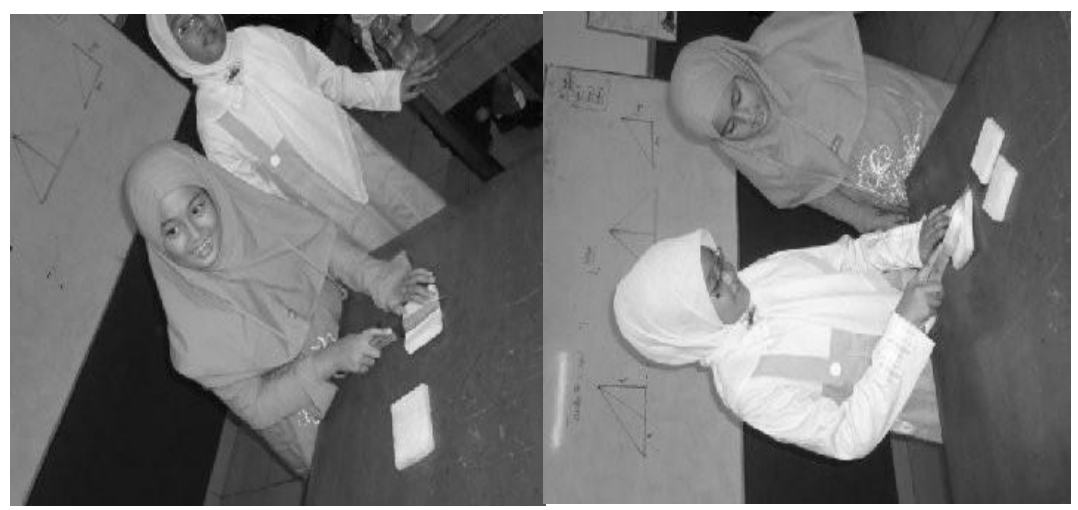

Gambar 3. Siswa Memotong Roti menjadi 2 bagian

\section{Tahap Menjelaskan Masalah Kontekstual}

Pada tahap ini, guru memberikan kesempatan kepada siswa yang belum memahami permasalahan yang diberikan untuk bertanya tentang masalah kontekstual yang ada. Melalui penjelasan yang diberikan, siswa dapat mengindentifikasi permasalahan dan mencari cara yangcocok untuk menyelesaikan permasalahan tersebut. Hal ini dilakukan berdasarkan karakteristik PMRI yang ke-4 yaitu adanya interaktifitas pada proses pembelajaran, baik sesama siswa, maupun siswa dengan guru.

\section{Tahap menyelesaikan masalah kontektual (Aktivitas I)}

Pada tahap ini, gurupun menanyakan kepada siswa, bagaimana pendapat mereka mengenai roti yang telah dibagi tersebut. Kenapa ada siswa yang mengatakan bahwa potongan roti yang berbentuk segiempat lebih besar dari potongan roti yang berbentuk segitiga? Dari pertanyaanpertanyaan ini muncul beberapa ide penyelesaian dari siswa. 
Ada yang mengukurnya dengan mistar, ada yang menumpukkan kedua roti tersebut dan memperkirakan sisa dari hasil tumpukkan tersebut, dan ada pula yang mencoba menggambarnya dibuku.

Melihat hal tersebut, guru pun membimbing mereka pertanyaan-pertanyaan lanjutan sebagai penuntuk mereka untuk memahami konsep luas. Pada tahap ini Setelah masalah kontekstual yang diberikan telah dipahami oleh siswa dan situasi yang riil tersebut telah dirasakan dan dialami oleh siswa, maka guru memfasilitasi siswa untuk masuk ketahap selanjutnya, yakni tahap pemecahan masalah. Pada tahap ini, guru memberikan LKS 1 sebagai penuntun siswa untuk memahami dan mencari cara/teknik dalam menyelesaikan masalah yang diberikan.
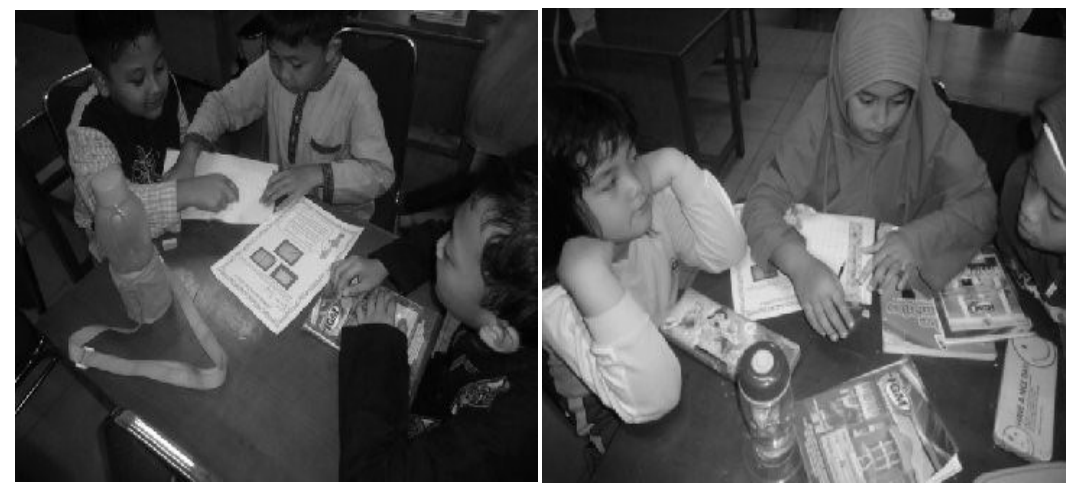

Gambar 4. Siswa berdiskusi untuk menyelesaikan LKS yang diberikan

Dari konteks luas roti tersebut, siswa diminta untuk menggambarkan potongan-potongan roti tersebut kedalam kertas berpetak. Setelah itu, siswa diminta untuk menjawa pertanyaan-pertanyaan yang terdapat dalam LKS 1 tentang konsep luas. Dimana untuk mengetahui luas suatu bangun datar siswa harus membandingkan unit-unit satuan yang dimiliki olehn datar tersebut

\section{Tahap membandingkan dan mendiskusikan jawaban}

Pada tahap ini, siswa diberi kesempatan untuk mempresentasikan hasil diskusi mereka. Disini guru mempersilahkan siswa yang lain untuk menanggapi hasil 
pekerjaan dari kelompok yang maju kedepan. Pada tahap ini terjadi pertukaran informasi, ide dan pendapatdari sesama siswa. Guru bertindak memfasilitasi dan menjadi penengah dalam diskusi ini.

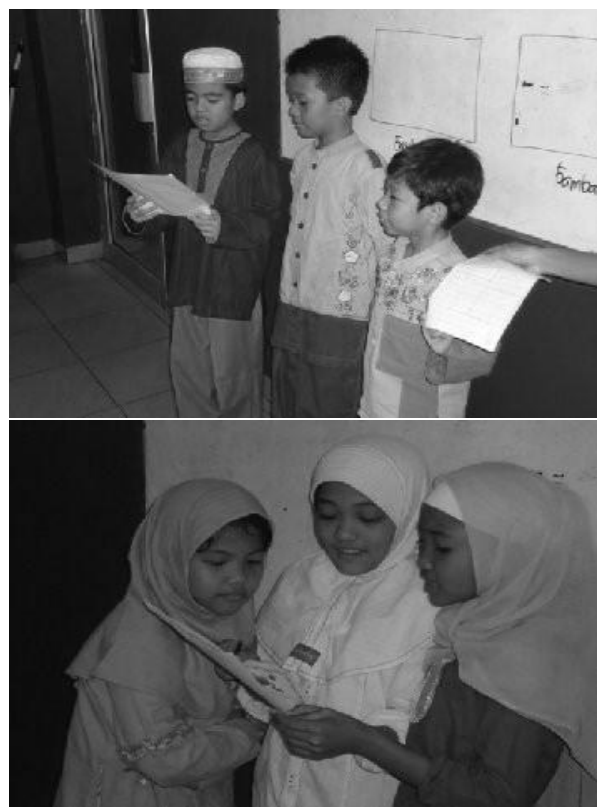

Gambar 5. Siswa mempresentasikan Hasil Diskusi mereka

\section{Tahap pengembangan masalah kontekstual (Aktivitas II)}

Disini siswa dibimbing untuk berdiskusi pada aktifitas kedua dengan mengerjakan Lembar Aktifitas Siswa 2 (LAS 2), dimana siswa berdiskusiuntuk mencari rumus luas segitiga dengan persegi panjang yang ada (Roti yang mereka telah gambar). Kemudian siswadiminta untuk mempresentasikan hasil diskusi merekaseperti sebelumnya.

\section{Tahap Akhir dan Penyimpulan}

Pada tahap ini siswa diajak untuk mengembangkan dan meningkatkan pemahaman mereka dengan mengerjakan soal yang telah disediakan. Dengan pengetahuan dan konsep yang mereka ketahui, siswa dapat menyelesaikan dengan cepat soal-soal yang diberikan. Kemudian guru dan siswa merefleksi dan menyimpulkan kegiatan diskusi yang telah mereka laksanakan dan memberi penegasan-penegasan tentang konsep-konsep yang telah mereka pelajar. 
Berikut ini adalah iceberg pembelejaran luas segitiga yang telah dilaksanakan:

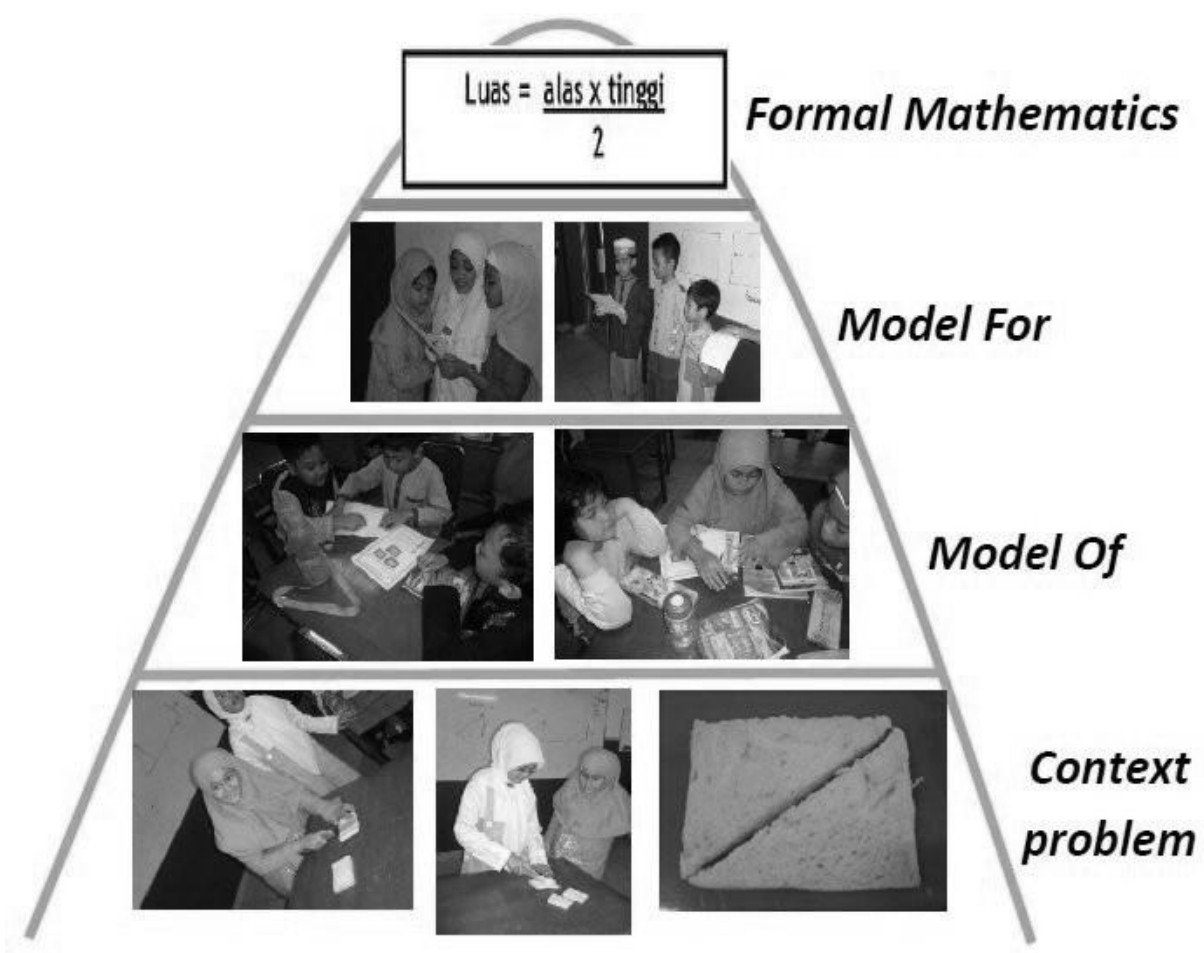

Gambar 6. Iceberg Pembelajaran Luas Segitiga

\section{3) Retrospective Analysis}

Data yang dianalisis pada pelaksanaan desain riset ini diambil pada siswa-siswa kelas 4A SD Plus IGM Palembang yang berjumlah 22 orang dan bekerja secara berkelompok yang terdiri dari 3-4 orang.

Berdasarkan hasil pengamatan pada aktivitas pertama, awalnya siswa kesulitan untuk membandingkan 2 potongan roti yang mereka buat. Rasa takut dan tidak percaya diri siswa menghambat mereka untuk menyampaikan ide-ide mereka. Guru pun butuh waktu untuk merubah suasana ini. Oleh karena itu siswa terus didorong untuk mengemukakan ide-ide mereka.

Pada awal membandingkan siswa saling melihat satu denganyang lainnya dan siswa menebak tanpa mengetahui dengan pasti apakah kedua roti tersebut sama besar, ataukah ada yang lebih besar. Namun ada salah satu siswa yang menggambarkan potongan roti tersebut kedalam bukunya. Gurupun menayakan alasan apa 
sehingga dia melakukan demikian. Siswa tersebut menjawab, bahwa akan lebih mudah membandingkannya jika dalam bentuk gambar. Hal ini menunjukkan bahwa siswa tersebut membutuhkan media untuk membandingkan roti tersebut. Hal ini merupakan awal yang baik untuk memahami konsep luas segitiga.

Dalam LKS 1 siswa dituntun untuk menggambarkan roti tersebut pada kertas berpetak, ketika siswa selesai menggambarkan roti tersebut, guru meminta siswa untuk membadingkan kedua gambar tersebut. Disini siswa dengan mudah membandingkannya dengan menghitung banyaknya kotak yang termasuk pada gambar roti tersebut. Siswa menyadari bahwa kotak-kotak tersebut memiliki ukuran yang sama dan hal ini membantu mereka untuk memahami konsep luas.

Pada tahap ini terjadi perdebatan antar sesamasiswa dimana ada kelompok yang mengatakan bahwa kedua roti tersebut sama besar dan ada kelompok yang mengetakan kedua roti tersebut tidak sama besar. Kemudian guru memberikan kesempatan kepada kelompok 2 (Tasya, Shasa, dan Suriana) untuk menjelaskan alasan mereka mengatakan bahwa kedua potongan roti tersebut tidak sama besar. Tasya menjelaskan bahwa berdasarkan perhitungan mereka, jumlah kotak pada gambar roti pertama hanya 8 kotak,

sedangkan pada roti kedua ada 10 kotak, jadi roti yang berbentuk persegi panjang lebih besar dari roti yang berbentuk segitiga. Kemudian guru memberikan kesempatan kepada kelompok 4 (Aldy, Niken, Caca) untuk mengemukakan pendapat mereka bahwa kedua gambar roti tersebut sama besar. Aldy pun menjelaskan bahwa berdasarkan hasil perhitungan jumlah kotak yang membentuk kedua gambar roti tersebut, mereka mendapatkan hasil yang sama yakni 7,5 kotak. Kemudian guru menanyakan

mengapa mereka bisa mendapatkan jumlah kotak dalam angka koma. Aldy mengatakan bahwa jumlah keseluruhan kotak yang membentuk roti ada 15 kotak, karena roti tersebut dipotong menjadi 2 bagian, maka jumlah kotak menjadi 7,5 kotak. Dan setelah mereka menghitungnya secara manual, didapatkan hasil yang sama. 
Berikut ini hasil pekerjaan dari kelompok 4 pada LKS 1:

Gambar 7. Hasil Pekerjaan Kelompok 4 (Aldy, Niken, Caca)
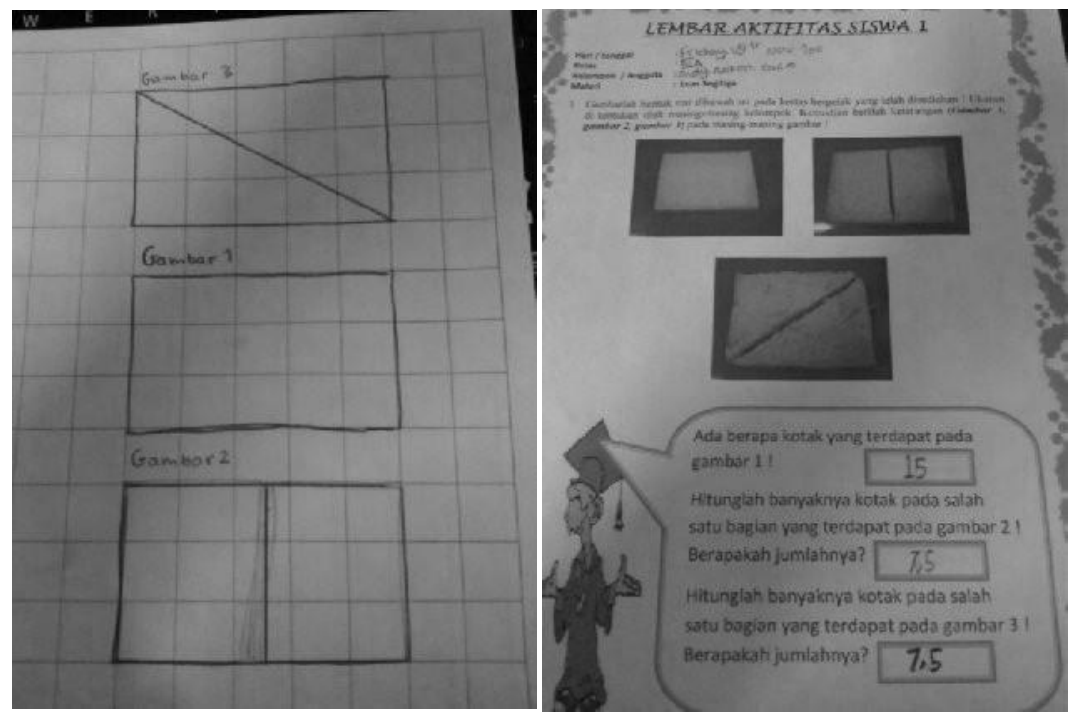

Selanjutnya guru bertanya bangaimana mereka dapat menghitung bahwa jumlah kotak pada gambar yang berbentuk segitiga berjumlah 7.5 kotak. Niken menjawab bahwa setiap kotak yang gambarnya lebih dari setengah kotak mereka menghitungnya menjadi 1 kotak (dibulatkan keatas), sedangkan apabila kotak tersebut tidak memenuhi 1 kotak, maka mereka tidak menghitungnya atau mengganggapnya sebagai 0 kotak. Sehingga mereka memperkirakan bahwa jumlah kotak yang membentuksegitiga tersebut juga adalah 7.5 kotak. Setelah itu guru meminta siswa yang lain untuk menyimpulkan apa hubungan antara luas roti yang berbentuk segitiga dan yang berbentuk persegi panjang. Dalam hal ini serentak siswa mengatakan bahwa luasnya sama. Gurupun bertanya kepada Amandamengama dia berkata demikian. Amanda berpendapat karena jumlah kotak yang membentuknya sama dan jumlah kotak tersebut merupakan luas dari bangun itu.

Pada aktivitas berikutnya, kebanyakan siswa dapat dengan mudah mencari rumus luas segitiga berdasarkan gambar potongan roti yang mereka buat. Pertama-tama, guru menanyakan kepada siswa berapakah luas roti sebelum dipotong menjadi dua bagian, 
berdasarkan gambar pada kertas berpetak. Maka siswa menjawab bervariasi sesuai dengan gambaryang mereka buat. Berdasarkan hasil diskusi pada aktivitas pertama maka diperoleh bahwa luas potongan roti yang berbentuk kubusdan yang berbentuk segitiga adalah sama besar. Sehingga luas dari setiap potongan roti tersebut adalah setengah dari luas roti mula-mula.

Dalam tahap ini, dapat dengan mudah menyimpulkan bahwa luas roti yang berbentuk segitiga adalah setengan dari luas roti awal yang berbentuk persegi panjang. Sehinga luas dari segitiga tersebut adalah $1 / 2$ PxL. Dalam tahap ini guru memfasilitasi siswa untuk mengingat kembali tentang unsur-unsur segitiga yang telah mereka pelajari di kelas 3. Sehingga siswa dapat menyimpulkan bahwa luas segitiga adalah $\frac{1}{2}$ Alas $\mathrm{x}$ Tinggi.

Berikut beberapa hasil pekerjaan siswa pada LKS 2:

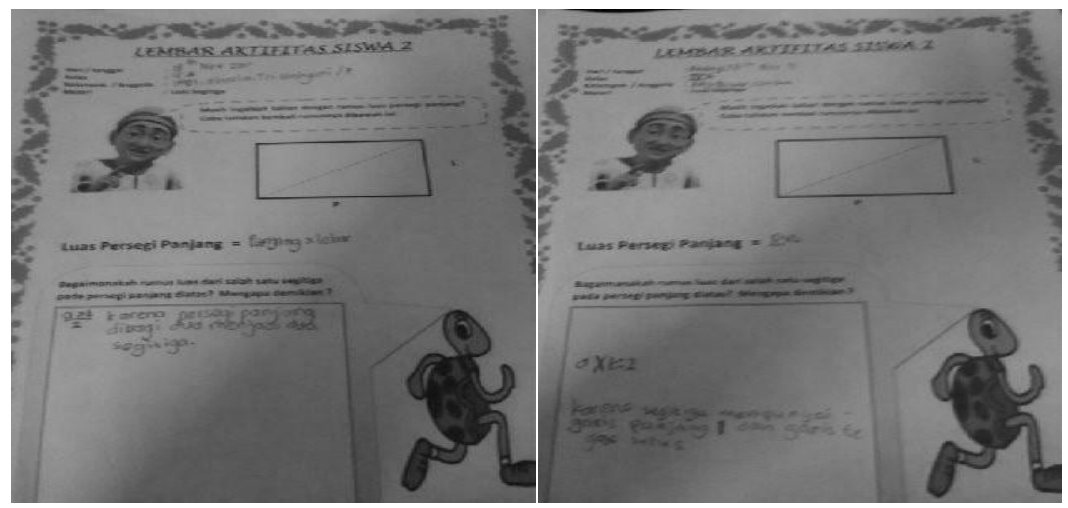

Gambar 8. Hasil Pekerjaan siswa pada LKS 2

Pada tahap ini, siswa telah dapat menemukan rumus luas segitiga dari pendekatan persegi dengan menggunakan konteks roti. Setelah itu guru mengembangkannya dengan memberikan soal kontekstual dalam mengimplementasikan rumus luas yang telah mereka peroleh.

Berdasarkan analisis hasil pekerjaansiswa, terdapat perbedaan persentasi keberhasilan dalam menyelesaikan permasalahan kontektual mengenai luas segitiga. Dimana sebanyak 75,37\% siswa mampu menyelesaikan soal yang diberikan dan hanya $24,63 \%$ siswa yang tidakmampu menyelesaikan soal yang diberikan. Hal ini mengindikasikan bahwa lebih dari separuh siswa sudah bisa 
mengetahui konsep luas segitiga dan bagaimana menggunakannya dalam menyelesaikan soal yang diberikan.

\section{Restropektif:}

Setelah kegiatan pembelajaran berakhir, guru dan observer berdiskusi untuk merefleksikan sejauhmana hasil implementasi dari desain pembelajaran yang telah dilaksanakan. Dari hasil diskusi antara observer dan guru, kamipun sungguh menyadari ada perbedaan kemampuan yang dimiliki masing-masing siswa sehingga harus membutuhkan penanganan yang berbeda pula. Ada siswa yang sudah mampu secara langsung menyelesaikan persoalan tanpa memerlukan bantuan, tetapi ada juga yang masih membutuhkan bimbingan dengan menggunakan alatperaga untuk membantu menyelesaian persoalanNamun secara keseluruhan proses pembelajaran kali ini boleh dikatakan berhasil dan dimana dapat menanamkan konsep pembagian kepada siswa dengan cara yang menyenangkan dan dekat dengan siswa.

\section{Penutup}

Dari hasil pelaksanaan desain riset ini, tidak bisa dipungkiri masih ada kekurangan yang harus dibenahi. Namun secara umum, seluruh siswa sangat bersemangat belajar matematika menggunakan pendekatan PMRI. Dengan pembelajaran berbasis PMRI kali ini siswa telah dapat mengetahui konsep luas segitigadan juga siswa telah mampu menyelesaikan soal-soal yang berkaitan dengan konsep luas segitiga.

\section{0) Output Design Research}

Masing-masing output atau luaran design research dapat diuraikan sebagai berikut :

\section{a) Intervensi}

Design research adalah pendekatan penelitian yang relevean dengan masalah praktis, yaitu menyelesaikan masalah-masalah praktis kependidikan yang belum memiliki solusi atau pedoman penyelesaian yang jelas atau mencari alternatif solusi atas masalah yang telah memiliki pedoman penyelesaian tapi terbukti tidak efektif. Untuk maksud tersebut, design research merancang dan mengembangkan suatu intervensi sebagai solusi yang dapat digunakan secara praktis untuk menyelesaikan 
masalahyang dimaksud. Intervensi ini dapat berupa program kegiatan, strategi atau kegiatan pembelajaran, materi atau prangkat pembelajaran, dan sistem atau produk pembelajaran lainnya.

\section{b) Teori Intervensi}

Selain menghasilkan produk berupa intervensi, di saat yang bersamaan Design Researchjuga menghasilkan teori intervensi, yaitu rasionalisasi atas pertanyaan bagaimana dan mengapa intervensi yang dikembangkan tersebut efektif dan efisienuntuk menyelesaikan masalah yang sedang dikaji. Untuk merumuskan teori intervensi dari sebuah proses pengembangan intervensi, pada tahap akhir dari setiap kegiatan design research dilakukan kegiatan refleksi secara sistematis terhadap data dan proses pengembangan yang telah dilakukan. Gravemeijer dan Cobb dalam Akker, dkk. (2006) menyebut proses ini dengan istilah retrospective analysis (analisis terhadap apa yang telah dilakukan di masa lalu).

\section{c) Pengembangan Profesional}

Dengan melibatkan berbagai pihak dalam kegiatan design research, pihak-pihak yang terlibat akan memiliki gambaran dan pemahaman mengenai masalah pendidikan dan alternatif penyelesiannya. Bagi peneliti pendidikan, misalnya, mereka akan lebih berpengalaman dan trampil dalam merumuskan masalah pendidikan yang kompleks melalui pendekatan saintifik (riset). Sedangkan bagi pendidik/guru/tutor yang terlibat, kegiatan ini akan membangkitkankesadaran dan inspirasi bagaimana riset dapat digunakan untuk meningkatkan profesionalisme mereka dalam menyelesaikan masalah dalam dunia kerja mereka. 
11) Format Penulisan Proposal Penelitian Design Reseacrh

\begin{tabular}{|l|}
\hline \multicolumn{1}{|c|}{ Format Penulisan Proposal Penelitian Design Reseacrh } \\
\hline HALAMAN JUDUL \\
\hline ABSTRAK \\
\hline PENGANTAR \\
\hline DAFTAR ISI \\
\hline DAFTAR GAMBAR \\
\hline DAFTAR TABEL \\
\hline BAB I. PENDAHULUAN \\
a. Latar Belakang Masalah \\
b. Rumusan Masalah \\
c. $\quad$ Tujuan Peneltian \\
d. $\quad$ Manfaat Pengembangan \\
\hline BAB II. TINJAUAN PUSTAKA \\
Kajian Teori \\
\hline BAB III. METODE PENELITIAN \\
a. Subjek,Waktu dan Lokasi Penelitian \\
b. Hypothetical Learning Trajectory (HLT) \\
c. $\quad$ Local Intruction Theory (LIT) \\
d. Teknik Pengumpulan data \\
e. $\quad$ Teknik Analisis Data \\
\hline BAB IV. HASIL DAN PEMBAHASAN \\
a. Deskripsi Data Hasil Penelitian \\
b. Deskripsi Hasil Penelitian \\
c. $\quad$ Pembahasan Kajian Dan Perbandingan Antara Hasil Pengolahan \\
BAB V. KESIMPULAN DAN SARAN \\
a. Kesimpulan \\
b. Saran \\
\hline DAFTAR PUSTAKA \\
\hline LAMPIRAN \\
\hline
\end{tabular}


Penelitian (Putra \& Vebrian, 2019) dengan judul DESAIN PEMBELAJARAN PMRI MATERI OPERASI HITUNG BILANGAN MENGGUNAKAN KONTEKS KERETAK GETAS LATIHAN.

Penggunaan konteks yang sering ditemui oleh siswa sangat baik diterapkan dalam proses pembelajaran matematika karena selain siswa belajar tentang materi matematika siswa akan mengenal lebih jauh tentang konteks tersebut. Selain itu, penggunaan konteks dalam pembelajaran matematika dapat membantu siswa mengimplementasikan matematika dalam menyelesaikan permasalahan konteks sehari-hari. Tujuan dari penelitian ini adalah untuk menghasilkan lintasan belajar materi operasi hitung bilangan menggunakan konteks keretak getas berbasis pendekatan PMRI. Metode penelitian ini merupakan penelitian design research, dugaan lintasan belajar (Hypothetical Learning Trajectory) dikembangkan dari serangkaian aktivitas pembelajaran materi operasi hitung bilangan menggunakan konteks keretak getas. Subjek penelitian ini adalah siswa kelas II SD STKIP Muhammadiyah Bangka Belitung yang berjumlah 24 siswa. Aktivitas pembelajaran yang dilakukan oleh siswa tentang operasi hitung bilangan yang meliputi operasi penjumlahan dan pengurangan bilangan. Hasil dari penelitian ini menunjukan bahwa melalui serangkaian aktivitas yang telah dilakukan dapat membantu siswa dalam mempelajari operasi hitung bilangan baik penjumlahan maupun pengurangan. 
Penelitian (Warsito et al., 2019) dengan judul Desain Pembelajaran Pecahan melalui Pendekatan Realistik di Kelas V.

Pecahan merupakan salah satu topik matematika yang hampir selalu menjadi masalah bagi siswa sekolah dasar (SD). Masalah tersebut muncul karena umumnya siswa tidak memahami konsep pecahan. Penelitian ini merupakan penelitian desain (design research) yang dirancang untuk memberikan suatu pertimbangan yang baik terhadap proses pembelajaran operasi pecahan melalui dugaan-dugaan yang dibangun dalam kerangka analisis hypotetical learning trajectory (HLT) yang kemudian diujicobakan dalam pembelajaran matematika realistik (PMR). PMR mendasari dari seluruh kegiatan penelitian desain riset. Hasil penelitian ini tergambar dari teori instruksional lokal (local instructional theory). Design research dilakukan dalam tiga tahap, yaitu desain pendahuluan, percobaan mengajar yang terdiri siklus 1 dan siklus 2, dan tahap ketiga analisis retrospektif. Penelitian melibatkan menggunakan sampel sebanyak 29 siswa kelas V di SDI Nurul Hasanah yang terdiri 4 orang siswa pada siklus satu dan 25 siswa pada siklus kedua. Hasil penelitian dapat menunjukan bahwa serangkaian kegiatan pembelajaran dengan PMR dapat membawa siswa dari situasi konkret menuju situasi yang lebih formal. Siswa mampu mengerjakan bilangan pecahan dari bentuk kontektual dengan disertai alasan.

\section{LATIHAN}

1. Tuliskan dengan menggunakan kalimat Anda sendiri kelebihan dan kekurangan dari masing-masing desain penelitian dibawah ini :

a. Penelitian eksperimen

b. Penelitian deskriptif

c. Penelitian dan Pengembangan

d. Desain riset

2. Berikan contoh masalah dalam pembelajaran matematika yang dapat diselesaikan dengan menggunakan jenis-jenis penelitian di atas!

\section{RANGKUMAN}

Desain penelitian mengacu pada rencana dan struktur penyelidikan yang digunakan untuk memperoleh bukti-bukti empiris. Desain menentukan validitas penelitian baik eksternal maupun internal. Validitas daeksternal mengacu pada kemampuan generalisasi hasil penelitian untuk diterapkan pada kelompok atau setting yang lebih luas, sedang validitas internal mengacu pada seberapa jauh apa yang diamati, diukur dan dianalisis sesuai dengan kenyataan.

Desain eksperimental untuk menguji pengaruh suatu variabel terhadap variabel yang lain dengan menggunakan manipulasi. Ada empat macam desain 
eksperimental, yaitu: pra eksperimen (tidak atau hanya sedikit memungkinkan pengendalian variabel). sejati (pengelompokan dan manipulasi dilakukan oleh peneliti), semu (manipulasi perlakuan dilakukan oleh peneliti, sedang pengelompokan subyek sudah ada lebih dulu), time-series (satu kelompok menerima dua macam perlakuan yang dimanipulasi secara berturut-turut), perlakuan tunggal (dua kelompok subyek menerima satu macam perlakuan yang dimanipulasi), dan faktorial (dua atau lebih variabel dimanipulasi secara simultan untuk menyelidiki pengaruh masing-masing terhadap variabel terikat).

Desain deskriptif digunakan untuk mendeskripsikan kenyataan yang telah terjadi. Ada 4 macam desain deskriptif, yaitu: survai, studi kasus, studi korelasi.

Penelitian pengembangan (R\&D) merupakan suatu pengkajian sistematik terhadap pendesainan, pengembangan dan evaluasi program, proses dan produk pembelajaran yang harus memenuhi kriteria validitas, kepraktisan dan efektivitas. Produk penelitian dan pengembangan dalam bidang pendidikan dapat berupa : model, media, peralatan, buku, modul, alat evaluasi dan perangkat pembelajaran; kurikulum, kebijakan sekolah dll. Ada dua model penelitian dan pengembangan sistem pembelajaran yaitu model 4D dan model ADDIE. Model 4D merupakan singkatan dari Define, Design, Development and Dissemination. Model ADDIE merupakan singkatan dari Analysis, Design, Development or Production, Implementation or Delivery and Evaluations.

Design Research merupakan pendekatan penelitian desain pembelajaran dirancang untuk merumuskan solusi atas kompleksitas masalah yang muncul dalam praktik pendidikan, dimana masalah tersebut belum memiliki solusi yang tepat atau belum ada pedoman yang jelas untuk menyelesaikan masalah tersebut. Kegiatan desain pembelajaran dipandang sebagai hal yang sama dengan kegiatan pengembangan pembelajaran, meskipun dalam tataran konseptual setiap model desain atau model pengembangan pembelajaran memiliki kekhususan dan penekanan tersendiri yang membedakan antara yang satu dengan yang lain. 


\section{TUGAS}

1. Memilih satu materi pelajaran matematika di tingkat SMP atau SMA, kemudian buatlah perangkat pembelajaran matematika (RPP, LKPD,THB) dari materi tersebut.

2. Membuat makalah dengan muatan Pendidikan Matematika Realistik (PMR) dimana bagian pokok yang harus ada Pendahuluan, Isi dan Kesimpulan.

3. Membuat Hypothetical Learning Trajectory (HLT) dengan materi matematika yang dipilih menggunakan pendekatan Pendidikan Matematika Realsitik (PMR).

4. Setelah Anda mempelajari bab ini, Anda ditugaskan merumuskan rancangan penelitian sesuai dengan hasil pengamatan pada Bab Masalah Penelitian (menyesuaikan dengan format penulisan masingmasing jenis penelitian). 


\section{BAB 7 SUBYEK PENELITIAN}

alah satu langkah yang harus dilakukan oleh seorang peneliti dalam mengumpulkan data adalah menentukan subyek penelitian. Subyek dapat diartikan sebagai individu yang ikut serta dalam penelitian. Dari subyek tersebut data didapat dan dikumpulkan. Sebagai suatu kelompok, subyek biasanya digunakan sebagai sampel. Sampel tersebut diambil dari sekelompok besar individu yang disebut populasi. Kebanyakan penelitian pendidikan tidak mungkin/perlu meneliti semua individu yang menjadi anggota populasi. Oleh karena tidak semua individu dalam populasi dilibatkan, maka perlu adanya proses pemilihan sampel dari populasi (sampling). Beberapa prosedur sampling yang biasanya digunakan dalam penelitian adalah sampling acak, sampling sistematis, sampling bertingkat, dan sampling klaster. Prosedur ini akan memudahkan peneliti dalam mencari teknik yang akan digunakan untuk membentuk sampel. Pada bab ini akan dibicarakan tentang pengertian populasi, jenis-jenis populasi, pengertian sampel, teknik-teknik sampling, dan ukuran sampel penelitian pendidikan. Kemampuan akhir yang diharapkan setelah mahasiswa mempelajari bab ini yaitu:

1. Menjelaskan populasi dan sampel penelitian

2. Memberikan contoh teknik pengambilan sampel

3. Menentukan populasi sebagai bahan dalam penyusunan proposal penelitian

4. Merumuskan sampel sebagai bahan dalam penyusunan proposal penelitian

\section{A. POPULASI DAN SAMPEL}

Terdapat perbedaan yang mendasar dalam pengertian populasi dan sampel pada penelitian kuantitatif dan kualitatif. Dalam penelitian kuantitatif, populasi diartikan sebagai wilayah generasi yang terdiri atas: obyek/subyek yang mempunyai kualitas dan karakteristik tertentu yang ditetapkan oleh peneliti untuk dipelajari dan kemudian ditarik kesimpulannya. Sedangkan sampel adalah sebagian dari populasi itu. Populasi itu misalnya penduduk di wilayah tertentu, jumlah pegawai pada organisasi, jumlah guru dan siswa di sekolah tertentu dan sebagainya.

Populasi adalah wilayah generalisasi yang terdiri atas objek/subjek yang mempunyai kuantitas dan karakteristik tertentu yang ditetapkan oleh peneliti untuk dipelajari dan kemudian ditarik kesimpulannya (Sugiyono, 2017). 
Menurut (Margono, 2004) populasi adalah seluruh data yang menjadi perhatian kita dalam suatu ruang lingkup dan waktu yang kita tentukan. Jadi populasi berhubungan dengan data, bukan manusianya. Kalau setiap manusia memberikan suatu data maka, maka banyaknya atau ukuran populasi akan sama dengan banyaknya manusia. Populasi adalah keseluruhan subjek penelitian (Arikunto, 2010).

Kerlinger (Furchan, 2004) menyatakan bahwa populasi merupakan semua anggota kelompok orang, kejadian, atau objek yang telah dirumuskan secara jelas. Nazir (2005) menyatakan bahwa populasi adalah kumpulan dari individu dengan kualitas serta ciri-ciri yang telah ditetapkan. Kualitas atau ciri tersebut dinamakan variabel. Sebuah populasi dengan jumlah individu tertentu dinamakan populasi finit sedangkan, jika jumlah individu dalam kelompok tidak mempunyai jumlah yang tetap, ataupun jumlahnya tidak terhingga, disebut populasi infinit. Misalnya, jumlah petani dalam sebuah desa adalah populasi finit. Sebaliknya, jumlah pelemparan mata dadu yang terus-menerus merupakan populasi infinit.

Dengan demikian, populasi bukan hanya orang, tetapi juga benda-benda alam yang lain. populasi juga bukan sekedar jumlah yang ada pada objek/subjek yang dipelajari, tetapi meliputi seluruh karakteristik/sifat yang dimiliki oleh objek atau subjek itu. Kaitannya dengan batasan tersebut, populasi dapat dibedakan berikut ini.

1. Populasi terbatas atau populasi terhingga, yakni populasi yang memiliki batas kuantitatif secara jelas karena memilki karakteristik yang terbatas. Misalnya 5.000.000 orang guru SMA pada awal tahun 1985, dengan karakteristik; masa kerja 2 tahun, lulusan program Strata 1, dan lain-lain.

2. Populasi tak terbatas atau populasi tak terhingga, yakni populasi yang tidak dapat ditemukan batas-batasnya, sehingga tidak dapat dinyatakan dalam bentuk jumlah secara kuantitatif. Misalnya guru d Indonesia, yang berarti jumlahnya harus dihitung sejak guru pertama ada sampai sekarang dan yang akan datang.

Dalam keadaan seperti itu jumlahnya tidak dapat dihitung, hanya dapat digambarkan suatu jumlah objek secara kualitas dengan karakteristik yang bersifat umum yaitu orang-orang, dahulu, sekarang dan yang akan menjadi guru. populasi seperti ini disebut juga parameter. Misalnya akan melakukan penelitian di sekolah X, maka sekolah X ini merupakan populasi. Sekolah X mempunyai sejumlah orang/subyek dan obyek yang lain. Hal ini mempuyai arti populasi dalam jumlah/kuantitats. Tetapi sekolah $\mathrm{X}$ juga mempuyai 
karakteristik orang-orangy, misalnya motivasi kerja, disiplin kerja, kepemimpinan, iklim organisasi, dan sebagainya. Populasi dalam hal ini mempunyai karakteristik. Satu orangpun dapat digunakan sebagai populasi, karena satu orang itu mempunayi karakteristik, misalnya gaya bicaranya, disiplin pribadi, hobi, cara bergaul, kepemimpinannya dan lain-lain.

Selain itu, menurut (Hasnunidah, 2017) populasi dapat dibedakan ke dalam hal berikut ini:

1. Populasi teoretis (teoritical population), yakni sejumlah populasi yang batas-batasnya ditetapkan secara kualitatif. Kemudian agar hasil penelitian berlaku juga bagi populasi yang lebih luas, maka ditetapkan terdiri dari guru; berumus 25 tahun sampai dengan 40 tahun, program S1, jalur skripsi, dan lain-lain.

2. Populasi yang tersedia (accessible population), yakni sejumlah populasi yang secara kuantitatif dapat dinyatakan dengan tegas. Misalnya, guru sebanyak 250 di kota Bandung terdiri dari guru yang memiliki karakteristik yang telah ditetapkan dalam populasi teoretis.

Persoalan populasi bagi suatu penelitian dapat juga dibedakan ke dalam beberapa sifat. Pertama, populasi yang bersifat homogen, yaitu populasi yang unsur-unsurnya memiliki sifat yang sama, sehingga tidak perlu dipersoalkan jumlahnya secara kuantitatif. Misalnya, seorang dokter yang akan melihat golongan darah seseorang, maka ia cukup mengambil setetes darah saja. Dokter itu tidak perlu satu botol, sebab setetes dan sebotol darah, hasilnya akan sama. Kedua, populasi yang bersifat heterogen, yaitu populasi yang unsur-unsurnya memiliki sifat atau keadaan yang bervariasi sehingga perlu ditetapkan batas-batasnya, baik secara kualitatif maupun secara kuantitatif. Penelitian yang objeknya manusia atau gejala-gejala dalam kehidupan manusia biasanya menghadapi populasi yang heterogen.

Sampel adalah bagian dari jumlah dan karakteristik yang dimiliki oleh populasi tersebut. Bila populasi benar, dan peneliti tidak mungkin mempelajari semua yang ada pada populasi, misalnya karena keterbatasan dana, tenaga dan waktu, maka peneliti dapat menggunakan sampel yang diambil dari populasi itu. Apa yang akan dipelaajari dari populasi itu, kesimpulannya akan di berlakukan untuk populasi. Untuk itu sampel yang diambil dari populasi haru betul-betul mewakili (representatif).

Bila sampel tidak representatif, maka ibarat orang buta disuruh menyimpulkan karakteristik gajah. Perhatikan gambar 7.1. Berdasarkan gambar tersebut terlihat bahwa, orang pertama memegang telinga gajah, maka 
ia menyimpulkan gajah itu seperti kipas. Orang kedua memegang badan gajah, maka ia menyimpulkan gajah itu seperti tembok besar. Orang ketiga memegang ekornya, maka ia menyimpulkan gajah itu kecil seperti seutas tali. Orang keempat memegang kaki gajah, maka ia menyimpulkan gajah seperti sebatang pohon. Begitulah kalau sampel yang dipilih tidak representatif, maka ibarat 4 orang yang ditutup matanya memegang gajah, mereka tidak mampu memilih sampel yang reprsentatif. sehingga membuat kesimpulan yang salah tentang gajah.

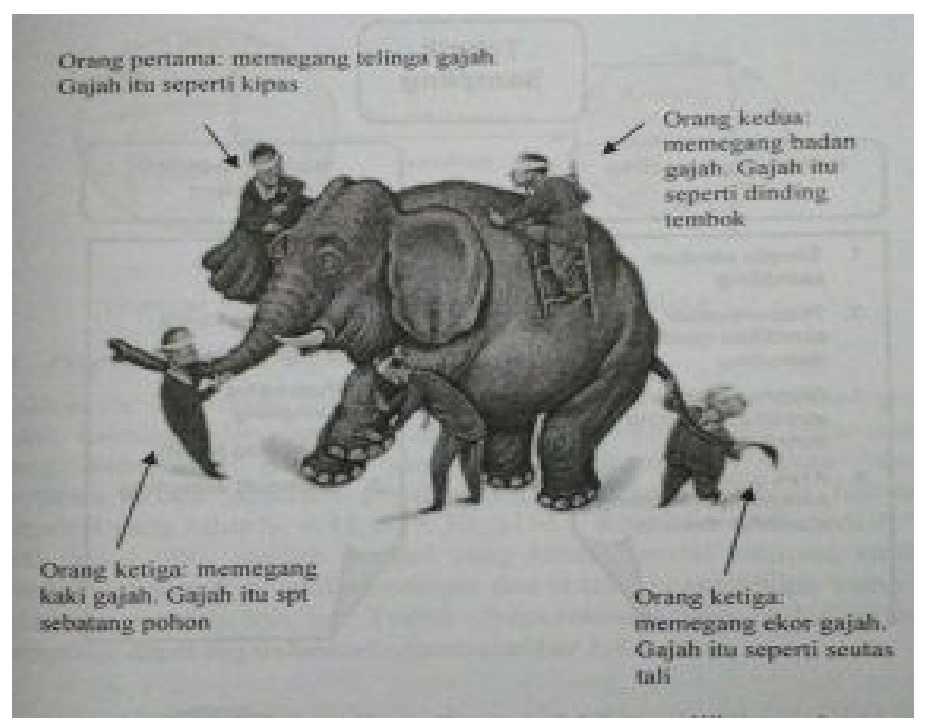

Gambar 7.1. Empat orang yang memilih sampel yang salah tentang Gajah, sehingga Kesimpulan juga salah (Sugiyono, 2017)

Pada penelitian kualitatif tidak menggunakan istilah populasi, tetapi oleh Spradley dinamakan social situation atau situasi sosial yang terdiri atas tiga elemen yaitu: tempat (place), pelaku (actors), dan ativitas (activity) yaitu berinteraksi secara sinegris. Situasi sosial tersebut dapat dinyatakan sebagai obyek penelitian yang ingin dipahami secara lebih mendalam apa yang terjadi didalamnya. Pada sistuasi sosial atau obyek penelitian ini, penelitian ini dapat mengamati secara mendalam aktivitas (activity) orang-orang (actors) yang ada pada tempat ( place) tertentu. Situasinya dapat dilihat pada gambar 7.2. 


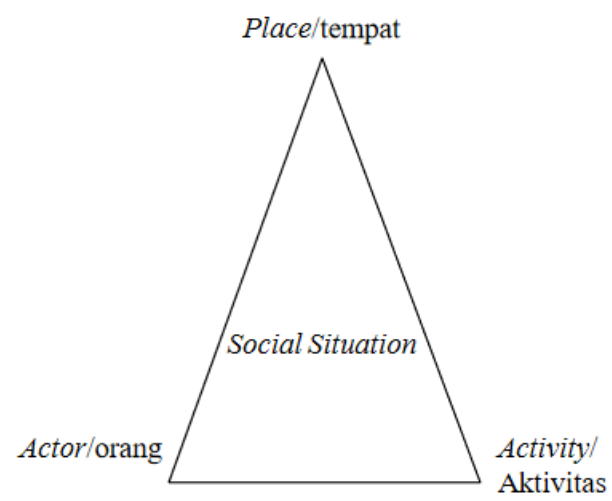

Gambar 7.3. Situasi sosial (Sosial situation) (Sugiyono, 2017)

Penelitian kualitatif berangkat dari kasus yang ada pada situasi sosial tertentu dan hasil kajiannya tidak akan diberlakukan populasi, tetapi ditransferkan ke tempat lain pada situasi sosial yang memiliki kesamaan dengan situasi sosial pada kasus yang dipelajari. Sampel dalam penelitian kualitatif bukan dinamakan responden, tetapi narasumer, atau partisipan, informan, teman dan guru dalam penelitian. Sampel penelitian disebut sampel konstruktif, karena dengan sumber data dari sampel itu dapat dikonstruksikan fenomena yang smula masih belum jelas. Sampel dalam penelitian kualitatif, juga bukan disebut sampel statistik, tetapi sampel teoritis, karena tujuan penelitian kualitatif adalah untuk menghasilkan teori.

Berdasarkan hal di atas, maka model penelitian kuantitatif dan kualitatif dapat ditunjukan pada gambar 7.4. a dan 7.4.b.

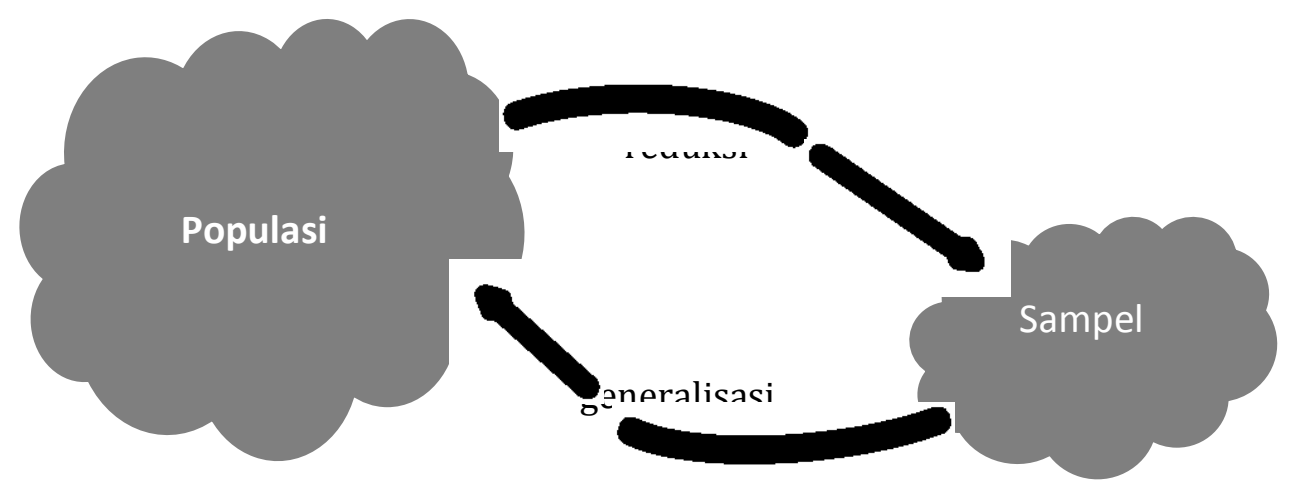

Gambar 7.4.a. Model generalisasi penelitian Kualitatif. Sampel representatif, hasilnya digeneralisasikan ke populasi (Sugiyono, 2017) 
Pada penelitian kualitatif, peneliti memasuki sittuasi sosial tertentu, yang dapat berupa lembaga pendidikan tertentu, melakukan observasi dan wawancara kepada orang-orang yang dipandang tahu tentang situasi sosial tersebut. Penentuan sumber data pada orang yang diwawancarai dilakukan secara purposive, yaitu dipilih dengan pertimbangan dan tujuan tertentu. Hasil penelitian tidak akan digeneralisasikan ke populasi karena pengambilan sampel tidak diambil secara random. Hasil penelitian dengan metode penelitian kualitatif hanya berlaku untuk kasus situasi sosial tersebut. Hasil penelitian tersebut dapat ditransferkan atau diterapkan ke situasi sosial (tempat lain), apabila situasi sosial tersebut memiliki kemiripan atau kesamaan dengan situasi sosial yang diteliti.

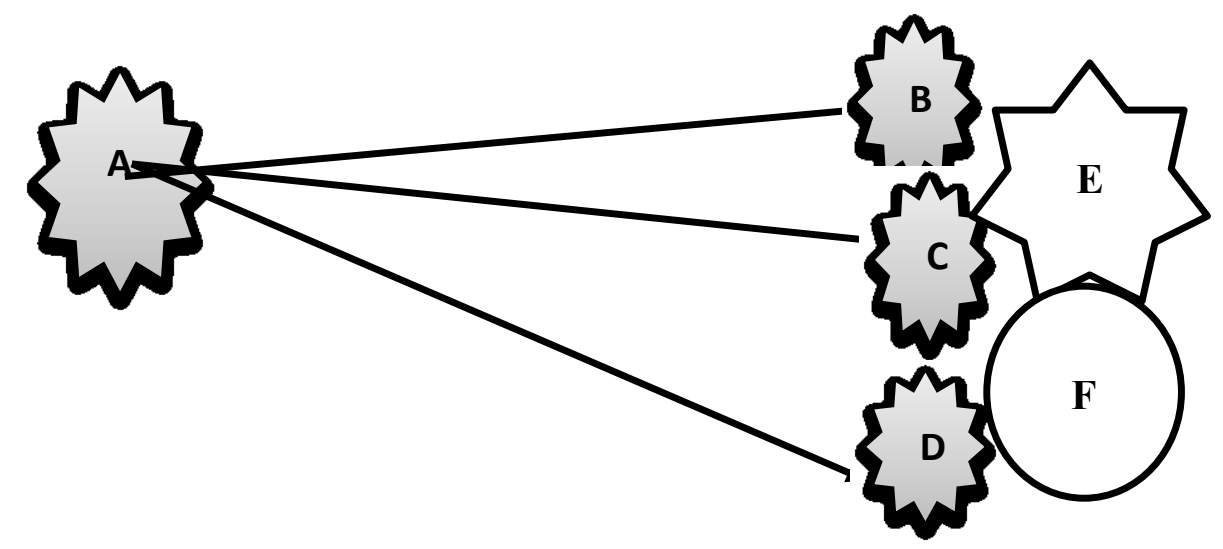

Gambar 7.4.b. Model Generalisasi penelitian Kualitatif. Sampel Purposive, hasi dari A dapat ditransferkan hanya ke B, C, D. (Sugiyono, 2017)

\section{B. TEKNIK SAMPLING}

Teknik sampling adalah merupakan teknik pengambilan sampel. Sampel adalah sebagai bagian dari populasi yang diambil dengan menggunakan caracara tertentu. Dalam beberapa penelitian seringkali jumlah subyek dalam sampel sama dengan jumlah yang ada dalam populasi. Dalam hal ini tidak ada pemilihan subyek dari /kelompok yang lebih besar. Penelitian ini dilakukan terutama bila peneliti ingin mengetahui atau mempelajari sesuatu yang hasilnya akan diberlakukan untuk kelompok subyek yang dilibatkan secara langsung saja, tanpa bermaksud memberlakukannya untuk kelompok yang lebih besar. Seorang guru sejarah, misalnya ingin mengubah teknik mengajarnya yang sesuai dengan minat siswa dalam suatu kelas tertentu. Oleh karena itu dia melakukan penelitian lebih dahulu terhadap minat siswa di kelasnya dengan melibatkan semua siswa yang ada. Karena sampel tidak dipilih dari populasi, maka hasilnya hanya berlaku untuk mendeskripsikan 
siswa yang ada dalam kelas tersebut, bukan untuk kelompok siswa yang lebih besar.

Akan tetapi, dalam kebanyakan penelitian, karena adanya berbagai alasan (misalnya efisiensi tenaga, waktu, dan biaya) tidak selalu mungkin atau perlu untuk melibatkan semua individu yang ada dalam kelompok sebagai subyek penelitian. Dengan demikian, penelitian tersebut hanya melibatkan sebagian individu (sampel) yang dipilih dari kelompoknya (populasi) untuk menjadi subyek. Hasil penelitian terhadap kelompok individu yang menjadi sampel tersebut juga berlaku bagi individu lain yang termasuk dalam kelompok populasi. Oleh karena tidak semua individu dalam populasi dilibatkan, maka perlu adanya proses pemilihan sampel dari populasi. Pemilihan sampel disebut juga sampling. Ada beberapa jenis sampling, diantaranya sebagai berikut:

\section{1) Probability Sampling (Random Sample)}

Probability sampling adalah metode pengambilan sampel secara random atau acak. Dengan cara pengambilan sampel ini.

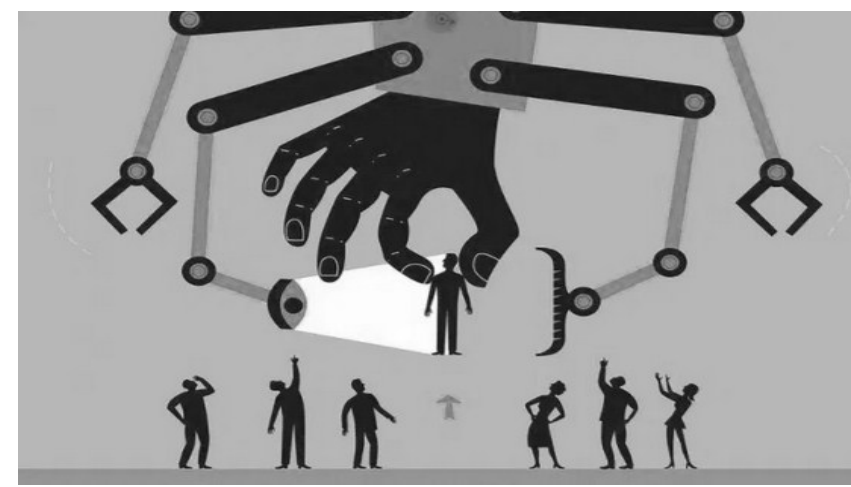

Gambar 7.5. Probability sampling

Seluruh anggota populasi diasumsikan memiliki peluang yang sama untuk terpilih menjadi sampel penelitian. Dibawah ini disajikan macam-macam probability samplingyaitu:

\section{a) Simple Random Sampling}

Dikatakan simple (sederhana) karena pengambilan anggota sampel dari populasi dilakukan secara acak tanpa memperhatikan strata yang ada dalam populasi itu. Cara demikian dilakukan bila anggota populasi dianggap homogen. Pengambilan sampel acak sederhana dapat dilakukan dengan cara undian, memilih bilangan dari daftar bilangan secara acak, dsb. Teknik ini ditunjukan pada gambar dibawah ini. 


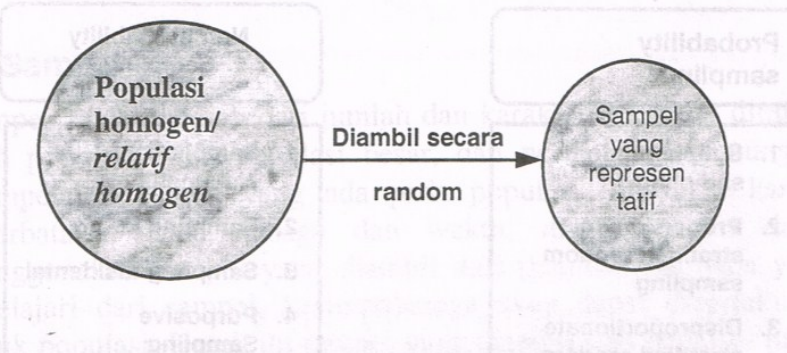

Gambar 7.6. Teknik simple Random sampling

\section{b) Proportionate Stratified Random Sampling}

Teknik ini digunakan bila populasi mempunyai anggota/unsur yang tidak homogen dan berstrata secara proporsional. Suatu organisasi yang mempunyai pegawai dari latar belakang pendidikan yang berstrata, maka populasi pegawai itu berstrata. Misalnya jumlah pegawai yang lulus $\mathrm{Si}=45,82=30$, $\mathrm{STM}=800$, $\mathrm{ST}=900$, SMEA $=400, \mathrm{SD}=300$. Jumlah sampel yang harus diambil meliputi strata pendidikan tersebut. Jumlah sampel dan teknik pengambilan sampel diberikan setelah bab ini. Teknik ini ditunjukan pada gambar dibawah ini.

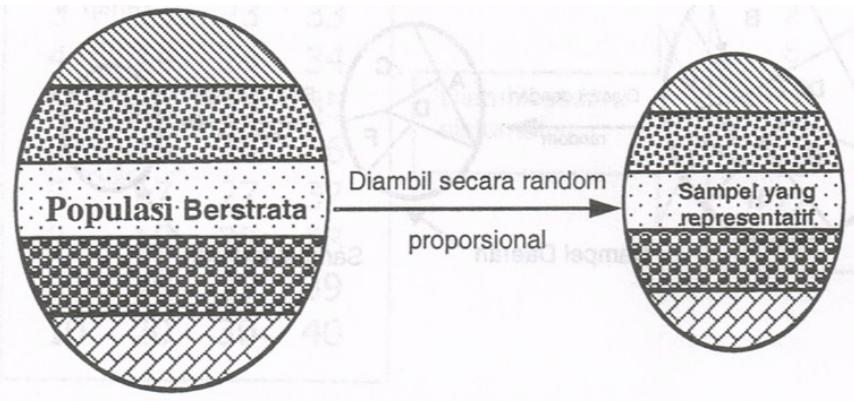

Gambar 7.8. Teknik Stratified Random Sampling

\section{c) Disproportionate Stratified Random Sampling}

Teknik ini digunakan untuk menentukan jumlah sampel, bila populasi berstrata tetapi kurang proporsional. Misalnya pegawai dari unit kerja tertentu mempunyai; 3 orang lulusan 83, 4 orang lulusan S2, 90 orang Si ,800 orang SMU, 700 orang SMP, maka tiga orang lulusan 83 dan empat orang 82 itu diambil semuanya sebagai sampel, karena dua kelompok ini terlalu kecil bila dibandingkan dengan kelompok Si, SMU, dan SMP. 


\section{d) Cluster Sampling (Area Sampling)}

Teknik sampling daerah digunakan untuk menentukan sampel bila obyek yang akan diteliti atau sumber data sangat luas, misal penduduk dari suatu negara, propinsi atau kabupaten. Untuk menentukan penduduk mana yang akan dijadikan sumber data, maka pengambilan sampel ditetapkan secara bertahap dari wilayah yang luas (negara) sampai ke wilayah terkecil (kabupaten). Setelah terpilih sampel terkecil, kemudian baru dipilih sampel secara acak.

Misalnya di Indonesia terdapat 30 propinsi, dan sampelnya akan menggunakan 15 propinsi, maka pengambilan 15 propinsi itu dilakukan secara random. Tetapi perlu diingat, karena propinsipropinsi di Indonesia itu berstrata (tidak sama) maka pengambilan sampelnya perlu menggunakan stratified random sampling. Propinsi di Indonesia ada yang pendudukanya padat, ada yang tidak; ada yang mempunyai hutan banyak ada yang tidak, ada yang kaya bahan tambang ada yang tidak. Karakteristik semacam ini perlu diperhatikan sehingga pengambilan sampel menurut strata populasi itu dapat ditetapkan. Teknik sampling daerah ini sering digunakan melalui dua tahap, yaitu tahap pertama menentukan sampel daerah, dan tahap berikutnya menentukan orang-orang yang ada pada daerah itu secara sampling juga. Teknik ini ditunjukan pada gambar dibawah ini.

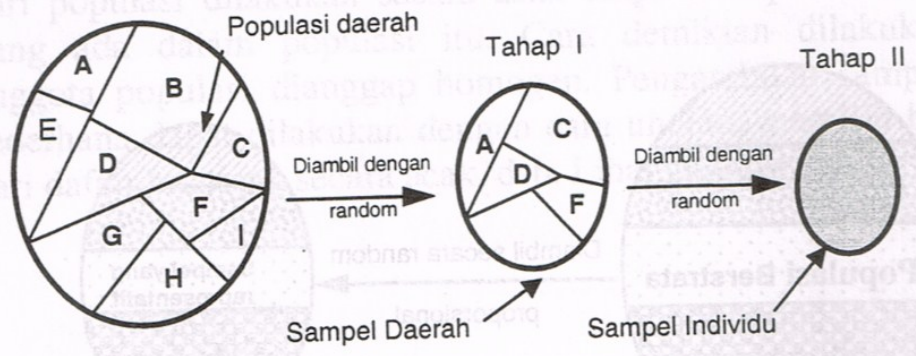

Gambar 7.9. Teknik Cluster Sampling 


\section{2) Non-Probability Sampling (Non-Random Sample)}

Non-Probability Sampling teknik pengambilan sampel yang tidak memberi peluang/kesempatan sama bagi setiap unsur atau anggota populasi untuk dipilih menjadi sampel.

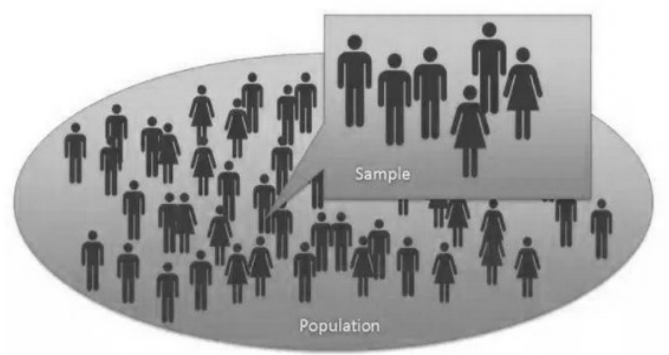

Dibawah ini disajikan macam-macam non-Probability Samplingyaitu:

\section{a) Sampling sistematis}

Sampling sistematis adalah teknik penentuan sampel berdasarkan urutan dari anggota populasi yang telah diberi nomor urut. Misalnya anggota populasi yang terdiri dari 100 orang. Dari semua anggota diberi nomor urut, yaitu nomor 1 sampai dengan nomor 100. Pengambilan sampel dapat dilakukan dengan nomor ganjil saja, genap saja, atau kelipatan dari bilangan tertentu, misalnya kelipatan dari bilangan lima. Untuk itu, yang diambil sebagai sampel adalah 5, 10, 15, 20 dan seterusnya sampai 100. Lihat gambar berikut.

\begin{tabular}{|c|c|c|c|c|c|c|}
\hline \multicolumn{4}{|c|}{ Populasi } & & \multicolumn{2}{|r|}{ Sampel } \\
\hline 1 & 1 & 31 & 31 & & 3 & 24 \\
\hline 2 & 2 & 32 & 32 & & 6 & 27 \\
\hline 3 & 3 & 33 & 33 & & 9 & 30 \\
\hline 4 & 4 & 34 & 34 & & 12 & 33 \\
\hline 5 & 5 & 35 & 35 & Diambil secara & 15 & 36 \\
\hline 6 & 6 & 36 & 36 & sistematis & 18 & 39 \\
\hline 7 & 7 & 37 & 37 & & 21 & \\
\hline 8 & 8 & 38 & 38 & & & \\
\hline 9 & 9 & 39 & 39 & & & \\
\hline 10 & 10 & 40 & 40 & & & \\
\hline
\end{tabular}

Gambar 7.10. Sampling Sistematis. No populasi ketipatan tiga yang diambil $(3,6,9$ dst $)$ 


\section{b) Sampling Kuota}

Sampling Kuota adalah teknik untuk menentukan sampel dan populasi yang mempunyai ciri-ciri tertentu sampai jumlah (kuota) yang diinginkan. Sebagai contoh, akan melakukan penelitian tentang pendapat masyarakat terhadap pelayanan masyarakat dalam urusan Ijin Mendirikan Bangun (IMB). Jumlah sampel yang ditentukan 500 orang tersebut, maka penelitian dipandang belum selesai, karena belum memenuhi kuota yang ditentukan.

Bila pengumpulan data dilakukan secara kelompok yang terdiri atas 5 orang pengumpul data, maka setiap anggota kelompok harus dapat menghubungi 100 orang anggota sampel, atau 5 orang tersebut harus dapat mencari data dari 500 orang anggota sampel.

c) Sampling Insidential

Sampling Insidential adalah teknik penentuan sampel berdasarkan kebetulan, yaitu siapa sapa yang secara kebetulan insidential bertemu dengan peneliti dapat digunakan sebagai sampel, bila dipandang orang yang kebetulan ditemui itu cocok sebagai sumber data.

\section{d) Sampling Purposive}

Sampling Purposive adalah teknik penentuan sampel dengan pertimbangan tertentu. Misalnya akan melakukan penelitian tentang kualitas makan, maka sampel sumber datanya adalah orang yang ahli makanan, atau penelitian tentang kondisi politik di suatu daerah, maka sampel sumber datanya adalah ahli politik. Sampel ini lebih cocok digunakan untuk penelitian kualitatif, atau penelitian-penelitian yang tidak melakukan generalisasi.

e) Sampling Jenuh

Sampling Jenuh adalah teknik penentuan sampel bila semua anggota populasi digunakan sebagai sampel. Hal ini sering dilakukan bila jumlah populasi relatif kecil, kurang dari 30 orang, atau penelitian yang ingin membuat generalisasi dengan kesalahan yang sangat kecil. Istilah lain sampel jenuh adalah sensus, dimana semua anggota populasi dijadikan sampel.

\section{f) Snowball Sampling}

Snowball sampling adalah teknik penentuan sampel yang mulamula jumlahnya kecil, kemudian membesar. Ibarat bola salju yang menggelinding yang lama-lama menjadi besar. Dalam penentuan sampel, pertama-tama dipilih satu atau dua orang, tetapi karena 
dengan dua orang ini masih belum merasa lengkan terhadap data yang diberikan, maka peneliti mencari orang lain yang dipandang lebih tahu dan dapat melengkapi data yang diberikan oleh dua orang sebelumnya. Begitu seterusnya, sehingga jumlah sampel semakin banyak. Teknik pengambilan sampel ditunjukan pada gambar 7.11.

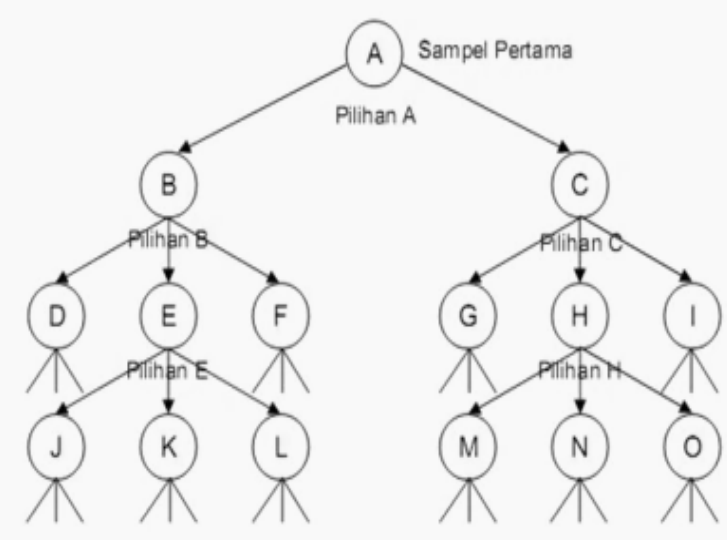

Gambar 7.11. Snowball Sampling

Penentuan sampel dalam penelitian kualitatif dilakukan saat peneliti mulai memasuki lapangan dan selama penelitian berlangsung ukuran sampel bertambah (emergent sampling design). Caranya yaitu, peneliti memilih orang tertentu yang dipertimbangkan akan memberikan data yang diperlukan; selanjutnya berdasarkan data atau informasi yang diperoleh dari sampel sebelumnya itu, peneliti dapat menetapkan sampel lainnya yang dipertimbangkan akan memberikan data lebih lengkap. Praktek seperti inilah yang disebut sebagai "serial selection of sample units" (Lincoln dan Guba, 1985), atau dalam kata-kata Bogdan dan Biklen (1982) dinamakan "snowball sampling technique". Unit sampel yang dipilih makin lama makin banyak dan terarah sejalan dengan makin terarahnya fokus penelitian. Proses ini dinamakan Bogdan dan Biklen (1982) sebagai "continuous adjustment of 'focusing' of the sample".

Dalam proses penentuan sampel seperti dijelaskan di atas, berapa besar sampel tidak dapat ditentukan sebelumnya. Dalam sampling purposive besar sampel ditentukan oleh pertimbangan informasi. Seperti ditegaskan oleh Lincoln dan Guba (1985) bahwa "If the purpose is to maximize information, then sampling is terminated when no new information is forth-coming from 
newly sampled units; this redundancy is the primary criterion". Dalam hubungan ini Sugiyono (2008) menjelaskan bahwa penentuan unit sampel (responden) dianggap telah memadai apabila telah sampai kepada taraf "redundancy" (datanya telah jenuh, ditambah sampel lagi tidak memberikan informasi yang baru), artinya bahwa dengan menggunakan responden selanjutnya boleh dikatakan tidak lagi diperoleh tambahan informasi baru yang berarti.

Teknik pengambilan sampel sumber data dalam penelitian kualitatif yang bersifat purposive dan snowball itu dapat digambarkan seperti Gambar 7.12 berikut.

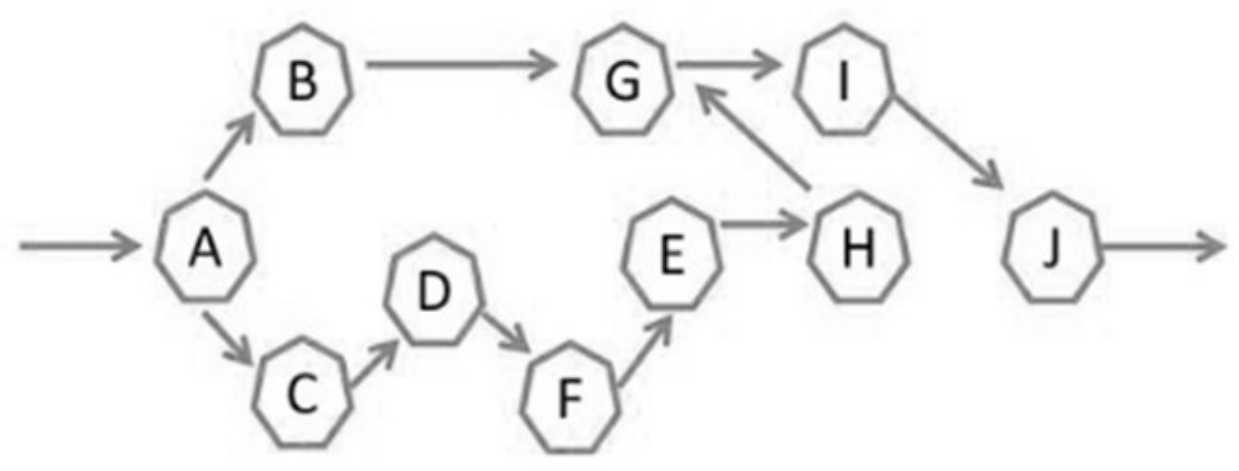

Gambar 7.12. Proses pengambilan sampel sumber data dalam penelitian Kualitatif, Purposive dan Snowball

Berdasarkan di atas dapat dijelaskan sebagai berikut. Dalam proposal penelitian, peneliti telah merencanakan A sebagai orang pertama sebagai sumber data. Informan awal ini sebaiknya dipilih orang yang bisa membukakan pintu untuk mengenali keseluruhan medan secara luas (mereka yang tergolong penjaga gawang dan informan yang cerdas). Selanjutnya oleh A peneliti disarankan menemui ke B dan C. Jika dari B dan C, peneliti belum memperoleh data yang lengkap, maka peneliti menemui D dan G. Kalau dari D dan $G$ peneliti juga masih belum memperoleh data yang akurat, maka peneliti pergi ke F kemudian ke E, selanjutnya ke H, ke I dan terakhir ke J. Setelah sampai J data sudah jenuh, sehingga sampel sumber data sudah mencukupi, dan tidak perlu menambah sampel yang baru.

Faisal (1990) dengan mengutip pendapat Spradley mengemukakan bahwa, situasi sosial untuk sampel awal sangat disarankan suatu situasi sosial yang di dalamnya menjadi semacam muara dari banyak domain lainnya sehingg 
sampel sebagai sumber data atau sebagai informan sebaiknya yang memenuhi kriteria sebagai berikut.

1. Mereka yang menguasai atau memahami sesuatu melalui proses enkulturasi, sehingga sesuatu itu bukan sekedar diketahui, tetapi juga dihayatinya.

2. Mereka yang tergolong masih sedang berkecimpung atau terlibat pada kegiatan yang tengah diteliti.

3. Mereka yang mempunyai waktu yang memadai untuk dimintai informasi.

4. Mereka yang tidak cenderung menyampaikan informasi hasil "kemasannya" sendiri.

5. Mereka yang pada mulanya tergolong "cukup asing" dengan peneliti sehingga lebih menggairahkan untuk dijadikan semacam guru atau nara sumber.

6. Kapankan penambahan sampel ini berhenti? Penambahan sampel itu dihentikan, manakala datanya sudah jenuh. Dari berbagai informan, baik yang lama maupun yang baru, tidak memberikan data baru lagi.

Bila pemilihan sampel atau informan benar-benar jatuh pada subyek yang benar-benar menguasai situasi sosial yang diteliti (obyek), maka merupakan keuntungan bagi peneliti, karena tidak memerlukan banyak sampel lagi, sehingga penelitian cepat selesai. Hal yang menjadi kepedulian bagi peneliti kualitatif adalah "tuntasnya" perolehan informasi dengan keragaman variasi yang ada, bukan banyaknya sampel sumber data.

Contoh:

Seorang peneliti, ingin memasukan gaya belajar anak yang berbakat di Sekolah Dasar. Berdasarkan hal tersebut maka langkah-langkah penentuan sampel sumber data adalah sebagai berikut.

1. Melakukan penjelajahan umum berbagai sekolah SD untuk mencari adakah siswa yang berbakat. Penjelajahan dengan memilih kepala sekolah dan guru, serta dokumen sebagai sumber data awal, untuk mengetahui ada tidaknya anak berbakat apa pada SD yang dipimpinnya. (sampel sumber data dipilih kepala sekolah, guru, dokumen).

2. Setelah ada informasi dari kepala sekolah, guru, dan dokumentasi nilainilai pelajaran, selanjutnya dapat diketahui jumlah anak berbakat pada setiap kelas, misalnya setiap kelas ditemukan ada dua siswa yang berbakat. Dengan demikian untuk satu SD ada 12 siswa yang berbakat 
(2 x 6 kelas). Di sini sampel sumbe data kepala sekolah, guru dan dokumentasi.

3. Berdasarkan 12 siswa tersebut, selanjutnya dapat diidentifikasikan nilai rapor dari berbagai pelajaran, ranking di kelas, penghargaan yang telah diperoleh, bakan spesifik yang dimiliki, latar belakang sosial dan ekonomi keluarga dan orang tua siswa (sumber data siswa dan dokumentasi).

4. Mulai melakukan penelitian terhadap murid-murid yang terpilih tersebut dengan sampel sumber data pesera didik yang bersangkutan dalam berbagai aktivitasnya, guru-guru, orang tua dan teman. Pengumpulan dilakukan secara triangulasi.

\section{UKURAN SAMPEL}

Menentukan ukuran sampel penelitian merupakan bagian terpenting yang harus dilakukan peneliti sebelum melakukan penelitian guna menghasilkan data yang memadai untuk menjawab pertanyaan penelitian. Tidak ada aturan yang baku berapa banyak agar sampel dapat mewakili populasi. Akan tetapi, semakin besar sampel semakin besar kemungkinan mencerminkan populasi. Dalam menentukan jumlah sampel, seorang peneliti harus memperhatikan beberapa hal:

\section{1) Jenis penelitian}

Penelitian korelasional harus memiliki sedikitnya 30 subyek, pendidikan komparatif membutuhkan sekurangnya 15 subyek untuk masing-masing kelompok. Pada penelitian eksperimen yang dikontrol secara ketat, 8 sampai 10 subyek dalam masing-masing kelompok dianggap memadai untuk mendapatkan hasil yang akurat. Dalam penelitian yang menggunakan survey, harus ada sekitar 100 subyek pada masing-masing subgroup utama yang dikaji dan 20 sampai 50 subyek dalam subgroup pelengkap.

\section{2) Hipotesis}

Bila peneliti ingin mendapatkan hasil berupa perbedaan kecil atau hubungan yang sangat kuat, sebaiknya menggunakan sampel dalam jumlah besar karena subyek yang kecil umumnya sulit untuk mendeteksi adanya hubungan perbedaan yang kecil secara signifikan. 


\section{3) Keterbatasan dana}

Biaya penelitian akan membatasi jumlah subyek yang dijadikan sampel. Oleh karenanya jumlah sampel yang diperlukan harus disesuaikan dengan dana yang tersedia.

4) Pentingnya hasil

Dalam penelitian eksploratif, jumlah sampel yang kecil dapat diterima karena peneliti dapat mentolerir kesalahan yang relatif agak besar dari hasil yang diperoleh. Dalam penelitian yang hasilnya akan dijadikan dasar suatu kebijaksanaan, peneliti lebih baik menggunakan subyek yang besar, karena kesalahan yang mungkin timbul dapat ditekan seminimal mungkin.

5) Jumlah variabel dalam penelitian

Sampel yang lebih besar diperlukan dalam penelitian yang memiliki banyak variabel bebas atau terikat, atau memiliki banyak variabel yang tidak bisa dikontrol.

6) Metode pengumpulan data

Bila metode pengumpulan informasi tidak memiliki akurasi yang tinggi atau konsisten, sampel yang lebih besar akan diperlukan untuk mengimbangi kesalahan yang muncul dari pengumpulan data.

7) Akurasi yang dibutuhkan

Derajat kepercayaan akan meningkat bila jumlah subyek yang dilibatkan semakin besar.

8) Ukuran populasi

Jika jumlah individu dalam populasi semakin besar, peneliti dapat mengambil persentase yang lebih kecil untuk dijadikan sampel penelitian.

\section{PENETAPAN UKURAN SAMPEL}

Penetapan ukuran sampel tergantung pada karakteristik populasinya. Populasi pada kumpulan benda, darah, sirup, makanan, obat, bahan makanan yang berasal dari sumber yang sama bersifat homogen. Jumlah sampel untuk populasi yang bersifat homogen tidak berpengaruh pada kesimpulan sehingga meskipun jumlah sampel yang diambil hanya sedikit, hasil penyelidikan dapat memperoleh kesimpulan yang sama. Sebagai contoh: seorang peneliti mengambil hanya $1 \mathrm{cc}$ darah untuk menge- tahui kadar kolesterol pada tubuh A. 
Jumlah darah tersebut sudah mewakili meskipun peneliti hanya mengambil $1 \mathrm{cc}$ karena darah bersifat homogen.

Populasi pada manusia cenderung bersifat heterogen dan tersebar mendekati distribusi normal. Besar sampel dari populasi yang sebarannya berdistribusi normal diambil secara proporsional. Untuk populasi seperti ini, besar proporsi ukuran sampling dari populasinya berbanding terbalik. Semakin besar jumlah sampel dari jumlah populasinya maka semakin kecil peluang kesalahan kesimpulan hasil penelitian yang akan digeneral- isasi. Sebaliknya, semakin kecil jumlah sampel dari populasinya, maka semakin besar kesalahan kesimpulan hasil penelitian yang akan digener- alisasi. Ukuran sampel yang harus diambil tergantung pada tingkat keteli- tian atau kesalahan yang dikehendaki. Tingkat ketelitian yang dikehenda- ki sering tergantung pada sumber dana, waktu dan tenaga yang tersedia.

Penetapan ukuran sampel dapat mengacu dari berbagai referensi. Masingmasing referensi menetapkan ukuran sampel dengan proporsi yang berbeda. Berikut ini ada beberapa cara penetapan ukuran sampel (Mulyatiningsih, 2011) yang diambil dari berbagai referensi, misalnya:

\section{Issac dan Michael}

Isaac dan Michael (1984) telah menghitung ukuran sampling dari jumlah populasi 10 sampai 1.000.000. Hasil penghitungan ukuran sampel tersebut telah dirangkum pada tabel 7.1. Ukuran sampel ditetapkan pada taraf kesalahan 1\%. 5\% dan 10\%. Sebagai contoh, apabila terdapat jumlah populasi (N) sebanyak 100, pada taraf kesalahan 1\% diperlukan jumlah sampel (s) sebanyak 87 sedangkan pada taraf kesalahan 5\% diperlukan jumlah sampel sebanyak 78 (lihat tabel 7.1). 
Tabel 7.1. Penentuan Ukuran Sampel Menurut Isaac dan Michael

\begin{tabular}{|c|c|c|c|c|c|c|c|}
\hline \multirow[b]{2}{*}{$\mathrm{N}$} & \multicolumn{3}{|c|}{ Siginifikasi } & \multirow[b]{2}{*}{$\mathrm{N}$} & \multicolumn{3}{|c|}{ Siginifikasi } \\
\hline & $1 \%$ & $5 \%$ & $10 \%$ & & $1 \%$ & $5 \%$ & $10 \%$ \\
\hline 10 & 10 & 10 & 10 & 280 & 197 & 155 & 138 \\
\hline 15 & 15 & 14 & 14 & 290 & 202 & 158 & 140 \\
\hline 20 & 19 & 19 & 19 & 300 & 207 & 161 & 143 \\
\hline 25 & 24 & 23 & 23 & 320 & 216 & 167 & 147 \\
\hline 30 & 29 & 28 & 28 & 340 & 225 & 172 & 151 \\
\hline 35 & 33 & 32 & 32 & 360 & 234 & 177 & 155 \\
\hline 40 & 38 & 36 & 36 & 380 & 242 & 182 & 158 \\
\hline 45 & 42 & 40 & 39 & 400 & 250 & 186 & 162 \\
\hline 50 & 47 & 44 & 42 & 420 & 257 & 191 & 165 \\
\hline 55 & 51 & 48 & 46 & 440 & 265 & 195 & 168 \\
\hline 60 & 55 & 51 & 49 & 460 & 272 & 198 & 171 \\
\hline 65 & 59 & 55 & 53 & 480 & 279 & 202 & 173 \\
\hline 70 & 63 & 58 & 56 & 500 & 285 & 205 & 176 \\
\hline 75 & 67 & 62 & 59 & 550 & 301 & 213 & 182 \\
\hline 80 & 71 & 65 & 62 & 600 & 315 & 221 & 187 \\
\hline 85 & 75 & 68 & 65 & 650 & 329 & 227 & 191 \\
\hline 90 & 79 & 72 & 68 & 700 & 341 & 233 & 195 \\
\hline 95 & 83 & 75 & 71 & 750 & 352 & 238 & 199 \\
\hline 100 & 87 & 78 & 73 & 800 & 363 & 243 & 202 \\
\hline 110 & 94 & 84 & 78 & 850 & 373 & 247 & 205 \\
\hline 120 & 102 & 89 & 83 & 900 & 382 & 251 & 208 \\
\hline 130 & 109 & 95 & 88 & 950 & 391 & 255 & 211 \\
\hline 140 & 116 & 100 & 92 & 1000 & 399 & 258 & 213 \\
\hline 150 & 122 & 105 & 97 & 1100 & 414 & 265 & 217 \\
\hline 160 & 129 & 110 & 101 & 1200 & 427 & 270 & 221 \\
\hline 170 & 135 & 114 & 105 & 1300 & 440 & 275 & 224 \\
\hline 180 & 142 & 119 & 108 & 1400 & 450 & 279 & 227 \\
\hline 190 & 148 & 123 & 112 & 1500 & 460 & 283 & 229 \\
\hline 200 & 154 & 127 & 115 & 1600 & 469 & 286 & 232 \\
\hline 210 & 160 & 131 & 118 & 1700 & 477 & 289 & 234 \\
\hline 220 & 165 & 135 & 122 & 1800 & 485 & 292 & 235 \\
\hline 230 & 171 & 139 & 125 & 1900 & 492 & 294 & 237 \\
\hline 240 & 176 & 142 & 127 & 2000 & 498 & 297 & 238 \\
\hline 250 & 182 & 146 & 130 & 2200 & 510 & 301 & 241 \\
\hline 260 & 187 & 149 & 133 & 2400 & 520 & 304 & 243 \\
\hline 270 & 192 & 152 & 135 & 2600 & 529 & 307 & 245 \\
\hline
\end{tabular}

(Sugiyono, 2009) 


\section{Harry King}

Dalam nomogram yang dibuat oleh Harry King (Sugiyono, 2009), jumlah sampel dapat ditetapkan dengan cara menarik garis lurus dari titik pada garis yang menunjukkan ukuran populasi di sebelah kanan dengan melewati titik-taraf kesalahan yang terdapat pada garis yang berada di tengah. Pada penelitian sosial, taraf kesalahan yang sering digunakan adalah 1\% dan 5\%. Gambar 7.13 menunjukkan contoh jika seandainya terdapat 200 populasi dan pada taraf kesalahan 5\% maka dengan cara menarik garis lurus, dari angka 200 pada garis_populasi, dengan melewati angka 5 pada garis taraf kesalahan akan dapat di- peroleh ukuran sampel sekitar 58\% atau 0,58 X $200=116$. Sedangkan jika jumlah populasi sebanyak 800, pada taraf signifikansi yang sama diperlukan sampel sekitar $27 \% \times 800=216$. Persentase jumlah sampel sebesar 58\% diambil dari arah anak panah yang berada di antara angka 50 dan 60 , karena titik anak panah lebih dekat dengan angka 60 maka dapat diperkirakan titik tersebut berada di sekitar angka 58, sedangkan $27 \%$ diambil dari angka yang berada di antara titik ke 20 dan 30. Selanjutnya, proporsi sampel yang telah ditemukan di atas di kalikan dengan multiple factor. Pada contoh di atas, tingkat kesalahan sam- pling yang telah dipilih adalah 5\%, oleh sebab itu diperoleh interval kepercayaan 95\% yang berasal dari $100-5$. Hal ini berarti $95 \%$ penelitian telah menggunakan prosedur penentuan sampling yang benar. Multiple factor pada interval kepercayaan (confidence interval) $95 \%$ adalah 1,195. Ukuran sampel yang telah menjadi contoh di atas, masing-masing masih perlu dikalikan dengan 1,195. Untuk jumlah populasi 200 maka jumlah sampel yang harus diambil adalah $116 \times 1,195=$ 138,6 dibulatkan menjadi 139 dan untuk jumlah populasi 800, jumlah sampel yang harus diambil adalah 216 x 1,195 = 258 . 


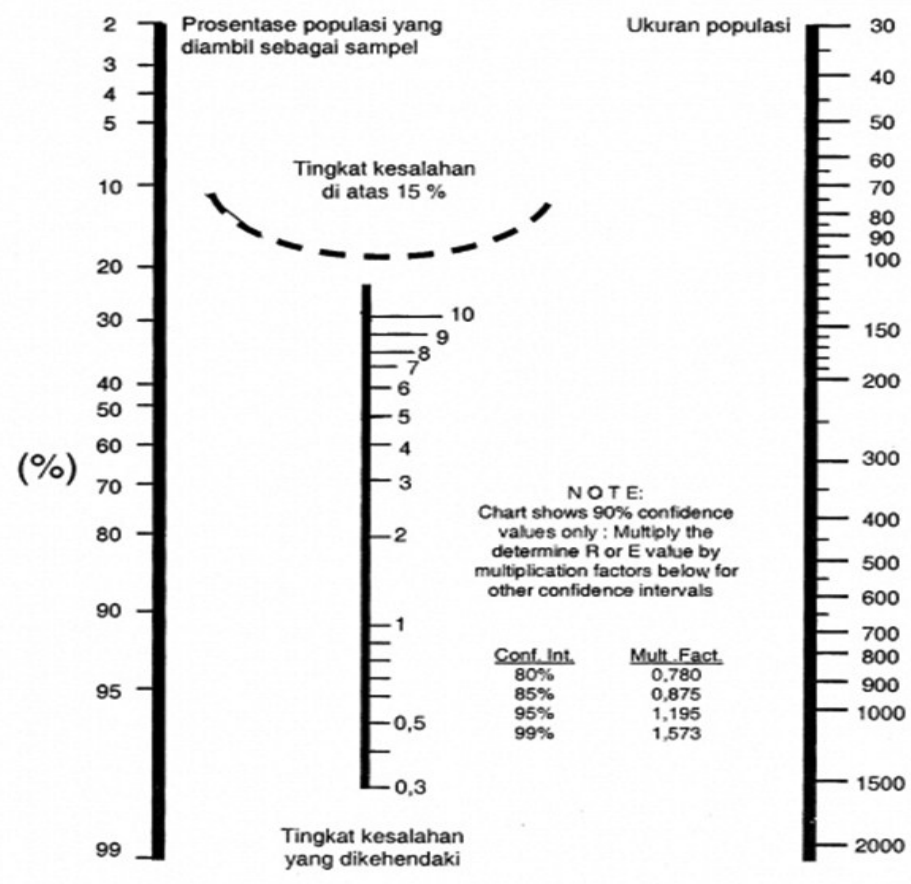

Gambar 7.13. Nomogram Harry King (Sugiyono, 2009)

\section{Edward L. Vockell}

Jumlah populasi sasaran pada wilayah yang luas sulit ditemukan. Bila hal ini terjadi, penentuan ukuran sampel dapat menggunakan batas interval kepercayaan (confidence interval). Vockell (Mulyatiningsih, 2011) memperkirakan interval kepercayaan berbasis pada ukuran sampel yang dapat disimak pada Tabel 7.2. Dalam tabel tersebut terkandung makna, jika ukuran sampel ditetapkan pada interval kepercayaan $\pm 4,9 \%$, maka peneliti mengharapkan hanya $\pm 4,9 \%$ kesalahan kesimpulan hasil penelitian yang diakibatkan oleh kesalahan pengambilan sampel. 
Tabel 7.2. Perkiraan Taraf Kepercayaan berdasarkan Ukuran Sampel menurut Vockell

\begin{tabular}{|c|c|c|c|}
\hline $\begin{array}{l}\text { Ukuran } \\
\text { Sampel }\end{array}$ & $\begin{array}{c}\text { Taraf } \\
\text { kepercayaan }\end{array}$ & $\begin{array}{l}\text { Ukuran } \\
\text { Sampel }\end{array}$ & $\begin{array}{c}\text { Taraf } \\
\text { kepercayaan }\end{array}$ \\
\hline 5 & \pm 44 & 175 & $\pm 7,4$ \\
\hline 10 & \pm 31 & 200 & $\pm 6,9$ \\
\hline 20 & \pm 22 & 225 & $\pm 6,5$ \\
\hline 30 & \pm 18 & 250 & $\pm 6,2$ \\
\hline 40 & \pm 16 & 275 & $\pm 5,9$ \\
\hline 50 & \pm 14 & 300 & $\pm 5,6$ \\
\hline 60 & \pm 13 & 400 & $\pm 4,9$ \\
\hline 70 & \pm 12 & 500 & $\pm 4,4$ \\
\hline 80 & \pm 11 & 750 & $\pm 3,6$ \\
\hline 90 & \pm 10 & 1000 & $\pm 3,1$ \\
\hline 100 & $\pm 9,8$ & 2000 & $\pm 2,2$ \\
\hline 125 & $\pm 8,8$ & 5000 & $\pm 1,4$ \\
\hline 150 & $\pm 8,0$ & & \\
\hline
\end{tabular}

\section{Jacob Cohen}

Jacob Cohen (Mulyatiningsih, 2011) menetapkan ukuran sampel berdasarkan teknik analisis datanya. Penelitian yang menggunakan analisis statistik inferensial (mengambil kesimpulan berdasarkan hasil analisis data pada sampel tetapi berlaku untuk seluruh populasi). Jika hipotesis (kesimpulan sementara) penelitian ingin diterima secara signifikan (berarti) maka peneliti sebaiknya menetapkan power yang tinggi. Keberartian kesimpulan hasil penelitian sosial sangat dipengaruhi oleh jumlah sampelnya. Ada empat faktor yang perlu dilihat dalam penentuan uku- ran sampel agar dapat memenuhi statistic power analysis yaitu sample size, significancy, directionality and effect size. Penjelasan lebih lanjut terhadap faktor-faktor yang perlu dikendalikan dalam statistic power analysis adalah sebagai berikut:

a. Ukuran sampel (sample size), power akan meningkat secara otomatis dengan meningkatnya ukuran sampel

b. Tingkat signifikansi, yaitu nilai p pada hipotesis nol yang akan ditolak. Pada penelitian sosial, signifikansi (p) pada umumnya ditetapkan pada tingkat kesalahan 0,05 dan 0,01. 
c. Directionality yaitu arah khusus hipotesis penelitian yang dirancang: pada umumnya, arah hipotesis penelitian ditetapkan pada satu arah/one tail: $a_{1}$ (positif atau negatif), atau dua arah/two tail: $a_{2}$ (positif dan negatif)

d. Effect size yaitu estimasi pengaruh ukuran sampel dari populasinya. Semakin besar jumlah sampel akan semakin kecil efeknya. Ada tiga kriteria penentuan effect size yaitu kecil/small, sedang/medium, dan besar/large. Setiap jenis analisis memiliki effect size yang berbeda. Ketentuan effect size menurut teknik analisis data dapat dirangkum pada tabel berikut.

Tabel 7.3. Effect Size Menurut Teknik Analisis Data

\begin{tabular}{|l|l|l|l|}
\hline \multirow{2}{*}{ Teknik Analisis } & \multicolumn{3}{|c|}{ Effect Size } \\
\cline { 2 - 4 } & \multicolumn{1}{|c|}{ Small } & \multicolumn{1}{c|}{ Medium } & \multicolumn{1}{c|}{ Large } \\
\hline t-test & $\mathrm{d}=, 20$ & $\mathrm{~d}=, 50$ & $\mathrm{~d}=, 80$ \\
\hline Product moment & $\mathrm{r}=, 10$ atau & $\mathrm{r}=, 30$ atau & $\mathrm{r}=, 50$ atau \\
& $\mathrm{r}^{2}=, 01$ & $\mathrm{r}^{2}=, 09$ & $\mathrm{r}^{2}=, 25$ \\
\hline Anova & $\mathrm{f}=, 10$ & $\mathrm{f}=, 25$ & $\mathrm{f}=, 40$ \\
\hline & & & \\
\hline
\end{tabular}

Untuk menetapkan ukuran sampel berdasarkan statistic power analysis, peneliti tinggal membaca ukuran sampel yang telah tertera di tabel. Estimasi ukuran sampel pada contoh di bawah ini tidak mencantumkan effect size: large dengan asumsi bahwa semua peneliti tidak mengharapkan mendapat kesalahan dalam mengambil kesimpulan hasil penelitian yang besar karena ukuran sampelnya kurang memenuhi syarat analisis.

Di bawah ini diberikan beberapa contoh penetapan ukuran sampel menggunakan statistic power analysis.

Tabel 7.4. Estimasi Ukuran Sampel untuk Analisis t-test

\begin{tabular}{|l|l|l|l|l|l|l|l|l|l|}
\hline \multicolumn{1}{|c|}{$\begin{array}{c}\text { Arah } \\
\text { hipotesis }\end{array}$} & \multicolumn{3}{|c|}{, 70} & \multicolumn{3}{c|}{, 80} & \multicolumn{3}{c|}{, 90} \\
\cline { 2 - 11 } & \multicolumn{3}{|c|}{ ES = d $=\mathrm{d}$} & \multicolumn{3}{c|}{ ES =d } \\
\cline { 2 - 11 } & .20 & .40 &, 50 & .20 & .40 &, 50 & .20 & .40 &, 50 \\
\hline $\mathrm{a}_{1}=, 01$ & 408 & 103 & 66 & 505 & 127 & 82 & 652 & 290 & 105 \\
\hline $\mathrm{a}_{1}=, 05$ & 236 & 60 & 38 & 310 & 78 & 50 & 429 & 108 & 69 \\
\hline $\mathrm{a}_{2}=, 01$ & 482 & 122 & 79 & 586 & 148 & 95 & 746 & 188 & 120 \\
\hline $\mathrm{a}_{2}=0,5$ & 316 & 78 & 50 & 393 & 99 & 64 & 526 & 132 & 85 \\
\hline
\end{tabular}


Contoh pengambilan sampel untuk t-test:

Sebuah penelitian kuasi eksperimen pada dua kelompok sampel ingin menguji hipotesis alternatif (Ha) dua arah: $\mu_{1} \neq \mu_{2}$ pada taraf signifikansi $\mathrm{a}_{2}=0,05$, dengan effect size sedang, $(\mathrm{d})=0.50$ dan power sebesar 0,80 maka diperlukan jumlah sampel 64 untuk masing-masing kelompok. Sebaliknya, apabila peneliti hanya memiliki sampel 50 orang pada masing-masing kelompok, maka hasil penelitian hanya memiliki power 0,70 atau power tetap 0,80 tetapi hipotesis hanya satu arah $\left(\mathrm{a}_{1}\right)$ pada taraf kepercayaan 0,05 .

Contoh ukuran sampel untuk analisis Product Moment ada pada tabel 7.5. Contoh kasus: apabila peneliti ingin menguji hipotesis alternatif dua arah $\left(\mathrm{a}_{2}\right)$ hubungan antara lama menjadi guru dengan skor penilaian kinerja mengajar pada power 0,90 dan effect size sedang $r=$ 0,30 dan taraf signifikansi $\mathrm{a}_{2}=0,01$ maka diperlukan sampel sebanyak 158 orang. Jika peneliti hanya memiliki sampel sebesar 67 orang, peneliti memperoleh dukungan pada effect size yang sama $(0,30)$ tetapi power menurun menjadi 0,70 dan taraf signifikansi $\mathrm{a}_{2}=0,05$.

Tabel 7.5. Estimasi Ukuran Sampel untuk Analisis Produk-Moment

\begin{tabular}{|c|c|c|c|c|c|c|c|c|c|}
\hline \multicolumn{10}{|c|}{ Power } \\
\hline \multirow{3}{*}{$\begin{array}{c}\text { Arah } \\
\text { hipotesis }\end{array}$} & \multicolumn{3}{|c|}{,70 } & \multicolumn{3}{|c|}{,80 } & \multicolumn{3}{|c|}{,90 } \\
\hline & \multicolumn{3}{|c|}{$\begin{array}{c}E S= \\
r\end{array}$} & \multicolumn{3}{|c|}{$\begin{array}{c}E S= \\
r\end{array}$} & \multicolumn{3}{|c|}{$\begin{array}{c}E S= \\
r\end{array}$} \\
\hline & .20 & .30 & ,40 & .20 & .30 & ,40 & .20 & .30 & ,40 \\
\hline$a_{1}=, 01$ & 201 & 88 & 48 & 247 & 108 & 59 & 320 & 139 & 76 \\
\hline $\mathrm{a}_{1}=, 05$ & 117 & 52 & 28 & 153 & 68 & 37 & 211 & 92 & 50 \\
\hline$a_{2}=, 01$ & 237 & 103 & 56 & 287 & 125 & 68 & 365 & 158 & 86 \\
\hline$a_{2}=0,5$ & 153 & 67 & 37 & 194 & 85 & 46 & 259 & 113 & 62 \\
\hline
\end{tabular}

Contoh ukuran sampel untuk analisis Analisis of Varians ada pada tabel 7.6. Contoh kasus: Jika peneliti ingin menguji hipotesis alternatif (Ha) perbedaan gaya hidup antara PNS yang bekerja sebagai dosen, guru, dan karyawan pada taraf signifikansi 0,05, effect size yang dipilih kecil $(\mathrm{f}=0,25)$ dan power 0,80 maka jumlah sampel yang harus diambil adalah 52 orang untuk masing-masing kelompok (dosen, guru, dan karyawan), sampel keseluruhan adalah 52 × $3=156$ orang. Tabel 1.8 Estimasi Ukuran Sampel untuk Analisis of Varians 


\begin{tabular}{|c|c|c|c|c|c|c|c|c|c|c|}
\hline \multicolumn{11}{|c|}{ Power } \\
\hline \multirow{3}{*}{$\begin{array}{l}\text { Arah } \\
\text { hipotes } \\
\text { is }\end{array}$} & \multirow{3}{*}{$\begin{array}{c}\mathrm{n} \\
\text { keompok }\end{array}$} & \multicolumn{3}{|c|}{,70 } & \multicolumn{3}{|c|}{,80 } & \multicolumn{3}{|c|}{,90 } \\
\hline & & \multicolumn{3}{|c|}{$\begin{array}{c}E S= \\
f\end{array}$} & \multicolumn{3}{|c|}{$\begin{array}{c}E S= \\
f\end{array}$} & \multicolumn{3}{|c|}{$\begin{array}{c}E S= \\
f\end{array}$} \\
\hline & & .10 & .20 & ,25 & .10 & .20 & 25 & .10 & .20 & ,25 \\
\hline \multirow[t]{4}{*}{$a=, 01$} & 3 & 387 & 98 & 63 & 464 & $\begin{array}{c}11 \\
7\end{array}$ & 76 & $\begin{array}{c}58 \\
2\end{array}$ & 147 & 95 \\
\hline & 4 & 326 & 83 & 53 & 388 & 98 & 63 & $\begin{array}{c}48 \\
3\end{array}$ & 122 & 78 \\
\hline & 5 & 283 & 72 & 46 & 336 & 80 & 55 & $\begin{array}{c}41 \\
6\end{array}$ & 105 & 68 \\
\hline & 6 & $\begin{array}{c}25 \\
3\end{array}$ & 64 & 41 & 299 & 76 & 49 & 368 & $\begin{array}{l}9 \\
3\end{array}$ & 60 \\
\hline \multirow{4}{*}{$a=, 05$} & 3 & $\begin{array}{c}25 \\
8\end{array}$ & 65 & 42 & 322 & 81 & 52 & 421 & $\begin{array}{c}10 \\
4\end{array}$ & 68 \\
\hline & 4 & $\begin{array}{c}22 \\
1\end{array}$ & 56 & 36 & 274 & 69 & 45 & 354 & $\begin{array}{l}8 \\
9\end{array}$ & 58 \\
\hline & 5 & $\begin{array}{c}19 \\
5\end{array}$ & 49 & 32 & 249 & 61 & 39 & 309 & $\begin{array}{l}7 \\
8\end{array}$ & 50 \\
\hline & 6 & $\begin{array}{c}17 \\
5\end{array}$ & 44 & 29 & 215 & 54 & 35 & 275 & $\begin{array}{l}6 \\
9\end{array}$ & 45 \\
\hline
\end{tabular}

Penentuan ukuran sampel untuk mencapai analisis regresi sedikit berbeda dengan cara sebelumnya. Penentuan ukuran sampel dapat menggunakan cara lain yang lebih mudah. Ukuran sampel analisis multivariate seperti, regresi ganda, korelasi parsial dan SEM (Structural Equation Modeling), dapat ditetapkan sekitar 5-10 x jumlah variabel yang diobservasi (Arief Wibowo, 2004). Jika terdapat 13 variabel yang diobservasi maka ukuran sampel minimal sekitar 65 s/d 130 orang yang berasal dari $5 \times 13=65$ atau $13 \times 10=130$.

\section{Borg dan Gall}

Peneliti sering mengalami keterbatasan waktu, tenaga dan biaya untuk mengambil sampel dengan jumlah yang besar. Dalam keadaan seperti ini, peneliti dapat mencari dukungan referensi apabila ingin mengambil sampel dalam jumlah yang relatif sedikit tetapi memenuhi syarat pengambilan kesimpulan. Borg and Gall (Mulyatiningsih, 2011) menyatakan bahwa sampel minimal untuk penelitian korelasional adalah 30 kasus, sampel 
minimal penelitian causal-comparative dan eksperimen adalah 15-20 kasus untuk tiap-tiap kelompok yang akan dibandingkan. Penelitian survei, sampel minimal adalah 100 orang untuk tiap-tiap sub kelompok mayor dan 20-50 orang untuk setiap sub kelompok minor.

\section{LEMBAR KERJA}

Merumuskan Masalah

Petunjuk:

Mahasiswa mempelajari kembali teknik sampling, baik secara random maupun nonrandom sampling. Selanjutnya selesaikan soal-soal berikut.

Misalkan penduduk suatu wilayah dikelompkan sebagai berikut:

\begin{tabular}{|c|c|}
\hline Tingkat Pendidikan & Komposisi Populasi \\
\hline SD ke bawah & 6.000 \\
\hline SLTP & 2.500 \\
\hline SLTA & 1.000 \\
\hline PT & 500 \\
\hline Jumlah & 10.000 \\
\hline
\end{tabular}

Tugas:

1. Berapa jumlah sampel sebaiknya diambil peneliti menurut sampel acak proposional berdasarkan tingkat penduduk.

2. Berapa jumlah sampel menurut tingkat pendidikan jika diambil secara tidak proporsional

\section{RANGKUMAN}

Populasi adalah seluruh data yang menjadi perhatian kita dalam suatu ruang lingkup dan waktu yang kita tentukan. Jadi populasi berhubungan dengan data, bukan manusianya. Kalau setiap manusia memberikan suatu data maka, maka banyaknya atau ukuran populasi akan sama dengan banyaknya manusia Sampel adalah sebagai bagian dari populasi, sebagai contoh (monster) yang diambil dengan menggunakan cara-cara tertentu.Teknik sampling adalah cara untuk menentukan sampel yang jumlahnya sesuai dengan ukuran sampel yang akan dijadikan sumber data sebenarnya, dengan memperhatikan sifat-sifat dan penyebaran populasi agar diperoleh sampel yang representatif. Teknik sampling pada dasarnya dapat dikelompokkan menjadi dua yaitu probability sampling dan nonprobability sampling. Probability sampling adalah teknik sampling yang memberikan peluang yang sama bagi setiap unsur (anggota) populasi untuk dipilih menjadi anggota sampel. Teknik sampel ini meliputi: simple random sampling, proportionate 
stratified random sampling, disproportionate stratified random sampling, dan area (cluster) sampling (sampling menurut daerah). Nonprobability sampling adalah teknik yang tidak memberi peluang/kesempatan yang sama bagi setiap unsur atau anggota populasi untuk dipilih menjadi sampel. Teknik sampel ini meliputi: sampling sistematis, sampling kuota, sampling aksidental, purposive sampling, sampling jenuh, dan snowball sampling.

Untuk menentukan jumlah sampel minimal yang harus diambil, ada beberapa cara yang diambil dari berbagai referensi, misalnya: Isaac dan Michael, Harry King, Edward L. Vockell, Jacob Cohen, Borg dan Gall.

\section{TUGAS}

1. Setelah Anda mempelajari bab ini, Anda ditugaskan kembali ke sekolah tempat Anda menemukan masalah untuk mendata populasi dan sampel penelitian.

2. Jelaskan bagaimana cara Anda mengambil sampel penelitian tersebut!.

3. Dengan meningkatnya jumlah sampel yang representatif sesuai dengan karakteristik populasi, apakah akan meningkatkan akurasinya (ketetapatan pengambilan sampel)? Buatlah dalam bentuk makalah dengan bagian pokok yang harus ada adalah Pendahuluan, Isi, dan Kesimpulan. 


\section{BAB 8 TEKNIK PENGUMPULAN DATA DANPENGUKURAN}

$\mathrm{P}$ engumpulan data adalah suatu proses pengadaan data primer untuk keperluan penelitian. Pengumpulan data dan pengukuran merupakan langkah yang amat penting dalam metode ilmiah, karena pada umumnya data yang dikumpulkan digunakan untuk menguji hipotesis yang dirumuskan. Data dikumpulkan dengan instrumen yang telah di desain sebelumnya dengan cara-cara tertentu. Ada beberapa cara atau teknik yang dapat digunakan untuk mengumpulkan data kuantitatif dan kualitatif, masingmasing teknik tersebut memiliki karakteristik yang berbeda dari yang lain serta mempunyai kelebihan dan kekurangan. Oleh sebab itu, peneliti harus mempertimbangkan hal tersebut dalam memlilih teknik agar sesuai dengan tujuan dan desain penelitian. Pada bab ini akan dibicarakan tentang macammacam teknik pengumpulan data berupa nontes, skala pengukuran, teknik pengukuran data berupa tes, validitas dan reliabilitas instrumen. Kemampuan akhir yang diharapkan setelah mahasiswa mempelajari bab ini yaitu:

1. Merancang dan menyusun instrumen tes sebagai bahan dalam penyusunan proposal penelitian

2. Merancang dan menyusun instrumen angket sebagai bahan dalam penyusunan proposal penelitian

3. Merancang dan menyusun pedoman wawancara terstandar sebagai bahan dalam penyusunan proposal penelitian

4. Melakukan pengukuran menggunakan skala dan instrumen penelitian

\section{A. TEKNIK PENGUMPULAN DATA}

Ada beberapa teknik pengumpulan data yaitu, wawancara, angket, observasi, dan studi dokumenter.

\section{Wawancara}

Wawancara atau interview adalah suatu bentuk komunikasi verbal antara peneliti dengan responden untuk memperoleh informasi tertentu. Peneliti menerima informasi tanpa membantah, mengecam, menyetujui, atau tidak menyetujui. Peneliti berfungsi sebagai instrumen untuk menggali informasi dari responden. Wawancara merupakan alat yang ampuh untuk mengungkapkan kenyataan hidup, apa yang dipikirkan atau dirasakan orang tentang aspek kehidupan. Melalui tanya jawab peneliti dapat memasuki alam pikiran orang lain, sehingga ia memperoleh gambaran tentang dunia mereka. Jadi wawancara berfungsi deskriptif yaitu melukiskan dunia kenyataan seperti dialami orang lain, dari bahan-bahain itu peneliti memperoleh gambaran yang 
lebih obyektif tentang masalah yang diselidikinya. Selain berfungsi deskriptif, wawancara dapat pula berfungsi eksploratif, yakni bila masalah yang dihadapi oleh peneliti masih samar-samar, karena belum pernah diselidiki secara mendalam oleh orang lain.

Dalam wawancara terstandar, pewawancara menggunakan pedoman wawancara berisi pertanyaan yang telah dirumuskan dengan cermat kepada subyek untuk mendapatkan respon secara langsung. Pertanyaan-pertanyaan harus diberikan dengan urutan, prosedur, dan teknik yg sama untuk masingmasing subyek. Meskipun demikian, peneliti harus mengantisipasi kemungkinan terjadinya hal yg tidak biasa dan cara penanganannya.

Bentuk (format) pertanyaan yang disusun dalam pedoman wawancara bervariasi tergantung pada arah serta keterbatasan yang ditekankan pada situasi wawancara. Secara garis besar bentuk pertanyaan wawancara dapat dibedakan menjadi:

1) Terstruktur, jika jawaban atas pertanyaan itu telah ditentukan terlebih dahulu secara pilihan berganda.

Misalnya: Bila menghadapi kesulitan belajar di rumah, kepada siapa Anda minta bantuan? Bapak, ibu, kakak?

2) Tidak terstruktur, jika jawaban atas pertanyaan sesuai dgn kehendak responden dan dalam bahasanya sendiri.

Misalnya: Menurut Anda, apa keuntungan dan kerugian adanya penetapakan sekolah tertentu sebagai sekolah unggulan di daerahdaerah?

3) Semi terstruktur, jika pertanyaan diajukan berbentuk terstruktur, lalu berdasarkan respon yg diberikan responden, diajukan pertanyaan terbuka untuk menggali informasi yg lebih mendalam. Peneliti dapat mengajukan pertanyaan berikut:

- Apakah Anda setuju bila Pendidikan Agama dimasukkan dalam kurikulum muatan lokal? Berdasarkan respon terhadap pertanyaan ini, peneliti atau pewawancara mengajukan pertanyaan lebih lanjut untuk, menggali alasannya, misalnya:

- Apa yang menjadi dasar pertimbangan atas ketidaksetujuan /persetujuan Anda tersebut? 
Wawancara adalah komunikasi social antara dua pihak yaitu peneliti dan responden. Agar wawancara dapat dilakukan, kedua pihak harus dapat bertemu dalam suasana kesediaan berkomunikasi. Peneliti harus memperhatikan hal-hal yang memudahkan komunikasi, seperti:

1) Menciptakan suasana akrab, tidak ada rasa curiga, takut, enggan, atau malu.

2) Memulai dengan ucapan selamat, perkenalkan diri, tunjukkan kartu pengenal, jelaskan tujuan penelitian, dan pentingnya keterangan dari responden bagi penelitian itu.

3) Ungkapkan bahwa intervieu itu bukan ujian atau tes, tidak ada jawaban yang benar/salah, bahwa semua pertanyaan itu mudah dijawab karena berkaitan dengan pengalaman, kehidupan, pikiran, dan perasaannya.

4) Peneliti harus menunjukkan rasa percaya diri, tapi jangan berlebihan karena dapat menimbulkan antipati/antagonis.

5) Suasana akrab jangan membuat peneliti menjadi pendengar saja, jangan membiarkan diri dibawa arus percakapan responden.

6) Lakukan 'probing'/korek keterangan yang lebih jelas jika jawaban responden kurang jelas atau kurang lengkap, atau jika ia tidak sanggup menjawab, mungkin karena tidak tau atau kurang mengerti.

7) Jangan sampai menuduh/ mempersalahkan responden atas keterangan yang tidak benar.

Salah satu tugas penting yang harus dilakukan peneliti dalam teknik wawancara ialah mencatat hasil wawancara. Dalam pelaksanaannya peneliti dapat membuat catatan langsung, namun ini membutuhkan kemampuan menulis cepat agar butir-butir penting dari respon subyek tidak tertinggal atau tercatat sehingga data yang diperoleh memiliki akurasi yang tinggi. Mencatat hasil wawancara terbuka yang tak terstruktur jauh lebih sulit dari wawancara teratruktur. Tak mungkin pewawancara mengingat segala sesuatu yang diucapkan selama wawancara itu. Hanya sebagain kecil dapat diingatnya walaupun ia mencatatnya segera setelah wawancara selesai. Untuk mengatasi kelemahan di atas, pewawancara dapat menggunakan alat bantu rekaman, seperti tape recorder. Dengan alat ini pewawancara dapat memusatkan perhatiannya pada proses wawancara tanpa harus terganggu untuk mengingat atau mencatat respon yang diberikan oleh subyek.

Tugas peneliti selanjutnya adalah mengakhiri wawancara. Mengakhiri wawancara dalam interview yang singkat dapat dilakukan dengan 
mengucapkan terima kasih disertai senyum. Akan tetapi, wawancara yang bersifat kualitatif, intensif, mendalam, makan waktu lama, dan tidak dapat diakhiri begitu saja. Sebelum berpisah, suatu pujian atas lukisan, benda, atau tanaman hias yang indah dapat meninggalkan kesan yang menyenangkan pada responden.

\section{Angket}

Kuesioner merupakan teknik pengumpulan data yang dilakukan dengan cara memberi seperangkat pertanyaan atau pernyataan tertulis kepada responden untuk dijawabnya (Sugiyono, 2017). Kuesioner merupakan teknik pengumpulan data yang efisien bila peneliti tahu dengan pasti variabel yang akan diukur dan tahu apa yang bisa diharapkan dari responden. Selain itu, kuesioner juga cocok digunakan bila jumlah responden cukup besar dan tersebar di wilayah yang luas. Kuesioner dapat berupa pertanyaan/pernyataan tertutup atau terbuka, dapat diberikan kepada responden secara langsung atau dikirim melalui pos, atau internet.

Bila peneliti dilakukan pada lingkup yang tidak terlalu luas, sehinggga kuesioner dapat diantarkan langsung dalam waktu singkat, maka pengiriman angket kepada responden tidak melalui pos. Dengan adanya kontak langsung antara peneliti dengan responden akan menciptakan suatu kondisi yang cukup baik, sehingga responden dengan sukarela akan memberikan data obyektif dan cepat.

Uma Sekaran (Sugiyono, 2017) mengemukakan beberapa prinsip dalam penulisan angket sebagai titik pengumpulan data sebagai berikut.

1) Prinsip penulisan angket

Prinsip ini menyangkut beberapa faktor yaitu: isi dan tujuan pertanyaan, bahasa yang digunakan mudah, pertanyaan tertutup terbuka-negatif positif, pertanyaan tidak mendua, tidak menanyakan hal-hal yang sudah lupa, pertanyaan tidak mengarahkan, panjang pertanyaan, dan urutan pertanyaan.

a) Isi dan tujuan pertanyaan

Yang dimaksud disini adalah, apakah isi pertanyaan tersebut merupakan bentuk pengukuran atau bukan? Kalau berbentuk pengukuran, maka dalam membuat pertanyaan harus teliti, setiap pertanyaan harus disusun dalam skala pengukuran dan jumlah itemnya mencukupi untuk mengukur variabel yang diteliti. 
b) Bahasa yang digunakan

Bahasa yang digunakan dalam penulisan kuesioner (angket) harus disesuaikan dengan kemapuan berbahasa responden. Jika responden tidak dapat berbahasa Indonesia, maka angket jangan disusun dalam bahasa Indonesia. Jadi bahasa yang digunakan dalam angket harus memperhatikan jenjang pendidikan responden, keadaan sosial budaya, dan frame of reference dari responden.

c) Tipe dan bentuk pertanyaan

Tipe pertanyaan dalam angket dapat terbuka atau tertutup dan bentuknya dapat menggunakan kalimat positif atau negatif.

Pertanyaan terbuka adalah pertanyaan yang mengharapkan responden untuk menuliskan jawabannya berbentuk uraian tentang suatu hal. Contoh: bagaimanakah tanggapan Anda terhadap iklan di TV saat ini? Sebaliknya pertanyaan tertutup, adalah pertanyaan yang mengharapkan jawaban singkat atau mengharapkan responden untuk memilih salah satu alternatif jawaban dari setiap pertanyaan yang telah tersedia. Setiap pertanyaan angket yang mengharapkan jawaban berbentuk data nominal, ordinal, inteval, dan ratio, adalah bentuk pertanyaan tertutup.

Pertanyaan tertutup akan membantu responden untuk menjawab dengan cepat dan juga memudahkan peneliti dalam melakukan analisis data terhadap seluruh angket yang telah terkumpul. Pertanyaan-pertanyaan dalam bentuk angket perlu dibuat kalimat positif dan negatif agar responden dalam memberikan jawaban setiap pertanyaan lebih serius, dan tidak mekanistis.

d) Pertanyaan tidak mendua

Setiap pertanyaan dalam angket jangan mendua (double barreled) sehingga menyulitkan responden untuk memberikan jawaban.

Contoh: bagaimana pendapat Anda tentang kualitas dan relevansi pendidikan saat ini? Ini adalah pertanyaan yang mendua, karena menanyakan tentang dua hal sekaligus, yaitu kualitas dan relevansi. Sebaiknya pertanyaan tersebut dijadikan menjadi dua. 
- Bagaimanakah kualitas pendidikan?

- Bagaimanakah relevansi pendidikan?

e) Tidak menanyakan yang sudah lupa

Setiap pertanyaan dalam instrumen angket, sebaiknya juga tidak menanyakan hal-hal sekiranya responden sudah lupa, atau pertanyaan yang memerlukan jawaban dengan berpikir berat.

Contoh: bagaimana kualitas pendidikan sekarang bila dibandingkan dengan 30 tahun lalu? Menurut Anda, bagaimana cara mengatasi krisis ekonomi saat ini? (kecuali penelitian yang mengharapkan pendapat para ahli). Kalau misalnya umur responden yang diberi angket baru 25 tahun, dan pendidikannnya rendah, maka akan sulit memberikan jawaban.

f) Pertanyaan tidak menggiring

Pertanyaan dalam angket sebaiknya juga tidak menggiring ke jawaban yang baik saja atau ke yang jelek saja. Misalnya: bagaimanakah prestasi belajar Anda selama di sekolah dulu? Jawaban responden tentu cenderung akan menyatakan baik. Bagaimanakah prestasi kerja Anda selama setahun terakhir? Jawabannya cenderung akan baik.

g) Panjang pertanyaan

Pertanyaan dalam angket sebaiknya tidak terlalu panjang sehingga akan membuat jenuh responden dalam mengisi. Bila jumlah variabel banyakm sehingga memerlukan instrumen yang banyak, maka instrumen tersebut dibuat bervariasi dalam penampilan, model skala pengukuran yang digunakan, dan cara mengisinya. Disarankan empirik jumlah pertanyaan yang memadai adalah antara $20 \mathrm{~s} / \mathrm{d} 30$ pertanyaan.

h) Urutan pertanyaan

Urutan pertanyaan dalam angket, dimulai dari yang umum menuju ke hal yang spesifik, atau dari hal yang mudah menuju ke hal yang sulit, atau diacak. Hal ini perlu dipertimbangkan karena secara psikologis akan mempengaruhi semangat responden untuk menjawab. Kalau pada awalnya sudah diberi pertanyaan yang sulit, atau yang spesifik, maka responden akan patah semangat untuk mengisi angket yang telah mereka terima. Urutan pertanyaan yang diacak perlu dibuat tingkat kematangan responden terhadap masalah yang ditanyakan sudah tinggi. 


\section{2) Prinsip pengukuran angket}

Angket yang diberikan kepada responden adalah merupakan instrumen peneliti, yang digunakan untuk mengukur variabel yang akan diteliti. Oleh karena instrumen angket tersebut harus dapat digunakan untuk mendapatkan data yang valid dan reliabel tentang variabel yang diukur. Supaya diperoleh data penelitian yang valid dan reliabel, maka sebelum instrumen angket tersebut diberikan pada responden, maka perlu diuji validitas dan reliabilitasnya terlebih dahulu. Instrumen yang tidak valid dan reliabel bila digunakan untuk mengumpulkan data, akan menghasilkan data yang tidak valid dan reliabel pula.

3) Prinsip fisik angket

Penampilan fisi angket sebagai alat pengumpul data akan mempengaruhi respon atau keseriusan responden dalam mengisi angket. Angket yang dibuat di kertas buram, akan mendapat respon yang kurang menarik bagi responden, bila dibandingkan angket yang dicetak dalam kertas yang bagus dan berwarna. Tetapi angket yang dicetak di kertas yang bagus dan berwarna akan menjadi mahal.

\section{Observasi}

Observasi (Sugiyono, 2017) adalah metode pengumpulan data yang menggunakan pengamatan terhadap subyek penelitian. Observasi dilakukan untuk mengamati dan mencatat secara sistematis terhadap gejala yang tampak pada objek penelitian. Dengan observasi kita memperoleh informasi tentang kelakuan manusia seperti terjadi dalam kenyataan yang sukar diperoleh dari metode lain. Selain itu, observasi juga dapat berfungsi sebagai eksplorasi, jika peneliti belum memiliki banyak keterangan tentang masalah yang diselidiki. Pelaksanaan teknik observasi dapat dilakukan dalam beberapa cara. Penentuan dan pemilihan cara tersebut tergantung pada situasi objek yang akan diamati berikut ini:

1) Observasi partisipan

Observasi partisipan adalah suatu proses pengamatan dimana peneliti merupakan bagian dari kelompok yang diteliti, misalnya: termasuk suku bangsa, anggota perkumpulan, atau pekerja dalam perusahaan yang sedang diteliti. Dalam teknik ini hal yang perlu diperhatikan adalah jangan sampai observee tau bahwa observer memperhatikannya dan upayakan pencatatan yang baik, sehingga tidak menimbulkan kecurigaan. 
2) Observasi nonpartisipan

pabila peneliti tidak berperan serta dalam kehidupan observee dan secara terpisah berkedudukan sebagai pengamat, maka teknik ini disebut sebagai observasi non partisipan. Hal yang perlu diperhatikan dalam observasi jenis ini adalah pencatatan harus dilakukan di luar pengetahuan orang-orang yang diamati, dan observer harus membina hubungan orang-orang yang diamati. Kehadiran observer dapat mempengaruhi kelakuan obervee, peneliti harus sanggup menyesuaikan diri dalam situasi itu, dan jangan menonjol, agar tidak mempengaruhi kewajaran kelakuan observee.

a. Observasi terstruktur

Observasi terstruktur adalah observasi yang telah dirancang secara sistematis, tentang apa yag akan diamati, kapan dan dimana tempatnya. Jadi observasi terstruktur dilakukan apabila peneliti telah tahu dengan pasti tentang variabel apa yang akan diamati. Dalam melakukan pengamatan peneliti menggunakan instrumen penelitian yang telah diuji validitas dan reliabilitasnya. Pedoman wawancara terstruktur, atau angket tertutup dapat juga digunakan sebagai pedoman untuk melakukan observasi.

b. Observasi tidak terstruktur

Observasi tidak terstruktur adalah observasi yang tidak dipersiapkan secara sistematis tentang apa yang akan diobservasi. Hal ini dilakukan karena peneliti tidak tahu secara pasti tentang apa yang akan diamati. Dalam melakukan pengamatan penliti tidak menggunakan instrumen yang telah baku, tetapi hanya berupa rambu-rambu pengamatan.

\section{Studi dokumenter}

Studi dokumenter (Sukmadinata, 2012) adalah merupakan suatu teknik pengumpulan data dengan menghimpun dan menganalisis dokumen-dokumen, baik dokumen tertulis, gambar mauoun elektronik.

Dokumen-dokumen yang dihimpun dipilih yang sesuai dengan tujuan dan fokus masalah. Jika fokus masalah penelitiannya berkaitan dengan kebijakan pendidikan, dan tujuannya mengkaji kebijakankebijakan pendidikan untuk pengembangan karakter bangsa, maka yang dicari adalah dokumen-dokumen, undang-undang, Kepres, PP, Kepmen, kurikulum, pedoman-pedoman sampai dengan juklak dan juknis yang berkaitan dengan kebijakan pengembangan karakter bangsa. 


\section{LEMBAR KERJA}

Petunjuk:

Mahasiswa mengkaji kembali prosedur penyusunan instrumen dan jenis-jenis instrumen menurut kegunaannya. Selanjutnya selesaikan tugas berikut.

Seorang peneliti ingin mengetahui sikap mahasiswa prodi Pendidikan Matematika STKIP Gotong Royong Masohi terhadap profesi guru.

1. Buatlah kisi-kisi instrumen tentang penelitian di atas. Yang mencakup variabel, sub variabel, indikator yang diukur.

a. Variabel yang diukur:

b. Aspek/sub variabel:

c. Indikator yang diukur:

2. Rumuskan butir-butir petanyaannya
a.
b.
c.

\section{B. MACAM-MACAM SKALA PENGUKURAN}

Skala pengukuran merupakan kesepakatan yang digunakan sebagai acuan untuk menentukan panjang pendeknya interval yang ada dalam alat ukur, shingga alat ukur tersebut bila digunakan dalam pengukuran akan menghasilkan data kuantitaif.

Teknik membuat skala menurut Nazir, serta Good dan hatt (Sukardi, 2003) adalah cara mengubah fakta-fakta kualitatif yang melekat pada objek atau subjek penelitian menjadi urutan kuantitatif. Pembuatan skala pengukuran ini dibuat dengan mendasarkan pada dua asumsi.

1. Ilmu pengetahuan pada akhir-akhir ini lebih cenderung menggunakan prinsip matematika

2. Ilmu pengetahuan semakin menuntut presisi yang lebih baik utamanya dalam hal mengukur gradasi, misalnya sangat setuju, setuju, tidak setuju, sangat tidak setuju; atau dalam urutan angka misalnya 5,4,3,2,1.

Dalam penelitian pendidikan, skala yang dibuat pada umumnya terbatas hanya cocok untuk satu populasi tertentu. Seperti halnya persyaratan instrumen dalam pembuatan skala yang baik, peneliti sebaiknya juga harus memenuhi persyaratan validitas dan reliabilitas yang tinggi.

Ada beberapa macam jenis skala yang dapat diterapkan dalam penelitian pendidikan khususnya maupun pendidikan tingkah laku pada umumnya. Beberapa skala tersebut (Sukardi, 2003) yaitu skala Likert, skala Thurstone, skala Guttman, skala Simantik, skala Rating. 


\section{Skala Likert}

Skala Likert menilai sikap atau tingkah laku yang diinginkan oleh para peneliti dengan cara mengajukan beberapa pertanyaan kepada responden. Kemudian responden diminta memberikan pilihan jawaban dalam skala ukur yang telah disediakan sangat setuju (SS), setuju (S), tidak setuju (TS), sangat tidak setuju (STS) dengan memberikan tanda silang (x) pada jawaban yang sesuai dengan pertimbangan mereka.

Untuk melakukan penyekoran skala Likert, jawaban diberi bobot atau disamakan dengan nilai kuantitatif 4,3,2,1, untuk empat pilihan pernyataan positif. Dan 1,2,3,4 untuk pernyataan yang bersifat negatif. Peneliti dalam membuat skala Likert pada tidak hanya membatasi skala ukur dengan empat tingkatan saja, seringkali mereka membuat dengan 7,8, maupun 9 pilihan. Disamping itu, peneliti juga dapat menggunakan pilihan ganjil, misalnya 5,4,3,2,1. Atau pilihan genap seperti 4,3,2,1.

Contoh item positif dan item negatif

\begin{tabular}{|l|c|c|c|c|}
\hline pernyataan & SS & S & TS & STS \\
\hline Matematika merupakan mata pelajaran favorit & & & & \\
\hline Saya tidak senang dengan mata pelajaran matematika & & & & \\
\hline
\end{tabular}

Responden yang senang dengan pelajaran matematika pasti akan memberikan pilihan 4 pada pernyataan pertama, dan pilihan 4 pada pernyataan negatif. Jika di skor jumlah bobot akan menjadi $4+4=8$. Dari sistem bobot skor memberikan arti bahwa (SS) pada pernyataan pertama dan (STS) pada pernyataan kedua menunjukan bahwa responden tersebut memiliki sikap positif terhadap objek matematika.

Seorang responden yang tidak serius akan menjawab 4 pada pernyataan pertama, dan 1 pada pernyataan kedua. Dan jika di skor maka hasil skor $4+1=5$. Dari sistem bobot skor memberikan arti bahwa (SS) pada pernyataan pertama dan sikap atau tidak konsisten terhadap objek matematika.

\section{Skala Thrustone}

Skala pengukuran jenis kedua adalah skala sikap individu yang telah dikembangkan oleh Thrustone. Dia mengembangkan metode pengukuran untuk menilai secars spesifik terhadap objek atau subjek yang hendak diteliti. Perbedaannya bila skala Likert menilai sikap dengan cara menanyakan responden untuk menunjukan tingkat atau derajat sangat setuju (SS), setuju (S), tidak setuju (TS), dan sangat tidak setuju (STS) 
melalui pernyataan atau pertanyaan mana yang paling mendekati kecocokan jawaban dengan pilihan sikap mereka, skala Thrustone menilai sikap dengan cara merepresentasikan pertanyaan atau pernyataan tentang topik yang disusun dari yang tidak favorit, netral, dan sangat tidak disenangi. Responden dalam hal ini dianjurkan untuk memilih pernyataan item yang hampir mendekati atau cocok dengan pilihan sikap mereka.

Salah satu contoh skala pengukuran yang dibuat dengan model skala ini diantaranya dapat dilihat pada contoh berikut, tentang pertanyaan mengenai kepuasan seorang siswa terhadap penilaian hasil belajar.

Bagaimana Anda puas dengan hasil belajar Anda?

\begin{tabular}{ccccccccccc}
$>$ & 2 & 3 & 4 & 5 & 6 & 7 & 8 & 9 & 10 & 11 \\
\hline A & B & C & D & E & F & G & H & I & J & K \\
\hline Sangat disenangi & & Netral & & & $\begin{array}{l}\text { Sangat } \\
\text { disenangi }\end{array}$ & tidak
\end{tabular}

Skala Thurstone tidak terlalu banyak digunakan sebagai instrumen di bidang pendidikan karena model ini mempunyai beberapa kelemahan yang diantaranya seperti berikut:
a. Memerlukan terlalu banyak pekerjaan untuk membuat skala
b. Nilai pada skala yang telah dibuat memungkinkan pada skor sama mempunyai sikap yang berbeda
c. Nilai yang dibuat dipengaruhi oleh sikap para juri atau penilai
d. Memerlukan tim penilai yang objektif.

\section{Skala Guttman}

Tujuan utama pembuatan skala model ini pada prinsipnya adalah untuk menentukan, jika sikap yang diteliti benar-benar mencakup satu dimensi. Sikap dikatakan berdimensi tunggal bila sikap tersebut menghasilkan skala kumulatif. Sebagai contoh, jika seorang responden yang setuju terhadap item 2, maka ia berarti juga setuju terhadap item nomor 1, sedangkan seorang responden yang setuju dengan item 3 juga berarti ia setuju pada item nomor 2 dan 1 dan seterusnya. Dengan kata lain, seseorang yang setuju pada item tertentu dalam tipe skala akan mempunyai skor yang lebih tinggi pada skala total daripada seseorang yang tidak setuju pada item tersebut. 
Responden, sebagai contohnya ditanyakan tentang apakah setuju atau tidak terhadap peran organisasi guru dan orang tua.

a. Asosiasi guru-orang tua murid mempunyai peran penting dalam perkembangan sekolah

b. Asosiasi guru-orang tua murid mempunyai pengaruh kuat terhadap perkembangan sekolah

c. Asosiasi guru-orang tua murid merupakan organisasi penting untuk meningkatkan kualitas sekolah

Jika instrumen berskala kumulatif, instrumen tersebut harus memberi peluang guna mengatur semua jawaban responden ke dalam bentuk tabel seperti berikut.

Tabel 8.1. Teknik Kumulatif

\begin{tabular}{|c|c|c|c|c|c|c|}
\hline \multirow{2}{*}{ Skor } & \multicolumn{3}{|c|}{ Setuju dengan item } & \multicolumn{3}{c|}{ Tidak setuju dengan item } \\
\cline { 2 - 7 } & 3 & 2 & 1 & 3 & 2 & 1 \\
\hline 3 & $\mathrm{X}$ & $\mathrm{X}$ & $\mathrm{X}$ & 0 & 0 & 0 \\
\hline 2 & 0 & $\mathrm{X}$ & $\mathrm{X}$ & $\mathrm{X}$ & 0 & 0 \\
\hline 1 & 0 & 0 & $\mathrm{X}$ & $\mathrm{X}$ & $\mathrm{X}$ & 0 \\
\hline 0 & - & - & - & $\mathrm{X}$ & $\mathrm{X}$ & $\mathrm{X}$ \\
\hline
\end{tabular}

Ketika membuat skala kumulatif, seorang peneliti harus menentukan, pertama, apakah semua item membentuk skala berdimensi tunggal. Untuk mencapai hal tersebut, perlu dapat menganalisis reproduksi jawaban, yaitu proporsi prediksi kemudian dibuat dengan menggunakan jawaban item-item utama. Kemudian bentuk jawaban yang sebenarnya dipelajari, dan pengukuran dibuat dengan mempertimbangkan respons yang reproduktif terhadap skor total. Skala Guttman mungkin merupakan teknik skala pengukuran yang paling populer dan banyak digunakan pada penelitian sosial.

\section{Skala Simentis}

Sikap skala dengan menggunakan skala simentis ini dikonstruksi dengan memilih kata-kata sifat yang berpasangan untuk menggambarkan dimensi evaluatif. Pasangan kata-kata sifat tersebut kemudian ditampilkan dengan tujuh skala kategori jawaban. Dalam hal ini responden diarahkan untuk memberikan tanda cross (x) dalam salah satu dari tujuh spasi yang menggambarkan keadaan paling tepat dengan sifat pilihan responden. Sebagai contoh dalam kasus ini, seandainya seorang 
peneliti ingin mengukur sikap para siswa sekolah SMK Negeri 1 Masohi terhadap lembaga sekolah mereka.

\section{Sekolah}

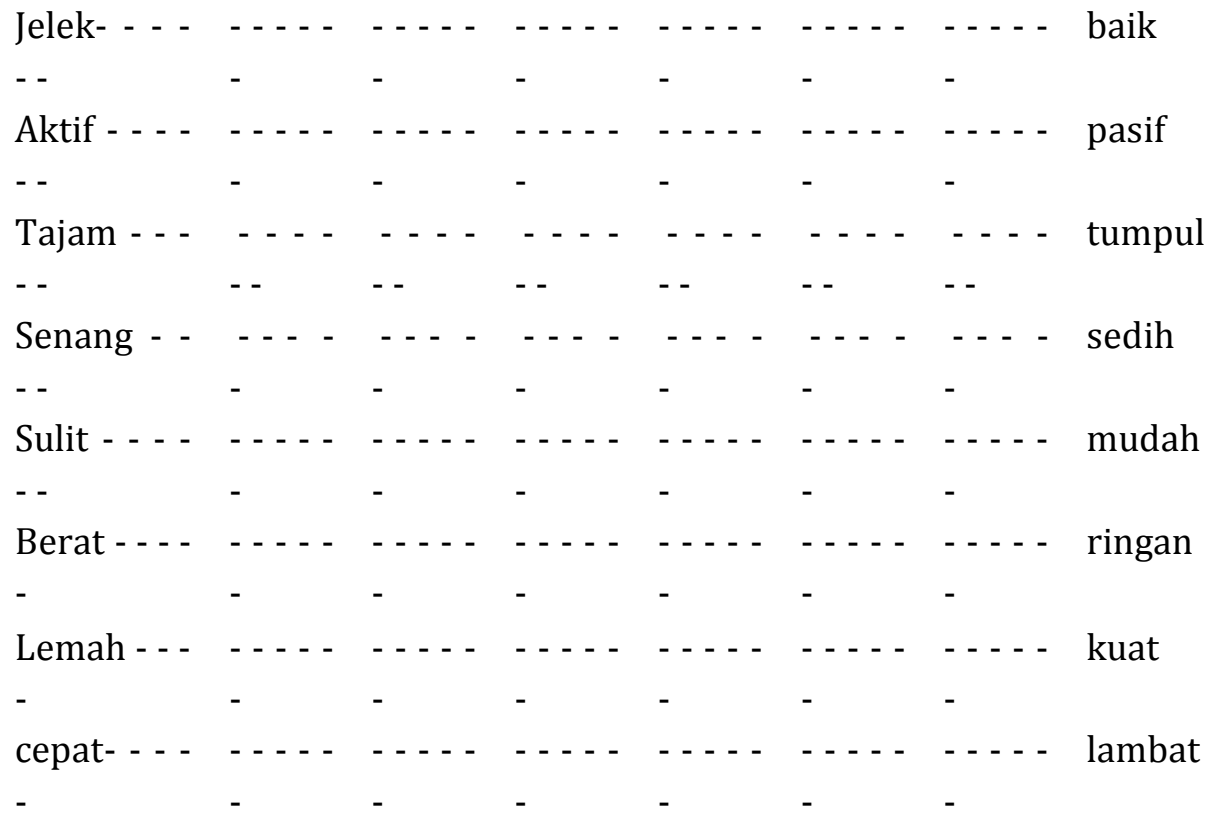

Pada gambar ini, pasangan kata sifat dibuat secara sistematis, sehingga dapat menghindari respons yang cenderung ke satu arah. Pada satu sisi tidak harus dimulai dari yang posiif. Peneliti juga dapat membuat instrumen dengan dimulai dari yang negatif. Pada kedua ujung secara sengaja dibuat tidak beraturan agar tidak membentuk pola jawaban ke satu arah saja.

\section{Skala Rating}

Skala rating telah banyak digunakan dalam penelitian di beberapa bidang ilmu seperti pendidikan, psikologi, atau bidang profesi terutama yang berkaitan dengan tingkah laku seorang maupun kelompok.

\section{TEKNIK PENGUKURAN}

Tes merupakan instrumen atau alat untuk mengukur perilaku atau kinerja seseorang dengan tujuan yang bermacam-macam sesuai dengan konteksnya seperti evaluasi, diagnostik, seleksi, penempatan, dan promosi. Tes dilakukan berdasarkan asumsi bahwa manusia mempunyai perbedaan dalam hal kemampuan, kepribadian, dan perilaku dan bahwa perbedaan tersebut dapat diukur dengan cara tertentu. Secara berurutan, uraian berikut ini akan 
difokuskan pada pembahasan sekilas tentang tes pencapaian (achievement test) yang dirancang untuk mengukur hasil belajar.

Test merupakan metode pengumpulan data penelitian yang berfungsi untuk mengukur kemampuan seseorang. Tes dapat digunakan untuk mengukur kemampuan yang memiliki respon/jawaban benar atau salah. Jawaban benar akan mendapat skor dan jawaban salah tidak mendapat skor. Dengan demikian, hasil pengukuran dengan menggunakan tes ter- masuk kategori data kuantitatif.

Ada berbagai macam kemampuan yang dapat diukur dengan menggunakan tes. Bidang ilmu psikologi banyak yang mengembangkan tes kemampuan ini untuk mengukur intelegensi, bakat, minat dan kepribadian. Dalam bidang pendidikan, tes biasa digunakan untuk mengukur prestasi belajar dan kompetensi kejuruan. Prestasi belajar dapat diukur dengan berbagai macam jenis tes, yaitu tes tertulis, tes lisan dan tes unjuk kerja. Berdasarkan bentuk jawabannya, tes prestasi belajar terdiri atas objective test dan subjective test. Objective test itu sendiri terdiri dari tes dengan jawaban pilihan ganda, benar salah dan menjodohkan.

Penggunaan tes dalam penelitian tergantung pada variabel yang diukur. Kadang-kadang peneliti tidak perlu mengembangkan perangkat tes sendiri tetapi tinggal memanfaatkan perangkat tes yang sudah dikem- bangkan oleh lembaga pengujian. Namun untuk mengukur pengetahuan tentang variabel yang spesifik, misalnya: pengetahuan tentang gizi, alat kontrasepsi, metode kerja, dll, peneliti sering harus mengembangkannya perangkat soal tes sendiri.

Ada beberapa langkah yang harus ditempuh dalam mengembangkan tes pencapaian hasil belajar, yaitu:

1) Menyusun spesifikasi tes, yaitu berisi uraian yang menunjukkan keseluruhan karakteristik yang harus dimiliki suatu tes. Penyusunan spesifikasi tes mencakup kegiatan menentukan tujuan tes, menyusun kisi-kisi tes, memilih bentuk tes, dan menentukan panjang tes.

2) Menulis soal tes.

3) Melakukan uji coba tes.

4) Menganalisis butir soal, baik secara kuantitatif maupun secara kualitatif. Secara kualitatif, yakni telaah oleh teman sejawat dalam rumpun keahlian yang sama. Telaah secara kuantitatif, yakni analisis berdasarkan hasil uji coba tes atau hasil penggunaan tes. 
5) Memperbaiki tes. Setelah butir tes ditelaah dari ranah materi, konstruksi, dan bahasa, kemudian dikelompokkan menjadi butir tes yang baik atau diterima, tidak baik atau ditolak, dan butir tes yang kurang baik, diperbaiki.

6) Merakit tes. Butir-butir yang baik ditata atau dirakit dengan cara tertentu. Dalam merakit tes, butir-butir soal dikelompokkan menurut urutan kompetensi dasar, taraf kesukaran, dan format (komposisi bentuk soal).

7) Melaksanakan tes.

8) Menafsirkan hasil tes. Agar dapat memanfaatkan hasil tes secara efektif, perlu dilakukan analisis terhadap hasil tes tersebut dengan cara, yaitu: membuat tabel spesifikasi yang menunjukkan konsep/sub konsep atau tema/sub tema kompetensi dasar mana yang belum dikuasai siswa.

\section{VALIDITAS DAN RELIABILITAS INSTRUMEN}

Dalam penelitian diperlukan instrumen-instrumen penelitian yang telah memenuhi persyaratan tertentu. Persyaratan yang harus dipenuhi oleh suatu instrumen penelitian minimal ada dua macam, yaitu validitas dan reliabilitas. Bagi instrumen tertentu seperti tes kemampuan, tes hasil belajar ditambahkan persyaratan daya pembeda dan tingkat kesulitan butir soal, bagi skala deskriptif ditambahkan daya pembeda dan normalitas sebaran respon.

\section{Validitas instrumen}

Validitas instrumen menunjukan bahwa hasil dari suatu pengukuran menggambarkan segi atau aspek yang diukur.

Beberapa karakteristik dari validitas (Sukmadinata, 2012) adalah sebagai berikut:

a. Validitas sebenarnya menunjuk kapada hasil dari penggunaan instrumen tersebut bukan pada instrumennya. Suatu instrumen dikatakan valid atau memiliki validitas bila instrumen tersebut benarbenar mengukur aspek atau segi yang diukur. Suatu tes benar-benar mengukur pengetahuan tentang nilai-nilai tersebut. Suatu skala benar-benar mengukur sikap terhadap pembaharuan bukan pengetahuan pembaharuan tersebut.

b. Validitas menunjukan suatu derajat atau tingkatan validitasnya tinggi, sedang atau rendah, bukan valid dan tidak valid.

c. Validitas instrumen juga memiliki spesifikasi tidak berlaku umum. Suatu tes matematika menunjukan validitas tinggi untuk mengukur ketrampilan menghitung, tetapi hanya sedang dalam mengukur 
kemampuan berpikir matematis, bahkan rendah dalam memprediksi keberhasilan dalam matematika untuk yang akan datang. Ada berberapa macam validitas, yaitu validitas isi, konstruk, dan kriteria.

1) Validitas isi (content validity), berkaitan dengan isi dan format dari instrumen. Apakah instrumen dapat mengukur hal yang ingin diukur, apakah butir-butir pertanyaan telah mewakili aspek-aspek yang akan diukur. Apakah pemilihan format instrumen cocok untuk mengukur segi tersebut?

2) Validitas konstruk (construct validity), berkaitan dengan konstruk atau struktur dan karakteristik psikologis aspek yang akan diukur dengan instrumen. Apakah konstruk tersebut dapat menjelaskan perbedaan kegiatan atau perilaku individu dengan aspek yang diukur.

3) Validitas kriteria (criterion validity), berkaitan dengan tingkat ketepatan instrumen mengukur segi yang akan diukur dibandingkan dengan hasil pengukuran dengan instrumen lain yang menjadi kriteria. Instrumen yang menjadi kriteri adalah instrumen yang sudah standar. Validitas kriteria dihitung dengan mengkorelasikan skor yang diperoleh dari penggunaan instrumen di lapangan, maka validitas tersebut juga bisa disebut validitas empiris. Berdasarkan hasil perhitungan korelasi dapat diperkirakan perilaku yang akan datang. Oleh karena itu, validitas kriteria disebut juga valdiitas prediksi.

\section{Reliabilitas instrumen}

Reliabilitas berkaitan dengan tingkat keajegan atau ketetapan hasil pengukuran. Suatu instrumen memiliki tingkat reliabilias yang memadai, bila instrumen tersebut digunakan mengukur aspek yang diukur beberapa kali hasilnya sama atau relatif sama. Minimal ada metode untuk menguji reliabilitas instrumen, pertama metode Tes-Retes, dan kedua metode Paruh. Dalam metode Tes-Retes pengujian (ujicoba) dilakukan dua atau tiga kali terhadap sampel yang sama. Hasilnya dihitung dengan uji korelasi menggunakan rumus Product Moment dari Pearson (Sukmadinata, 2012). Bila korelasi atau r-nya signifikan maka instrumen tersebut memiliki reliabilitas yang memadai dan bisa digunakan untuk pengukuran selanjutnya. Dalam metode paruh waktu, pengukuran ujicoba hanya dilakukan satu kali, skor dari nomor-nomor butir soal ganjil dikorelasikan dengan skor dari butir-butir genap, penafsirannya sama dengan Tes-Retes. 


\section{LEMBAR KERJA}

Petunjuk:

Mahasiswa mengkaji kembali prosedur penyusunan instrumen dan jenis-jenis instrumen menurut kegunaannya. Selanjutnya selesaikan tugas berikut.

Seorang peneliti ingin mengetahui pengaruh pendekatan Pembelajaran Matematika Realistik terhadap Kemampuan Representasi Matematis siswa kelas X SMA Kristen 1 Amahai.

1. Buatlah kisi-kisi instrumen, instrumen kemampuan representasi matematis, rubrik penyekoran tentang penelitian di atas. Yang mencakup variabel, dan indikator yang diukur.

a. Variabel yang diukur:

b. Indikator yang diukur:

2. Rumuskan butir-butir petanyaannya
a.
b.
c.

\section{RANGKUMAN}

Pengumpulan data dan pengukuran merupakan langkah yang sangat penting dalam metode ilmilah, karena pada umumnya data yang dikumpulkan digunakan untuk menguji hipotesis yang dirumuskan. Ada beberapa teknik pengumpulan data yaitu, wawancara, angket, observasi, dan studi dokumenter. Untuk melakukan pengukuran terhadap data nontes digunakan skala pengukuran yang merupakan kesepakatan yang digunakan sebagai acuan untuk menentukan panjang pendeknya interval yang ada dalam alat ukur, shingga alat ukur tersebut bila digunakan dalam pengukuran akan menghasilkan data kuantitaif. Ada beberapa macam jenis skala yang dapat diterapkan dalam penelitian pendidikan khususnya maupun pendidikan tingkah laku pada umumnya. Beberapa skala tersebut yaitu skala Likert, skala Thurstone, skala Guttman, skala Simentis, skala Rating.

Tes merupakan instrumen atau alat untuk mengukur perilaku atau kinerja seseorang dengan tujuan yang bermacam-macam sesuai dengan konteksnya seperti evaluasi, diagnostik, seleksi, penempatan, dan promosi. Tes dilakukan berdasarkan asumsi bahwa manusia mempunyai perbedaan dalam hal kemampuan, kepribadian, dan perilaku dan bahwa perbedaan tersebut dapat diukur dengan cara tertentu.

Persyaratan yang harus dipenuhi oleh suatu instrumen penelitian minimal ada dua macam, yaitu validitas dan reliabilitas. Bagi instrumen tertentu seperti 
tes kemampuan, tes hasil belajar ditambahkan persyaratan daya pembeda dan tingkat kesulitan butir soal, bagi skala deskriptif ditambahkan daya pembeda dan normalitas sebaran respon.

\section{TUGAS}

1. Tugas bagi mahasiswa yang melakukan teknik pengumpulan data dengan non-tes (wawancara, angket, observasi, dan studi dokumenter)

a) Mengadospi angket yang sudah diseminarkan atau membuat lembar pengamatan terstruktur dengan menggunakan pedoman yang berisi tentang karakteristik apa yang harus diamati

b) Dari instrumen tes yang dibuat kemudian dilakukan uji Validitas dan Reliabilitas pada kelompok kecil (di sekolah, tempat les, kelompok belajar)

c) Membuat interpretasi dari hasil pengujian Validitas dan Reliabilitas

2. Uraikan secara jelas analisis Anda prosedur yang dapat dilakukan oleh peneliti untuk meningkatkan keakuratan teknik observasi langsung yang digunakan. Buatlah dalam bentuk makalah dengan bagian pokok yang harus ada adalah Pendahuluan, Isi, dan Kesimpulan.

3. Tugas bagi mahasiswa yang melakukan teknik pengukuran data dengan tes (tes hasil belajar matematika atau tes kemampuan matematika)

a) Menyusun kisi-kisi tes (berdasarkan Silabus dan RPP) dan membuat instrumen sebagai bahan dalam penyusunan proposal penelitian masing-masing.

b) Dari instrumen tes yang dibuat kemudian dilakukan uji Validitas dan Reliabilitas pada kelompok kecil (di sekolah, tempat les, kelompok belajar)

c) Membuat interpretasi dari hasil pengujian Validitas dan Reliabilitas 


\section{BAB 9 \\ ANALISIS DATA}

0 etelah data dalam penelitian terkumpul, langkah berikutnya yang harus dilakukan oleh peneliti adalah melakukan pengolahan/analisis data. Pada prinsipnya analisis data ada dua cara dilihat dari jenis datanya, yaitu analisis non statistik dan analisis statistik. Analisis non statistik dilakukan terhadap data kualitatif. Data yang dikumpulkan bukanlah secara random atau mekanik, tetapi dikuasai oleh pengembangan hipotesis. Apa yang ditemukan pada suatu saat adalah satu pedoman yang langsung terdapat apa yang akan dikumpulkan berikutnya dan di mana akan dicari. Analisis statistik berangkat dari data kuantitatif. Pada bab ini akan dibicarakan tentang pengolahan data kuantitatif dengan teknik statistik. Kemampuan akhir yang diharapkan setelah mahasiswa mempelajari bab ini yaitu:

1. Merancang cara untuk menganalisis dan menginterpretasikan data sebagai bahan dalam penyusunan proposal penelitian

2. Membaca dan mengevaluasi penelitian yang dipublikasikan di bidang pendidikan

3. Menganalisis data penelitian non statistik dan analisis data statistik

4. Menginterpretasikan data sebagai bahan dalam penyusunan proposal penelitian

\section{A. PENGANTAR STATISTIKA}

Penelitian kuantitatif mengandalkan angka-angka dalam laporan tentang pemilihan subyek, hasil, dan dalam mengestimasi reliabilitas dan validitas instrumen. Angka-angka yang digunakan bersama simbol-simbol dan istilah khusus yang dimanipulasi dalam laporan tersebut dinamakan data kuantitatif. Statistik merupakan cara-cara tertentu yang ditempuh dalam rangka mengumpulkan, menyusun/mengatur, menyajikan, menganalisis dan memberi interpretasi terhadap sekumpulan bahan keterangan yang berupa angka sehingga "dapat berbicara" atau memberikan pengertian dan makna tertentu. Dengan kata lain, statistik adalah metode untuk mengorganisasikan dan menganalisis data-data kuantitatif yang dikumpulkan melalui pengukuran.

Pada umumnya statistik dibagi dua, yaitu statistik deskriptif (statistik deduktif/statistik sederhana) dan statistik inferensial (statistik induktif/statistik lanjut/statistik mendalam). Statistik deskriptif memiliki tugas mengorganisasi \& menganalisis data angka, agar memberi gambaran secara teratur, ringkas dan jelas mengenai suatu gejala, peristiwa atau keadaan, sehingga dapat ditarik pengertian atau makna tertentu. Statistik 
inferensial adalah statistik yang menyediakan aturan/cara yang dapat dipergunakan sebagai alat dalam rangka mencoba menarik kesimpulan yang bersifat umum, dari sekumpulan data yang telah disusun dan diolah. Statistik inferensial menyediakan pula aturan tertentu dalam rangka penarikan kesimpulan (conclusion), penyusunan atau pembuatan ramalan (prediction), penaksiran (estimation) dan lain-lain.

Untuk memahami lebih jauh tentang perbedaan antara statistik deskriptif dan inferensial, perhatikan contoh pernyataan berikut. Mana yang tampaknya "deskriptif" dan mana yang "inferensial"?

1) Mahasiswa program $S 1$ di Universitas $X$ rata-rata menyelesaikan studinya selama $51 / 2$ tahun.

2) Semakin banyak variasi pembelajaran yang diciptakan oleh guru di kelas yang heterogen, semakin baik hasil belajar yang dicapai oleh siswa.

3) Sekitar $90 \%$ dari siswa yang belajar di sekolah favorit adalah putera pejabat atau orang-orang kaya.

4) Setiap tahun hanya sekitar $60 \%$ lulusan SD dan sederajat yang melanjutkan ke SMP.

5) Kita dapat berharap bahwa masukan siswa yang mempunyai kemampuan intelektual tinggi akan menghasilkan lulusan yang mutunya terjamin.

Pernyataan 1, 3, 4 adalah deskriptif karena memberikan deskripsi dan ringkasan dari hasil observasi. Sedang pernyataan 2 dan 5 menjangkau apa yang ada dibalik observasi untuk membuat kesimpulan (inferensi) tentang apa yang mungkin terjadi.

\section{B. STATISTIK DESKRIPTIF}

\section{1) Ukuran tendensial sentral}

Ukuran tendensial sentral adalah nilai angka tunggal yang digunakan untuk mendeskripsikan rata-rata atau untuk mewakili skor dari seluruh sampel. Ada tiga macam yang banyak digunakan adalah mean (nilai rata-rata dari seluruh sampel), median (nilai tengah yang membagi sampel menjadi dua), dan modus (nilai yang paling banyak muncul di antara yang diperoleh sampel).

\section{2) Pengukuran variabilitas}

Ukuran yang dapat memberikan informasi tentang arahperbedaan atau penyebaran skor individual dalam kelompok disebut ukuran variabilitas. Ada beberapa teknik yang dapat digunakan untuk mengukur variabilitas, yaitu: range/rentang (jarak antara nilai yang 
tertinggi dan terendah), standar deviasi (memberikan gambaran tentang homogenitas skor sampel), varian (menggambarkan variabilitas nilai variabel tunggal), dan kovarian (menggambarkan variabilitas nilai variabel yang berinteraksi).

\section{STATISTIK INFERENSIAL}

\section{1) Probabilitas}

Probabilitas adalah suatu cara ilmiah untuk menyatakan tingkat kepastian yang kita miliki saat menebak/memperkirakan sesuatu. Dalam statistik, probabilitas diartikan sebagai jumlah kasus kejadian yang favorabel dibagi dengan seluruh kasus. Jika seluruh kasus ada 10 dan jumlah kasus yang favorabel ada 5, maka probabilitas kasus yang favorabel adalah 5/10 atau 0,50. Pengocokan dadu adalah contoh yang lebih kongkret. Dengan satu mata dadu, ada 6 kasus yang mungkin muncul. Bila kasus yang menguntungkan ada pada angka 4, maka kemungkinan munculnya angka 4 adalah $1 / 6$ atau 0,17, sehingga bila dadu dikocok 100 kali, sekitar 17 kali angka 4 akan muncul. Probabilitas kejadian yang tidak mungkin adalah 0 (nol), sebab tidak akan ada hasil yang memenuhi syarat terwujudnya kejadian tersebut. Probabilitas munculnya semua hasil dari semua yang mungkin adalah 1,0, sebab seluruh kejadian yang mungkin berhasil muncul semuanya. Karena itulah probalilitas suatu kejadian akan berada antara 0 dan 1 .

\section{2) Hipotesis Nol}

Hipotesis nol digunakan untuk menguji asumsi bahwa tidak ada perbedaan antar nilai populasi, artinya mean populasinya sama. Peneliti menggunakan statistik inferensial untuk menentukan kemungkinan bahwa hipotesis nol tidak benar. Bila salah maka besar kemungkinan ada perbedaan antar nilai populasi. Hipotesis nol pada contoh ini misalnya prilaku siswa kelas enam dan empat adalah sama. Bila kita dapat menunjukkan ada probabilitas yang tinggi dalam menolak hipotesis nol, maka kita telah menemukan bukti perbedaan pada prilaku siswa.

\section{3) Taraf signifikansi}

Taraf signifikansi (p) dipakai untuk menunjukkan bagaimana peluang bahwa kita salah dalam menolak hipotesis nol. Taraf signifikansi berupa desimal yang menunjukkan berapa kemungkinan kita salah dari seratus atau seribu peluang dalam menolak hipotesis nol dengan asumsi bahwa hipotesis nol itu benar. 
Bila kita menemukan bahwa hanya ada satu kemungkinan dari seratus hal, maka kita akan menemukan perbedaan tertentu dalam mean dengan pola peluang $(p=0,01)$ sehingga kita bisa menolak hipotesis nol sebab ia dapat saja salah. Semakin rendah tingkat signifikansi, semakin besar kepastian yang kita miliki untuk menolak hipotesis nol.

Berapa taraf signifikansi yang dapat dijadikan sebagai kriteria diterima atau ditolaknya hipotesis nol sangat tergantung pada seberapa besar peneliti mau menerima resiko terjadinya kesalahan. Dalam penelitian pendidikan, taraf signifikansi atau probabilitas yang biasa ditetapkan adalah $10 \%(\mathrm{p}=0,10), 5 \%(\mathrm{p}=0,05)$, atau $1 \%$ $(p=0,01)$, meskipun tidak selalu secara eksplisit dinyatakan oleh peneliti. Ada beberapa kaidah tentang penafsiran hasil uji hipotesis dengan ketentuan: 1) jika $\mathrm{p} \leq 0,01$ hasilnya dinyatakan sangat signifikan; 2) jika $\mathrm{p} \leq 0,05$ hasilnya dinyatakan signifikan; 3) jika $\mathrm{p}$ $\geq 0,05$ hasilnya dinyatakan tidak signifikan.

Sebagai contoh, dalam kasus penelitian tentang perbedaan nilai IPS siswa yang diajar dengan metode ceramah dan diskusi ditetapkan bahwa hipotesis akan diterima pada taraf signifikansi 5\%. Ini berarti bahwa jika hasil perhitungan uji signifikansi menunjukkan angka yang sama atau lebih kecil dari $p=0,05$, maka hasilnya signifikan. Hipotesis nol ditolah, sehingga dapat disimpulkan ada perbedaan nilai yang berarti antara kedua kelompok yang diajar dengan metode yang berbeda.

\section{4) Analisis korelasional Analisis}

korelasional merupakan teknik untuk menguji hubungan antara dua variabel atau lebih. Hubungan tersebut menunjukkan variasi kemunculan nilai suatu variabel dalam kaitannya dengan variasi nilai variabel yang lain. Hubungan tersebut dalam digambarkan dalam bentuk grafik, dan nilai koefisien (angka yang merentang dari $-1,0$ sampai $+1,0)$.

Ada beberapa teknik statistik yang dapat digunakan untuk analisis korelasional, di antaranya: Product Moment, Rank Spearman, Biserial, Point Biserial, Koefisien kontingensi, Tau Kendall, dan Koefisien Kontingensi, Analisis Regresi dan lain-lain. Untuk menentukan jenis analisis korelasional yang tepat dalam sebuah penelitian, terlebih dahulu harus dilihat jenis data dari 
variabel-variabel yang diteliti. Sebagai panduan, Tabel 9.1. disajikan berbagai jenis analisis korelasional berdasarkan skala datanya.

Banyak sekali teknik analisis statistik yang dapat digunakan untuk analisis korelasional ini, baik statistik parametrik maupun nonparametrik. Penggunaan masing-masing teknik analisis tersebut sangat tergantung pada jenis skala datanya. Skala data terdiri dari:

a) Data nominal, yaitu data kualitatif yang tidak memiliki jenjang. Contoh jenis kelamin, asal daerah, pekerjaan orang tua, hobby, dan sebagainya.

b) Data ordinal, yaitu data kualitatif yang memiliki jenjang, seperti tingkat pendidikan, jabatan, pangkat, ranking kelas, dan sebagainya.

c) Data interval/rasio, yaitu data kuantitatif atau data yang berupa angka atau dapat diangkakan. Contoh penghasilan, prestasi belajar, tinggi badan, tingkat kecerdasan, volume penjualan, dan sebagainya.

\begin{tabular}{|c|c|c|c|c|}
\hline \multirow{2}{*}{\multicolumn{2}{|c|}{$\begin{array}{c}\text { Varibel dan } \\
\text { Skala }\end{array}$}} & \multicolumn{3}{|c|}{ Variabel Dependen/Terikat } \\
\hline & & Nominal & Ordinal & Interval \\
\hline \multirow{3}{*}{ 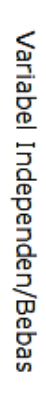 } & Nominal & $\begin{array}{l}\text { - Koefisien } \\
\text { kontingensi }\end{array}$ & & $\begin{array}{l}\text { - Korelasi Serial } \\
\text { - Regresi dengan } \\
\text { variabel dummy }\end{array}$ \\
\hline & Ordinal & & $\begin{array}{l}\text { - Rank } \\
\text { Spearman } \\
\text { - Tau Kendall }\end{array}$ & \\
\hline & Interval & $\begin{array}{l}\text { - Discriminant } \\
\text { Analysis }\end{array}$ & & $\begin{array}{l}\text { - Korelasi product } \\
\text { moment } \\
\text { - Korelasi parsial } \\
\text { - Korelasi semi } \\
\text { parsial } \\
\text { - Analisis Regresi }\end{array}$ \\
\hline
\end{tabular}

Tabel 9. 1. Berbagai jenis analisis korelasional berdasarkan skala data (Hasnunidah, 2017)

\section{5) Analisis Komparasi Analisis}

komparasi adalah teknik analisis statistik yang bertujuan untuk membandingkan antara kondisi dua buah kelompok atau lebih. Teknik analisis yang digunakan juga cukup banyak, penggunaan teknik analisis tersebut tergantung pada jenis skala data dan banyak sedikitnya kelompok. Sebagai panduan, Tabel 10.2. disajikan berbagai jenis analisis komparasi berdasarkan skala datanya. 


\begin{tabular}{|c|c|c|c|c|}
\hline \multirow{2}{*}{\multicolumn{2}{|c|}{$\begin{array}{c}\text { Jumlah } \\
\text { Kelompok }\end{array}$}} & \multicolumn{3}{|c|}{ Variabel Dependen/Terikat } \\
\hline & & \multirow{2}{*}{\begin{tabular}{l}
\multicolumn{1}{c}{ Nominal } \\
$\cdot$ Kai Kuadrat \\
$\cdot$ Kolmogorov- \\
Smirnov
\end{tabular}} & \multirow[b]{2}{*}{\begin{tabular}{ll} 
& \multicolumn{1}{c}{ Ordinal } \\
- & Mann-Whitney U \\
- & Kolmogorov- \\
- Smirnov \\
- & Kai Kuadrat
\end{tabular}} & \multirow{2}{*}{$\begin{array}{l}\text { Interval } \\
\text { - Separate t-test } \\
\text { - Pooled t-test }\end{array}$} \\
\hline $\begin{array}{l}\text { N } \\
\text { 중 } \\
\text { 잉 }\end{array}$ & 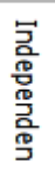 & & & \\
\hline 큼 & 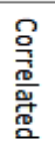 & & $\begin{array}{l}\text { - Wilcoxon } \\
\text { - McNernar } \\
\text { - Sign Test }\end{array}$ & $\begin{array}{l}\text { Paired/corelated } \\
\text { t-test }\end{array}$ \\
\hline 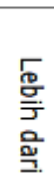 & $\begin{array}{l}\text { 容 } \\
\text { 总 } \\
\text { 高 } \\
\text { 总 }\end{array}$ & $\begin{array}{ll} & \text { Kai Kuadrat } \\
\text { - } & \text { Kolmogorov- } \\
\text { - } & \text { Smirnov }\end{array}$ & $\begin{array}{l}\text { - Kruskall-Wallis } \\
\text { - Uji Median } \\
\text { - Kai Kuadrat }\end{array}$ & $\begin{array}{l}\text { Analisis Varians } \\
\text { (ANAVA) }\end{array}$ \\
\hline $\begin{array}{l}\text { 중 } \\
\frac{\mathrm{0}}{\mathrm{O}} \\
\frac{3}{\mathrm{~g}} \\
\text { 뭇 }\end{array}$ & $\frac{2}{\frac{2}{3}}$ & & $\begin{array}{l}\text { - Friedman } \\
\text { - Kendall's W } \\
\text { - Cochran's Q }\end{array}$ & $\begin{array}{l}\text { ANAVA repeat } \\
\text { measures }\end{array}$ \\
\hline
\end{tabular}

Tabel 9.2. Teknik analisis komparasi berdasarkan jenis skala data dan banyak sedikitnya kelompok (Hasnunidah, 2017)

Ada dua macam teknik yang dapat digunakan, yaitu uji t-sampel independen dan uji-t sampel dependen. Uji-t independen digunakan bila skor kedua kelompok tidak berhubungan satu sama lain. Skor yang diperoleh tersebut berasal dari dua sampel atau kelompok subyek yang berbeda dari populasi yang berbeda pula. Misalnya, perbandingan antara skor atau nilai IPA yang diperoleh siswa pria dan wanita. Dikatakan endependen karena skor yang diperoleh siswa pria siswa tidak tergantung pada apa yang diperoleh siswa wanita. Sedangkan uji-t dependen, disebut berpasangan dan berkorelasi, digunakan bila skor yang diperoleh dalam kedua kelompok berasal dari subyek yang sama. Misalnya, perbandingan skor IPA dan IPS yang diperoleh oleh satu kelompok siswa. Peneliti melibatkan dua observasi terhadap kelompok yang sama.

Pengujian hipotesis dilakukan dengan cara membandingkan nilai $\mathrm{t}$ dari perhitungan atau observasi dengan nilai $t$ yang ada dalam tabel distribusi $t$ dan taraf signifikansi tertentu. Bila nilai yang diperoleh $t$ lebih kecil dari nilai nilai t tabel, hipotesis nol diterima, berarti tidak ada perbedaan nilai rata-rata yang cukup berarti antara kedua kelompok. 
a. Membandingkan Dua Mean: Uji-t

Uji-t adalah sebuah rumus yang menghasilkan angka-angka yang digunakan untuk menentukan tingkat probabilitas (p) penolakan hipotesis. Keduanya mempunyai nilai yang berlawanan arah, yakni bila jumlah subyeknya sama, semakin besar nilai $t$, semakin kecil nilai $p$ dan berarti semakin tinggi tingkat signifikansinya.Penggunaan uji-t didasarkan pada asumsi tentang skor yang diperoleh dalam penelitian, yaitu: skor yang diperoleh berbentuk kontinum, skor dari populasi yang diteliti tersebar normal, dan variansi skor populasi yang diteliti sama.

b. Membandingkan Dua Mean Atau Lebih: Analisis Varian

1) Analisis varian satu faktor

Anava merupakan teknik statistik inferensial yang mengevaluasi apakah ada perbedaan sisitematis di antara mean dari sejumlah kelompok yang berbeda. Anava 1 X 3, berarti ada 1 variabel bebas/faktor dan 3 kelompok/tingkat. Angka pertama menunjukkan jumlah variable bebas, disebut faktor, dan angka kedua menunjukkan jumlah kelompok atau tingkat (level). Karena hanya ada satu variable bebas, maka disebut juga Anava satu jalur atau satu faktor. Untuk menguji hipotesis, Anava menggunakan $\mathrm{F}$ yang analogi dengan $\mathrm{t}$. Nilai $\mathrm{F}$ hitung dibandingkan dengan nilai yang ada pada tabel F. Jika nilai $\mathrm{F}$ hitung $<\mathrm{F}$ tabel, maka hipotesis diterima, berarti tidak ada perbedaan nilai rata-rata yang signifikan antar masing-masing kelompok subyek.

Anava digunakan untuk menguji hipotesis nol bahwa mean dari semua kelompok populasi tidak berbeda. Jika hipotesis nol ditolak berarti tidak semua mean sama. Kemudian untuk menguji mean mana yang berbeda digunakan perbandingan ganda (post hoc comparison/multiple comparison). Ada beberapa teknik perbandingan ganda yang telah dikembangkan oleh para ahli statistik, diantaranya adalah Tukey, Fisher, Dunnet, Newman-Keuls, dan sebagainya. Teknik Tukey dianggap paling konservatif sedang teknik Fisher paling liberal, sehingga kedua teknik ini paling banyak digunakan. 
2) Faktorial analisis varian

Faktorial Anava digunakan untuk menguji perbedaan mean bila faktornya terdiri dari dua atau lebih. Anava $2 \mathrm{X}$ $2 \mathrm{X} 3$, angka pertama menunjukkan jumlah faktor, kedua dan ketiga masing-masing menunjukkan jumlah kelompok yang ada dalam faktor pertama dan kedua. Misalnya, faktor (A dan B) mempunyai dua dan tiga kelompok (A1, A2, dan B1, B2, B3). Analisis faktorial memungkinkan pengujian pengaruh interaksi antar faktor. Pengujian hipotesis diawali dengan penghitungan nilai $\mathrm{F}$ untuk masing-maing faktor dan masing-masinf tingkat interaksi. Selanjutnya membandingkan nilai F dari penghitungan dengan nilai F yang ada di tabel F. Bila nilai yang diperoleh $\mathrm{F}$ lebih kecil dari nilai $\mathrm{F}$ tabel, hipotesis nol diterima, berarti tidak ada perbedaan nilai rata-rata yang cukup berarti antar masing-masing pasangan kelompok subyek.

Petunjuk:

\section{KASUS}

Mahasiswa mengkaji kembali langkah prosedur pengolahan data dab analisis data, serta dasar-dasar statistik yang dipergunakan untuk pengujian hipotesis. Selanjutnya selesaikan soal berikut ini.

Seorang peneliti mengajukan hipotesis sebagai berikut: tidak ada pengaruh antara metode diskusi dan metode ceramah terhadap prestasi belajar matematika siswa kelas XII SMA Negeri 1 Amahai.

Data menunjukan:

Pada kelompok eksperimen nilai hasil tes pada akhir eksperimen adalah sebagai berikut.

\begin{tabular}{|l|l|l|l|l|}
\hline 50 & 58 & 58 & 63 & 63 \\
\hline 65 & 69 & 72 & 74 & 78 \\
\hline
\end{tabular}

Pada kelompok kontrol nilai hasil tes pada akhir eksperimen adalah sebagai berikut.

\begin{tabular}{|l|l|l|l|l|}
\hline 49 & 52 & 61 & 65 & 66 \\
\hline 75 & 78 & 80 & 81 & 83 \\
\hline
\end{tabular}

Tugasnya: lakukan pengujian (uji t) dengan taraf signifikansi 5\%. 


\section{RANGKUMAN}

Statistik merupakan metode untuk mengorganisasikan dan menganalisis data-data kuantitatif yang dikumpulkan melalui pengukuran. Ada dua macam statistik, yaitu deskriptif, yang digunakan untuk meringkas dan mendeskripsikan data yang dikumpulkan melalui sampel, serta inferensial yang digunakan untuk memahami kenyataan yang ada dalam populasi berdasarkan informasi yang diperoleh melalui sampel. Statistik deskriptif diantaranya adalah ukuran tendensi sentral (mean, median, dan modus), ukuran penyebaran nilai, dan ukuran relasional. Statistik inferensial memperkirakan probabilitas karakteristik populasi dalam rentang kepercayaan tertentu, diantaranya pengujian perbedaan mean (Uji-t dan Anava).

\section{TUGAS}

1. Setelah Anda melakukan uji Validitas dan Reliabilitas terhadap alat ukur (instrumen), menguji instrumen tersebut pada kelompok kecil, langkah selanjutnya adalah melakukan teknik analisis data pada penelitian yang relevan dengan pendekatan penelitian yang digunakan. 


\section{BAB 10 MENYUSUN PROPOSAL PENELITIAN}

$\mathrm{K}$ emampuan menyusun proposal penelitian sangat penting untuk merencanakna dan mengusulkan suatu kegiatan penelitian. Secara umum ada aturan-aturan, baik yang bersifat metodologis maupun tekniks dalam meyusun proposal. Aturan-aturan itu pada umumnya bersifat universal, meskipun untuk hal-hal tertentu yang bersifat teknis ada yang harus disesuaikan dengan kebutuhan lembaga-lembaga tertentu. Dalam kaitannya dengan penyelesaian studi di perguruan tinggi, penyusunan proposal penelitian adalah langkah awal tatkala seorang mahasiswa bermaksud menyusun tugas akhir untuk memperoleh gelar akademik. Melihat begitu pentingnya proposal penelitian, maka pada bab ini akan dibicarakan tentang menyusun proposal penelitian dengan pendekatan kuantitatif dan kualitatif pada bidang pendidikan. Kemampuan akhir yang diharapkan setelah mahasiswa mempelajari bab ini yaitu:

1. Menemukan masalah dalam bidang pembelajaran matematika

2. Memilih metode penelitian berdasarkan masalah penelitian

3. Merancang proposal penelitian

\section{A. PROPOSAL PENELITIAN KUANTITATIF}

Rancangan atau proposal merupakan pedoman yang berisi langkah-langkah yang akan diikuti oleh peneliti untuk melakukan penelitiannya. Dalam menyusun rancangan penelitian, perlu diantisipasi tentang berbagai sumber yang dapat digunakan untuk mendukung dan yang menghambat terlaksananya penelitian. Penelitian dilakukan berangkat dari adanya suatu permasalahan. Masalah merupakan penyimpangan dari apa yang seharusnya dengan apa yang terjadi, penyimpangan antara rencana dengan pelaksanaan, penyimpangan antara teori dengan pelaksanaan. Rancangan penelitian harus dibuat secara sistematis dan logis sehingga dapat dijadikan pedoman yang betul-betul mudah diikuti. Rancangan penelitian yang sering disebut proposal penelitian paing tidak berisi empat komponen utama, yaitu Permasalahan, Landasan, Teori, dan Pengajuan Hipotesis, Metode Penlitian, Organisasi dan Jadwal Penelitian. Proposal penelitian kuantitatif dikemas dalam sistematika seperti ditunjukan pada gambar 10.1 . 


\section{PENDAHULUAN}

\section{a. Latar Belakang Masalah}

Pada bagian ini berisi tentang sejarah dan peristiwa-peristiwa yang sedang terjadi pada suatu obyek penelitian, tetapi dalam peristiwa itu, sekarang ini tampak ada penyimpangan-penyimpangan dari standar yang ada, baik standar yang bersifat keilmuan maupun aturan-aturan. Oleh karena itu dalam latar belakang ini, peneliti harus melakukan analisis masalah, sehingga permasalahan menjadi jelas. Melalui analisis masalah ini, peneliti harus dapat menunjukan adanya suatu penyimpangan yang ditunjukan dengan data dan menuliskan mengapa hal ini perlu diteliti

\section{b. Identifikasi Masalah}

Dalam kegiatan ini perlu dituliskan berbagai masalah pada obyek yang diteliti. Semua masalah dalam obyek, baik yang akan diteliti maupun tidak akan diteliti sedapat mungkin dikemukakan.

Untuk dapat mengidentifikasi masalah dengan baik, maka peneliti perlu melakukan studi pendahuluan ke obyek yang diteliti, melakukan observasi, dan wawancara ke berbagai sumber, sehingga semua permasalahan dapat diidentifikasikan. 


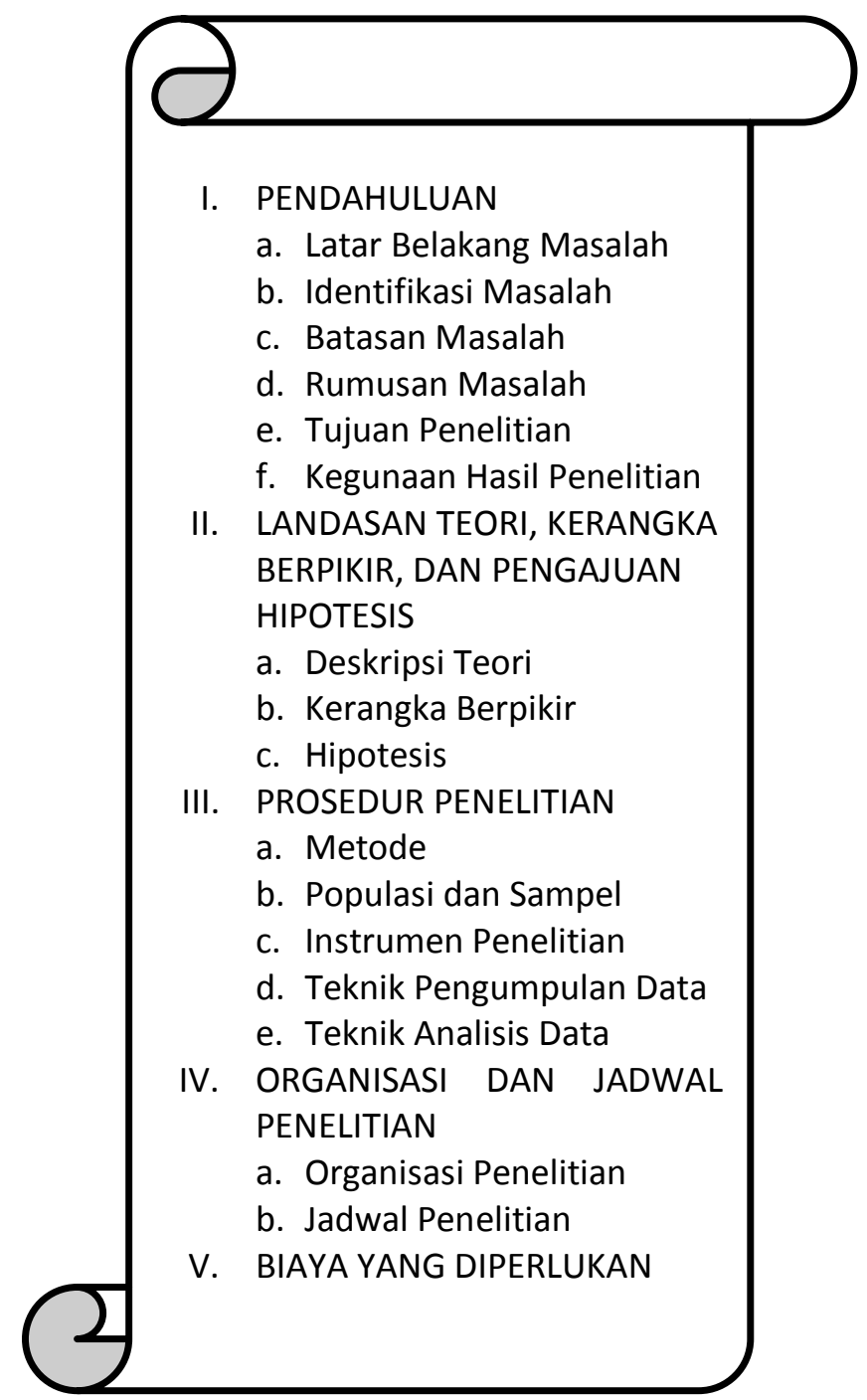

Gambar 10. 1. Sistematika proposal Penelitian Kuantitatif

Berdasarkan berbagai permasalahan yang telah diketahui tersebut, selanjutnya dikemukakan hubungan satu masalah dengan masalah yang lain. Masalah yang akan diteliti itu kedudukannya dimana di antara masalah yang akan diteliti. Masalah apa saja yang diduga berpengaruh positif dan negatif terhadap masalah yang diteliti. Selanjutnya masalah tersebut dapat dinyatakan dalam bentuk variabel.

\section{c. Batasan Masalah}

Karena adanya keterbatasan, waktu, dana, tenaga, teori-teori, dan supaya penelitian dapat dilakukan secara lebih mendalam, maka tidak semua masalah yang telah diidentifikasikan akan diteliti. Untuk itu 
maka peneliti memberi batasan, dimana akan dilakukan penelitian, variabel apa saja yang akan diteliti, serta bagaiman hubungan variabel satu dengan variabel yang lain.

Berdasarkan batasan masalah ini, maka selanjutnya dapat dirumuskan masalah penelitian.

\section{d. Rumusan Masalah}

Setelah masalah yang akan diteliti ditentukan (variabel apa saja yang akan diteliti, dan bagaimana hubungan variabel satu dengan yang lain), dan supaya masalah dapat menjawab secara akurat, maka masalah yang akan diteliti itu perlu dirumuskan secara spesifik. Seperti telah diuraikan dalam bab masalah penelitian, sebaikanya rumusan masalah itu dinyatakan dalam kalimat pertanyaan. Jadi pola pikir dalam merumuskan masalah itu ada empat tahapan yang dapat digambarkan seperti pada gambar berikut.

\section{Latar Belakang Masalah}

Berisi tentang sejarah dan peristiwa yang terjadi pada obyek yang akan diteliti, tetapi peristiwa itu nampaknya ada penyimpangan dari standar keilmuan maupun aturan. Penyimpangan ini perlu ditunjukkan dalam data. Peneliti juga perlu menuliskan mengapa hal itu perlu diteliti.

\section{Identifikasi Masalah}

Semua masalah yang ada pada obyek penelitian dikemukakan, baik masalah yang akan diteliti maupun tidak diteliti. Tunjukkan hubungan masalah satu dengan masalah yang lain. Masalah yang diteliti umumnya merupakan variabel dependen.

\section{Batasan Masalah}

Karena keterbatasan waktu, dana, tenaga, teori, dan supaya penelitian lebih mendalam maka penelitian dibatasi pada beberapa variabel saja. 


\section{Rumusan Masalah}

Dinyatakan dalam kalimat tanya, jelas, dan spesifik. Dapat berbentuk rumusan masalah deskriptif, komparatif, dan asosiatif.

Gambar 10.2. Pola Pikir dalam merumusakan Masalah

e. Tujuan Penelitian

Tujuan dan kegunaan penelitian sebenarnya dapat diletakan di luar pola pikir dalam merumuskan masalah. Tetapi keduanya ada kaitannya dengan permasalahan, oleh karena itu dua hal ini ditempatkan pada bagian ini. Tujuan penelitian disini tidak sama dengan tujuan yang ada pada sampul skripsi atau tesis, yang merupakan tujuan formal (misalnya untuk memenuhi salah satu syarat untuk mendapat gelar sarjana), tetapi tujuan ini berkaitan dengan tujuan peneliti dalam melakukan penelitian. Tujuan penelitian berkaitan erat dengan rumusan masalah yang dituliskan. Misalnya rumusan masalahnya Bagaimana tingkat disiplin guru di Sekolah A?. Maka tujuan penelitiannya adalah ingin mengetahui seberapa tinggi tingkat disiplin guru di Sekolah A. Rumusan masalahnya apakah ada pengaruh latihan terhadap produktivitas kerja pegawai, maka tujuan penelitiannya adalah ingin mengetahui apakah pengaruh latihan terhadap produktivitas kerja pegawai, dan jika ada seberapa besar. Rumusan masalah dan tujuan penelitian ini jawabannya terletak pada kesimpulan penelitian.

f. Kegunaan Hasil Penelitian

Kegunaan hasil penelitian merupakan dampak dari tercapainya tujuan. Dengan demikian tujuan penelitian dapat tercapai, dan rumusan masalah dapat terjawab secara akurat maka sekarang kegunaannya apa. Kegunaan hasil penelitian ada dua hal yaitu:

1) Kegunaan untuk mengembangkan ilmu/ keguaan teoritis

2) Kegunaan praktis, yaitu membantu memecahkan dan mengantisipasi masalah yang ada pada obyek yang diteliti 


\section{LANDASAN TEORI, KERANGKA BERPIKIR, DAN PENGAJUAN HIPOTESIS}

a. Deskripsi Teori

Deskripsi terori adalah, teori-teori relevan yang dapat digunakan untuk menjelaskan tentang variabel yang akan diteliti, serta sebagai dasar untuk memberi jawaban sementara terhadap rumusan masalah yang diajukan (hipotesis), dan penyusunan instrumen penelitian.

Teori-teori yang digunakan bukan sekedar pendapat dari pengarang, pendapat penguasa, tetapi teori yang betul-betul telah teruju kebenarannya secara empiris. Disini juga diperlukan dukungan hasil-hasil penelitian yang telah ada sebelumnya yang ada kaitannya dengan variabel yang akan diteliti. Jika variabel yang diteliti ada lima, maka jumlah teori yang dikemukakakn juga ada lima.

b. Kerangka Berpikir

Kerangka berpikir merupakan model konseptual tentang bagaimana teori hubungan dengan berbagai faktor yang telah diidentifikasi sebagai masalah yang penting.

Kerangka berpikir yang baik akan menjelaskan secara teoritis pertautan antar variabel yang akan diteliti. Jadi secara teoritis perlu dijelaskan hubungan antar variabel independen dan dependen. Bila dalam penelitian ada variabel moderator dan intervening, maka perlu juga dijelaskan, mengapa variabel ini ikut dilibatkan dalam penelitian. Pertautan antar variabel tersebut, selanjutnya dirumuskan ke dalam bentuk paradigma penelitian. Oleh karena itu pada setiap penyusunan paradigma penelitian harus didasarkan pada kerangka berpikir.

Kerangka berpikir dalam suatu penelitian perlu dikemukakan apabila dalam penelitian tersebut berkaitan dua variabel atau lebih. Apabila peneliti hanya membahas sebuah variabel atau lebih secara mandiri, maka yang dilakukan peneliti disamping mengemukakan deskripsi teoritis untuk masing-masing variabel, juga argumentasi terhadap variasi besaran yang diteliti.

Kerangka berpikir yang dihasilkan dapat berupa kerangka berpikir yang asosiatif/hubungan maupun komparatif perbandingan. Kerangka berpikir yang asosiatif dapat menggunakan kalimat: jika begini maka akan begitu; jika komitmen kerja guru tinggi, maka produktivitas lembaga sekolah akan tinggi pula atau jika pengawasan dilakukan dengan baik (positif), maka kebocoran anggaran akan berkurang (negatif). 


\section{c. Hipotesis}

Karena hipotesis merupakan jawaban sementara terhadap rumusan masalah penelitian yang diajukan, maka titik tolak untuk merumuskan hipotesis adalah rumusan masalah dan kerangka berpikir. Misalnya rumusan masalah adakah perbedaan kinerja sekolah antara sekolah yang menggunakan teknologi tinggidan rendah?. Maka hipotesisnya berbunyi terdapat perbedaan kinerja yang signifikan antara sekolah A dan B, atau kinerja sekolah A lebih tinggi bila dibandingkan dengan sekolah $\mathrm{B}$.

\section{PROSEDUR PENELITIAN}

a. Metode Penelitian

Untuk menjawab rumusan masalah dan menguji hipotesis, diperlukan metode penelitian. Untuk itu pada bagian ini perlu ditetapkan metode apa yang akan digunakan, apakah metode survey atau eskperimen.

b. Populasi dan Sampel

Dalam penelitian perlu dijelaskan populasi dan sampel yang dapat digunakan sebagai sumber data. Bila hasil penelitian akan digeneralisasikan (kesimpulan data sampel yang dapat diberlakukan untuk populasi) maka sampel yang digunakan sebagai sumber data harus representatif dapat dilakukan dengan cara mengambil sampel dari populasi secara random sampai jumlah tertentu. Lihat teknik pengambilan sampel.

c. Instrumen Penelitian

Penelitian yang bertujuan untuk mengukur suatu gejala akan menggunakan instrumen penelitian. Jumlah instrumen yang akan digunakan tergantung pada variabel yang diteliti. Bila variabel yang diteliti jumlahnya lima, maka akan menggunakan lima instrumen. Dalam hal ini perlu dikemukakan instrumen apa saja yang akan digunakan untuk penelitian, skala pengukuran yang ada pada setiap jenis instrumen (Likert, dll), prosedur pengujian validitas dan reliabilitas instrumen.

d. Teknik Pengumpulan Data

Yang diperlukan disini adalah teknik pengumpulan data mana yang paling tepat, sehingga betul-betul didapat data yang valid dan reliabel. Jangan semua teknik pengumpulan data (angket, observasi, wawancara) dicantumkan kalau sekiranya dapat dilaksanakan. Selain itu konsekuensi dari mencantumkan ketiga teknik pengumpulan data 
itu adalah setiap teknik pengumpulan data yang dicantumkan harus sesuai datanya. Memang untuk mendapatkan data yang lengkap dan obyektif penggunaan berbagai teknik sangat diperlukan, tetapi bila satu teknik dipandang mencukupi maka teknik yang lain bila digunakan akan menjadi tidak efektif.

e. Teknik Analisis Data

Untuk penelitian dengan pendekatan kuantitatif, maka teknik analisis data ini berkaitan dengan perhitungan untuk menjawab rumusan masalah den pengujian hipotesis yang diajukan. Bentuk yang digunakan. (lihat bab teknik analisis data). Jadi sejak membuat rancangan, maka teknik analisis data ini telah ditentukan. Bila peneliti tidak membuat hipotesis, maka rumusan masalah penelitian itulah yang perlu dijawab. Tetapi jika rumusan masalah itu dijawab, maka sulit membuat generalisasi, sehingga kesimpulan yang dihasilkan hanay berlaku untuk sampel yang digunakan, tidak dapat berlaku untuk populasi.

\section{ORGANISASI DAN JADWAL PENELITIAN}

a. Organisasi Penelitian

Bila penelitian yang dilaksanakan oleh tim/kelompok maka diperlukan adanya organisasi pelaksana penelitian, minimal ada ketua yang bertanggung jawab dan anggota, sebagai pembantu ketua.

b. Jadwal Penelitian

Setiap rancangan penelitian perlu dilengkapi dengan jadwal kegiatan yang akan dilaksanakan. Dalam jadwal berisi kegiatan apa saja yang akan dilakukan, dan berapa lama akan dilakukan. Contoh jadwal penelitian dibawah ini.

Tabel 10.1. Jadwal penelitian Kualitatif

\begin{tabular}{|c|c|c|c|c|c|c|c|c|c|c|c|c|c|}
\hline \multirow[t]{2}{*}{ No } & \multirow[t]{2}{*}{ Kegiatan } & \multicolumn{12}{|c|}{ Minggu Ke } \\
\hline & & 1 & 2 & 3 & 4 & 5 & 6 & 7 & 8 & 9 & 10 & 11 & 12 \\
\hline 1. & $\begin{array}{l}\text { Penyusunan } \\
\text { Proposal }\end{array}$ & & & & & & & & & & & & \\
\hline 2. & $\begin{array}{l}\text { Penyusunan } \\
\text { Instrumen }\end{array}$ & & & & & & & & & & & & \\
\hline 3. & $\begin{array}{l}\text { Seminar proposal } \\
\text { dan instrumen } \\
\text { penelitian }\end{array}$ & & & & & & & & & & & & \\
\hline 4. & Pengujian & & & & & & & & & & & & \\
\hline
\end{tabular}




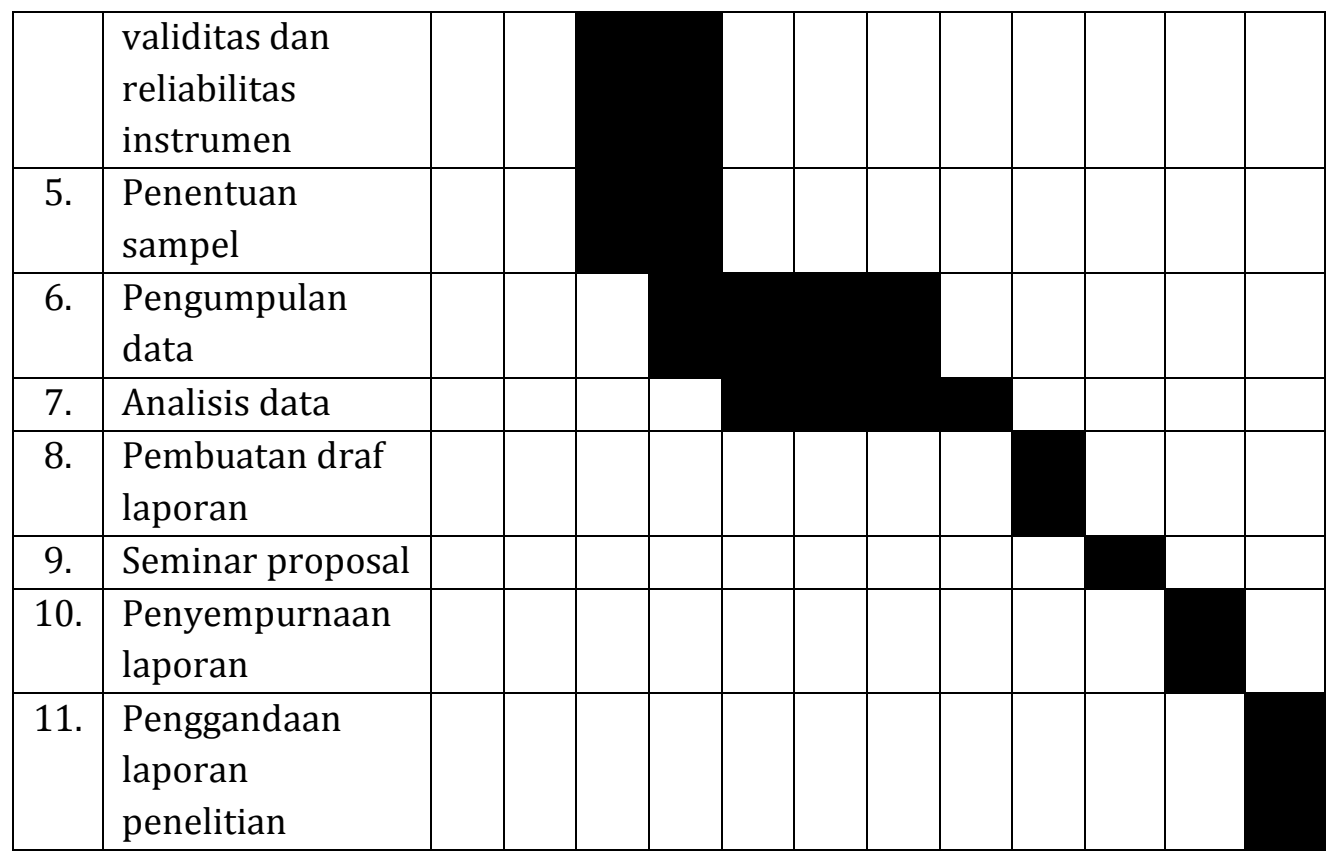

\section{BIAYA YANG DIPERLUKAN}

Biaya merupakan hal yang sangat penting dalam penelitian. Jumlah biaya yang diperlukan tergantung pada tingkat profesionalisme tenaga peneliti dan pendukungnya, tingkat resiko kegiatan dilakukan, jarak tempat penelitian dengan tempat tinggal peneliti, serta lamanya penelitian dilakukan. Biaya penelitian pada umumnya $60 \%$ digunakan untuk tenaga, dan $40 \%$ untuk penunjang seperti bahan, alat, transport, sewa alat-alat komputer. Semua biaya yang dibutuhkan perlu diuraikan secara rinci.

\section{B. PROPOSAL PENELITIAN KUALITATIF}

Dalam penelitian kuantitatif, karena permasalahan yang diteliti sudah jelas, realitas dianggap tunggal, tetap, teramati, pola pikir deduktif, maka proposal penelitian kuantitatif dipandang sebagai blue print yang harus digunakan sebagai pedoman baku untuk melaksanakan dan mengendalikan penelitian. Sedangkan dalam pendekatan kualitatif yang berpandangan bahwa, realitas dipandang sesuatu holistik, kompleks, dinamis, penuh makna, dan pola pikir induktif. Sehingga permasalahan belum jelas, maka proposal penelitian kualitatif yang dibuat masih bersifat sementara, dan akan berkembang setelah peneliti memasuki obyek penelitian/situasi sosial. Oleh karena itu proposal penelitian kualitatif diibaratkan oleh Bogdan seperti seseorang yang akan 
merencanakan piknik. Yang direncanakan dalam piknik adalah tempat-tempat baru yang akan dikunjungi, dan apa yang ingin diketahui lebih dalam dari tempat tersebut, akan tergantung pada situasi setelah seseorang berada di tempat piknik tersebut. Hal ini berarti proposal penelitian kualitatif berisi garis-garis besar rencana yang mungkin akan dilakukan. Jadi perbedaan utama antara proposal yang menggunakan pendekatan kuantitatif dan kualitatif adalah terletak pada, yang kuantitatif proposalnya spesifik dan sudah baku, dan yang kualitatif masih bersifat umum dan sementara.

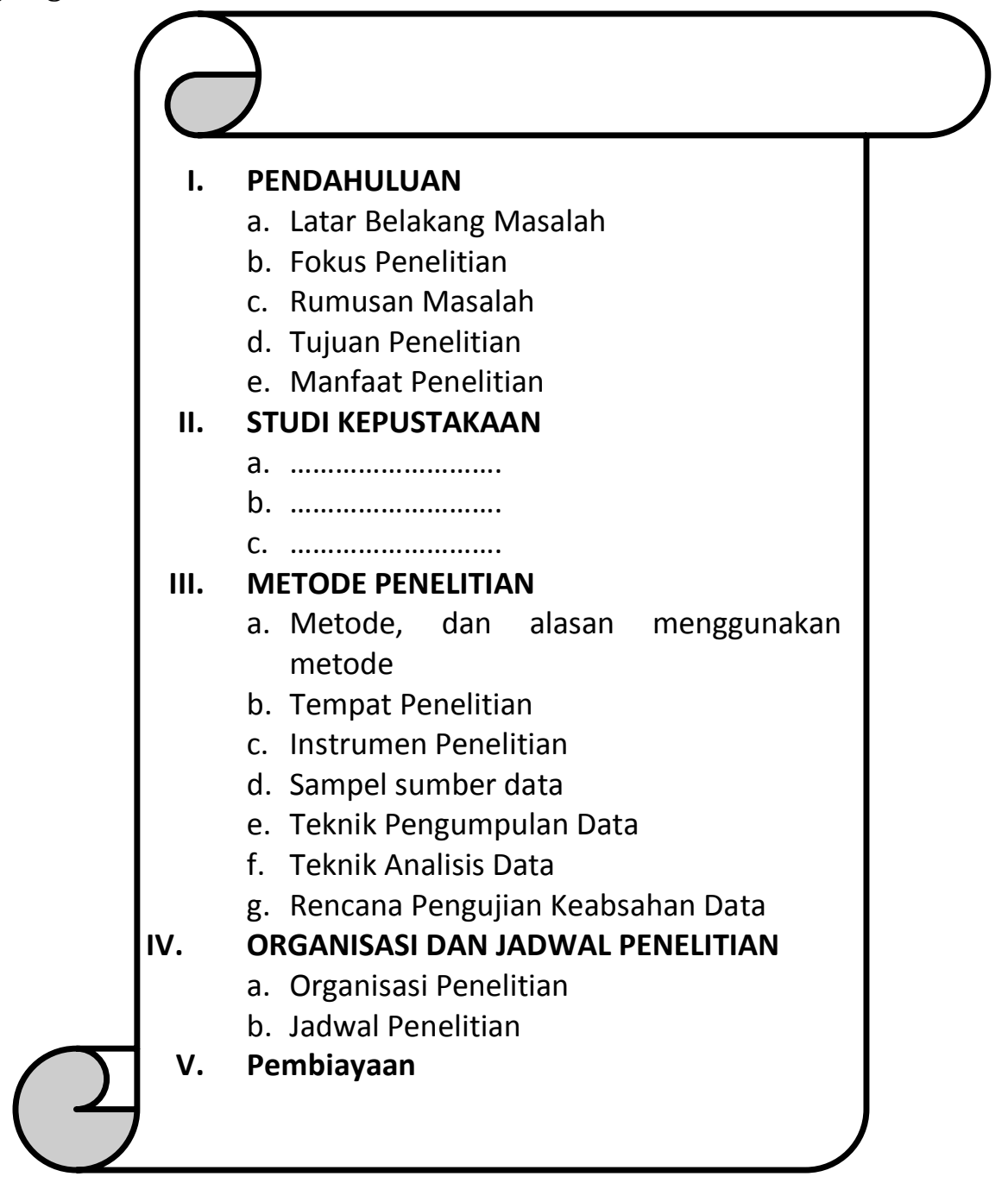

Gambar 10. 3. Sistematika proposal penelitian Kualitatif 


\section{PENDAHULUAN}

\section{a. Latar Belakang Masalah}

Walaupun dalam penelitian kualitatif masalah ini bersifat sementara, namun perlu dikemukakan dalam proposal penelitian. Masalah merupakan penyimpangan antara yang diharapkan dengan yang terjadi, penyimpangan antara teori dengan praktek, penyimpangan antara aturan dengan pelaksanaan, penyimpangan antara tujuan dengan hasil yang dicapai, dan penyimpangan antara pengalaman masa lampau yang terjadi. Setiap masalah pasti ada yang melatarbelakangi. Mobil parkir di tengah jalan akan menjadi masalah karena jalan dipakai untuk lalu lintas, tetapi apabila jalan tersebut sudah merupakan jalan yang mati/ tidak dipakai, maka tidak akan menjadi masalah. Kualitas pelayanan yang rendah akan menjadi masalah, karena pemerintah bertuga melayani masyarakat. Mobil mogok menjadi masalah karena mobil direncanakan untuk berpergian. Sewaktu kuliah bisa tidur, menjadi masalah karena yang diharapkan sewaktu kuliah tidak tidur, sebaiknya tidak bisa tidur akan menjadi masalah jika sudah waktunya direncanakan untuk tidur.

Dalam latar belakang masalah ini perlu dikemukakan gambaran keadaan yang sedang terjadi selanjutnya dikaitkan dengan peraturan/kebijakan, perencanaan, tujuan, teori, pengalaman, sehingga terlihat adanya kesenjangan yang merupakan masalah. Masalah ini perlu dikemukakan dalam bentuk data. Misalnya kegagalan transmigrasi menjadi masalah, maka perlu ditunjukan beberapa orang yang gagal dari tahun ke tahun. Kualitas pelayanan yang rendah menjadi masalah, maka perlu ditunjukan perilaku yang tidak simpatik yang melayani, dan keluhan atau pengaduan dari pihak yang dilayani.

Masalah yang dikemukakan dalam bentuk data, bisa diperoleh dari studi pendahuluan, dokumentasi laporan penelitian, atau pernyataan orang-orang yang dianggap kredibel dalam media baik media cetak maupun elektronika.

Penelitian juga tidak harus berangkat dari masalah, tetapi dari potensi. Potensi tersebut dapat berkembang menjadi masalah karena potensi tersebut tidak dapat didayagunakan. Sebagai contoh, pada tempat tertentu terdapat sumber minyak, tetapi kita tidak dapat mengeksploitasinya, maka sumber minyak itu bisa menjadi masalah. 
Setelah masalah yang dikemukakan belum dapat diatasi, dan mungkin ada potensi yang belum dapat didayagunakan, maka perlu dilakukan penelitian. Jadi dalam latar belakang masalah ini intinya berisi tentang jawaban atas pertanyaan, mengapa perlu dilakukan panelitian.

\section{b. Fokus Penelitian}

Pada penelitian kuantitatif fokus penelitian ini merupakan batasan masalah. Karena adanya keterbatasan, baik tenaga, dana, waktu sehingga hasil penelitian lebih terfokus, maka peneliti tidak akan melakukan penelitian terhadap keseluruhan yang ada pada obyek atau situasi sosial tertentu, tetapi perlu menentukan fokus. Dalam penelitian tentang pelayanan rumah sakit misalnya, maka peneliti akan memfokuskan pada prosedur pelayanan, kualitas pelayanan yang diberikan oleh dokter, perawat, petugas makanan, keamanan dan lingkungan. Contoh lain pada penelitian pendidikan akan memfokuskan pada interaksi guru dan siswa di kelas. Penelitian tentang sumber daya manusia (SDM), peneliti dapat memfokuskan pada sistem pengkajian dan kinerja pegawai.

Penentuan fokus pada penelitian kualitatif berdasarkan hasil studi pendahuluan, pengalaman, referensi, dan disarankan oleh pembimbing atau orang yang dipandang ahli. Fokus dalam penelitian ini juga masih bersifat sementara dan akan berkembang setelah peneliti turun ke lapangan.

\section{c. Rumusan Masalah}

Berdasarkan latar belakang masalah dan fokus penelitian tersebut, selanjutnya dibuat rumusan masalah. Rumusan masalah merupakan pertanyaan penelitian, yang jawabannya dicarikan melalui penelitian. Rumusan masalah ini merupkan panduan awal bagi peneliti untuk penjelajahan pada obyek yang diteliti. Naum bila rumusan masalah ini tidak sesuai dengan kondisi obyek penelitian, maka peneliti perlu mengganti rumusan masalah penelitiannya.

\section{d. Tujuan Penelitian}

Secara umum tujuan penelitian adalah untuk menemukan, mengembangkan, dan membuktikan pengetahuan. Sedangkan secara khusus tujuan penelitian kualitatif adalah untuk menemukan. Menemukan berarti sebelumnya belum pernah ada atau belum diketahui. Dengan metode pendekatan kualitatif maka peneliti dapat menemukan pemahaman luas dan mendalam terhadap situasi sosial 
yang kompleks, memahami interaksi dalam situasi sosial tersebut sehingga dapat ditemukan hipotesis, pola hubungan yang akhirnya dapat dikembangkan menjadi teori.

Tujuan penelitian dalam proposal kualitatif juga masih bersifat sementara, dan akan berkembang setelah peneliti berada di lapangan. Dalam proposal, tujuan penelitian terkait dengan rumusan masalah, yaitu untuk mengetahui segala sesuatu setelah rumusan masalah itu terjawab melalui pengumpulan data. Misalnya diketahui rumusan masalah bagaimanakah pemahaman orang-orang yang ada dalam organisasi itu tentang arti dan makna manajemen? Maka tujuan penelitian adalah untuk mengetahui pemahaman orang-orang yang ada dalam organisasi itu tentang arti dan makna manajemen.

\section{e. Manfaat Penelitian}

Setiap penlitian diharapkan memiliki manfaat. Manfaat tersebut bisa bersifat teoritis, dan praktis. Untuk penelitian kualitatif, manfaat penelitian lebih bersifat teoritis, yaitu pengembangan ilmu, namun tidak menolak manfaat praktisnya untuk memecahkan masalah. Bila peneliti kualitatif dapat menemukan teori, maka akan berguna untuk menjelaskan, memprediksikan, dan mengendalikan suatu gejala.

\section{STUDI KEPUSTAKAAN}

Studi kepustakaan berkaitan dengan kajian teoritis dan referensi lain terkandung dengan nilai, budaya, dan norma yang berkembang pada situasi sosial yang diteliti.

Terdapat tiga kriteria terhadap teori yang digunakan sebagai landasan dalam penelitian, yaitu relevansi, kemutakhiran, dan keaslian. Relevansi berarti teori yang dikemukakan sesuai dengan permasalahan yang diteliti. Misalnya masalah yang diteliti adalah kepemimpinan, bukan teori sikap atau motivasi. Kemutakhiran berarti terkait dengan kebaruan teori atau referensi yang digunakan. Pada umumnya referensi yang sudah lebih dari lima tahun diterbitkan dianggap kurang mutakhir. Penggunaan jurnal atau internet sebagai referensi untuk mengemukakan landasan teori lebih diutamakan. Keaslian terkait dengan keaslian sumber, dengan maksud supaya peneliti menggunakan sumber aslinya dalam mengemukakan teori. Diharapkan peneliti mengutip dari sumber aslinya dan hindari pengutipan dari kutipan orang lain.

Beberapa teori yang dikemukakakn dalam proposal, akan sangat tergantung pada fokus penelitian yang ditetapkan oleh peneliti. Makin 
banyak fokus penelitian yang ditetapkan maka akan semakin banyak teori yang perlu dikemukakan.

Dengan dikemukakan landasan teori dan nilai-nilai budaya yang ada pada konteks sosial yang diteliti, maka hal ini merupakan indikator bagi peneliti, apakah peneliti memiliki wawasan yang luas atau tidak terhadap situasi sosial yang diteliti. Validasi awal bagi peneliti kualitatif adalah seberapa jauh kemampuan peneliti mendeskripsikan teori-teori yang terkait dengan bidang dan konteks sosial yang diteliti.

Dalam landasan teori ini perlu dikemukakan definisi setiap fokus yang akan diteliti, ruang lingkup keluasan serta kedalamannya. Dalam definisi perlu dikemukakan definisi-definisi yang sejalan maupun yang tidak sejalan. Jadi kdikontraskan. Dengan demikian maka landasan teori yang dikemukakan semakin kuat.

Dalam penelitian kualitatif, teori yang dikemukakan bersifat sementara, dan akan berkembang atau berubah setelah peneliti berada di lapangan. Selanjutnya dalam landasan teori, tidak perlu dibuat kerangka berpikir sebagai dasar untuk perumusan hipotesis, karena dalam penelitian kualitatif tidak akan menguji hipotesis, tetapi justru menemukan hipotesis.

\section{METODE PENELITIAN}

Komponen dalam metode penelitian kualitatif adalah: alasan menggunakan metode kualitatif, tempat penelitian, instrumen penelitian, sampel sumber data penelitian, teknik penguumpulan data, teknik analisis data dan rencana pengujian keabsahan data.

\section{a. Metode, dan Alasan Menggunakan Metode}

Dalam hal ini perlu dikemukakan, mengapa metode penelitian yang digunakan adalah metode kualitatif. Pada umumnya alasan menggunakan metode kualitatif karena, permasalahan belum jelas, holistik, kompleks, dinamis dan penuh makna sehingga tidak mungkin data pada situasi sosial tersebut dijaring dengan metode penelitian kuantitatif dengan instrumen seperti tes, kuesioner, pedoman wawancara. Selain itu peneliti bermaksud memasahami situasi sosial secara mendalam, menemukan pola, hipotesis, dan teori.

\section{b. Tempat Penelitian}

Dalam hal ini perlu dikemukakan dimana situasi sosial tersebut akan diteliti. Misalnya di sekolah, di perusahaan, di lembaga pemerintah, di jalan, dan lain-lain. 


\section{c. Instrumen Penelitian}

Pada penelitian kualitatif yang menjadi instrumen utama adalah peneliti sendiri atau anggota tim peneliti. Untuk itu perlu diketahui siapa yang akan menjadi instrumen penelitian, atau mungkin setelah permasalahannya dan fokus jelas peneliti akan menggunakan instrumen. Instrumen yang akan digunakan perlu dilampirkan pada bagian ini.

\section{d. Sampel Sumber Data}

Dalam penelitian kualitatif, sampel sumber data dipilih secara purposive dan bersifat snowball sampling. Penentuan sampel sumber data pada proposal masih bersifat sementara, dan akan berkembang kemudian seteleh peneliti di lapangan. Sampel sumber data pada tahap awal memasuki lapangan dipilih orang yang mewakili kekuasaan dan otoritas pada situasi sosial atau obyek yang diteliti, sehingga mampu membukakan pintu kemana saja peneliti akan melakukan pengumpulan data.

Sanafiah Faisal (1990) dengan mengutip pendapat Spradley menyatakan bahwa situasi sosial yang didalamnya menjadi semacam muara dari banyak domain lainnya. Sampel sebagai sumber data atau informan sebaiknya ynag memenuhi kriteria sebagai berikut:

1) Mereka yang menguasai atau memahami sesuatu melalui proses enkulturasi, sehingga sesuatu itu bukan sekedar diketahui, tetapi juga dihayatinya.

2) Mereka yang tergolong sedang berkecimpung atau terlibat pada kegiatan yang tengah diteliti.

3) Mereka yang mempunyai waktu yang memadai untuk diminta informasi.

4) Mereka yang tidak cenderung menyampaikan informasi hasil kemasannya sendiri.

5) Mereka yang pada mulanya tergolong cukup asing dengan peneliti sehingga lebih bersemangat untuk dijadikan semacam guru atau narasumber.

Siapa yang dijadikan sampe sumber data, dan beberapa jumlahnya dapat diketahui setelah penelitian selesai. Jadi tidak dapat disiapkan sejak awal atau dalam proposal.

\section{e. Teknik Pengumpulan Data}

Penelitian kualitatif pada bagian teknik pengumpulan data yang utama adalah observasi participant, wawancara mendalam, studi dokumentasi, dan gabungan kegiatannya atau triangulasi data. 
Pengumpulan data dengan observasi maka perlu diperhatikan apa yang diobservasi, dan jikalau wawancara kepada siapa akan melakukan wawancara.

\section{f. Teknik Analisis Data}

Teknik analisis data pada penelitian kualitatif lebih banyak data dianalisis cara bersamaan dengan waktu pengumpulan data. Tahapan dalam penelitian kualitatif adalah tahap memasuki lapangan dengan grand tour dan minitour question, analisis data dilakukan dengan analisis taksonomi. Selanjutnya pada tahap selection, pertanyaan yang digunakan adalah pertanyaan struktural, analisis data dengan analisis komponensial. Setelah analisis komponensial dilanjutkan analisis tema.

Jadi analisis data kualitatif menurut Miles and Huberman dilakukan secara interaktif melalui proses data reduction, data display, dan verification. Sedangkan menurut Spradley dilakukan secara berurutan, melalui proses analisis domain, taksonomi, komponensial, dan tema budaya.

\section{g. Rencana Pengujian Keabsahan Data}

Pada proposal dengan manggunakan pendekatan penelitian kualitatif perlu dikemukakan rencana uji keabsahan data. Uji ini meliputi uji kredibilitas data (validitas internal), uji dependabilitas (reliabilitas) data, uji transferabilitas (validitas eksternal/generalisasi), dan uji konfirmabilitas (obyektivitas). Namun yang utama adalah uji kredibilitas data. Uji ini dilakukan dengan perpanjangan pengamatan, meningkatkan ketekunan, triangulasi, diskusi dengan teman sejawat, member check, dan analisis kasus negatif.

\section{ORGANISASI DAN JADWAL PENELITIAN}

\section{a. Organisasi Penelitian}

Organisasi penelitian ini perlu dikemukakan, bila penelitian dilakukan oleh tim. Dalam organisasi peneliti, pengumpul data, bendahara, tenaga administrasi. Masing-masing perlu dikemukakan uarain tugas dan waktu yang tersedia.

\section{b. Jadwal Penelitian}

Umumnya peneltia dengan pendekatan kualitatif menggunakan waktu yang relatif lama antara $6-12$ bulan. Untuk itu perlu direncanakan jadwal pelaksanaan penelitian. Jadwal penelitian berisi aktivitas yang dilakukan dan kapan akan dilakukan. Berikut ini diberikan contoh rencana jadwal penelitian kualitatif. Berikut ini akan diberikan contoh rencana jadwal penelitian kualitatif. 


\section{Pembiayaan}

Biaya merupak hal yang sangat penting dalam penelitian. Jumlah biaya yang diperlukan tergantung pada tingkat profesionalisme tenaga peneliti dan pendukungnya, tingkat resiko kegiatan dilakukan, jarak tempat penelitian dengan tempat tinggal peneliti, serta lamanya penelitian dilakukan. Biaya penelitian pada umunya $60 \%$ digunakan untuk tenaga, dan $40 \%$ untuk penunjang seperti bahan, alat, transport, sewa alat-alat komputer. Semua biaya yang dibutuhkan perlu diuraikan secara rinci.

Tabel 10.2. Jadwal penelitian Kuantitatif

\begin{tabular}{|l|l|l|l|l|l|l|l|l|l|}
\hline No & \multicolumn{1}{|c|}{ Kegiatan } & \multicolumn{7}{c|}{ Bulan ke } \\
\cline { 3 - 9 } & & $\mathbf{1}$ & $\mathbf{2}$ & $\mathbf{3}$ & $\mathbf{4}$ & $\mathbf{5}$ & $\mathbf{6}$ & $\mathbf{7}$ & $\mathbf{8}$ \\
\hline 1. & Penyusunan proposal & & & & & & & & \\
\hline 2. & Diskusi proposal & & & & & & & \\
\hline 3. & $\begin{array}{l}\text { Memasuki lapangan, grand tour, } \\
\text { dan minitour question, analisis } \\
\text { domain }\end{array}$ & & & & & & & \\
\hline 4. & $\begin{array}{l}\text { Menentukan fokus, minitour } \\
\text { question, analisis taksonomoi }\end{array}$ & & & & & & & & \\
\hline 5. & $\begin{array}{l}\text { Tahap selection, structural } \\
\text { question, analisis komponensial }\end{array}$ & & & & & & & & \\
\hline 6. & Menentukan tema, analisis tema & & & & & & & & \\
\hline 7. & Uji keabsahan data & & & & & & & & \\
\hline 8. & Membuat laporan penelitian & & & & & & & & \\
\hline 9. & Diskusi draf laporan & & & & & & & & \\
\hline 10. & Penyempurnaan laporan & & & & & & & & \\
\hline
\end{tabular}

\section{KASUS \\ HASIL OBSERVASI}

Observasi tentang pembelajaran matematika di SLB Autisma YPPA Padang kami laksanakan pada hari Sabtu, 04 Februari 2017. SLB YPPA Padang merupakan sekolah yang menampung anak autis untuk diterapi maupun pengembangan akademik serta minat bakat anak. Gangguan autistik ditandai dengan tiga gejala utama yaitu gangguan interakasi sosial, gangguan komunikasi, dan perilaku yang stereotipik. autisme ialah anak yang mengalami gangguan berkomunikasi dan berinteraksi sosial serta mengalami gangguan sensori, pola bermain, dan emosi. Adapun pelaksanaan Observasi tersebut 
kami laksanakan dengan pengamatan selama kegiatan proses pembelajaran, tanya jawab dengan guru pengampu mata pelajaran Matematika, dan dikuatkan dengan dokumentasi tentang proses pembelajaran yang kami Observasi. Secara prosedural pelaksanaan Observasi yang kami lakukan dengan langkah-langkah sebagai berikut:

\section{Kurikulum yang Berlaku di SLB Autisma YPPA Padang}

SLB YPPA Padang menggunakan kurikum 2013, dimana pelaksanaan proses pembelajaran salah satunya mencakup aspek pembelajaran matematika. Proses pembelajaran tidak menggunakan silabus, dimana bahan materi untuk membuat Rencana Pelaksanaan Pembelajaran (RPP) diambil dari buku guru dan buku siswa yang telah disediakan oleh sekolah.

Pelaksanaan pembelajaran matematika telah terangkum secara menyeluruh dalam RPP yang telah dibuat oleh guru namun dalam pelaksanaannya RRP tersebut dimodifikasi sesuai dengan kemampuan dan kebutuhan siswa yang bersangkutan.

\section{Beban Belajar Kurikulum 2013}

Beban belajar yang diberikan oleh guru ke siswa bertambah sedangkan menurut guru tidak sesuai dengan kemampuan anak autis yang lebih memerlukan kemampuan vokasional.

Proses pembelajaran yang dikembangkan menghendaki kesabaran guru dalam mendidik siswa sehingga mereka menjadi tahu, mampu dan mau belajar dan menerapkan apa yang sudah mereka pelajari di lingkungan sekolah dan masyarakat sekitarnya.

\section{Penerapan Kurikulum 2013}

Kurikulum 2013 akan terealisasi jika semua unsur melaksanakanya. Unsur di sini mempunya arti luas, unsur yang dimaksud adalah berbagai lapisan. Dimulai dari pemerintah tentang penerapan kurikulum ini dan sarana prasarana yang harus diberikan kepada setiap sekolah. Jika, sarana dan prasarana telah disiapkan maka guru-guru di sekolah harus siap dengan penerapan kurikulum 2013 ini. Diusianya mereka pasti lebih menginginkan cara belajar yang nyaman, menyenangkan, dan tidak membosankan, misalnya penerapan belajar menggunakan permainan sehingga membuat siswa aktif.

Selain pemeritah dan guru-guru yang terlibat dalam penerapan kurikulum 2013 ini, masyarakat dan keluarga merupakan peran penting untuk menerapkan inti dari kurikulum 2013. Misalkan dilingkungan keluarga ibu dan ayah harus bisa memantau dan menerapkan inti dari 
kurikulum 2013, contoh kecil menyuruh anaknya untuk beribadah sholat dan bersosialisai dengan teman-teman dekatnya. Lingkungan masyarakat juga sangat berpengaruh besar dalam hal ini, karena masyarakat bisa mempengaruhi pola hidup anak didik itu, misalkan dilingkungannya jarang sekali anak yang mengaji atau belajar dengan sendirinya anak itu akan melihat teman-temanya bermain dan maka dengan keluguan atau kepolosan anak pasti tertarik untuk bermain. Tetapi akan positif jika permainanya beredukasi dilingkungan masyarakat tersebut. Jadi kurikulum 2013 akan terealisasi jika semua unsur saling mendukung.

\section{Persiapan kurikulum 2013}

Di SLB Autis YPPA guru-guru harus siap karena untuk membuktikan keprofesionalan mereka. Persiapan yang dilakukan oleh guru-guru adalah mulai mempelajari dan memahami kurikulum 2013 diberbagai media sosial dan mulai mengkajinya, tetapi ada beberapa guru yang kebingungan untuk menerapkan kurikulum 2013, karena kurikulum 2013 mengharuskan siswanya sudah bisa membaca dan menulis setelah mendaftar sekolah maka penerapanya harus seperti apa karena tema yang diberikan sudah ditetapkan, maka solusi lain terlebih dahulu dipentingkan kemampuan vokasional. Ini yang jadi permasalahan di sekolah luar biasa dalam penerapan kurikulum 2013. Guru sangatlah berperan penting di SLB karena mereka harus banyak memberikan materi dasar supaya di kelas-kelas berikutnya mengikuti, tetapi disisi lain juga disiapkan khusus pelatih yang mengisi kelas itu untuk meningkatkan kemampuan siswa sesuai bakat minat mereka.

\section{Strategi Pembelajaran}

Tidak jauh beda dengan metode pada KTSP, SLB Autisme YPPA Padang menggunakan metode pembelajaran:

a. Ceramah

Ceramah adalah strategi mengajar anak autis dengan cara ceramah dengan secara pelan-pelan dan berulang-ulang. Dengan tekhnik seperti ini, anak autis diharapkan agar memahami apa yang telah guru sampaikan dan mempaktekannya dalam kehidupan sehari-harinya.

b. Menulis

Menulis adalah pelatihan yang memanfaatkan motorik anak agar dapat menunjang dan mendukung proses pemahaman anak pada pelajaran. 


\section{c. Pemantauan}

Pemantauan dilakukan oleh guru untuk memantau anak dalam proses pembelajaran. Bila anak melakukan kesalahan, dapat dikoreksi dan apabila benar maka diberi pujian agar anak

\section{Media} lebih bersemangat dalam belajar.

Alat atau media yang digunakan oleh guru dalam mengajar sangat bervariasi sesuai dengan kebutuhan anak dan materi pada RPP sehingga proses belajar mengajar lebih kondusif. Media yang digunakan diantaranya: media gambar, puzzle, benda asli, maupun benda tiruan.

Berdasarkan hasil observasi di atas diskusikanlah dengan kelompok masing-masing terkait perancangan proposal penelitiannya.

\section{RANGKUMAN}

Rancangan atau proposal penelitian merupakan pedoman yang berisi langkah-langkah yang akan diikuti oleh peneliti untuk melakukan penelitiannya. Dalam menyusun rancangan penelitian, perlu diantisipasi tentang berbagai sumber yang dapat digunakan untuk mendukung dan yang menghambat terlaksananya penelitian. Penelitian dilakukan berangkat dari adanya suatu permasalahan. Dalam penelitian kuantitatif, karena permasalahan yang diteliti sudah jelas, realitas dianggap tunggal, tetap, teramati, pola pikir deduktif, maka proposal penelitian kuantitatif dipandang sebagai blue print yang harus digunakan sebagai pedoman baku untuk melaksanakan dan mengendalikan penelitian. Sedangkan dalam pendekatan kualitatif yang berpandangan bahwa, realitas dipandang sesuatu holistik, kompleks, dinamis, penuh makna, dan pola pikir induktif. Sehingga permasalahan belum jelas, maka proposal penelitian kualitatif yang dibuat masih bersifat sementara, dan akan berkembang setelah peneliti memasuki obyek penelitian/situasi sosial.

Proposal penelitian paling tidak berisi empat komponen utama, yaitu permasalahan, landasan teori dan pengajuan hipotesis, metode penelitian, organisasi dan jadwal penelitian. Komponen dan sistematika dalam proposal dengan menggunakan pendekatan kuantitatif tidak berbeda dengan kualitatif. Semua komponen dalam proposal penelitian kuantitatif sudah merupakan hal yang baku, sedangkan dalam proposal penelitian kualitatif bersifat sementara 
dan akan berkembang setelah peneliti berada di lapangan. Setelah di lapangan mungkin masalah, fokus, teori, teknik pengumpulan data, analisis data, bahkan judul penelitian bisa berubah.

\section{TUGAS}

Produk akhir yang diharapkan untuk mata kuliah Metodologi Penelitian Pendidikan Matematika adalah Proposal Penelitian. Mahasiswa telah memahami bagaimana merumuskan masalah penelitian berdasarkan fakta yang terjadi sampai dengan bab teknik analisi data. Dengan demikian, mahasiswa diharapkan menyusun proposal penelitian berdasarkan masalah yang ditemukan pada waktu observasi pemebelajaran matematika di sekolah. 


\section{DAFTAR PUSTAKA}

Akker, J. van den, Gravemeijer, K., McKenney, S., \& Nieveen, N. (2006). INTRODUCING EDUCATIONAL DESIGN RESEARCH. London: Routledge Taylor and Francis Group.

Arikunto, S. (2010). Prosedur Penelitian: Suatu Pendekatan Praktek. Jakarta: Rineka Cipta.

Bennett, N., Borg, W. R., \& Gall, M. D. (1984). Educational Research: An Introduction. In British Journal of Educational Studies (Seventh Ed, Vol.

32, Issue 3). Boston: Longman. https://doi.org/10.2307/3121583

Branch, R. M. (2009). Instructional design: The ADDIE approach. Springer Science \& Business Media.

DiSessa, A. A., \& Cobb, P. (2014). Ontological Innovation and the Role of Theory in Design Experiments. THE JOURNAL OF THE LEARNING SCIENC, 13(2), 77-104.

Farman, F., \& Yusryanto, Y. (2018). PENGEMBANGAN DESAIN PEMBELAJARAN BERBASIS PROBLEM POSING DALAM UPAYA MENINGKATKAN KEMAMPUAN PENALARAN KONSEP LINGKARAN PADA SISWA SMP KELAS VIII. Jurnal Karya Pendidikan Matematika, 5(2), 20. https://doi.org/10.26714/jkpm.5.2.2018.20-27

Fauzan, A. (2002). APPLYING REALISTIC MATHEMATICS EDUCATION (RME) IN TEACHING GEOMETRY IN INDONESIAN PRIMARY SCHOOLS. Enschede: University of Twente.

Hasnunidah, N. (2017). Metodologi Penelitian Pendidikan. Media Akademi. Knipples, \& Josephina, M.-C. P. (2002). Coping with the abstract and complex nature of genetics in biology education. Utrecht, The Netherlands: University of Utrecht.

Lutvaidah, U. (2016). Pengaruh Metode dan Pendekatan Pembelajaran terhadap Penguasaan Konsep Matematika. Formatif: Jurnal Ilmiah Pendidikan MIPA. https://doi.org/10.30998/formatif.v5i3.653

Mangelep, N. O. (2011). KONTEKS MEMBAGI ROTI DALAM MEMPELAJARI

LUAS SEGITIGA. IMPoME 2011 Sriwijaya UNiversity.

Margono, S. (2004). Metodologi Penelitian Pendidikan. Jakarta : Rineka Cipta. Muhammad, A. (1982). Penelitian Pendidikan Prosedur dan Strategi. Bandung Angkasa.

Mulyatiningsih, E. (2011). Riset Terapan Bidang Pendidikan dan Teknik (Nuryanto Apri (ed.); 1st ed.). Yogyakarta: UNY Press. http://staffnew.uny.ac.id/upload/132296045/lainlain/buku-risetterapan-apri.pdf 
Plomp, T., \& Nieveen, N. (2013). SLO: The Seminar on an Introduction to Educational Design Research. In an Introduction to Educational Design Research. The Netherlands: SLO.

Purnomo, E. A., Dalyono, B., \& Handayani, S. (2018). PENGEMBANGAN MEDIA PEMBELAJARAN BERBASIS ANDROID PADA MATA KULIAH STATISTIKA PENDIDIKAN. Jurnal Karya Pendidikan Matematika, 5(2), 117-120. https://doi.org/https://doi.org/10.26714/jkpm.5.2.2018.117-120 Putra, Y. Y., \& Vebrian, R. (2019). DESAIN PEMBELAJARAN PMRI MATERI OPERASI HITUNG BILANGANMENGGUNAKAN KONTEKS KERETAK GETAS. MATHEMA JOURNAL, 1(1), 1-14.

Putrawangsa, S. (2018). DESAIN PEMBELAJARAN Design Research sebagai Pendekatan Desain Pembelajaran (1st ed.). CV. Reka Karya Amerta (Rekarta).

PUTRAWANGSA, S., LUKITO, A., MAMIN, S., \& WIJERS, M. (2014). EDUCATIONAL DESIGN RESEARCH: DEVELOPING STUDENTS' UNDERSTANDING OF THE MULTIPLICATION STRATEGY IN AREA MEASUREMEN. Prosiding Konferensi Nasional Matematika (KNM) XVII, 633-648.

Simon, M. A. (1995). RECONSTRUCTING MATHEMATICS PEDAGOGY FROM A CONSTRUCTIVIST PERSPECTIVE. Journal for Re.;Earcl! In Mathematits Educ: tion, 26(2), 114-145.

Sohilait, E. (2018). Pengembangan Perangkat Pembelajaran Matematika pada Materi Himpunan Melalui pendekatan Pendidikan Matematika Realistik. Sohilait, E. (2019). Desain Pembelajaran Berbasis Pendekatan Pendidikan Matematika Realistik Dengan Menggunakan Masalah Kontekstual. Prosiding Seminar Nasional Pendidikan Matematika.

Sugiyono. (2009). Metode Penelitian Pendidikan Pendekatan Kuantitatif. Bandung : Alfabeta.

Sugiyono, P. D. (2017). Metode Penelitian Bisnis: Pendekatan Kuantitatif, Kualitatif, Kombinasi, dan R\&D. (25th ed.). Alfabeta Bandung. Sujarweni, V. W. (2014). Metode Penelitian: Lengkap, Praktis, dan Mudah Dipahami. Pustaka Baru Press.

Sukardi. (2003). Metodologi Penelitian Pendidikan (1st ed.). Jakarta: Bumi Aksara.

Sukmadinata, N. S. (2012). Metode Penelitian Pendidikan. PT. Remaja Rosdakarya.

Van den Akker, J. (2006). Educational Design Research. In Educational Design Research. Netherlands: Roudledge. 
https://doi.org/10.4324/9780203088364

Wahyuni, Y. (2017). IDENTIFIKASI GAYA BELAJAR (VISUAL, AUDITORIAL, KINESTETIK) MAHASISWA PENDIDIKAN MATEMATIKA UNIVERSITAS BUNG HATTA. Jurnal Penelitian Dan Pembelajaran Matematika. https://doi.org/10.30870/jppm.v10i2.2037

Warsito, W., Nuraini, Y., \& Sukirwan, S. (2019). Desain Pembelajaran Pecahan melalui Pendekatan Realistik di Kelas V. Mosharafa: Jurnal Pendidikan Matematika. https://doi.org/10.31980/mosharafa.v8i1.381

Wijaya, A. (2008). Design Research in Mathematics Education:Indonesian Traditional Games as Means to Support Second Graders' Learning of Linear Measurement. Utrecht: Utrecht University. 
A

Analisis

Anava

Asosiatif

C

D

Data

Deduktif

Deskriptif

E

efektivitas

\section{GLOSARIUM}

: penyelidikan terhadap suatu peristiwa untuk mengetahui keadaan yang sebenarnya.

: metode untuk menguji hubungan antara satu variabel dependen (terikat) dengan satu atau lebih variabel independen (bebas).

: proses yang terjadi pada bentuk interaksi sosial dan mengarah pada persatuan, kesatuan, dan dapat meningkatkan solidanitas sosial antar individu atau kelompok.

cluster sampling $\quad:$ teknik memilah, memilih dari sebuah sampel dari kelompok-kelompok dari unit yang kecil.

: kumpulan dari fakta yang dapat berupa angka, simbol ataupun tulisan yang diperoleh melalui pengamatan suatu objek.

: pendekatan yang menggunakan logika untuk menarik satu atau lebih kesimpulan berdasarkan seperangkat premis yang diberikan.

dependen : Terikat

desain pembelajaran : proses yang merumuskan dan menentukan tujuan pembelajaran, strategi, teknik, dan media agar tujuan umum tercapai

: jenis penelitian yang tujuannya untuk menyajikan gambaran lengkap mengenai setting sosial atau dimaksudkan untuk eksplorasi dan klarifikasi mengenai suatu fenomena atau kenyataan sosial, dengan jalan mendeskripsikan sejumlah variabel yang berkaitan dengan masalah dan unit yang diteliti antara fenomena yang diuji

keadaan yang menunjukkan tingkat keberhasilan atau pencapaian suatu tujuan 
empiris

eksperimen

F

fakta

$\mathrm{H}$

hipotesis

idependen

Induktif

J

jurnal

K

kepraktisan

koherensi yang diukur dengan kualitas, kuantitas dan waktu sesuai dengan yang telah direncanakan sebelumnya.

: ilmu pengatahuan yang diperoleh dari suatu penemuan, percobaan, serta juga pengamatan yang telah dilakukan.

: tindakan dan pengamatan, yang dilakukan untuk mengecek atau menyalahkan hipotesis atau mengenali hubungan sebab akibat antara gejala.

: sesuatu yang tertangkap oleh indra manusia atau data keadaan nyata yang terbukti dan telah menjadi suatu kenyataan.

: anggapan dasar adalah jawaban sementara terhadap masalah yang masih bersifat praduga karena masih harus dibuktikan kebenarannya.

: rangkaian pengamatan yang sambung menyambung, berakumulasi 'dan melahirkan teori-teori yang mampu menjelaskan dan meramalkan fenomena-fenomena

: Bebas

: metode yang digunakan dalam berpikir dengan bertolak dari hal-hal khusus ke umum.

: publikasi ilmiah yang berisi kumpulan artikel dan pada umumnya terbit secara reguler, seperti misalnya dua kali atau empat kali dalam setahun.

: tingkat bahwa pengguna (atau pakar-pakar lainnya) memperimbangkan intervensi dapat digunakan dan disukai dalam kondisi normal. : tersusunnya uraian atau pandangan sehingga 
bagian-bagiannya berkaitan satu dengan yang lain.

komparatif

konteks

kontinum

korelasi

kualitatif

kuantitatif

kuesioner

$\mathrm{L}$

Literatur

M

masalah

metodologi

0

observasi
: hal yang bersifat dapat diperbandingakan dengann sesuatu hal lainnya

: situasi yang ada hubungannya dengan suatu kejadian.

: rangkaian.

: ukuran dari seberapa dekat dua variabel berubah dalam hubungan satu sama lain.

: metode yang lebih menekankan pada aspek pemahaman secara mendalam terhadap suatu masalah daripada melihat permasalahan untuk penelitian generalisasi.

: metode yang lebih menekankan pada aspek pengukuran secara obyektif terhadap fenomena sosial.

: daftar pertanyaan yang dikirim kepada responden baik secara Iangsung maupun tidak Iangsung.

: sumber ataupun acuan yang digunakan dalam berbagai macam aktivitas di dunia pendidikan ataupun aktivitas lainnya.

: suatu pernyataan tentang keadaan yang belum sesuai dengan yang diharapkan.

: ilmu yang digunakan untuk memperoleh kebenaran menggunakan penelusuran dengan tata cara tertentu dalam menemukan kebenaran, tergantung dari realitas yang sedang dikaji. Metodologi tersusun dari caracara yang terstruktur untuk memperoleh ilmu.

: aktivitas terhadap suatu proses atau objek dengan maksud merasakan dan kemudian memahami pengetahuan dari sebuah fenomena berdasarkan pengetahuan dan 
$\mathrm{P}$

populasi

$\mathrm{R}$

S

sampel

Statistika inferensial

$\mathrm{T}$

teori

$\mathrm{U}$

ujicoba gagasan yang sudah diketahui sebelumnya, untuk mendapatkan informasi-informasi yang dibutuhkan untuk melanjutkan suatu penelitian.

: keseluruhan objek penelitian yang terdiri atas manusia, hewan, benda-benda, tumbuh, peristiwa, gejala, ataupun nilai tes sebagai sumber data yang mempunyai karakteristik tertentu dalam suatu penelitian yang dilakukan.

: pengukuran atau serangkaian alat ukur yang memiliki konsistensi bila pengukuran yang dilakukan dengan alat ukur itu dilakukan secara berulang.

: bagian dari populasi yang dipelajari dalam suatu penelitian dan hasilnya akan dianggap menjadi gambaran bagi populasi asalnya. : metode yang bisa digunakan untuk bisa menganalisis kelompok kecil dari data induknya atau sample yang diambil dari populasi sampai pada peramalan dan juga penarikan kesimpulan pada kelompok data induknya atau populasi.

: serangkaian bagian atau variabel, definisi dan dalil yang saling berhubungan yang menghadirkan sebuah pandangan sistematis mengenai fenomena dengan menentukan hubungan antarvariabel, dengan maksud menjelaskan fenomena alamiah.

: pengujian sesuatu sebelum dipakai atau dilaksanakan. 
valid

variabel
: Derajat ketepatan antara data yang sesungguhnya terjadi pada objek dengan data yang dikumpulkan oleh peneliti. 